DOE/EIA-0562(96)

Distribution Category UC-950

\title{
The Changing Structure of the Electric Power Industry: An Update
}

\author{
December 1996
}

DSTRIBUTION OF THS DOCUMENT IS UNMUIE

Energy Information Administration

Office of Coal, Nuclear, Electric and Alternate Fuels

U.S. Department of Energy

Washington, DC 20585

This report was prepared by the Energy Information Administration, the independent statistical and analytical agency within the Department of Energy. The information contained herein should not be construed as advocating or reflecting any policy position of the Department of Energy or of any other organization. 


\section{Contacts}

This report was prepared by the staff of the Coal and Electric Analysis Branch, Analysis and Systems Division, Office of Coal, Nuclear, Electric and Alternate Fuels. General information regarding this publication may be obtained from Robert M. Schnapp, Director, Analysis and Systems Division, by phone on 202/426-1211 or via Internet at rschnapp@eia.doe.gov, or Betsy O'Brien, Chief, Coal and Electric Analysis Branch, by phone on 202/426-
1180 or via Internet at bobrien@eia.doe.gov. Specific questions regarding the preparation and content of the report should be directed to Rebecca A. McNerney, project manager of the publication, by phone on 202/426-1251 or via Internet at rmcnerne@eia.doe.gov. Questions regarding specific chapters of the report should be directed as follows:
Phone

(202) 426-1251

(202) $426-1251$

(202) $426-1131$

(202) 426-1251

(202) 426-1131

(202) 426-1251

(202) 426-1257

(202) 426-1257

(202)426-1139
Internet

rmcnerne@eia.doe.gov

rmcnerne@eia.doe.gov

lspancak@eia.doe.gov

rmcnerne@eia.doe.gov

lspancak@eia.doe.gov

rmcnerne@eia.doe.gov

skanhouw@eia.doe.gov

skanhouw@eia.doe.gov

wliggett@eia.doe.gov
William D. Liggett 


\section{Preface}

Section 205(a)(2) of the Department of Energy Organization Act of 1977 (Public Law 95-91) requires the Administrator of the Energy Information Administration (EIA) to carry out a central, comprehensive, and unified energy data information program that will collect, evaluate, assemble, analyze, and disseminate data and information relevant to energy resources, reserves, production, demand, technology, and related economic and statistical information. To assist in meeting these responsibilities in the area of electric power, EIA has prepared this report, The Changing Structure of the Electric Power Industry: An Update. The purpose of this report is to provide a comprehensive overview of the structure of the U.S. electric power industry over the past 10 years, with emphasis on the major changes that have occurred, their causes, and their effects. It is intended for a wide audience, including Congress, Federal and State agencies, the electric power industry, and the general public.
The legislation that created the EIA vested the organization with an element of statutory independence. The EIA does not take positions on policy questions. The EIA's responsibility is to provide timely, high-quality information and to perform objective, credible analyses in support of deliberations by both public and private decisionmakers. Accordingly, this report does not purport to represent the policy positions of the U.S. Department of Energy or the Administration.

This report can be accessed and downloaded as a Portable Document Format (PDF) file from ELA's World Wide Web site by connecting your Web browser (i.e., Netscape, MS Internet Explorer, etc.) to EIA's Home Page at http://www.eia.doe.gov. Once connected, click on "Electric" to go to the "Electric Page." Then, move to the Publications menu and click on the publication title to begin the download process. 



\section{DISCLAIMER}

Portions of this document may be illegible in electronic image products. Images are produced from the best available original document. 


\section{DISCLAIMER}

This report was prepared as an account of work sponsored by an agency of the United States Government. Neither the United States Government nor any agency thereof, nor any of their employees, make any warranty, express or implied, or assumes any legal liability or responsibility for the accuracy, completeness, or usefulness of any information, apparatus, product, or process disclosed, or represents that its use would not infringe privately owned rights. Reference herein to any specific commercial product, process, or service by trade name, trademark, manufacturer, or otherwise does not necessarily constitute or imply its endorsement, recommendation, or favoring by the United States Government or any agency thereof. The views and opinions of authors expressed herein do not necessar. ily state or reflect those of the United States Government or any agency thereof. 


\section{Contents}

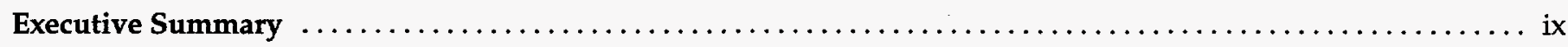

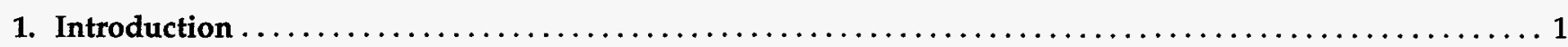

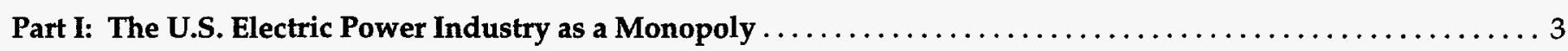

2. A Brief Historical Overview of the Electric Power Industry $\ldots \ldots \ldots \ldots \ldots \ldots \ldots \ldots \ldots \ldots \ldots$

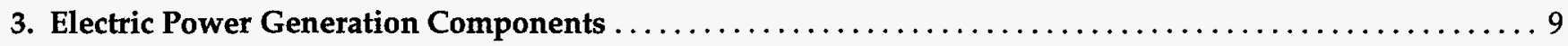

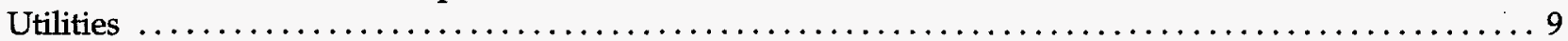

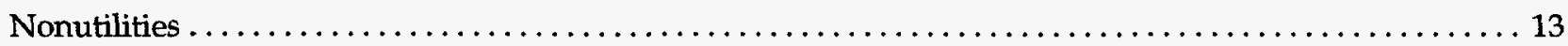

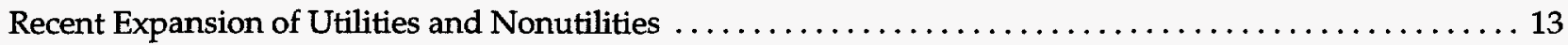

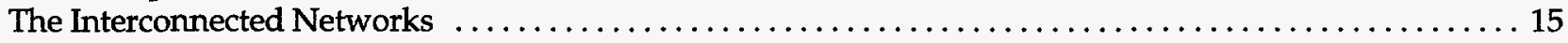

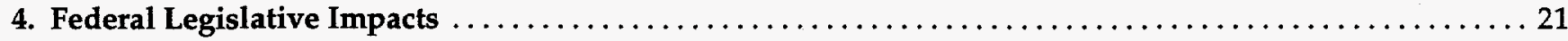

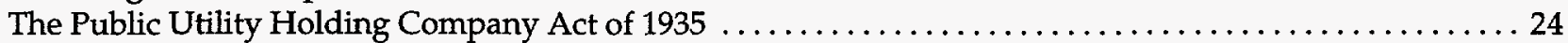

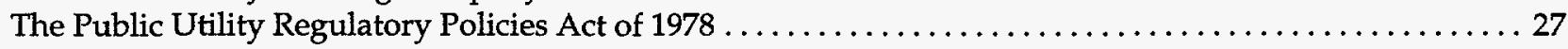

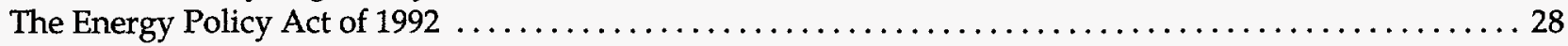

Part II: The U.S. Electric Power Industry in Transition to Competition $\ldots \ldots \ldots \ldots \ldots \ldots \ldots \ldots \ldots \ldots \ldots \ldots \ldots \ldots \ldots \ldots$

5. Factors Underlying the Restructuring of the Electric Power Industry $\ldots \ldots \ldots \ldots \ldots \ldots \ldots \ldots \ldots \ldots \ldots \ldots \ldots \ldots$

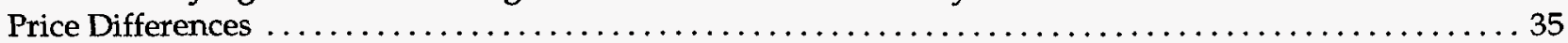

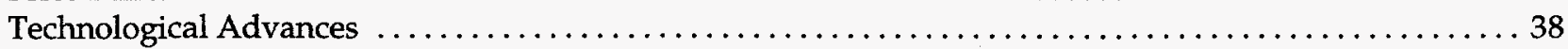

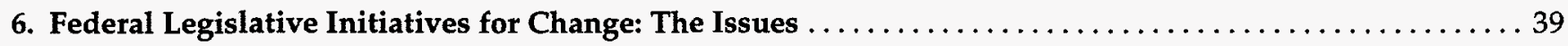

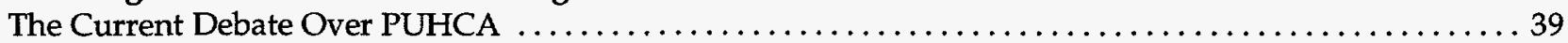

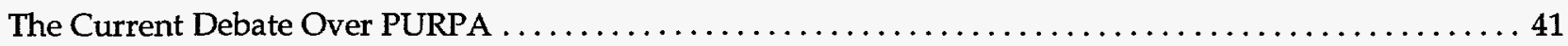

Proposed Comprehensive Energy Restructuring Bills $\ldots \ldots \ldots \ldots \ldots \ldots \ldots \ldots \ldots \ldots \ldots \ldots \ldots \ldots$

7. Evolving Regulatory Reform: The Federal and State Role in Promoting Competition ........... 51

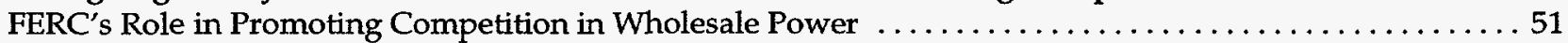

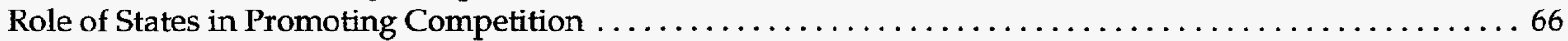

8. Stranded Costs in Electricity Deregulation: An Overview of Potential Mitigation Strategies ........ 77

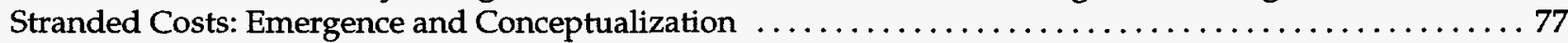

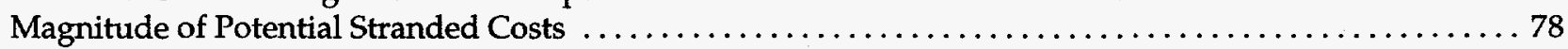

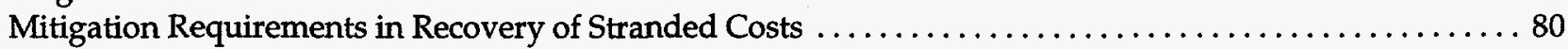

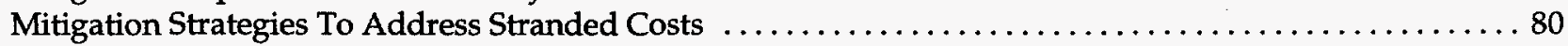

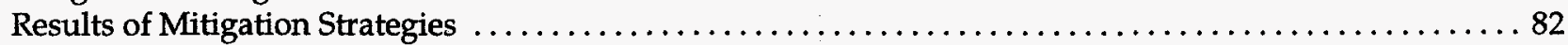

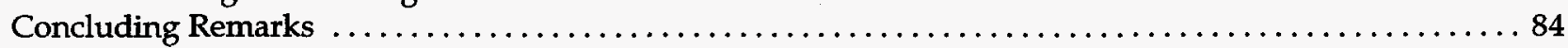

9. Transitional Developments and Strategies: The Industry Prepares for Competition $\ldots \ldots \ldots \ldots \ldots \ldots 85$

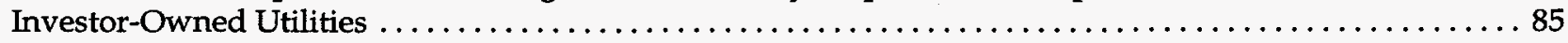

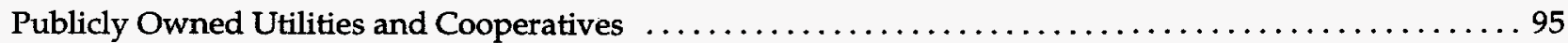




\section{Contents (Continued)}

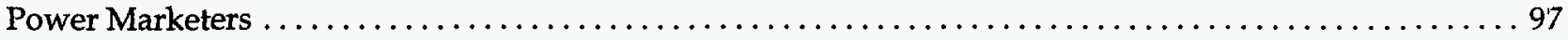

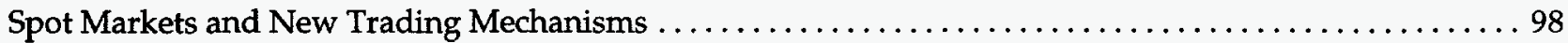

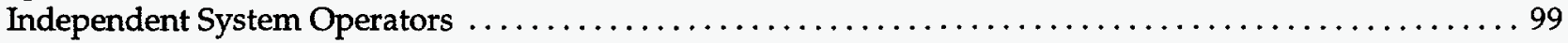

\section{Appendices}

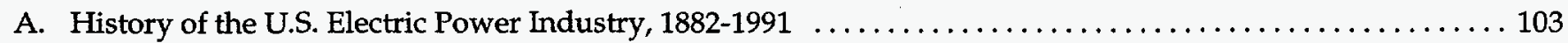

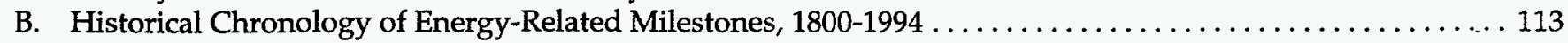

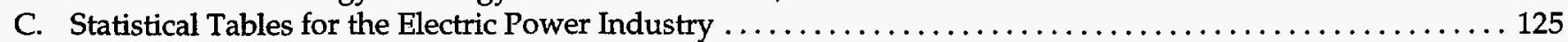

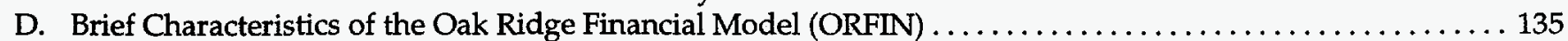

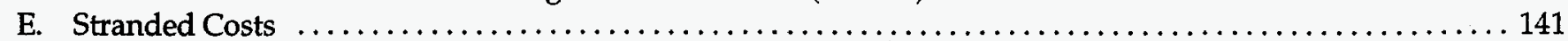

F. Selected Provisions of the Energy Policy Act of 1992 (Public Law 102-486), Title VII-Electricity . . ..... 159

G. Selected Provisions of the Federal Power Act Referenced in the FERC Mega-NOPR $\ldots \ldots \ldots \ldots \ldots \ldots$ 


\section{Tables}

1. Number of Electric Utilities by Class of Ownership and NERC Region, $1995 \ldots \ldots \ldots \ldots \ldots \ldots \ldots \ldots \ldots 11$

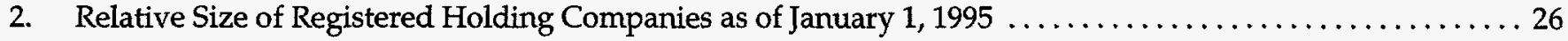

3. Total Projected Additions of Electricity Generating Capability for Electric Generators by Technology Type,

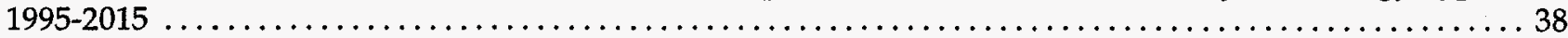

4. Proposed Legislation Influencing the Restructuring of the Electric Power Industry Introduced During the

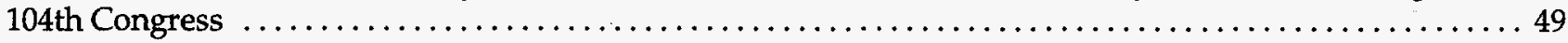

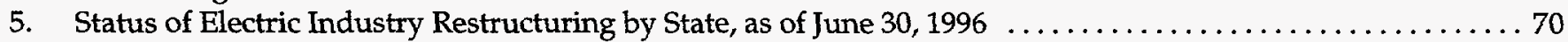

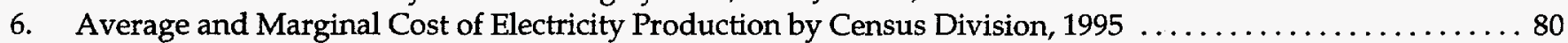

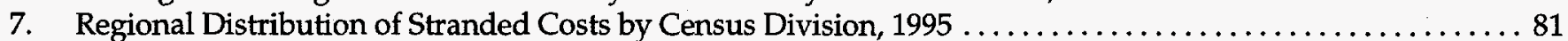

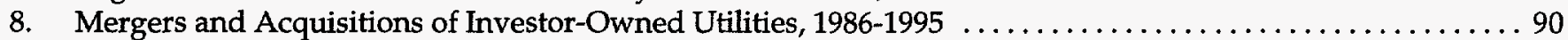

9. Number of Nonutility Subsidiary Companies Owned by Electric Utility Holding Companies, 1986-1994 . . 93

10. Investments in Exempt Wholesale Generators and Foreign Utilities in $1994 \ldots \ldots \ldots \ldots \ldots \ldots \ldots \ldots \ldots . \ldots \ldots$

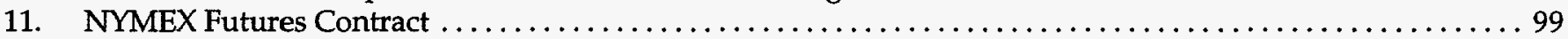

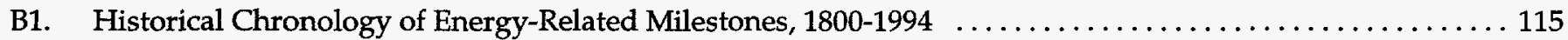

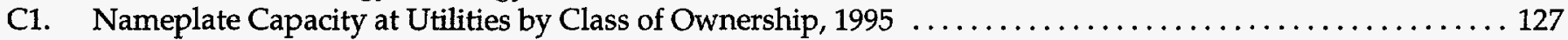

C2. Nameplate Capacity at Nonutilities by Type of Facility and Major Industry Group, $1995 \ldots \ldots \ldots \ldots \ldots .127$

C3. Planned Nameplate Capacity Additions in 1995 by Prime Mover and Type of Facility for the Electric

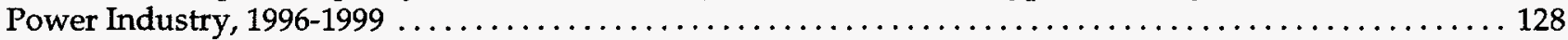

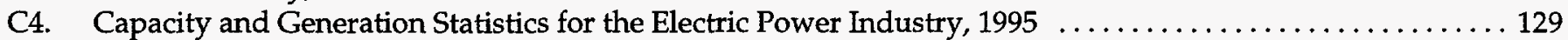

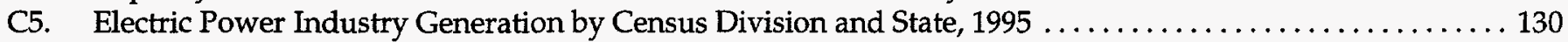

C6. Statistics of the Utility Sector of the Electric Power Industry, $1970-1995 \ldots \ldots \ldots \ldots \ldots \ldots \ldots \ldots \ldots \ldots \ldots \ldots . \ldots \ldots 131$

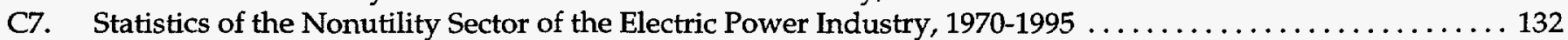

C8. Average Nameplate Capacity and Number of Utility-Operated Coal-Fired Steam Turbine Units by

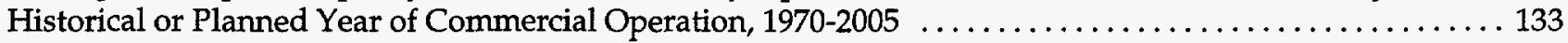

C9. Average Nameplate Capacity and Number of Nonutility-Owned Units by Selected Prime Mover and Historical or Planned Year that Electricity First Generated, $1970-1999 \ldots \ldots \ldots \ldots \ldots \ldots \ldots \ldots \ldots \ldots \ldots \ldots$

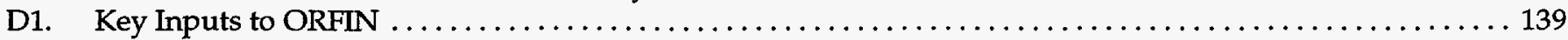

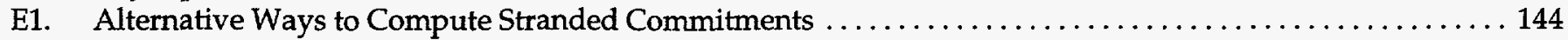

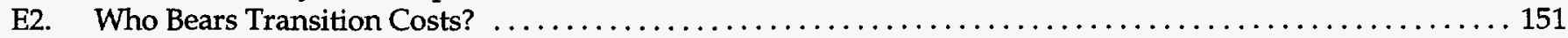

E3. Potential Effects of Different Strategies on Base-Case Utility Transition Costs $\ldots \ldots \ldots \ldots \ldots \ldots \ldots \ldots \ldots 2$

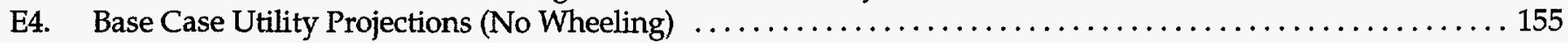

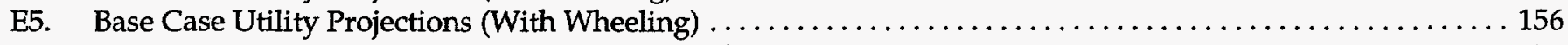

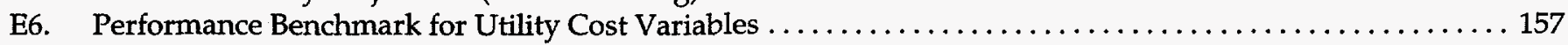

\section{Figures}

1. North American Electric Reliability Council Regions for the Contiguous United States and Alaska ....... 11

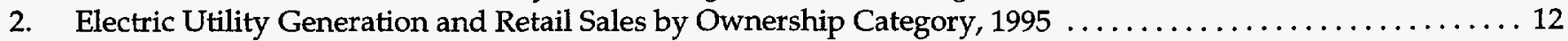

3. Shares of Nonutility Nameplate Capacity by Major Industry Group, $1995 \ldots \ldots \ldots \ldots \ldots \ldots \ldots \ldots \ldots \ldots \ldots$

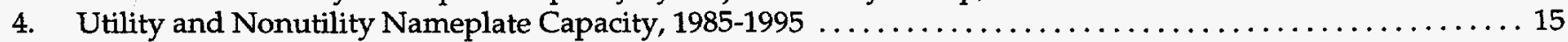

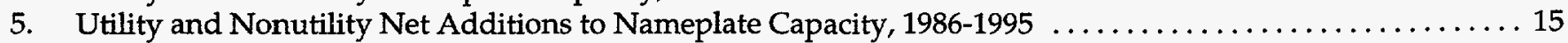

6. Utility and Nonutility Planned Additions to Nameplate Capacity, $1996-1998 \ldots \ldots \ldots \ldots \ldots \ldots \ldots \ldots$

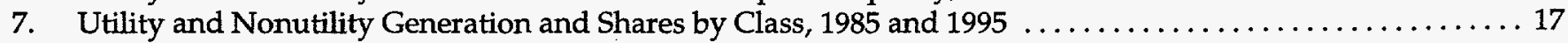

8. Regions and Interconnections of the North American Electric Reliability Council in the Contiguous

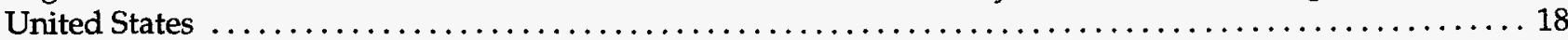

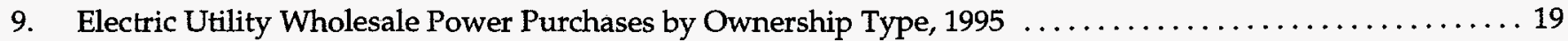

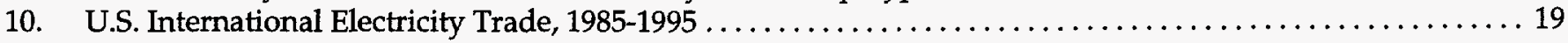

11. Average Revenue from Electricity Sales to All Retail Consumers by State, $1995 \ldots \ldots \ldots \ldots \ldots \ldots \ldots \ldots$

12. Average Revenue from Electricity Sales to Industrial Consumers by State, $1995 \ldots \ldots \ldots \ldots \ldots \ldots \ldots . \ldots 37$

13. Relative Average Revenue of Electricity Sales: Ratio of Industrial Consumers to All Consumers, 1960-1995 . 38

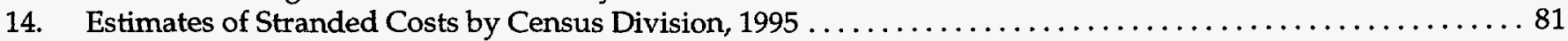

15. Allocation of Revenue Dollars from Electric Operations for Major U.S. Investor-Owned Utilities, 1995 . . . . 85 


\section{Figures (Continued)}

16. Allocation of Electric Operation and Maintenance Expenses of Major U.S. Investor-Owned Utilities, 1995 . . 86

17. Trends in Operation and Maintenance Expenses of Investor-Owned Utilities, 1986-1995 . . . . . . . . . . 87

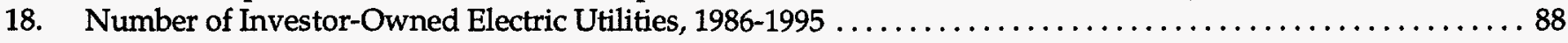

19. Comparison of Costs Before and After Merger of Iowa Power and Iowa Public Service ............ 92

20. Comparison of Costs Before and After Merger of Kansas P\&L and Kansas G\&E ................ 92

21. Allocation of Revenue Dollars from Electric Operations for Publicly Owned Generator Utilities, 1994 ..... 95

22. Allocation of Electric Operation and Maintenance Expenses for Publicly Owned Generator Utilities, 1994 .. 96

23. Operation and Maintenance Expenses for Publicly Owned Electric Utilities, 1989-1994 . . . . .......... 96

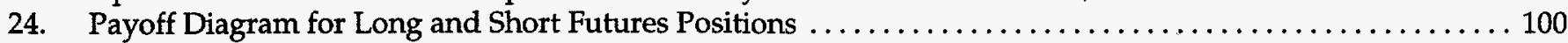

D1. Schematic Representation Defining ORFIN Assessment Framework $\ldots \ldots \ldots \ldots \ldots \ldots \ldots \ldots \ldots \ldots \ldots \ldots$ 


\section{Executive Summary}

Electric utilities 1 -one of the largest remaining regulated industries in the United States-are in the process of transition to a competitive market. Traditionally vertically integrated, ${ }^{2}$ the industry will in all probability be segmented at least functionally into its three component parts: generation, transmission, and distribution. The proposals and issues are being addressed in Federal and State legislation and are being debated in State regulatory hearings.

Change is occurring through the issuance by the Federal Energy Regulatory Commission (FERC) of Orders 888 and 889 (dated April 24, 1996) to encourage wholesale competition. Order 888 addresses the issues of open access to the transmission network and stranded costs. Order 889 requires utilities to establish electronic systems to share information about available transmission capacity. In addition, as of June 30,1996, 44 States and the District of Columbia (more than 88 percent of the Nation's regulatory commissions) have started activities related to retail competition in one form or another. ${ }^{3}$ Issues such as recovery of stranded costs, divestiture of transmission assets, increased mergers, renewable energy incentives, energy efficiency investments, reliability, and the timing of retail competition are critical due to the degree of importance electricity holds in this country's economic and social well-being. Legislative proposals on electric power restructuring have been introduced into the U.S. House of Representatives and the U.S. Senate.

The electric power industry has once before, during the late 1930s and early 1940s, undergone major realignment. However, the situation was very different then because it was forced by Federal law in order to bring an end to the financial exploitation of utilities and ratepayers by large holding companies. The current process for change is driven by extensive discussions and hearings at the Federal and State levels. For example, many consumers, primarily industrial, express the desire to choose the electricity supplier that meets their needs economically, reliably, and efficiently. Utility consumers have seen differences in prices in neighboring States (Figure ES1), and those States with higher electricity rates like California and those in the Northeast are promoting competition in the hope of making lower rates available. In fact, California, New York, and most of the New England States are opening their retail electric power markets to competition in 1998. Independent power producers look to an unconstrained market for expansion and increased profitability. Regulators are experimenting with alternative forms of regulation (e.g., performancebased rates) because some groups believe that the traditional practice of regulating a utility's rate of return ${ }^{4}$ does not contain sufficient incentives to encourage efficient utility operations. And utilities are dissatisfied with legislation that has given a competitive advantage to nonutility electricity producers and limits holding company activities.

With competition on the horizon, investor-owned utilities (IOUs) are reducing staff 'and reorganizing their companies to lower costs. IOUs have taken advantage of lower fuel prices by modifying their fuel acquisition procedures (such as buying out older, more expensive fuel contracts and purchasing less expensive coal in the spot market), which has helped decrease their real operation and maintenance costs (in 1995 dollars) from about 4.5 cents per kilowatthour in 1986 to 3.5 cents per kilowatthour in 1995 (Figure ES2). An increase in power purchases over the past decade has hindered efforts to lower costs for some utilities. On the other hand, nonfuel operation and maintenance costs have remained stable, indicating that some progress in cost reduction has been achieved, but also indicating that more may be needed.

Some of the largest IOUs companies are expanding their business investments in energy service companies; oil and gas exploration, development, and production; foreign ventures; and, more recently, telecommunications

\footnotetext{
${ }^{1}$ An electric utility is a corporation, person, agency, authority, or other legal entity or instrumentality that owns and/or operates facilities in the United States, its territories, or Puerto Rico, for the generation, transmission, distribution, or sale of electric energy primarily for use by the public.

${ }^{2}$ A vertically integrated utility is one which engages in generation, transmission, and distribution operations.

${ }^{3}$ These numbers are drawn from the research undertaken by Dr. Jeff Fang of the National Renewable Energy Laboratory with funding provided by the Energy Information Administration.

${ }^{4}$ Rate of return is the ratio of net operating income earned by a utility, calculated as a percentage of its rate base.
} 
Figure ES1. Average Revenue from Electricity Sales to All Retail Consumers by State, 1995 (Cents per Kilowatthour)

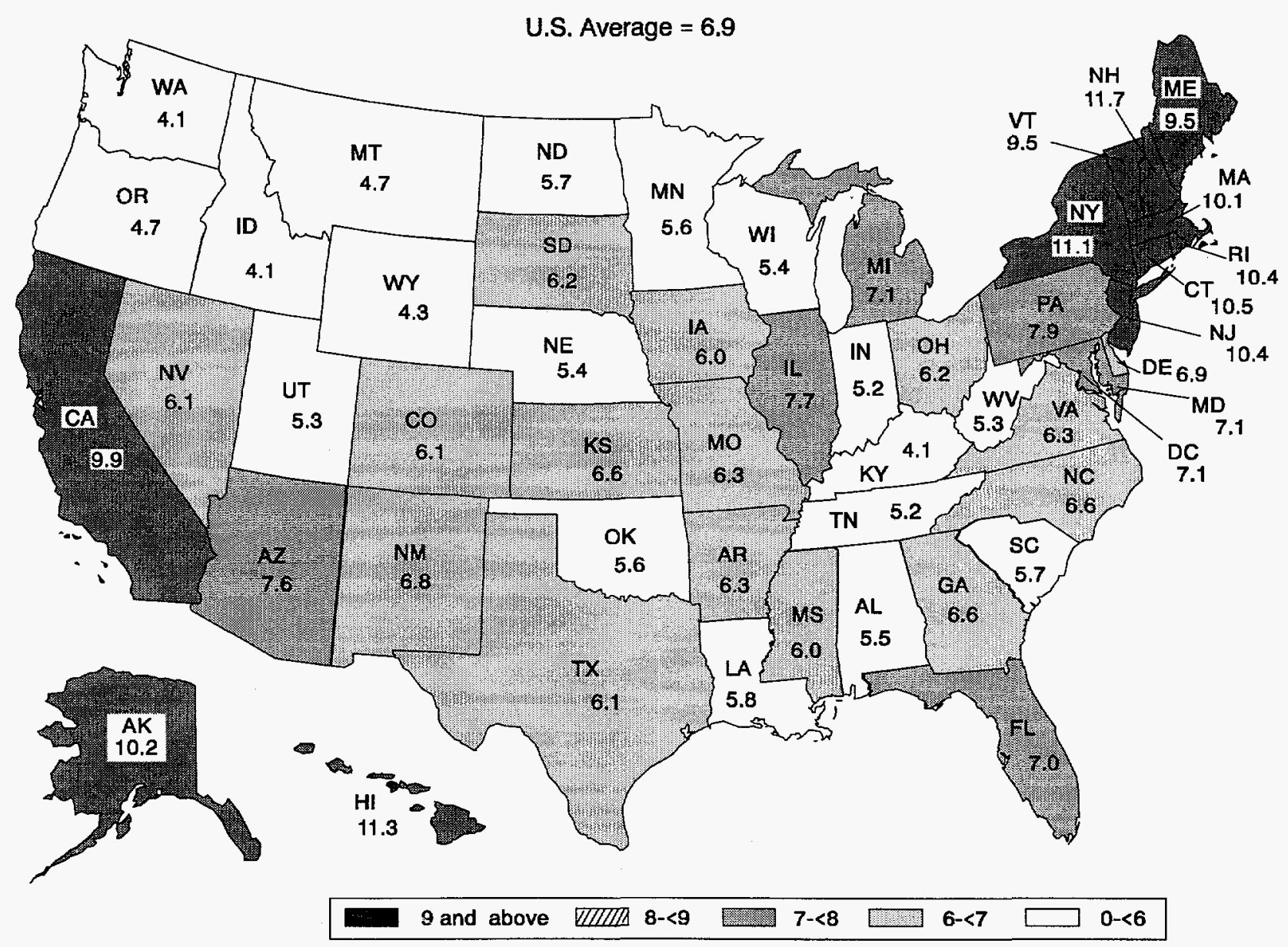

Source: Energy Information Administration, Electric Power Annual 1995, Volume II, DOE/E|A-0348(95)/2 (Washington, DC, December 1996), Table 7.

ventures. Electric utilities are also planning to improve their competitive positions through mergers and acquisitions. In 1995, 13 investor-owned electric utilities merged or had mergers pending with other utilities in the industry, as compared with 1 in 1994 and 4 in 1993. Company executives claim that such mergers result in cost savings. However, comparing costs before and after two of the mergers in 1992 indicates that savings do not always occur.

Publicly owned utilities and rural electric cooperatives will also be affected by industry restructuring. In general, they have lower operating costs than IOUs, and most of them can sell electricity at a competitive price. However, with increased competition from IOUs and electricity marketing companies, publicly owned utilities and cooperatives may find that they need to lower costs. Many of them are now reacting to competitive pressures by reducing staff and engaging in other cost-cutting activities. Although a few publicly owned utilities have recently announced merger plans, there is not a significant merger trend when compared to IOUs. Publicly owned utilities can capture some of the same efficiencies of a merger by sharing resources and forming mutual aid programs. Objections to merger plans of IOUs have been raised by some publicly owned utilities who contend that mergers result in unnecessary consolidation of generation capacity and create excess market power.

In addition to the activities of electric utilities, other important events are taking place in the industry. Power marketers-companies that buy and then resell electric 
Figure ES2. Operation and Maintenance (O\&M) Costs of Major Investor-Owned Utilities, 1986-1995

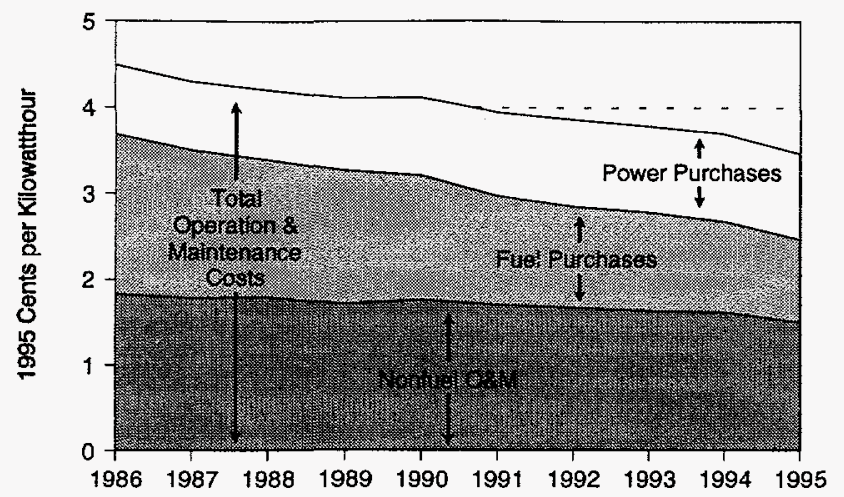

Source: Energy Information Administration, Financial Statistics of Major U.S. Investor-Owned Electric Utilities 1995, DOE/EIA-0437(95)/1 (Washington, DC, December 1996), and previous issues.

energy and transmission and other services from traditional utilities-are emerging as new players in the industry. Although relatively small in terms of volume of sales (i.e., less than 5 percent of wholesale electricity sales in 1995), power marketers are a growing segment of the industry. Stimulating this growth, electricity spot markets are operating at several sites across the country. Power marketers and some electric utilities are using spot markets as an alternative source of wholesale power. The California-Oregon Border (COB) and the Palo Verde switchyard are two of the largest electricity trading centers at this time. Electricity futures contracts, new financial instruments that help traders manage the risks in electricity trading, were started at $\mathrm{COB}$ and Palo Verde in March 1996. Finally, the concept of an independent system operator (ISO), an entity that will independently manage a transmission grid owned by one or more electric generation companies, is growing in importance. ISOs are considered by most to be a key component for achieving effective wholesale competition. The California Public Utility Commission's proposal to transfer operational control (but not ownership) of certain transmission facilities to an ISO is perhaps the most publicized plan. Proposals to start ISOs are also being discussed in New York, Wisconsin, Massachusetts, Texas, and other States.

Stranded costs are a major concern to many industry groups, especially to the electric utilities. These are costs that have been prudently incurred by utilities to serve their consumers but cannot be recovered if the consumers choose other electricity suppliers. One study has estimated current stranded assets at $\$ 88$ billion, and estimates of projected stranded costs range from a low of $\$ 10$ to $\$ 20$ billion to a high of $\$ 500$ billion. ${ }^{5}$ Utilities are looking for ways to mitigate stranded costs, and regulators are evaluating who should pay them. The strategies being considered would allocate the costs to ratepayers, shareholders, wheeling customers, taxpayers, and/or nonutility suppliers. Ideas such as delaying the start of retail competition, charging exit fees to departing customers, reducing administrative and general costs, and discounting qualifying facility energy payments are being considered and are likely to result in reductions of 25 percent or more in an at-risk utility's stranded costs. ${ }^{6}$ In Order 888, FERC stated that recovery of stranded costs should be allowed because it is critical to the successful transition to a competitive wholesale environment with open access to transmission capacity. The stranded costs will be recovered from departing wholesale customers.

At this time, the outcome of the reforms being considered cannot be definitively predicted, nor can all of the impacts be foreseen. It is the intention of this report to describe the forces motivating the move to competition, the relevant laws and regulations, the trends and current developments, the roles of industry players and regulators, and the concerns of consumers. Subsequent reports by the Energy Information Administration will give updates on the status of proposed reforms and, where possible, will analyze the effects of the transition on such matters as electricity demand, pricing, reliability, social and environmental programs, bulk power markets, technological advances, issues and trends in fuel use, and stranded cost recovery methods in the States.

\footnotetext{
${ }^{5}$ The low estimates of stranded costs are attributable to the American Public Power Association. The high estimates come from many sources. See Chapter 8 for further information.

${ }^{6}$ Oak Ridge National Laboratory, ORFIN: An Electric Utility Financial and Production Simulator, ORNL/CON-431 (Oak Ridge, TN, March 1996).
} 


\section{Introduction}

The U. S. electric power industry today is on the road to restructuring - a road heretofore uncharted. While parallels can be drawn from similar journeys taken by the airline industry, the telecommunications industry, and, most recently, the natural gas industry, the electric power industry has its own unique set of critical issues that must be resolved along the way. The transition will be from a structure based on a vertically integrated and regulated monopoly to one equipped to function successfully in a competitive market.

The long-standing traditional structure of the electric power industry is the result of a complex web of events that have been unfolding for over 100 years. Some of these events had far-reaching and widely publicized effects (e.g., Franklin D. Roosevelt's New Deal in the 1930s, the Northeast Blackout of 1965, the Arab Oil Embargo of 1973, and the Three Mile Island incident in 1979). Other major events took the form of legislation (e.g. the Public Utility Holding Company Act of 1935 [PUHCA], the Public Utility Regulatory Policies Act of 1978 [PURPA], and the Energy Policy Act of 1992 [EPACT]). Still other events had effects that are less obvious in comparison (e.g., the appearance of technologies such as transformers and steam and gas turbines, the invention of home appliances, the man-made fission of uranium), and it is likely that their significance in the history of the industry has been obscured by the passage of time. Nevertheless, they, too, hold a place in the underpinnings of today's electric industry structure.

The old school of thought that considered utility power generation, transmission, and distribution a "natural monopoly" ${ }^{\prime 1}$ has given way to a general consensus that the generation segment of power supply in today's environment would be more efficient and economical if left to the forces of an open market. The era of competition in the electric industry is upon us. The groundwork was laid, albeit unintentionally, by the passage of PURPA, which opened wholesale markets to nonutility producers of electricity in 1978, and EPACT, which expanded those markets in 1992. In 1996, the Federal Energy Regulatory
Commission (FERC) issued rules for implementing open access to the transmission network and recovering stranded costs. The State public utility commissions are actively studying retail competition, and some have already introduced pilot programs or have drawn up plans for restructuring. An electricity futures market and newly formed entities, such as power marketers and brokers and independent system operators, are emerging and are taking their respective places in the dynamic composition of the industry. In relation to the length of time that the industry has existed and that utilities have been vertically integrated, changes are happening almost overnight.

The purpose of this report, which is intended for both lay and technical readers, is twofold. First, it is a basic reference document that provides a comprehensive delineation of the electric power industry and its traditional structure, which has been based upon its monopoly status. Second, it describes the industry's transition to a competitive environment by providing a descriptive analysis of the factors that have contributed to the interest in a competitive market, proposed legislative and regulatory actions, and the steps being taken by the various components of the industry to meet the challenges of adapting to and prevailing in a competitive environment. In order to facilitate the presentation, the report is divided into two parts.

Part I provides a historical overview of the electric power industry-a requisite piece to the changing structure puzzle. Before the transitional state of the current industry can be fully comprehended, it is necessary to understand the conventional roles of the components of electricity supply and factors that have affected them from the beginning, including legislative and regulatory mandates, advancing technologies, and fluctuating economic conditions. To that end, the overview section presents an abridged version of the industry's history, touching on the events that have had the most profound effect on its structure. Also included is an in-depth look at the industry's current structure and its generating, transmitting, and distributing components. The substantially involved

\footnotetext{
1 "The critical and-if properly defined-all-embracing characteristic of natural monopoly is an inherent tendency to decreasing costs over the entire extent of the market. This is so only when the economies achievable by a larger output are internal to the individual firm-if, that is to say, it is only as more output is concentrated in a single supplier that unit costs will decline." Alfred E. Kahn, The Economics of Regulation, Principles and Institutions, Vol. 2 (Cambridge, MA: The MIT Press, 1988), p. 119.
} 
subject of utility and nonutility organizational entities and their roles and relationships is examined in detail to provide an essential basic understanding of the supply component terms used throughout this report. Major legislation that has had the most profound impact on the structure of the industry over the years is discussed, and the discussion is accompanied by a table summarizing each law's requirements along with additional laws that have had significant effects on power suppliers. The entirety of Part I was designed to be a convenient handbook that can be continually referenced to answer questions concerning the fundamentals of the electric power industry.

Part II addresses the current restructuring issues and events. It outlines the forces behind the drive to restructure. The legislative proposals for reform and restructuring that have been introduced into the U.S. Congress are cited and summarized, and the Federal and State roles in promoting competition through regulatory reform are described. The issue of stranded costs-that is, the costs utilities have prudently incurred to serve their customers but which cannot be recovered if the customers choose other electricity suppliers-are examined. Strategies to recover such costs are discussed, along with the question of who will bear the costs. In addition, Part II presents a detailed discussion of industry plans and developments that are emerging as a direct result of the move toward competition, including strategies to lower costs and other actions planned or already taken by major investor-owned utilities to prepare for competition. Likewise, the tactics of public utilities and cooperative utilities are examined.

This report also updates the statistics given in its predecessor, The Changing Structure of the Electric Power Industry 1970-1991. That report, published in March 1993, portrayed the evolving roles of electric utilities and nonutilities and the corresponding data regarding the changing patterns of electricity generation and capacity for both. Other trends were graphically illustrated and accompanied by an interpretive analysis. Many of those statistics are updated in Chapter 3, and additional data updates are presented in Appendix $C$. 


\section{Part I:}

\section{The U.S. Electric Power Industry as a Monopoly}





\section{A Brief Historical Overview of the Electric Power Industry}

At the turn of the century, vertically integrated ${ }^{2}$ electric utilities produced approximately two-fifths of the Nation's electricity. At the time, many businesses (nonutilities) generated their own electricity. When utilities began to install larger and more efficient generators and more transmission lines, the associated increase in convenience and economical service prompted many industrial consumers to shift to the utilities for their electricity needs. With the invention of the electric motor came the inevitable use of more and more home appliances. Consumption of electricity skyrocketed along with the utility share of the Nation's generation.

Utilities operated in designated exclusive franchise areas which, in the early years, were usually municipalities. Along with the service area designation came the obligation to serve all consumers within that territory. "The growth of utility service territories ... brought State regulation of privately owned electric utilities in the early 1900s. Georgia, New York, and Wisconsin established State public service commissions in 1907, followed shortly by more than 20 other States. Basic State powers included the authority to franchise the utilities, to regulate their rates, financing, and service, and to establish utility accounting systems."

The early structure of the electric utility industry was predicated on the concept that a central source of power supplied by efficient, low-cost utility generation, transmission, and distribution was a natural monopoly. Because monopolies in the United States were outlawed by the Sherman Antitrust Act, ${ }^{4}$ regulation of the utilities was a necessity. In addition to its intrinsic design to protect consumers, regulation generally provided reliability and a fair rate of return to the utility. The result was traditional rate base regulation. (This form of rate setting has been blamed by some groups for removing the incentive for utilities to achieve maximum efficiency in operations and planning, thereby exhibiting the major

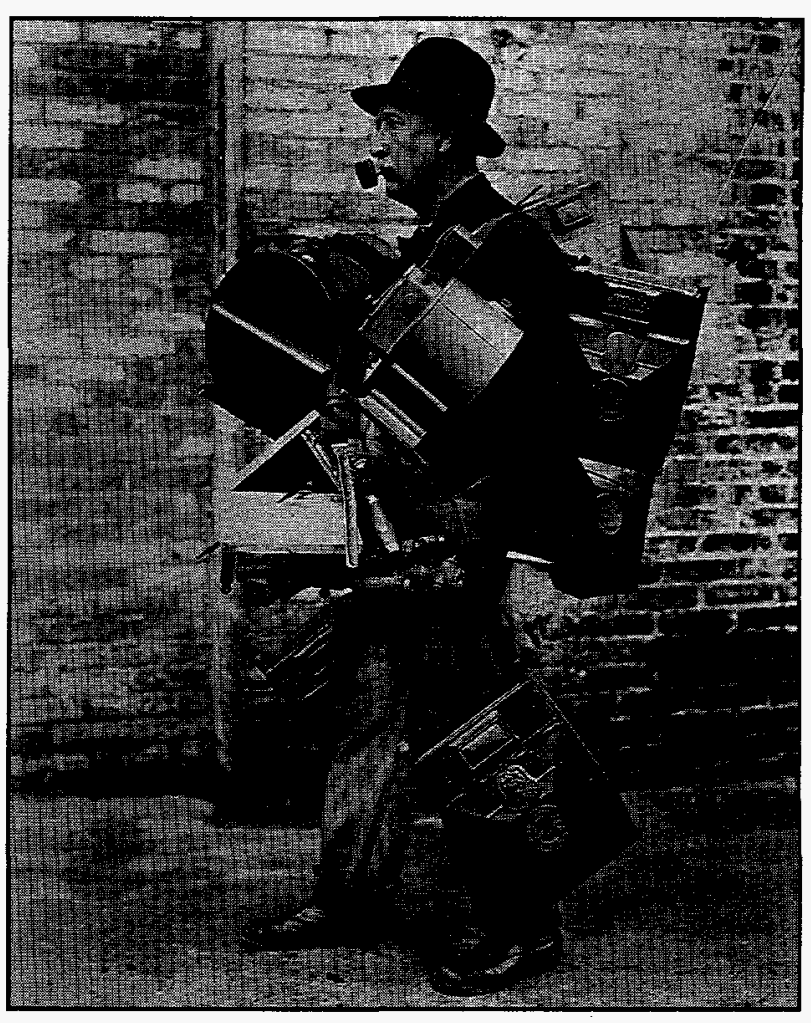

Meter setter of the late 1800 s makes his rounds. Photograph courtesy of the Baltimore Gas and Electric Company.

flaw in this type of regulation and promoting the push for its demise.)

Electric utility holding companies were forming and expanding during this period, and by the 1920 s they controlled much of the industry. At their peak in the late 1920s, the 16 largest electric power holding companies controlled more than 75 percent of all U.S. generation. ${ }^{5}$ Originally formed to reap the benefits (mostly of a financial nature) of centralized ownership of a multitude of subsidiaries, these unregulated holding companies

\footnotetext{
${ }^{2}$ A vertically integrated utility is one which engages in generation, transmission, and distribution operations.

${ }^{3}$ Energy Information Administration, Annual Outlook for U.S. Electric Power 1985, DOE/EIA-0474(85) (Washington, DC, August 1985 ), p. 3.

${ }^{4}$ The Clayton Antitrust Act of 1914 strengthened the Sherman Antitrust Act of 1890.

${ }^{5}$ Encyclopedia Americana, International Edition, Vol. 22 (New York, NY: Americana Corporation, 1977), p. 769.
} 


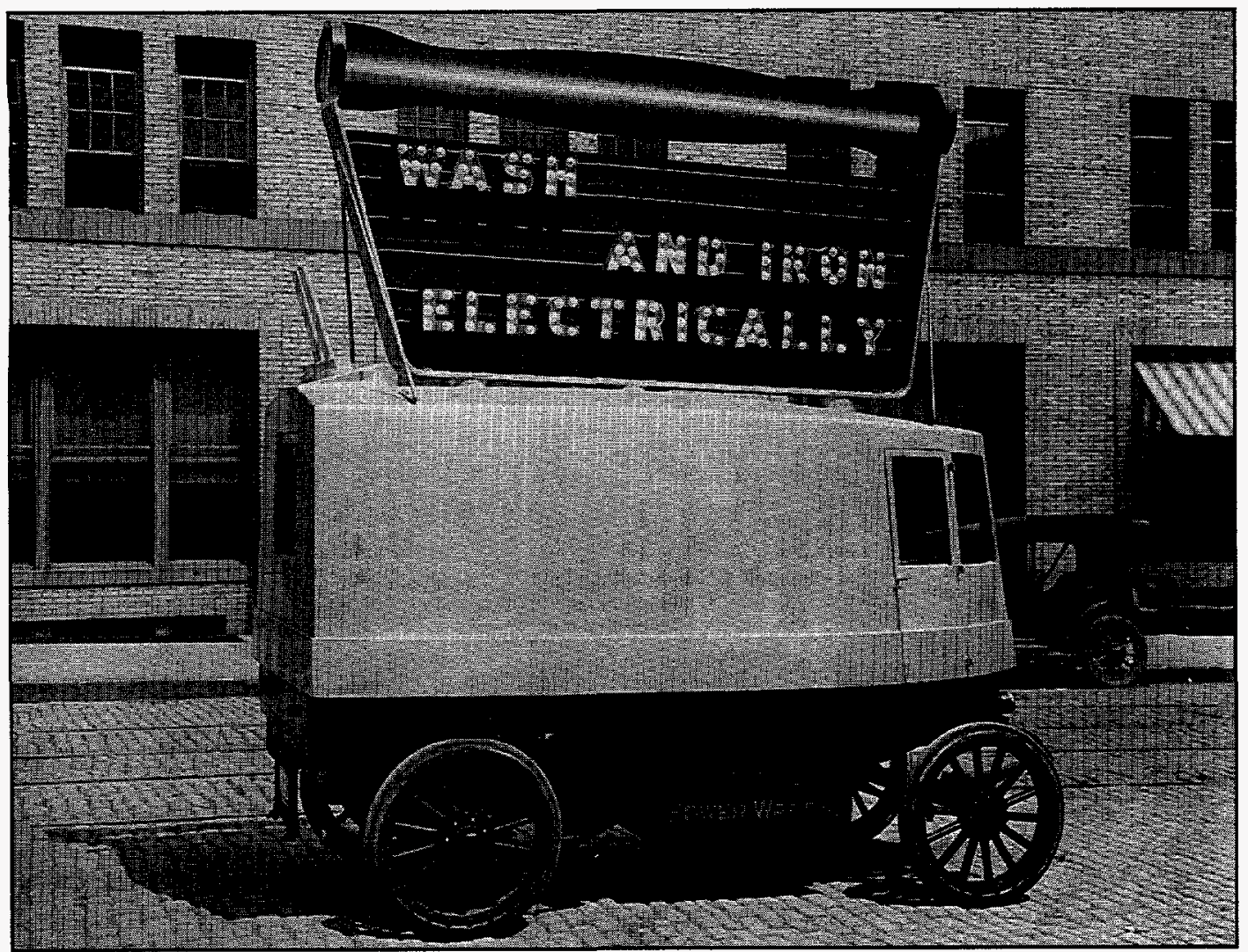

Electrically powered wagon used to promote the use of electric appliances, 1917. Photograph courtesy of the Baltimore Gas and Electric Company.

were in a position to abuse their power over their subsidiaries. Sometimes, the result was increased costs paid by consumers of electricity. Because the States could not regulate an interstate holding company, it became apparent that the Federal Government would have to step in. After several large holding company systems collapsed, an investigation by the Federal Trade Commission was ordered, leading eventually to the passage of the Public Utility Holding Company Act of 1935 (PUHCA). Under the provisions of the Act, holding companies became regulated by the Securities and Exchange Commission. Utilities, which were involved in interstate wholesale marketing or transmission of electric power, became regulated by the Federal Power Commission (FPC). In October 1977, the FPC became the Federal Energy Regulatory Commission (FERC).

By 1921, privately owned utilities were providing 94 percent of total generation, and publicly owned utilities contributed only 6 percent. ${ }^{6}$ In the following decade, President Franklin D. Roosevelt implemented a New Deal plan to build four hydroelectric power projects to be owned and operated by the Federal Government. Roosevelt was able to get public power "on its feet." In 1937, the development of Federal power marketing administrations began. Federal electricity generation steadily expanded, providing less expensive electricity to municipal and cooperative utilities. By 1940, Federal power pricing policy was set; all Federal power was marketed at the lowest possible price while still covering costs. $^{7}$ From 1933 to 1941, half of all new capacity was provided by Federal and other public power installations. By the end of 1941, public power contributed 12 percent of total utility generation, and Federal power alone contributed almost 7 percent. $^{8}$ Even during the Eisenhower Administration's policy of "no new starts," Federal power continued to grow as earlier projects came on line.

\footnotetext{
${ }^{6}$ Energy Information Administration, Annual Outlook for U.S. Electric Power 1985, DOE/EIA-0474(85) (Washington, DC, August 1985 ), p. 3.

${ }^{7}$ Ibid., p. 4.

${ }^{8}$ Edison Electric Institute, Historical Statistics of the Electric Utility Industry Through 1970 (Washington, DC, September 1973 ), pp. 2, 24.
} 


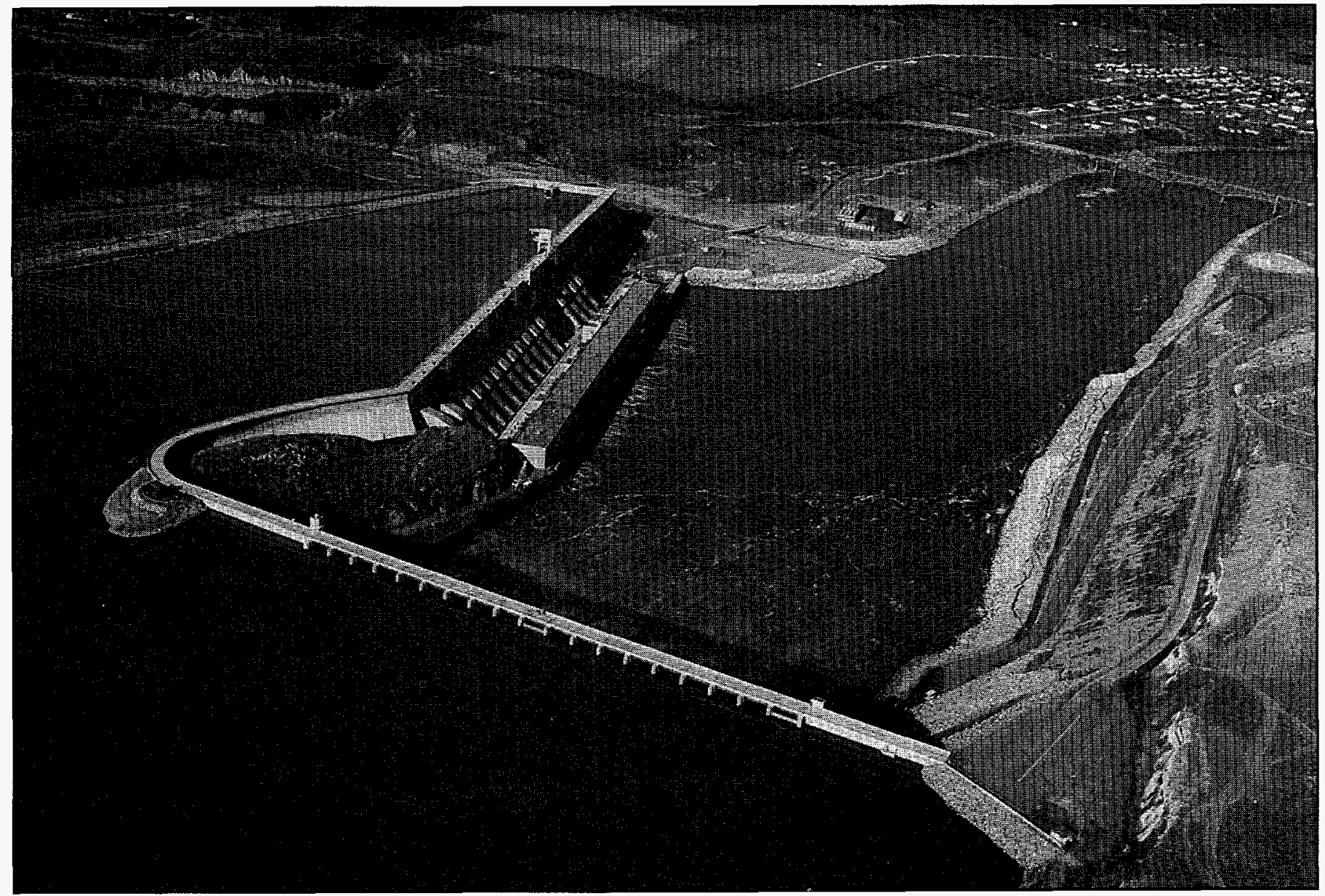

Chief Joseph Dam on the Columbia River, Washington, is a Bonneville Power Administration hydroelectric dam. U.S. Department of Energy photograph.

In the mid-1930s, many homes, farms, and ranches in rural areas were still without lights, indoor bathrooms, refrigerators, or running water. It was too expensive for the investor-owned utilities that served the cities to stretch their lines into the countryside, so many areas remained without access to electric power. The Federal Government encouraged the growth of rural electricity service by subsidizing the formation of rural electric cooperatives. The Rural Electrification Act of 1936 established the Rural Electrification Administration (REA) ${ }^{9}$ to provide loans and assistance to organizations providing electricity to rural areas and towns with populations under 2,500. REAbacked cooperatives enjoyed Federal power preferences ${ }^{10}$ plus lower property assessments, exemptions from Federal and State income taxes, and exemption from
State and Federal Power Commission regulation. ${ }^{11}$ As a result, by 1941 the proportion of farm homes electrified rose to 35 percent, more than three times that of $1932 .{ }^{12}$

For decades, utilities were able to meet increasing demand at decreasing prices. Economies of scale were achieved through capacity additions, technological advances, and declining costs, even during periods when the economy was suffering. Of course, the monopolistic environment in which they operated left them virtually unhindered by the worries that would have been created by competitors.

This overall trend continued until the late 1960s, when the electric utility industry saw decreasing unit costs and rapid growth give way to increasing unit costs and slower

\footnotetext{
${ }^{9}$ The Rural Electrification Administration has been replaced by the Rural Utilities Service, whose mission is to improve the quality of life in rural America by administering its Electrification, Telecommunications, and Water and Waste Disposal Programs.

${ }^{10}$ The Federal Government moved quickly in the mid-1930s to, where opportunities appeared, produce and distribute less expensive federally produced electricity to preference customers.

${ }^{11}$ Energy Information Administration, Annual Outlook for U.S. Electric Power 1985, DOE/EIA-0474(85) (Washington, DC, August 1985), p. 4.

${ }^{12}$ Energy Information Administration, Annual Outlook for U.S. Electric Power 1985, DOE/EIA-0474(85) (Washington, DC, August 1985 ), p. 6.
} 
growth. ${ }^{13}$ Over a relatively short time, a number of events took place which contributed to the unprecedented reversal in the growth and well-being of the industry: the Northeast Blackout of 1965 raised pressing concerns about reliability; the passage of the Clean Air Act of 1970 and its amendments in 1977 required utilities to reduce pollutant emissions; the Arab Oil Embargo of 1973-74 resulted in burdensome increases in fossil-fuel prices; the accident at Three Mile Island in 1979 led to higher costs, regulatory delays, and greater uncertainty in the nuclear industry; and inflation in general caused, among other problems, interest rates to more than triple.

While the industry was attempting to recover from this onslaught of damaging events, Congress designed legislation that would reduce U.S. dependence on foreign oil, develop renewable and alternative energy sources, sustain economic growth, and encourage the efficient use of fossil fuels. One result was the passage of the Public Utility Regulatory Policies Act of 1978 (PURPA). PURPA became a catalyst for competition in the electricity supply industry, because it allowed nonutility facilities ${ }^{14}$ that met certain ownership, operating, and efficiency criteria established by FERC to enter the wholesale market. Utilities initially did not welcome this forced competition, but some soon found that buying generation from a qualifying facility $(Q F)$ had certain advantages over adding to their own capacity, especially because of the increasing uncertainty of recovering capital costs. The growth of nonutilities was further advanced by the Energy Policy Act of 1992 (EPACT). EPACT expanded nonutility markets by creating a new category of power producers, exempt wholesale generators (EWGs), which are exempt from PUHCA's corporate and geographic restrictions. Like QFs, EWGs are wholesale producers that do not sell retail and do not own transmission facilities. Moreover, unlike the nonutilities qualified under PURPA, EWGs are not regulated and may charge market-based rates, and utilities are not required to buy their power. (For a more detailed description of the purpose and effects of PUHCA, PURPA, and EPACT, see Chapter 4 of this report.)

A more detailed account of the industry's history is provided in Appendix A, "History of the U.S. Electric Power Industry, 1882-1991." Appendix B, "Historical Chronology of Energy-Related Milestones, 1800-1994," lists the major technological and institutional events in the development of the U.S. electric power industry. The following chapter describes the organizational components of today's electric power industry.

${ }^{13}$ Energy Information Administration, Annual Outlook for U.S. Electric Power 1985, DOE/EIA-0474(85) (Washington, DC, August 1985), p. 7

${ }^{14}$ A nonutility is a corporation, person, agency, authority, or other legal entity or instrumentality that owns electric generating capacity and is not an electric utility. Nonutility power producers include qualifying cogenerators, qualifying small power producers, and other nonutility generators (including independent power producers) without a designated franchise service area, and which do not file forms listed in the Code of Federal Regulations, Title 18, Part 141. 


\section{Electric Power Generation Components}

U.S. electric power generators consist of two broad categories of energy producers-utilities and nonutilities. This chapter provides a brief look at the subject of utility and nonutility organizational entities and their roles and relationships. It is intended to provide an essential basic understanding of the generation component terms used throughout this report.

\section{Utilities}

Electric utilities in general are defined as privately owned companies and public agencies engaged in the generation, transmission, and/or distribution of electric power for public use ${ }^{15}$ Electric utilities can be divided into the following four ownership categories, each with its own set of distinct characteristics: investor-owned, Federally owned, other publicly owned (i.e., owned by State, municipal, or other governmental entities), and cooperatively owned (see inset on page 10).

There are currently 3,199 utilities throughout the United States (Table 1 and Figure 1), but only approximately 700 of them operate facilities that generate electric power. Many electric utilities are exclusively distribution utilities-that is, they purchase wholesale power from others to distribute it, over their own distribution lines, to the ultimate consumer. Three of the four types of utilities actually sell more power at retail than they generate (Figure 2).

Some electric utilities have service territories extending beyond a single county or parish. Others just serve a municipality or part of a county. Many counties in the United States are served by more than a single utility, and some parts of the country have more than 10 electric utilities operating in a county. In order to move electricity among utilities, an extensive system of high-voltage transmission lines is owned and operated by the Nation's larger utilities. This transmission network permits electricity trading between utilities; without transmission facilities, electricity could not be moved from power plants to the thousands of distribution systems serving millions of consumers of electric power.

\section{Investor-Owned Utilities}

There are two basic organizational forms among investorowned companies. The most prevalent is the individual corporation. Another common form is the holding company, in which a parent company is established to own one or more operating utility companies that are integrated with one another. Most of the investor-owned utilities sell power at retail rates to several different classes of consumers and at wholesale rates to other utilities, including investor-owned, Federal, State, and local government utilities, public utility districts, and rural electric cooperatives. In 1995, only 244 of the 3,199 U.S. utilities were investor owned, but they accounted for more than 75 percent of both utility sales to ultimate consumers and total utility generation.

\section{Federal Utilities}

According to Energy Information Administration (EIA) classification, there are 10 Federal electric utilities in the United States. They are:

- The Department of Energy's five power marketing administrations (Alaska, ${ }^{16}$ Bonneville, Southeastern, Southwestern, and Western Area Power Administrations)

- The Department of Defense's U.S. Army Corps of Engineers

- The Department of the Interior's U.S. Bureau of Indian Affairs

\footnotetext{
${ }^{15}$ More specifically, public utilities are defined as enterprises that provide essential public services, such as electric, gas, telephone, water, and sewer, under legally established monopoly conditions, whereas publicly owned electric utilities include only those utilities operated by municipalities and State and Federal power agencies. Privately owned (or investor-owned) electric utilities are regulated and produce a return for investors (see inset).

${ }^{16}$ Public Law 104-58, The Alaska Power Administration Asset Sale and Termination Act, passed on November 28, 1995, authorizes and directs the Secretary of Energy to sell the Alaska Power Administration. The Alaska PMA comprises the Eklutna Hydroelectric Project and the Snettisham Hydroelectric Project. The former is to be sold before December 31, 1997, and the latter by August 1998.
} 


\begin{tabular}{|c|c|}
\hline \multicolumn{2}{|c|}{ Major Characteristics of U.S. Electric Utilities by Type of Ownership } \\
\hline Ownership & Major Characteristics \\
\hline $\begin{array}{l}\text { Investor-Owned Utilities (IOUs) } \\
\text { IOUs account for about three-quarters of } \\
\text { all utility generation and capacity. There } \\
\text { are } 244 \text { in the United States, and they } \\
\text { operate in all States except Nebraska. } \\
\text { They are also referred to as privately } \\
\text { owned utilities. }\end{array}$ & $\begin{array}{l}\text { - Earn a return for investors; either distribute their profits to stockholders as } \\
\text { dividends or reinvest the profits } \\
\text { - Are granted service monopolies in certain geographic areas } \\
\text { - Have obligation to serve and to provide reliable electric power } \\
\text { - Are regulated by State and sometimes Federal governments, which in turn } \\
\text { approve rates that allow a fair rate of return on investment } \\
\text { - Most are operating companies that provide basic services for generation, } \\
\text { transmission, and distribution }\end{array}$ \\
\hline $\begin{array}{l}\text { Federally Owned Utilities } \\
\text { There are } 10 \text { Federally owned utilities in } \\
\text { the United States, and they operate in } \\
\text { all areas except the Northeast, the } \\
\text { upper Midwest, and Hawaii. }\end{array}$ & $\begin{array}{l}\text { - Power not generated for profit } \\
\text { Publicly owned utilities, cooperatives, and other nonprofit entities are given } \\
\text { preference in purchasing from them } \\
\text { - Primarily producers and wholesalers } \\
\text { - Producing agencies for some are the U.S. Army Corps of Engineers, the U.S. } \\
\text { - Bureau of Reclamation, and the International Water and Boundary Commission } \\
\text { The electricity generated by these agencies is marketed by Federal power } \\
\text { marketing administrations in DOE (Bonneville Power Administration, } \\
\text { Southeastern Power Administration, Southwestern Power Administration, and } \\
\text { Western Area Power Administration) } \\
\text { - The Alaska Power Administration is in the process of being privatized per } \\
\text { Public Law } 104-58 \text { enacted on November } 28,1995 \\
\text { - The Tennessee Valley Authority is the largest producer of electricity in this } \\
\text { category and markets at both wholesale and retail levels }\end{array}$ \\
\hline $\begin{array}{l}\text { Other Publicly Owned Utilities } \\
\text { Other publicly owned utilities include: } \\
\text { Municipals } \\
\text { Public Power Districts } \\
\text { State Authorities } \\
\text { Irrigation Districts } \\
\text { Other State Organizations } \\
\text { There are 2,014 in the United States. }\end{array}$ & $\begin{array}{l}\text { - Are non-profit State and local government agencies } \\
\text { - Serve at cost; return excess funds to the consumers in the form of community } \\
\text { contributions, economic and efficient facilities, and reduced rates } \\
\text { - Most municipals just distribute power, although some large ones produce and } \\
\text { transmit; they are financed from municipal treasuries and revenue bonds } \\
\text { - Public power districts and projects are concentrated in Nebraska, Washington, } \\
\text { Oregon, Arizona, and California; voters in a public power district elect } \\
\text { commissioners or directors to govern the district independent of any municipal } \\
\text { government } \\
\text { - Irrigation districts may have still other forms of organization (e.g., in the Salt } \\
\text { River Project Agricultural Improvement and Power District in Arizona, votes for } \\
\text { the Board of Directors are apportioned according to the size of land holdings) } \\
\text { - State authorities, such as the New York Power Authority and the South } \\
\text { Carolina Public Service Authority, are agencies of their respective State } \\
\text { governments }\end{array}$ \\
\hline $\begin{array}{l}\text { Cooperatively Owned Utilities } \\
\text { There are } 931 \text { cooperatively owned } \\
\text { utilities in the United States, and they } \\
\text { operate in all States except Connecticut, } \\
\text { Hawaii, Rhode Island, and the District of } \\
\text { Columbia. }\end{array}$ & $\begin{array}{l}\text { - Owned by members (small rura! farms and communities) } \\
\text { - Provide service mostly to members only } \\
\text { - Incorporated under State law and directed by an elected board of directors } \\
\text { - The Rural Utilities Service (formerly the Rural Electrification Administration) in } \\
\text { the U.S. Department of Agriculture was established under the Rural } \\
\text { Electrification Act of } 1936 \text { with the purpose of extending credit to cooperatives } \\
\text { to provide electric service to small rural communities (usually fewer than } 1,500 \\
\text { consumers) and farms where it was relatively expensive to provide service }\end{array}$ \\
\hline
\end{tabular}

Source: Energy Information Administration, Electric Power Annual 1995, Volume II, DOE/EIA-0348(95)/2 (Washington, DC, December 1996). 
Table 1. Number of Electric Utilities by Class of Ownership and NERC Region, 1995

\begin{tabular}{|c|c|c|c|c|c|}
\hline NERC Region ${ }^{a}$ & $\begin{array}{l}\text { Investor- } \\
\text { Owned }\end{array}$ & Federal & $\begin{array}{c}\text { State, } \\
\text { Municipal, } \\
\text { and Other } \\
\text { Government }\end{array}$ & Cooperative & Total \\
\hline ASCC $\ldots \ldots \ldots \ldots \ldots$ & 23 & 1 & 38 & 21 & 83 \\
\hline ECAR $\ldots \ldots \ldots \ldots \ldots$ & 43 & 0 & 226 & 109 & 378 \\
\hline ERCOT $\ldots \ldots \ldots \ldots \ldots$ & 6 & 0 & 66 & 59 & 131 \\
\hline MAIN $\ldots \ldots \ldots \ldots \ldots$ & 18 & 1 & 148 & 45 & 212 \\
\hline MAPP $\ldots \ldots \ldots \ldots \ldots$ & 14 & 0 & 489 & 183 & 686 \\
\hline NPCC $\ldots \ldots \ldots \ldots \ldots$ & 55 & 0 & 126 & 10 & 191 \\
\hline SERC $\ldots \ldots \ldots \ldots \ldots \ldots$ & 19 & 2 & 321 & 189 & 531 \\
\hline SPP $\ldots \ldots \ldots \ldots \ldots \ldots$ & 16 & 1 & 299 & 158 & 474 \\
\hline
\end{tabular}

aNERC is the North American Electric Reliability Council, formed in 1968 by the electric utility industry to promote the reliability and adequacy of bulk power supply in the electric utility systems of North America.

Note: See Figure 1 for a map of the regions.

Source: Energy Information Administration, Form EIA-861, “Annual Electric Utility Report” (1995).

Figure 1. North American Electric Reliability Council Regions for the Contiguous United States and Alaska

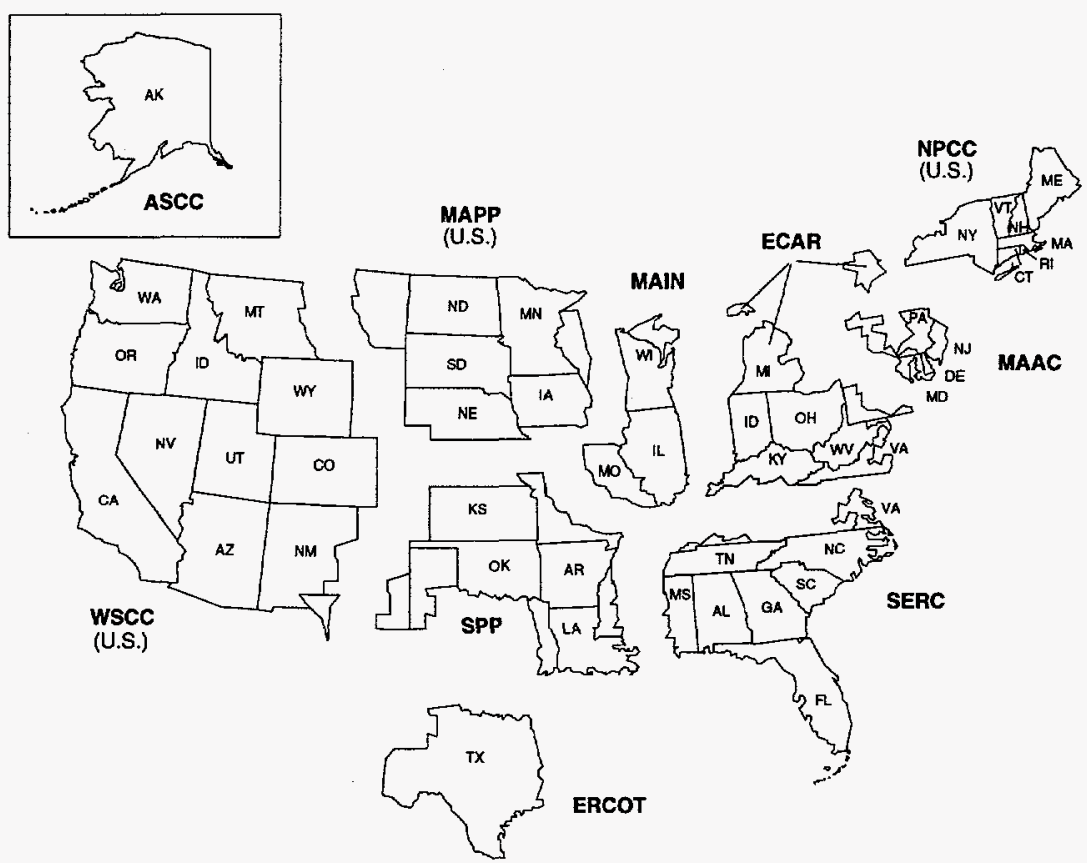

Regional Electric Area Council Areas: ECAR-East Central Area Reliability Coordination Agreement, SERC-Southeastern Electric Reliability Council, MAIN-Mid-American Interpool Network, SPP-Southwest Power Pool, ERCOT-Electric Reliability Council of Texas, MAAC-Mid-Atlantic Area Council, MAPP (U.S.)-Mid-Continent Area Power Pool, WSCC (U.S.)-Western Systems Coordinating Council, NPCC (U.S.)-Northeast Power Coordinating Council, ASCC-Alaska Systems Coordinating Council.

Source: North American Electric Reliability Council. 
Figure 2. Electric Utility Generation and Retail Sales by Ownership Category, 1995

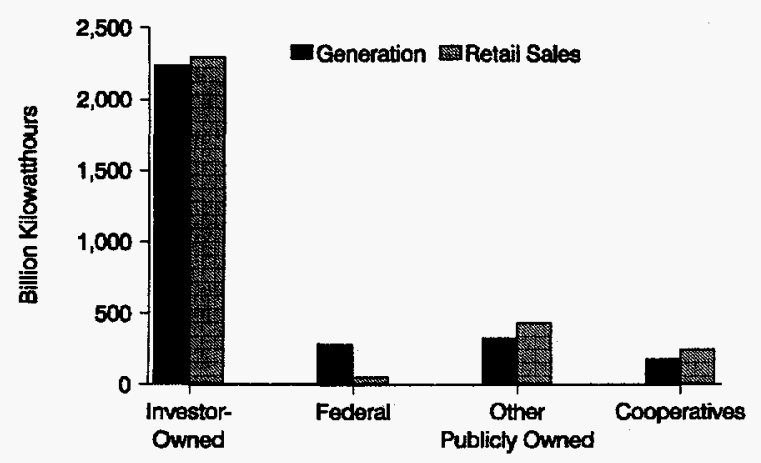

Source: Energy Information Administration, Form ElA861, “Annual Electric Utility Report” (1995).

- The Department of the Interior's U.S. Bureau of Reclamation

- The Department of State's International Water and Boundary Commission

- The Tennessee Valley Authority.

Of these, there are three major producers of electricity: the Tennessee Valley Authority (TVA); the U.S. Army Corps of Engineers (USCE); and the U.S. Bureau of Reclamation (USBR). The TVA is the largest Federal power producer, marketing its own power in both the wholesale and retail markets. Generation by the USCE, except for the North Central Division (Saint Mary's Falls at Sault Ste. Marie, Michigan), and by the USBR is marketed by four of the Federal power marketing administrations (PMAs) Bonneville, Southeastern, Southwestern, and Western Area. These four PMAs also purchase energy for resale from other electric utilities in the United States and Canada. Alaska, the fifth PMA, operates its own power plants and distributes power to ultimate consumers.

Federal power plants generated approximately 9 percent of total utility electricity in the United States in 1995, primarily from hydroelectric facilities. The Tennessee Valley Authority generates electricity from coal and nuclear power as well as hydropower. In 1995, only less than 2 percent of the utility generation was sold by Federal utilities to retail consumers. Consumers of Federal power are usually large industrial consumers or Federal installations. Most of the remaining energy generated by Federal utilities is sold in the wholesale market to publicly owned utilities and rural cooperatives for resale. These wholesale consumers have preference claims to Federal electricity. Only the surplus remaining after meeting the energy requirements of preference consumers is sold to investor-owned utilities.

\section{Other Publicly Owned Utilities}

Publicly owned electric utilities can be divided into generators and nongenerators. (In contrast, virtually all investor-owned electric utilities own and operate generating capacity.) Generators are those electric utilities that own and operate generating capacity to supply some or all of their customers' needs. However, some generators supplement their production by purchasing power. The nongenerators rely exclusively on power purchases. Their primary function is to distribute electricity to their consumers. The nongenerators comprise over half of the total number of publicly owned electric utilities.

In 1995, publicly owned utilities accounted for almost 63 percent of the number of electric utilities in the United States. They produced approximately 11 percent of total utility generation and accounted for 14 percent of utility sales to ultimate consumers. Other publicly owned utilities include municipal authorities, State authorities, public power districts, irrigation districts, and other State organizations. Municipal utilities tend to be concentrated in cities where the loads are small. They exist in every State except Hawaii, but most are located in the Midwest and Southeast. State authorities are utilities that function in a manner similar to Federal utilities. They generate or purchase electricity from other utilities and market large quantities in the wholesale market to groups of utilities within their States at lower prices than the individual utilities would otherwise pay. The publicly owned power districts are concentrated in Nebraska, Washington, Oregon, Arizona, and California. In general, publicly owned utilities tend to have lower costs than investor-owned utilities because they often have access to taxfree financing and do not pay certain taxes or dividends. They also have high-density service areas.

\section{Rural Electric Cooperatives}

Most rural electric cooperative utilities are formed and owned by groups of residents in rural areas to supply power to those areas. Some cooperatives may be owned by a number of other cooperatives. There are really three types of cooperatives: (1) distribution only; (2) distribution with power supply; and (3) generation and transmission. Cooperatives currently operate in 47 States, and they represent 29 percent of the total number of utilities in the country. Most distribution cooperatives resemble municipal utilities in that they often do not generate electricity, but purchase it from other utilities. The other type (generating and transmission cooperatives) 
are usually referred to as "power supply cooperatives." These cooperatives are usually owned by the distribution cooperatives to whom they supply wholesale power. Distribution cooperatives resemble Federal utilities, supplying electricity to other utility consumers from their generating capability. Cooperatives accounted for approximately 6 percent of total utility generation and 8 percent of utility sales to ultimate consumers in 1995.

\section{Nonutilities}

Nonutilities are privately owned entities that generate power for their own use and/or for sale to utilities and others. Nonutilities can be classified in two distinct ways. One approach separates nonutilities into separate categories based on their classification by FERC and the type of technology they employ: (1) cogenerators and (2) small power producers, both of which are qualifying facilities (QFs) because they meet certain criteria set forth by PURPA; (3) exempt wholesale generators, which are designated by FERC; (4) cogenerators not qualified under PURPA; and (5) noncogenerators not qualified under PURPA. ${ }^{17}$ QFs receive certain benefits under PURPA. ${ }^{18}$ In particular, they are guaranteed that electric utilities will purchase their output at a price based on the utility's "avoided cost." 19 The characteristics of and major differences among these categories of nonutilities are shown in the inset on page 14 .

A second approach for classifying nonutilities is based on the major industry group into which the nonutility company falls. Nonutility electricity generators are found in many different industries. In 1995, most nonutility generating capacity ( 68 percent) was in the manufacturing sector of the economy (Figure 3 ). Within the manufacturing sector, the chemical industry, with 33 percent of the manufacturing total, the paper industry, with 25 percent, and petroleum refining, with 14 percent, generate more electricity in their plants than all other manufacturing sectors combined. The manufacturing processes conducted at many of these plants can utilize the thermal energy produced when cogenerating electricity. ${ }^{20}$ After manufacturing, the largest portion of nonutility electricity generating capacity ( 21 percent) can be found in the electric, gas, and sanitary services sector. The entities that make up this sector are usually engaged primarily in producing, transporting, and/or distributing electricity, although they may be engaged primarily in steam, gas, water, and/or waste disposal services as a primary business. Unlike nonutilities in other sectors, these nonutilities are engaged primarily in activities similar to the generation activities carried out by electric utilities. The remaining nonutility capacity is found either in the mining industry ( 5 percent) or in various other industries, including agriculture, transportation, and other services (6 percent).

\section{Figure 3. Shares of Nonutility Nameplate Capacity by Major Industry Group, 1995}

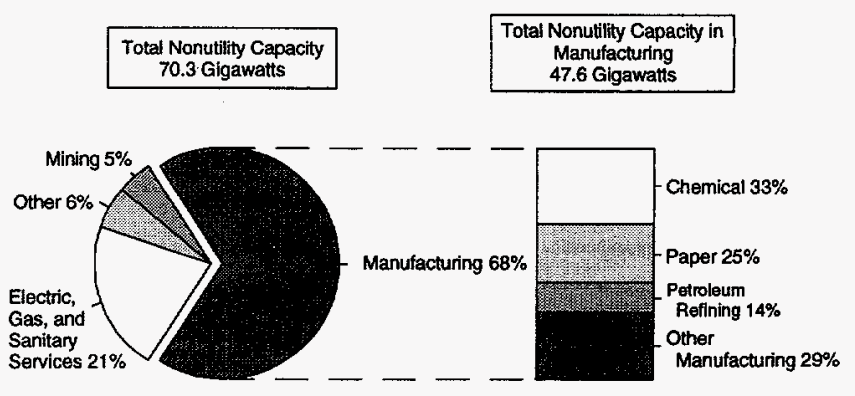

Note: Totals may not equal the sum of components due to independent rounding.

Source: Energy Information Administration, Form EIA867, “Annual Nonutility Power Producer Report” (1995).

\section{Recent Expansion of Utilities and Nonutilities}

There is a striking contrast between utilities and nonutilities, which can be seen by comparing their shares of total electricity generating capacity ${ }^{21}$ and net additions to capacity. Utilities have continued to dominate total generating capacity (Figure 4). Even by 1995, their share had only fallen to 91 percent. Utilities also continued to dominate additions to capacity through 1989 (Figure 5). However, in 1990, nonutilities added more capacity than utilities did. This situation continued through 1994,

\footnotetext{
${ }^{17}$ FERC designations are not mutually exclusive categories among themselves, but, as a group, they and the two nonqualifying categories are mutually exclusive.

${ }_{18}^{18}$ See Chapter 4 for a discussion of qualifying facilities under PURPA.

19 This concept is discussed further in Chapter 4.

${ }^{20}$ See Chapter 4 for a discussion of cogenerators.

${ }^{21}$ Capacity is the amount of electric power delivered or required for which a generator, turbine, transformer, transmission circuit, station, or system is rated by the manufacturer.
} 


\begin{tabular}{|c|c|}
\hline \multicolumn{2}{|c|}{ Major Characteristics of U.S. Nonutilities by Type } \\
\hline Type & Major Characteristics \\
\hline Cogenerators (QF) & $\begin{array}{l}\text { - Are qualified under PURPA by meeting certain ownership, operating, and } \\
\text { efficiency criteria established by FERC } \\
\text { - Sequentially produce electric energy and another form of energy, such as } \\
\text { heat or steam, using the same fuel source } \\
\text { - Are guaranteed that utilities will purchase their output at a price based on } \\
\text { the utility's "avoided cost" and will provide backup service at } \\
\text { nondiscriminatory rates }\end{array}$ \\
\hline Small Power Producers (QF) & $\begin{array}{l}\text { - Are qualified under PURPA by meeting certain ownership, operating, and } \\
\text { efficiency criteria, established by FERC } \\
\text { - Use biomass, waste, renewable resources (water, wind, solar), or } \\
\text { geothermal as a primary energy source } \\
\text { - Fossil fuels can be used but renewable resources must provide at least } 75 \\
\text { percent of the total energy input } \\
\text { - Are guaranteed that utilities will purchase their output at a price based on } \\
\text { the utility's "avoided cost" and will provide backup service at } \\
\text { nondiscriminatory rates }\end{array}$ \\
\hline Exempt Wholesale Generators & $\begin{array}{l}\text { Creation authorized by EPACT } \\
\text { - Are exempt from PUHCA's corporate and geographic restrictions } \\
\text { - Are wholesale producers; do not sell retail } \\
\text { - Ut not possess significant transmission facilities } \\
\text { - Are regulated but usually may charge market-based rates }\end{array}$ \\
\hline Cogenerators (Non-QF) & $\begin{array}{l}\text { - Are not qualified under the provisions of PURPA } \\
\text { - Are nonutilities, utilizing a cogenerating technology, which may themselves } \\
\text { consume part of the electricity they cogenerate }\end{array}$ \\
\hline $\begin{array}{l}\text { Noncogenerators } \\
\text { (Non-QF) }\end{array}$ & $\begin{array}{l}\text { - Are not qualified under the provisions of PURPA } \\
\text { - Do not utilize a cogenerating technology }\end{array}$ \\
\hline \multicolumn{2}{|c|}{$\begin{array}{l}\text { QF = Qualifying facility (under PURPA). } \\
\text { Note: An entity can be any combination of cogenerator QF, small power producer QF, and exempt wholesale generator. } \\
\text { Source: Energy Information Administration, Electric Power Annual 1995, Volume II, DOE/EIA-0348(95)/2 (Washington, } \\
\text { DC. December 1996). }\end{array}$} \\
\hline
\end{tabular}

\section{Electric Power versus Electric Energy}

Electric power is the rate at which electricity does work. It is measured at a point in time and has no time dimension. The maximum amount of electric power that a piece of electrical equipment can accommodate is its capacity or capability. Its basic unit of measure is a watt.

Electric energy is the amount of work that can be done by electricity, i.e., it is the amount of electric power produced or used over a specific time period. It is measured over a period of time and has a time dimension as well as an energy dimension. The amount of electric energy produced or used during a specified period of time by a piece of electrical equipment is its generation or consumption. Its basic unit of measure is a watthour. 
Figure 4. Utility and Nonutility Nameplate Capacity, 1985-1995

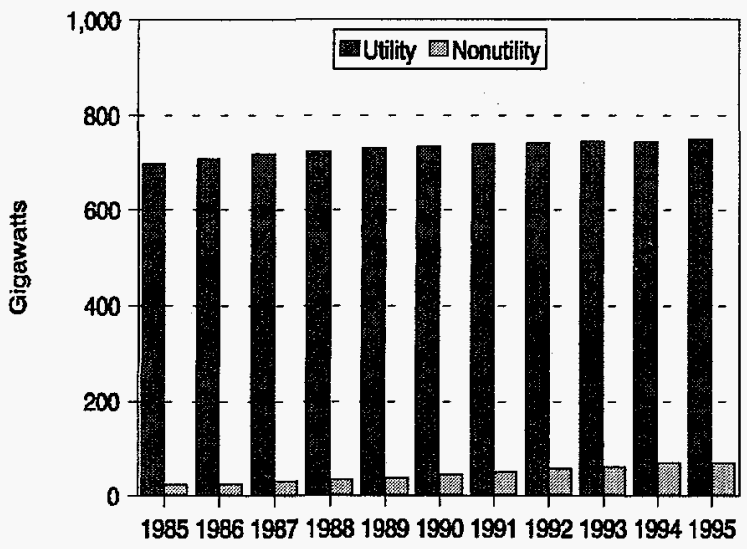

Source: Utility data: Energy Information Administration (EIA), Inventory of Power Plants in the United States 1995, DOE/EIA-0095(95) (Washington, DC, December 1996), Table 1 (and previous issues); Nonutility data 1985-1988: Edison Electric Institute, Statistical Yearbook of the Electric Utility Industry 1991 (Washington, DC, October 1992), pp. 7 and 15; Nonutility data 1989-1995: ElA, Electric Power Annual 1995, Volume II, DOE/EIA-0348(95)/2 (Washington, DC, December 1996), Table 52 (and previous issues).

but in 1995, utilities again added more capacity than nonutilities. Another perspective for comparing utilities and nonutilities is provided by looking at planned additions to capacity. Utilities plan to add more capacity than nonutilities in each of the next 3 years (Figure 6), ${ }^{22}$ but the restructuring of the industry that is now going on tends to engender uncertainty about those plans.

The electric power industry has been dominated by utilities-most importantly, regulated investor-owned utilities. But nonutilities have been increasing their role in the industry. This began with PURPA, when nonutilities were seen as an energy-efficient, environment-friendly source of electricity. Their role has continued to grow as nonutilities have come to be seen as an economically efficient, possibly competitive alternative to monopoly utilities. Many industry observers expect the role of nonutilities to continue to grow. ${ }^{23}$

The amounts of energy generated by each component of utilities and nonutilities in 1995 are compared with the amounts generated in 1985 in Figure 7. Juxtaposing

\section{Figure 5. Utility and Nonutility Net Additions to Nameplate Capacity, 1986-1995}

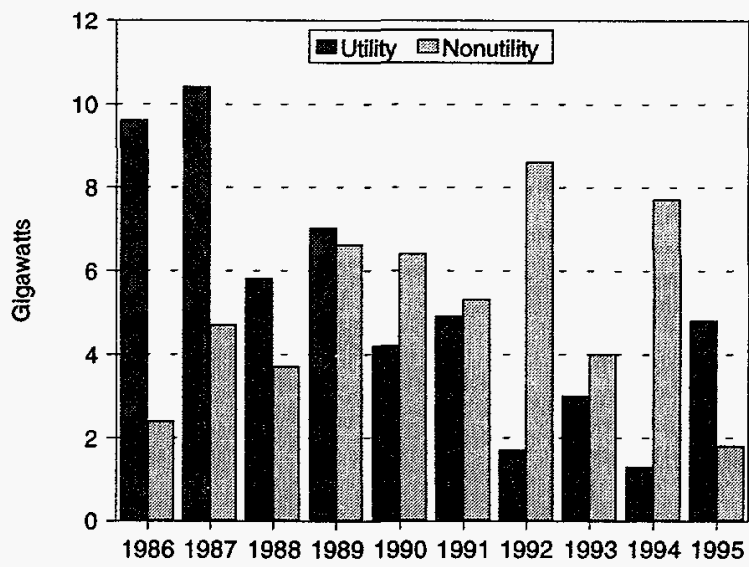

Sources: Utility data: Energy Information Administration (EIA), Inventory of Power Plants in the United States 1995 DOE/EIA-0095(95) (Washington, DC, December 1996), Table 1 (and previous issues); Nonutility data 1986-1989: Edison Electric Institute; Statistical Yearbook of the Electric Utility Industry 1991 (Washington, DC, October 1992), pp. 7 and 15; Nonutility data 1990-1995: EIA, Electric Power Annual 1995, Volume II, DOE/EIA-0348(95)/2 (Washington, DC, December 1996), Table 52 (and previous issues).

shares of generation gives those not familiar with the supply side of the industry a better perspective on the relative position each component holds in the electricity supply arena. This figure is also an excellent indicator of the significant amount of change that has occurred in the nonutility segment of the industry.

\section{The Interconnected Networks}

The U.S. bulk power system has evolved into three major networks (power grids), which also include smaller groupings or power pools. The major networks consist of extra-high-voltage connections between individual utilities designed to permit the transfer of electrical energy from one part of the network to another. These transfers are restricted, on occasion, because of a lack of contractual arrangements or because of inadequate transmission capability.

The three networks are (1) the Eastern Interconnected System, consisting of the eastern two-thirds of the United

\footnotetext{
${ }^{22}$ Two caveats regarding planned capacity additions should be kept in mind. Utilities must plan to build to meet expected demand; nonutilities have no such requirement. Planned additions are not net of planned retirements, so they give an incomplete picture of changes in total capacity.

${ }^{23}$ For example, see Energy Information Administration, Annual Energy Outlook 1996, DOE/EIA-0383(96) (Washington, DC, January 1996), p. 29.
} 
Figure 6. Utility and Nonutility Planned Additions to Nameplate Capacity, 1996-1998

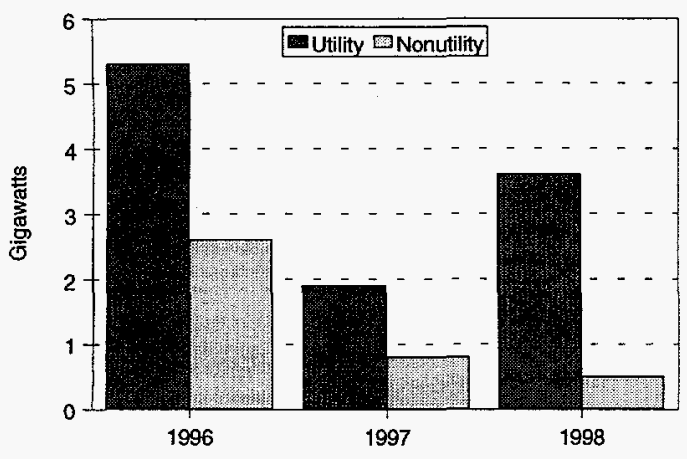

Note: Indefinitely postponed and canceled units are not included.

Source: Utility data: Energy Information Administration, Inventory of Power Plants in the United States 1995, DOE/EIA0095(95) Washington, DC, December 1996). Nonutility data: Energy Information Administration, Form ElA-867, “Annual Nonutility Power Producer Report" (1995).

States; (2) the Western Interconnected System, consisting primarily of the Southwest and areas west of the Rocky Mountains; and (3) the Texas Interconnected System (Figure 8). The latter is not interconnected with the other two networks (except by certain direct current lines). The other two networks have limited interconnections to each other. Both the Western and the Texas Interconnect are linked with different parts of Mexico. The Eastern and Western Interconnects are completely integrated with most of Canada or have links to the Quebec Province power grid. Virtually all U.S. utilities are interconnected with at least one other utility by these three major grids. The exceptions are in Alaska and Hawaii. The interconnected utilities within each power grid coordinate operations and buy and sell power among themselves.

The bulk power system makes it possible for utilities to engage in wholesale (for resale) electric power trade. Wholesale trade has historically played an important role, allowing utilities to reduce power costs, increase power supply options, and improve reliability. ${ }^{24}$ In quantity, it accounts for more than one-half of electricity sales to ultimate consumers. Since 1986, the total amount of wholesale power trade (as measured by purchased power plus exchange received) among utilities and nonutilities has grown at an average annual rate of 2.7 percent, ${ }^{25}$ which is the same as the rate of growth for retail sales by utilities. In the past, wholesale trade has been dominated by utility purchases from other utilities. In 1995, utilities purchased a total of 1,283 billion kilowatthours of wholesale electricity from other utilities and a smaller but increasing amount (222 billion kilowatthours) from nonutility producers (Figure 9 ).

Wholesale power sales by nonutilities to utilities and wheeling (the transmission of power from one point to another) by utilities have both grown vigorously. Wholesale sales by nonutilities grew from 40 to 222 billion kilowatthours between 1986 and 1995, which yields an average annual growth rate over the period of 21.0 percent. Wheeling, ${ }^{26}$ while not increasing as spectacularly, grew at an annual average rate of 6.9 percent over the same period, a rate that is 2.5 times the growth rate for sales to ultimate consumers. Whether these rates will be sustained is uncertain, and more recent evidence is not encouraging. Utility sales to ultimate consumers, wholesale sales by nonutilities, and wheeling by utilities all grew more slowly between 1990 and 1995, with annual growth rates of 2.1, 13.9, and 2.0 percent, respectively.

Even more dramatic is the growth in wholesale trade between regions of the National Electric Reliability Council (NERC). Historically, almost all wholesale trade was within NERC regions, but utilities are expanding wholesale trade beyond its traditional boundaries. Between 1988 and 1994, one part of interregional wholesale trade, purchases of electricity by investorowned utilities, doubled its share of total wholesale purchases from 5.0 to 10.1 percent.

In recent years, U.S. international trade in electricity has returned to the levels of the mid-1980s (Figure 10). U.S. trade is mostly imports, which were more than five times greater than exports in 1995. Normally, most imports are from Canada (95 percent of total gross imports in 1995) and the remainder is from Mexico. Imported power is particularly important to the NPCC and MAPP regions of NERC, where gross imports were 9.8 and 7.7 percent, respectively, of retail sales by utilities in 1995 . In contrast, gross imports for the Nation as a whole that year were 1.6 percent of retail sales by utilities.

Overall reliability planning and coordination of the interconnected power systems are the responsibility of NERC, which was voluntarily formed in 1968 by the

\footnotetext{
${ }^{24}$ For an in-depth study on the issue of U.S. electric power system reliability, refer to Energy Information Administration, Performance Issues for a Changing Electric Power Industry, DOE/EIA-0586 (Washington, DC, January 1995).

${ }^{25}$ Energy Information Administration, Electric Power Annual 1995, Volume II, DOE/EIA-0348(95)/2 (Washington, DC, December 1996), Table 36 (and previous issues).

${ }^{26}$ As measured by wheeling delivered.
} 
Figure 7. Utility and Nonutility Generation and Shares by Class, 1985 and 1995

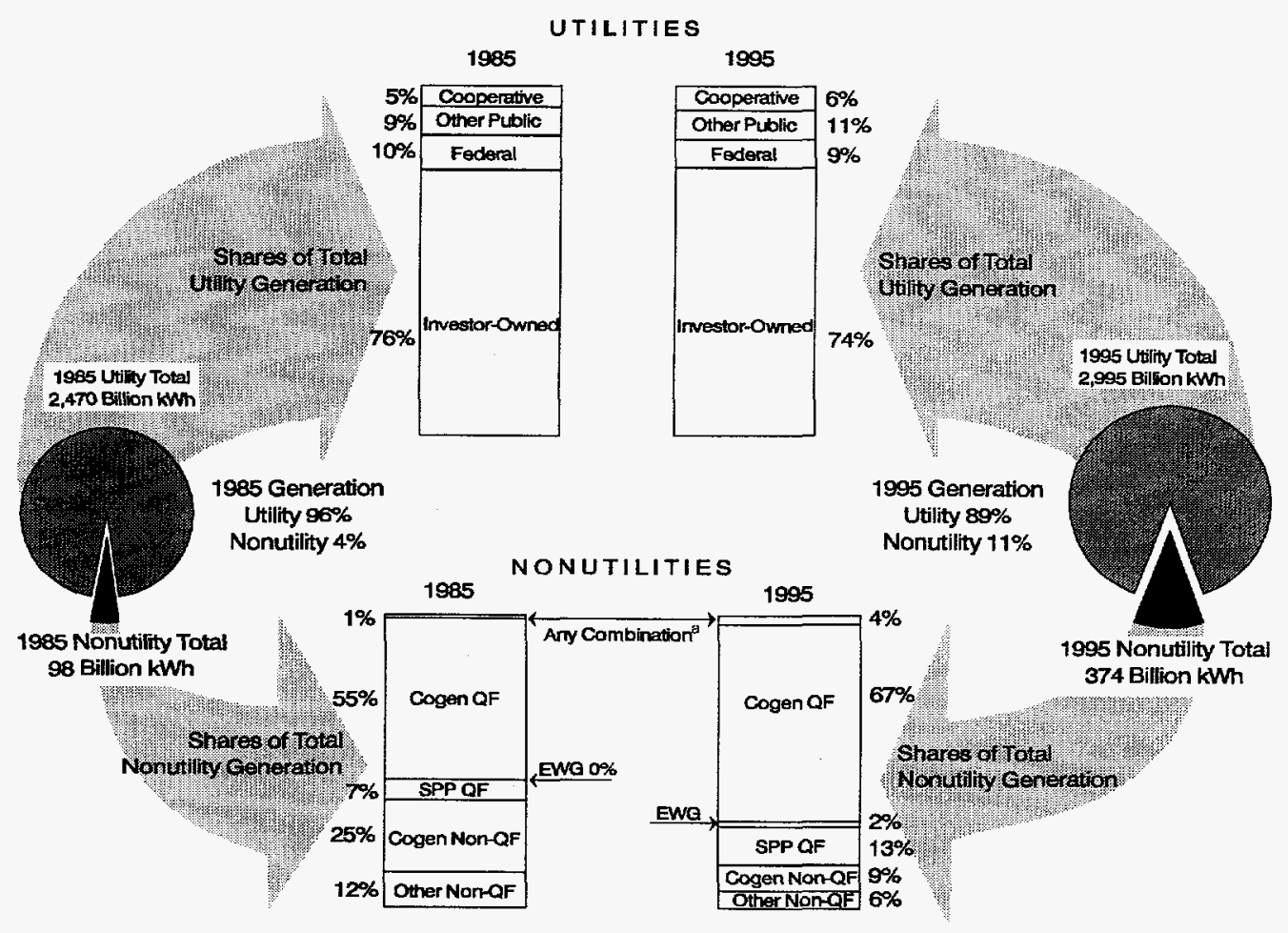

ancludes facilities classified in more than one of the following FERC designated categories: cogenerator QF, small power producer QF, or exempt wholesale generator.

Cogen = Cogenerator.

EWG $=$ Exempt wholesale generator.

Other Non-QF = Noncogenerator Non-QF.

QF = Qualifying facility.

SPP $=$ Small power producer.

Note: •Sum of components may not equal total due to independent rounding. •Classes for nonutility generation are determined by the class of each generating unit.

Source: Utility data: Energy Information Administration (EIA), Form ElA-861, "Annual Electric Utility Report" (1995), and EIA, Electric Power Annual 1995, Volume I, DOE/EIA-0348(95)/1 (Washington, DC, July 1996), Table 8 (and previous issues);1985 nonutility data: Shares of generation estimated by EIA; total generation from Edison Electric Institute, Statistical Yearbook of the Electric Utility Industry 1991 (Washington, DC, November 1992); 1995 nonutility data: EIA, Form ElA-867, “Annual Nonutility Power Producer Report" (1995).

electric utility industry as a result of the 1965 power failure in the Northeast. NERC's nine regional councils cover the 48 contiguous States, part of Alaska, ${ }^{27}$ and portions of Canada and Mexico. The councils are responsible for overall coordination of bulk power policies that affect the reliability and adequacy of service in their areas. They also regularly exchange operating and planning information among their member utilities. The boundaries of the NERC regions follow the service areas of the electric utilities in the region, many of which do not follow State boundaries.
At present, the industry is in transition. Steady progress toward competitive wholesale markets for electric power recently has been accelerated by FERC Order 888 , which opens access to transmission lines and encourages greater wholesale trade. In addition, the States are considering opening retail markets to competition, and many are in different stages of experimenting with this concept (see Part II of this report). The following chapter summarizes the legislative history that has paved the way for the issuance of Order 888 and the industry's pending move to a competitive market environment.

${ }^{27}$ The Alaska System Coordinating Council was an associate member of NERC in 1988 and now they are a member. 
Figure 8. Regions and Interconnections of the North American Electric Reliability Council in the Contiguous United States

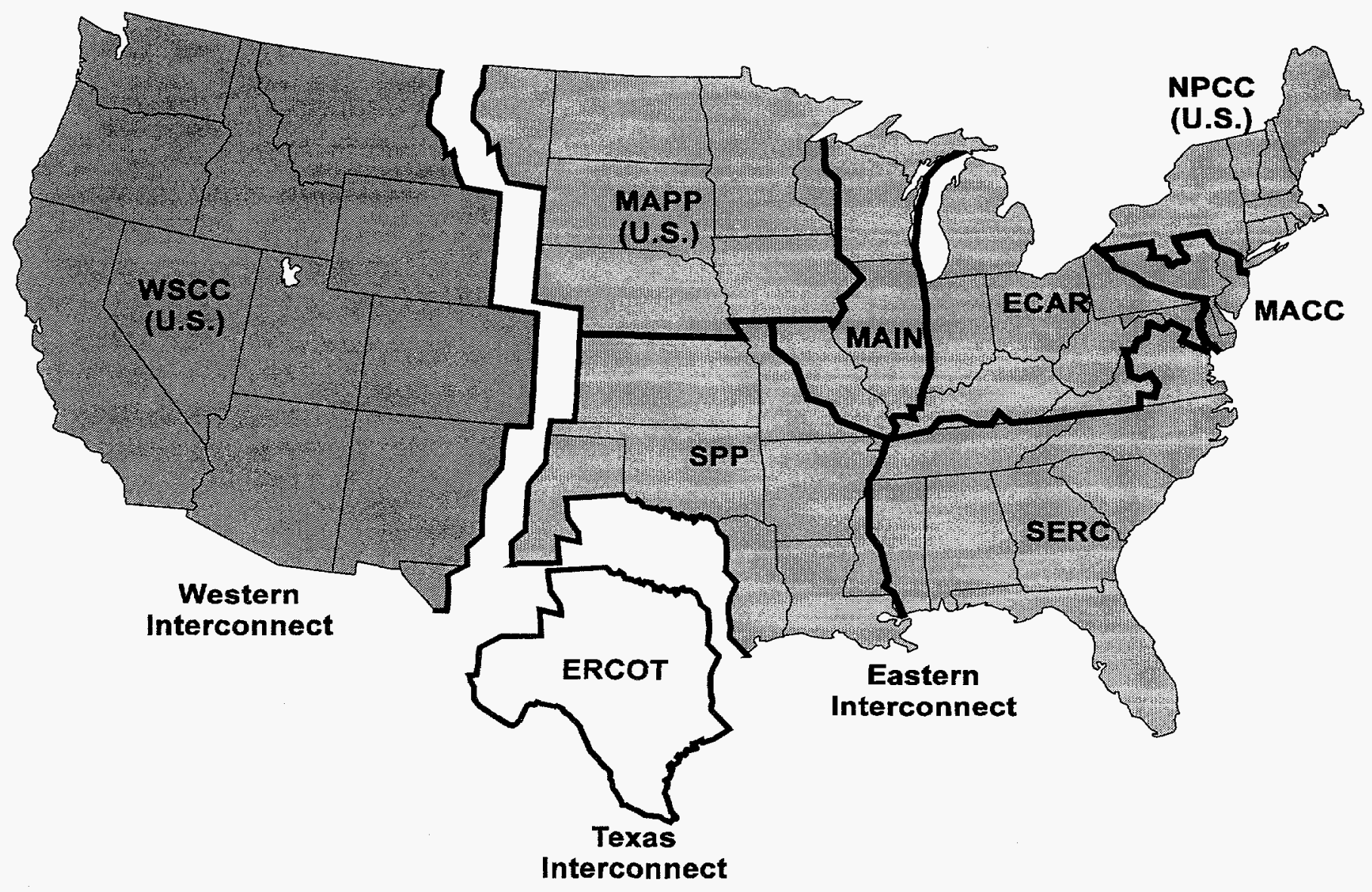

Regional Electric Reliability Council Areas:
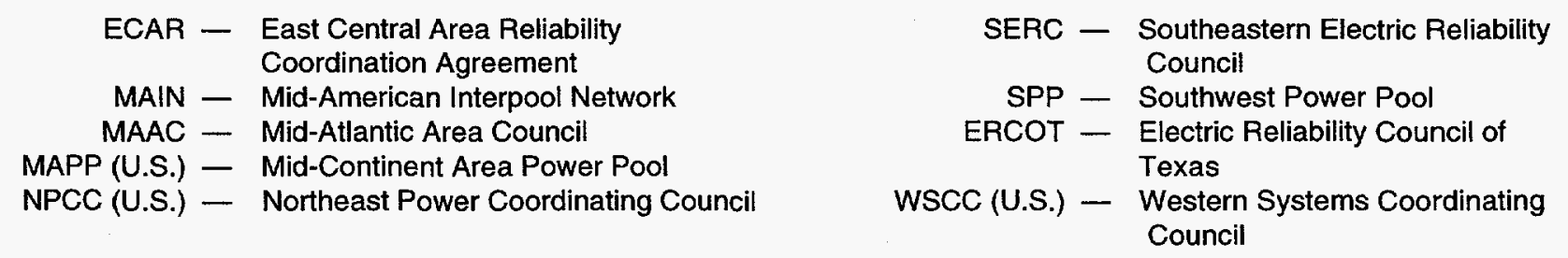

Source: North American Electric Reliability Council. 
Figure 9. Electric Utility Wholesale Power Purchases by Ownership Type, 1995 (Billion Kilowatthours)

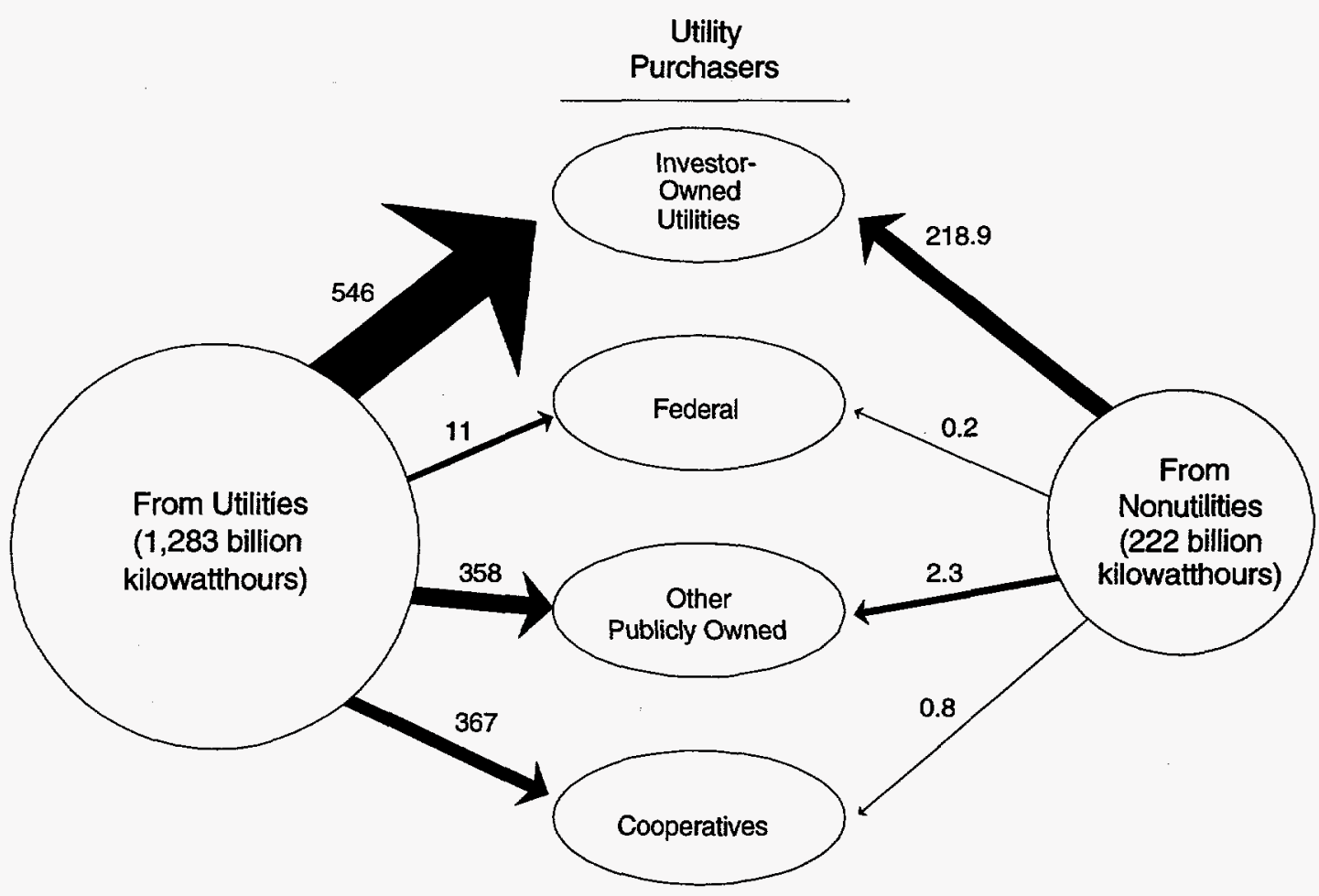

Note: Totals may not equal sum of components due to independent rounding.

Source: Energy Information Administration, Form EIA-861, "Annual Nonutility Power Producer Report" (1995).

Figure 10. U.S. International Electricity Trade, 1985-1995

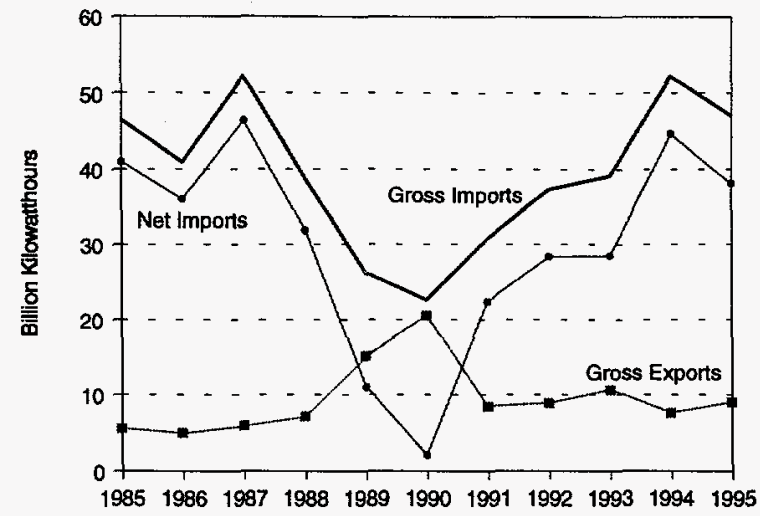

Source: 1985-1994: Energy Information Administration, Annual Energy Review 1995, DOE/EIA-0384(95) (Washington, DC, July 1996), Table 8.1. 1995: Energy Information Administration, Electric Power Annual 1995, Volume II, DOE/EIA-0348(95)/2 (Washington, DC, December 1996), Tables 40-42. 



\section{Federal Legislative Impacts}

This chapter describes Federal legislation that has had major impacts on the electric power industry. The inset below lists and summarizes the laws that have shaped the industry since the 1930s. The remainder of the chapter will focus on three Acts that have had profound effects on the industry's structure-the Public Utility Holding Company Act of 1935 (PUHCA), the Public Utility Regulatory
Policies Act of 1978 (PURPA), and the Energy Policy Act of 1992 (EPACT). The features of EPACT that led to FERC Orders 888 and 889 are discussed. (PUHCA and PURPA have recently been targeted for repeal. Chapter 6 will address the issues and arguments associated with the call for repeal, as well as current proposals for restructuring legislation that are before Congress.)

\section{Major Federal Legislation Affecting the Electric Power Industry}

Tennessee Valley Authority Act of 1933

(Public Law 73-17)

Under this law, the Federal Government provided electric power to States, counties, municipalities, and nonprofit cooperatives. It was the steady continuation of Federal responsibility to adopt navigation, flood control, strategic materials for national defense, electric power, relief of unemployment, and improvement of living conditions in rural areas. The Tennessee Valley Authority (TVA) was also authorized to generate, transmit, and sell electric power. With regard to the sale of electric power, the TVA is authorized to enter into contracts up to 20 years for sales to governmental and private entities, to construct transmission lines to areas not otherwise supplied with electricity, to establish rules and regulations for power sales and distribution, and to acquire existing electric facilities used in serving certain areas.

Public Utility Holding Company Act of 1935 (PUHCA)

(Public Law 74-333)

PUHCA was enacted to break up the large and powerful trusts that controlled the Nation's electric and gas distribution networks. PUHCA gave the Securities and Exchange Commission the authority to break up the trusts and to regulate the reorganized industry in order to prevent their return.

Federal Power Act of 1935 (Title II of PUHCA)

(Aug. 26, 1935, ch. 687, Title II, 49 Stat. 838)

This Act was passed to provide for a Federal mechanism, as required by the Commerce Clause of the Constitution, for interstate electricity regulation.

\section{Rural Electrification Act of 1936}

(Public Law 74-605)

This Act established the Rural Electrification Administration (REA) to provide loans and assistance to organizations providing electricity to rural areas and towns with populations under 2,500. REA cooperatives are generally associations or corporations formed under State law. The predecessor to this Act was the Emergency Relief Appropriations Act of 1935, which performed the same function.

Bonneville Project Act of 1937

(Public Law 75-329)

This Act created the Bonneville Power Administration (BPA), which pioneered the Federal power marketing administrations. The BPA was accountable for the transmission and marketing of power produced at Federal dams in the Northwest. In 1953, the BPA first guaranteed the bonds of and a market for small energy facilities built and financed by public utility districts. 


\section{Major Federal Legislation Affecting the Electric Power Industry (Continued)}

Reclamation Project Act of 1939

(Aug. 4, 1939, ch. 418, 53 Stat. 1187)

This Act requires that rates for electric power generated at Federal hydroelectric projects be adequate to recover the powerrelated share of construction costs, to include interest charged at a rate of not less than 3 percent.

\section{Flood Control Act of 1944}

(Dec. 22, 1944, ch. 665, 58 Stat. 887)

This Act formed the basis for the later creation of the Southeastern Power Administration (SEPA) in 1950 to sell power produced by the U.S. Army Corps of Engineers in the Southeast; and the Alaska Power Administration (APA) ${ }^{b}$ in 1967 to both operate and market power from two hydroelectric plants in Alaska: the Eklutna Project and the Snettisham Project. Although the Southwestern Power Administration's (SWPA) ${ }^{c}$ authority after World War II came from the Flood Control Act of 1944, it was established using the Executive Branch's emergency war powers authority to satisfy the growing demands from weapons development and domestic needs. This Act also demands that rates for electric power be enough to recover the cost of "producing and transmitting such electric energy."."

First Deficiency Appropriation Act of 1949

(Public Law 81-71)

The Act authorized the Tennessee Valley Authority to construct thermal-electric power plants for commercial electricity sale.

Energy Supply and Environmental Coordination Act of 1974 (ESECA)

(Public Law 93-319)

This Act allowed the Federal Government to prohibit electric utilities from burning natural gas or petroleum products.

\section{DOE Organization Act of 1977}

(Public Law 95-91)

In addition to forming the Department of Energy, this Act provided authority for the establishment of the Western Area Power Administration (WAPA) ${ }^{e}$ and transferred power marketing responsibilities and transmission assets previously managed by the Bureau of Reclamation to WAPA. WAPA's authority was extended through the Hoover Power Plant Act of 1984. This Act also transferred the other four power marketing administrations (PMA)--the Southeastern Power Administration, the Southwestern Power Administration, the Alaska Power Administration, and the Bonneville Power Administration-from the Department of the Interior to the Department of Energy.

National Energy Act of 1978

(Public Law 95-617 - 95-621)

This Act was signed into law in November 1978 and includes five different statutes: the Public Utility Regulatory Policies Act (PURPA), the Energy Tax Act (Public Law 95-618), the National Energy Conservation Policy Act (Public Law 95-619), the Powerplant and Industrial Fuel Use Act (Public Law 95-620), and the Natural Gas Policy Act (Public Law 95-621). Passed as a result of the Arab oil-producing nations' ban on oil exports to the United States, its general purpose was to ensure sustained economic growth while also permitting the economy time to make an orderly transition from the past era of inexpensive energy resources to a period of more costly energy.

Public Utility Regulatory Policies Act of 1978 (PURPA)

(Public Law 95-617)

PURPA was passed in response to the unstable energy climate of the late 1970s. PURPA sought to promote conservation of electric energy. Additionally, PURPA created a new class of nonutility generators, small power producers, from which, along with qualified cogenerators, utilities are required to buy power. 


\section{Major Federal Legislation Affecting the Electric Power Industry (Continued)}

Energy Tax Act of 1978 (ETA)

(Public Law 95-618)

This Act, like PURPA, was passed in response to the unstable energy climate of the 1970s. The ETA encouraged conversion of boilers to coal and investment in cogeneration equipment and solar and wind technologies by allowing a tax credit on top of the investment tax credit. It was later expanded to include other renewable technologies. However, the incentives were curtailed as a result of tax reform legislation in the mid-1980s.

National Energy Conservation Policy Act of 1978

(Public Law 95-619)

This Act required utilities to provide residential consumers free conservation services to encourage slower growth of electricity demand.

Powerplant and industrial Fuel Use Act of 1978

(Public Law 95-620)

This Act succeeded the Energy Supply and Environmental Coordination Act of 1974, and extended Federal prohibition powers.

Pacific Northwest Electric Power Planning and Conservation Act of 1980

(Public Law 96-501)

This Act created the Pacific Northwest Electric Power and Conservation Council to coordinate the operations of the Bonneville Power Administration (BPA). FERC approval is required for rates established under this Act. This Act also gave the BPA the authority to plan for and acquire additional power to meet its growing load requirements.

Economic Recovery Tax Act of 1981

(Public Law 97-34)

This Act introduced a new methodology for determining allowable tax depreciation deductions. The new methodology, the Accelerated Cost Recovery System (ACRS), set forth rules enabling taxpayers to claim generous depreciation deductions based on the system's permitted depreciable life, method, and salvage value assumptions. The generation, transmission, and distribution plant of regulated electric utilities was categorized as public utility property. Public utility property under ACRS was assigned relatively long depreciable lives.

Electric Consumers Protection Act of 1986 (ECPA)

(Public Law 99-495)

This Act was the first significant amendment to the hydro licensing provisions of the FPA since 1935. "The amendments have made four principal changes to Part I of the FPA. First, the municipal preference on relicensing has been eliminated. Second, the importance of environmental considerations in the licensing process has been greatly increased and the role of the State and Federal fish and wildlife agencies is expanded. Third, PURPA benefits for hydroelectric projects at new dams and diversions were eliminated unless the projects satisfy stringent environmental conditions. Finally, the FERC's enforcement powers have been increased substantially."

Tax Reform Act of 1986

(Public Law 99-509)

Under this Act, ACRS was replaced with the Modified Accelerated Cost Recovery System (MACRS). Under MACRS, the disparity in treatment of property between regulated and nonregulated taxpayers was eliminated. The investment credit was also repealed. The investment credit of the Federal income tax law was a dollar-to-dollar offset against the taxes payable by the taxpayer. The investment credit was available for regulated and nonregulated taxpayers and was intended to encourage capital investment by the Nation's businesses. The credit continues to be of importance to regulated utilities, however, because it is generally amortized for ratemaking and financial reporting purposes over the regulatory life of the related property that gave rise to the credit. 


\section{Major Federal Legislation Affecting the Electric Power Industry (Continued)}

Clean Air Act Amendments of 1990 (CAAA)

(Public Law 101-549)

These Amendments established a new emissions-reduction program. The goal of the legislation was to reduce annual sulfur dioxide emissions by 10 million tons and annual nitrogen oxide emissions by 2 million tons from 1980 levels for all man-made sources. Generators of electricity will be responsible for large portions of the sulfur dioxide and nitrogen oxide reductions. The program instituted under the Clean Air Act Amendments of 1990 employs a unique, market-based approach to sulfur dioxide emission reductions, while relying on more traditional methods for nitrogen oxide reductions.

\section{Energy Policy Act of 1992 (EPACT)}

(Public Law 102-486)

This Act created a new category of electricity producer, the exempt wholesale generator, which narrowed PUHCA's restrictions on the development of nonutility electricity generation. The law also mandated that FERC open up the national electricity transmission system to wholesale suppliers on a case-by-case basis.

aSEPA markets power in West Virginia, Virginia, North Carolina, South Carolina, Georgia, Florida, Alabama, Mississippi, Tennessee, and Kentucky. SEPA is unique from the other marketing authorities because it does not own any transmission lines.

'The APA and the TVA are the only two Federal marketing organizations that operate their own plants.

'SWPA markets power in Arkansas, Kansas, Louisiana, Missouri, Oklahoma, and Texas.

${ }^{d}$ Energy Information Administration, Financial Statistics of Major U.S. Publicly Owned Electric Utilities 1994, DOE/EIA0437(94)/2 (Washington, DC, December 1995), p. 458.

'The territory served by WAPA includes 15 Central and Western States of Arizona, California, Colorado, lowa, Kansas, Minnesota, Montana, Nebraska, Nevada, New Mexico, North Dakota, South Dakota, Texas, Utah, and Wyoming. The WAPA's authority was lengthened through the Hoover Power Plant Act of 1984 to constrain customer utilities to address certain conservation activities and to retain a part of customers' power allocations if they did not follow.

'D. J. Muchow and W. A. Mogel, Energy Law and Transactions (Matthew Bender, April 1996), p. 53-20.

Note: Although it is not a law, the Uniform Division of Income for Tax Purposes Act (UDITPA)-which provides that the sale of electricity is sourced for apportionment purposes to the ultimate destination State- has been adopted in some form by 44 States from a total of 47 States that impose a corporate income tax. Public laws before 1935 were sourced differently than those after 1935. For more information on the power marketing administrations, refer to Energy Information Administration, Financial Statistics of Major U.S. Publicly Owned Electric Utilities 1994, DOE/EIA-0437(94)/2 (Washington, DC, December 1995).

Source: This inset is based on information compiled by the Office of Coal, Nuclear, Electric and Alternate Fuels from various documents. These documents include Congressional Quarterly as well as others published by the following organizations: the Congressional Research Service, Government Institutes, Inc., the Council on Environmental Quality, the General Accounting Office, and the Federal Energy Regulatory Commission. Also refer to D. J. Muchow and W. A. Mogel, Energy Law and Transactions (Matthew Bender, April 1996).

\section{The Public Utility Holding Company Act of 1935}

The Public Utility Holding Company Act (PUHCA), enacted in 1935, was aimed at breaking up the unconstrained and excessively large trusts that then controlled the Nation's electric and gas distribution networks. They were accused of many abuses, including "control of an entire system by means of a small investment at the top of a pyramid of companies, sale of services to subsidiaries at excessive prices, buying and selling properties within the system at unreasonable prices, intra-system loans at unfair terms, and the wild bidding war to buy operating companies. ${ }^{\prime 28}$ The Act was passed at a time when financial pyramid schemes were extensive. These schemes allowed operating utilities in many areas of the country to come under the control of a small number of holding companies, which were in turn owned by other holding companies. These pyramids were sometimes ten layers thick. The following excerpt from America's Electric Utilities: Past, Present and Future demonstrates the complexities that resulted from the leveraging that took place within the holding company systems.

${ }^{28}$ L. S. Hyman, America's Electric Utilities: Past, Present and Future, Fifth Edition (Arlington, VA: Public Utilities Reports, Inc., 1994$)$, p. 111. 
The Insull ${ }^{29}$ interests [which operated in 32 states and owned electric companies, textile mills, ice houses, a paper mill, and a hotel] controlled 69 percent of the stock of Corporation Securities and 64 percent of the stock of Insull Utility Investments. Those two companies together owned 28 percent of the voting stock of Middle West Utilities. Middle West Utilities owned eight holding companies, five investment companies, two service companies, two securities companies, and 14 operating companies. It also owned 99 percent of the voting stock of National Electric Power. National, in turn, owned one holding company, one service company, one paper mill, and two operating companies. It also owned 93 percent of the voting stock of National Public Service. National Public Service owned three building companies, three miscellaneous firms, and four operating utilities. It also owned 100 percent of the voting stock of Seaboard Public Service. Seaboard Public Service owned the voting stock of five utility operating companies and one ice company. The utilities, in turn, owned eighteen subsidiaries. ${ }^{30}$

“Some holding companies were solid operations run for no other purpose than to coordinate and make efficient the operation of the subsidiary companies. But the holding company movement became a craze because of the promotional profits to be made. The holding companies were condemned and fell because of the excesses committed. The present structure of the electric utility industry is the direct result of legislation designed to destroy the holding company that did not have an operating rationale for its existence. As promoters saw the huge profits to be gained from the holding company business, they began to bid against each other to buy operating properties to put into the holding companies. Sometimes the promoters had to resort to odd measures to make things look good. One could, for instance, combine electric and ice properties, hiding the fact that most of the earnings were coming from the competitive, unsafe, and dwindling ice business. A good promoter could put together a combination of companies, sell preferred stock and bonds to the public to pay for the properties, take 10 percent or more as a commission, and keep the bulk (or all) of the voting common stock of the holding company, thereby remaining in control without having paid a cent into the business." ${ }^{31}$

Before PUHCA, almost half of all electricity generated in the United States was controlled by three huge holding companies, and more than 100 other holding companies existed. $^{32}$ The size and complexity of these huge trusts made industry regulation and oversight control by the States impossible. After the collapse of several large holding companies, the Federal Trade Commission (FTC) conducted an investigation after which it criticized the many abuses that tended to raise the cost of electricity to consumers. The Securities and Exchange Commission (SEC) also investigated and "publicly charged that the holding companies had been guilty of '... stock watering and capital inflation, manipulation of subsidies, and improper accounting practices.' The general counsel of the FTC went further, claiming that '[w]ords such as fraud, deceit, misrepresentation, dishonesty, breach of trust, and oppression are the only suitable terms to apply." "

Under PUHCA, the SEC was charged with the administration of the Act and the regulation of the holding companies. One of the most important features of the Act was that the SEC was given the power to break up the massive interstate holding companies by requiring them to divest their holdings until each became a single consolidated system serving a circumscribed geographic area. Another feature of the law permitted holding companies to engage only in business that was essential and appropriate for the operation of a single integrated utility. This latter restriction practically eliminated the participation of nonutilities in wholesale electric power sales. The law contained a provision that all holding companies had to register with the SEC, which was authorized to supervise and regulate the holding company system. Through the registration process, the SEC decided whether the holding company would need to be regulated under or exempted from the requirements of the Act. The SEC also was charged with regulating the issuance and acquisition of securities by holding companies. Strict limitations on intrasystem transactions and political activities were also imposed..$^{34}$

29 Samuel Insull worked for Thomas Edison and later became the vice-president of Edison General Electric Company. In 1887, Insull established the Chicago Edison Co., and in 1897 Commonwealth Electric was formed. In 1907, Insull consolidated Chicago Edison and Commonwealth Electric to form Commonwealth Edison Company.

${ }^{30}$ L. S. Hyman, American's Electric Utilities: Past, Present and Future, Fifth Edition (Arlington, VA: Public Utilities Reports, Inc., 1994), p. 102.

31 Ibid., p. 101.

32 The Securities and Exchange Commission actually noted 142 registered holding companies in 1939. Securities and Exchange Commission, Fifth Annual Report of the Securities and Exchange Commission, Fiscal Year Ended June 30, 1939 (Washington, DC, 1940 ), pp. 1 and 43.

${ }^{33}$ T. J. Brennan et al., A Shock to the System: Restructuring America's Electricity Industry (Resources for the Future: Washington, DC, July 1996), p. 160 .

${ }^{34}$ For a more extensive discussion of PUHCA, see Energy Information Administration, The Public Utility Holding Company Act of 1935: 1935-1992, DOE/EIA-0563 (Washington, DC, January 1993), pp. 39-53. 
The holding companies at first resisted compliance, and some challenged the constitutionality of the Act, but the Supreme Court upheld PUHCA's legality. By 1947, virtually all holding companies had undergone some type of simplification or integration, and by 1950 the utility reorganizations were virtually complete. ${ }^{35}$ As of January 1,1995 , there were only 15 registered holding companies in the Unites States (Table 2). Additionally, there were 53 holding companies exempt from SEC regulation by SEC order, and 112 holding companies exempt since they fell under the umbrella of PUHCA Section 3 (a) (1) and/or (2), which states:

The Commission ... shall exempt any holding company, and every subsidiary company thereof ... from any... provisions of this title... unless it finds the exemption detrimental to the public interest or the interest of investors or consumers if-
(1) such holding company, and every subsidiary company thereof . . . are predominantly intrastate in character and carry on their business substantially in a single State in which such holding company and every such subsidiary company thereof are organized;

(2) such holding company is predominantly a public utility company whose operations... do not extend beyond the State in which it is organized and States contiguous thereto. ${ }^{36}$

Although PUHCA reform or outright repeal is being considered today because of the move to restructure (see Chapter 6), the same plea for change has been made several times over the past 20 years. In the 1970s, utilities sought relief from PUHCA constraints in order to diversify into nonutility lines of business as a means to improve their declining profits. In the 1980 s, they sought

Table 2. Relative Size of Registered Holding Companies as of January 1, 1995

\begin{tabular}{|c|c|c|c|}
\hline & $\begin{array}{l}\text { Consolidated } \\
\text { Assets }\end{array}$ & $\begin{array}{c}\text { Twelve Months } \\
\text { Consolidated Operating } \\
\text { Revenues }\end{array}$ & Retained Earnings ${ }^{a}$ \\
\hline Holding Company System & \multicolumn{3}{|c|}{ Thousand Dollars } \\
\hline Allegheny Power System, Inc. (E) & $6,362,225$ & $2,451,684$ & 946,919 \\
\hline American Electric Power Company $(E)$ & $15,712,699$ & $5,504,670$ & $1,325,581$ \\
\hline Central and South West Corp. (E) . . . . . . & $10,909,000$ & $3,623,000$ & $1,824,000$ \\
\hline CINergy Corp. (E) & $8,149,842$ & $2,924,177$ & 877,061 \\
\hline Columbia Gas System, Inc. (G) .. & $7,164,880$ & $2,833,418$ & 430,500 \\
\hline Consolidated Natural Gas Company (G) & $5,518,673$ & $3,329,853$ & $1,469,879$ \\
\hline Eastern Utilities Associates (E) & $1,234,049$ & 564,278 & 56,617 \\
\hline Entergy Corp. (E) . . . . . . & $22,613,491$ & $5,963,290$ & $2,223,739$ \\
\hline General Public Utilities Corp. (E) & $9,209,777$ & $3,649,516$ & $1,775,759$ \\
\hline National Fuel Gas Company (G) & $2,041,618$ & $1,102,746$ & 375,013 \\
\hline New England Electric System $(E) \ldots$ & $5,084,841$ & $2,243,029$ & 779,045 \\
\hline Northeast Utilities $(E)$. & $10,584,880$ & $3,642,742$ & 946,988 \\
\hline PECO Energy Power Company (E) & 102,585 & 15,714 & 7,471 \\
\hline Southern Company $(E) \ldots \ldots$ & $27,042,887$ & $8,297,387$ & $3,191,000$ \\
\hline Unitil Corp. (E) .... & 204,521 & 153,416 & 27,183 \\
\hline Total $\ldots \ldots \ldots \ldots \ldots \ldots \ldots \ldots \ldots \ldots$ & $131,935,968$ & $46,298,920$ & $16,256,755$ \\
\hline
\end{tabular}

${ }^{2}$ Retained earnings are the balance, either debit or credit, of appropriated or unappropriated earnings of an entity that are retained in the business.

$E=$ Electric

$\mathrm{G}=$ Gas.

Source: Securities and Exchange Commission, Financial and Corporate Report (Washington, DC) (not dated).

35 J. Seligman, The Transformation of Wall Street and The History of the Securities and Exchange Commission in Modern Corporate Finance, (Boston, MA: Houghton, Mifflin Company, 1982), p. 134.

${ }^{36}$ Public Utility Holding Company Act of 1935 (Public Law 74-333), Section 3. 
to diversify in order to exploit the positive experience of independent power producers under PURPA, which eliminated PUHCA constraints on certain qualifying generating facilities. It was not until 1992 that EPACT significantly modified PUHCA by allowing both utilities and nonutilities to build, own, and operate power plants for wholesaling electricity in more than one geographic area. A more detailed discussion of the effects of PURPA and EPACT on PUHCA provisions follows.

\section{The Public Utility Regulatory Policies Act of 1978}

In October 1973, the Arab oil-producing nations imposed a ban on oil exports to the United States. Although the ban lasted only until March 1974, its effects increased public awareness of energy issues, resulted in higher energy prices, contributed to inflation, and acted as a catalyst for the proposal and adoption of the National Energy Act. This Act, which was signed into law in November 1978, comprises five different statutes: the Public Utility Regulatory Policies Act (PURPA), the Energy Tax Act, the National Energy Conservation Policy Act, the Powerplant and Industrial Fuel Use Act, and the Natural Gas Policy Act. The general purpose of the National Energy Act was to ensure sustained economic growth while also permitting the economy time to make an orderly transition from the past era of inexpensive energy resources to a period of more costly energy. ${ }^{37}$ Although it had numerous objectives, a primary goal of the National Energy Act was to reduce the Nation's dependence on foreign oil and its vulnerability to interruptions in energy supply. Another was to develop renewable and alternative energy sources.

The most significant part of the National Energy Act of 1978 with regard to the structure of the electric power industry was PURPA, specifically, Section 2 of the Act:

The Congress finds that the protection of the public health, safety, and welfare, the preservation of national security, and the proper exercise of congressional authority under the Constitution to regulate interstate commerce require-
(1) a program providing for increased conservation of electric energy, increased efficiency in the use of facilities and resources by electric utilities, and equitable retail rates for electric consumers,

(2) a program to improve the wholesale distribution of electric energy, the reliability of electric service, the procedures concerning consideration of wholesale rate applications before the Federal Energy Regulatory Commission, and to provide other measures with respect to the regulation of the wholesale sale of electric energy,

(3) a program to provide for the expeditious development of hydroelectric power... ${ }^{38}$

Section 210 of PURPA requires electric utilities to interconnect with and buy whatever amount of capacity and energy is offered from any facility meeting the criteria for a qualifying facility $(\mathrm{QF})$ (see inset). It further requires that the utility pay for that power at the utility's own incremental or avoided cost of production. ${ }^{39}$ This provision created, by fiat, a market in which QFs could unilaterally sell electricity to utilities. To further ease the burden on nonutility companies wishing to enter the electric generating market, Congress exempted most $Q F s$ from rate and accounting regulation by FERC under the Federal Power Act, from regulation by the SEC under PUHCA, and from State rate, financial, and organizational regulation of utilities. It also simplified contracts, streamlined the power sales process, increased financial certainty for creditors and equity sponsors, and generally eliminated several procedural and planning problems that had made entry into the electricity market prohibitive for most of the smaller energy producers. ${ }^{40}$

In passing PURPA, Congress ensured that QFs had a guaranteed market for their power at a price equal to the avoided cost of the utilities that purchased their power. This is quite different from traditional regulation, which generally sets the price of electricity on the basis of the cost (to the producer) of producing it. The QFs themselves are not subject to cost-of-service regulation, and the prices paid to them are not based on their cost of producing the electricity. Instead, the prices they are paid reflect the avoided cost of the purchasing utility, that is, the cost the

${ }^{37}$ J. H. Minan and W. H. Lawrence, "Federal Tax Incentives and Solar Energy Development," Energy Law Service, Monograph 7F (Wilmette, IL, September 1981), p. 5.

${ }^{38}$ Public Utility Regulatory Policies Act of 1978 (Public Law 95-617), Section 2.

39 The law required electric utilities to purchase electricity from qualified facilities at "a rate which [does not] exceed the incremental cost to the electric utility of alternative electric energy ... [which the] utility would generate or purchase from another source." Public Utility Regulatory Policies Act of 1978 (Public Law 95-617), Title II, Section 210, Paragraphs (b), (2), and (d).

${ }^{40}$ Energy Information Administration, Renewable Energy Annual 1995, DOE/EIA-0603(95) (Washington, DC, December 1995), p. xxvi. 
PURPA was designed to encourage the efficient use of fossil fuels in electric power production through cogenerators and the use of renewable resources through small power producers. Because of amendments to PURPA in 1990, the term "small power producer" is now a misnomer. The amendments eliminated the original size criterion for all energy sources except hydroelectric, while maintaining the criterion for the type of energy used. (Under PURPA provisions, both cogenerators and small power producers cannot have more than 50 percent of their equity interest held by an electric utility.)

\section{Cogenerators}

Cogenerators are generators that sequentially or simultaneously produce electric energy and another form of energy (such as heat or steam) using the same fuel source. Cogeneration technologies are classified as "topping-cycle" and "bottomingcycle" systems. In a typical topping-cycle system, hightemperature, high-pressure steam from a boiler is used to drive a turbine to generate electricity. The waste heat or steam exhausted from the turbine is then used as a source of heat for an industrial or commercial process. In a typical bottoming-cycle system, high-temperature thermal energy is produced first for applications such as reheat furnaces, glass kilns, or aluminum metal fumaces, and heat is then extracted from the hot exhaust stream of the primary application and used to drive a turbine. Bottoming-cycle systems are generally used in industrial processes that require very high-temperature heat.

For a nonutility to be classified as a cogenerator qualified under PURPA, it must meet certain ownership, operating, and efficiency criteria established by FERC. The operating requirements stipulate the proportion (applicable to oil-fired facilities) of output energy that must be thermal energy, and the efficiency requirements stipulate the maximum ratio of input energy to output energy.

\section{Renewables}

A renewable resource is an energy source that is regenerative or virtually inexhaustible. Renewable energy includes solar, wind, biomass, waste, geothermal, and water (hydroelectric). Solar thermal technology converts solar energy through high concentration and heat absorption into electricity or process energy. Wind generators produce mechanical energy directly through shaft power. Biomass energy is derived from hundreds of plant species, various agricultural and industrial residues, and processing wastes. Industrial wood and wood waste are the most prevalent form of biomass energy used by nonutilities. Geothermal technologies convert heat naturally present in the earth into heat energy and electricity. Hydroelectric power is derived by converting the potential energy of water to electrical energy using a hydraulic turbine connected to a generator.

For a nonutility to be classified as a small power producer under PURPA, it also must meet certain ownership and operating criteria established by FERC. In addition, renewable resources must provide at least 75 percent of the total energy input. PURPA provisions enabled nonutility renewable electricity production to grow significantly, and the industry responded by improving technologies, decreasing costs, and increasing efficiency and reliability. utility avoided by not producing the electricity received from the QF or purchasing it from another source. One initial interpretation of avoided cost under PURPA was the cost of additional electricity produced by the utility itself. However, under PURPA's requirements, some utilities which already had sufficient supply available to meet demand, either through their own generation or through purchases from other sources, in addition had to purchase $\mathrm{QF}$ generation.

In the mid-1980s, several States began to review their own and others' experiences with PURPA implementation. Maine, in particular, concluded that avoided costs could be established through competitive bidding among QFs, as opposed to setting them administratively. In 1984, Central Maine Power (CMP) and the Maine Public Service Commission (PSC) became the first to put competitive bidding into practice. CMP did this in an effort to protect itself from oversupply of electricity by QFs after the PSC had previously decided that avoided-cost rates for QFs were to be based on the cost of production of electricity by nuclear facilities. These high rates spurred a larger volume of offers than CMP needed. The switch to marketbased pricing provided a new avoided cost for purchased power from QFs that was below the initial avoided cost levels that would have prevailed in the absence of bidding. ${ }^{41}$

\section{The Energy Policy Act of 1992}

In 1992, President George Bush signed the Energy Policy Act (EPACT), which substantially reformed PUHCA and made it even easier for nonutility generators to enter the wholesale market for electricity by exempting them from PUHCA constraints. The law includes language that created a new category of power producers, called exempt wholesale generators (EWGs). ${ }^{42}$ By exempting them from

${ }^{41}$ W. H. Wellford and H. E. Robertson, "Bidding for Power: The Emergence of Competitive Bidding in Electric Generation," Working Paper No. 2 , National Independent Energy Producers (March 1990), p. 3.

42 An EWG is a corporate entity. An EWG-owned facility is called an "eligible facility." In this report, "EWG" refers to an EWG-owned eligible facility. 
PUHCA regulation, the law eliminated a major barrier for utility-affiliated and nonaffiliated power producers who want to compete to build new non-rate-based power plants. EWGs differ from PURPA QFs in two ways. First, they are not required to meet PURPA's cogeneration or renewable fuels limitations. Second, utilities are not required to purchase power from EWGs. Marketing of EWG power will probably be facilitated by transmission provisions that gave FERC the authority to order utilities to provide access to their transmission systems.

The law has been hailed as one of the most significant pieces of legislation in the history of the industry. In addition to giving EWGs and QFs access to distant wholesale markets, the law provides transmissiondependent utilities the ability to shop for wholesale power supplies and frees such utilities, mostly municipals and rural cooperatives, from their dependency on surrounding investor-owned utilities for wholesale power requirements. The transmission provisions have led to a nationwide open-access electric power transmission grid for wholesale transactions. (The law specifically prohibits FERC from ordering retail wheeling--the transmission of power to a final customer.) Independent power producers, publicly owned utilities, rural cooperatives, and industrial producers (i.e., anyone selling power at wholesale) gained the ability to win from FERC orders that require transmission-owning utilities to provide transmission service at FERC-defined "just and reasonable" rates.

The language of the law concerning pricing directs FERC, when it issues a transmission order, to approve rates which permit the utility to recover "all legitimate, verifiable economic costs incurred in connection with the transmission services." Such costs include "an appropriate share, if any, [of] necessary associated services, including, but not limited to, an appropriate share of any enlargement of transmission facilities." The language also says that FERC "shall ensure, to the extent practicable," that costs incurred by the wheeling utility are recovered from the transmission customer rather than "from a transmitting utility's existing wholesale, retail, and transmission customers."

Probably the most salient characteristics of EPACT's reforms to PUHCA were the expansion of FERC authority and the creation of a category of entities exempt from SEC regulation. However, the most bitter dispute over PUHCA reform was in the area of transmission access. Some nonutility groups had argued that revising PUHCA without revising transmission-access rules would reinforce the utility monopolistic structure. The main thrust of the argument against PUHCA reform with increased transmission access authority was that the high level of reliability enjoyed by the Nation would be compromised.

Although regulated public utilities had no general obligation to provide access to their transmission lines before EPACT, there are several restricted exceptions to this generalization. One is the requirement, under PURPA, that utilities interconnect with and purchase power from QFs. Another is that under the Federal Power Act, as amended by PURPA, FERC had the authority to require wheeling under limited circumstances. But, in its first deliberation on this authority, FERC found that the authority was limited so that it did not allow FERC to require a utility to wheel power to its wholesale customers or to encourage competition in bulk power markets. ${ }^{43}$ This interpretation of PURPA circumscribed the conditions under which FERC could order wheeling. The interpretation by FERC was later upheld by the courts. However, the enactment of EPACT broadened FERC's authority to order wheeling.

The Federal courts can also require wheeling, but only when the Sherman Antitrust Act has been violated. ${ }^{44}$ Violations include circumstances in which a refusal to wheel power is determined to be anticompetitive or an attempt to monopolize a particular market. Also, under the Atomic Energy Act, the Nuclear Regulatory Commission and the U.S. Attorney General may require wheeling access as a condition for issuing a construction permit for a nuclear plant. ${ }^{45}$ EPACT broadened available exceptions substantially by giving FERC new authority to order utilities to provide wheeling over their transmission systems to utilities and nonutilities. FERC implementation of this legislation is described in Chapter 7 of this report.

In addition to the preceding statutory background regarding the electric power industry, the inset below provides a synopsis of a related subject-U.S. Supreme Court cases and decisions that have had major impacts on the industry.

${ }^{43}$ Southeastern Power Administration v. Kentucky Utilities Company, 25 FERC $\$ 61,204$ (1983).

${ }^{44}$ Otter Tail Power Company v. Federal Power Commission, 410 U.S. 366 (1973).

${ }^{45}$ Alabama Power Company v. Nuclear Regulatory Commission, 692 F.2d 1362 (11th Cir. 1982). 


\section{Major U.S. Supreme Court Cases Affecting the Electric Power Industry}

\begin{tabular}{|c|c|c|}
\hline Court Case & Date & Decision \\
\hline $\begin{array}{l}\text { Munn v. Illinois } \\
\text { (94 U.S. 113) }\end{array}$ & 1877 & $\begin{array}{l}\text { The Supreme Court establishes the rights of government to regulate } \\
\text { and set rates for companies that provide vital public services in a } \\
\text { monopolistic business environment. }\end{array}$ \\
\hline $\begin{array}{l}\text { Smith v. Ames } \\
\text { (169 U.S. 466) }\end{array}$ & 1898 & $\begin{array}{l}\text { The Supreme Court decrees just compensation on fair value. The } \\
\text { decision in this case upheld the right of the State to regulate the prices } \\
\text { charged to the public by a business "affected with a public interest." }\end{array}$ \\
\hline $\begin{array}{l}\text { Rhode Island PUC v. Attleboro } \\
\text { (273 U.S. 83) }\end{array}$ & 1927 & $\begin{array}{l}\text { The Supreme Court declares that selling electricity interstate cannot be } \\
\text { regulated by a State. }\end{array}$ \\
\hline $\begin{array}{l}\text { Ashwander v. TVA } \\
\text { (297 U.S. 288) }\end{array}$ & 1936 & $\begin{array}{l}\text { The Supreme Court upholds the constitutionality of the Tennessee } \\
\text { Valley Authority. }\end{array}$ \\
\hline $\begin{array}{l}\text { Electric Bond \& Share v. SEC } \\
\text { (303 U.S. 419) }\end{array}$ & 1938 & The Supreme Court upholds the Holding Company Act of 1935. \\
\hline $\begin{array}{l}\text { Tennessee Electric Power Co. v. } \\
\text { Tennessee Valley Authority } \\
\text { (306 U.S. 118) }\end{array}$ & 1939 & $\begin{array}{l}\text { The Supreme Court rules in TVA's favor, despite the claims that TVA } \\
\text { threatened the large investments already made by privately owned } \\
\text { utilities. This ruling resulted in TVA becoming a major electricity } \\
\text { supplier in the region. }\end{array}$ \\
\hline $\begin{array}{l}\text { F.P.C. v. Hope Natural Gas } \\
(320 \text { U.S. 591) }\end{array}$ & 1944 & $\begin{array}{l}\text { The Supreme Court closes a longstanding dispute by allowing either } \\
\text { original or replacement cost accounting in utility rate making, so long } \\
\text { as just and reasonable rates result. }\end{array}$ \\
\hline $\begin{array}{l}\text { Otter Tail Power Co. v. United States } \\
(410 \text { U.S. } 366)\end{array}$ & 1973 & $\begin{array}{l}\text { The Supreme Court finds Otter Tail Power Co. in violation of Section } 2 \\
\text { of the Sherman Act, for refusing to sell or wheel wholesale power to } \\
\text { proposed municipal systems. }\end{array}$ \\
\hline $\begin{array}{l}\text { FPC v. Conway Corp. } \\
\text { ( } 426 \text { U.S. } 271 \text { ) }\end{array}$ & 1976 & $\begin{array}{l}\text { The Supreme Court states that FERC, in setting wholesale rates, must } \\
\text { act consistently with the policies of the Federal antitrust laws. }\end{array}$ \\
\hline $\begin{array}{l}\text { Burke v. Narragansett Electric Co. } \\
\text { (435 U.S. 972) }\end{array}$ & 1978 & The Supreme Court affirms primacy of FERC rate setting. \\
\hline $\begin{array}{l}\text { FERC v. Mississippi } \\
\text { (456 U.S. } 742)\end{array}$ & 1982 & The Supreme Court upholds the constitutionality of PURPA. \\
\hline $\begin{array}{l}\text { American Paper Institute v. American } \\
\text { Electric Power Service Corp. } \\
\text { (461 U.S. 402) }\end{array}$ & 1983 & $\begin{array}{l}\text { The Supreme Court upholds the constitutionality of FERC's } \\
\text { cogeneration rules promoted pursuant to PURPA. }\end{array}$ \\
\hline $\begin{array}{l}\text { Nantahala Power \& Light Co. v. Thornburg } \\
\text { (476 U.S. 953) }\end{array}$ & 1986 & $\begin{array}{l}\text { Among other outcomes, the Supreme Court confirms that FERC has } \\
\text { exclusive authority over wholesale electric rates. }\end{array}$ \\
\hline $\begin{array}{l}\text { Mississippi Power \& Light Co. v. } \\
\text { Mississippi } \\
\text { (487 U.S. } 354)\end{array}$ & 1988 & $\begin{array}{l}\text { The Supreme Court determines that FERC authority is controlling and } \\
\text { that a State commission is obligated to honor a FERC order. The } \\
\text { Court stated "FERC-mandated allocations of power are binding on } \\
\text { States, and States must treat those allocations as fair and reasonable } \\
\text { when determining retail rates." }\end{array}$ \\
\hline
\end{tabular}




\section{Major U.S. Supreme Court Cases Affecting the Electric Power Industry (Continued)}

\begin{tabular}{|c|c|c|}
\hline Cour & ate & eci \\
\hline $\begin{array}{l}\text { Duquesne Light Co. } \\
\text { (48 U.S. 299) }\end{array}$ & 1989 & $\begin{array}{l}\text { "U.S. Supreme Court held that absent any showing that a State's rate } \\
\text { making methodology results in unreasonable rates that throw into } \\
\text { jeopardy the financial integrity of the utilities or otherwise fail to } \\
\text { compensate shareholders for their risks of investment, no } \\
\text { impermissible taking exists. Further, the Constitution of the United } \\
\text { States does not mandate any particular rate-making methodology for } \\
\text { State regulatory commissions." }\end{array}$ \\
\hline \multicolumn{3}{|c|}{$\begin{array}{l}{ }^{a} \text { This inset highlights the major U.S. Supreme Court cases that affect the electric power industry, stating the final decision of } \\
\text { the Court without discussing in detail the contents of the case. } \\
\text { 'This case, Mississippi Power \& Light Co. v. Mississippi, continues the holding found by the U.S. Supreme Court in the } \\
\text { Nantahala Power \& Light Co. V. Thornburg case. } \\
\text { CW. F. Fox, Jr., Regulatory Manual Series: Federal Regulation of Energy (Shepard's/McGraw-Hill, Inc., 1993), p. } 149 \text {. } \\
\text { 'This case is a final construction work in progress (CWIP) case. FERC issued a CWIP rule effective July } 1,1983 \text { (see } 48 \\
\text { Fed. Reg. } 24323 \text { (June 1, 1983)). This means that a utility may include, in its rate base, up to } 50 \text { percent of its CWIP costs for } \\
\text { ongoing construction projects and for the costs of nuclear fuel in the process of fuel refinement, conversion, enrichment, and } \\
\text { fabrication. In addition, the rule continues to permit utilities to include all CWIP costs associated with pollution control and fuel } \\
\text { conversion facilities. See W. F. Fox, Jr., Regulatory Manual Series: Federal Regulation of Energy (Shepard's/McGraw-Hill, Inc. } \\
\text { 1993), p. 150. } \\
\text { 'W. F. Fox, Jr., Regulatory Manual Series: Federal Regulation of Energy (Shepard's/McGraw-Hill, Inc., 1993), p. 153. } \\
\text { FERC = Federal Energy Regulatory Commission. } \\
\text { TVA = Tennessee Valley Authority. } \\
\text { PG\&E = Pacific Gas \& Electric Company. } \\
\text { PURPA = Public Utility Regulatory Policies Act. } \\
\text { PUC = Public Utility Commission. } \\
\text { Source: Based on information compiled by the Office of Coal, Nuclear, Electric and Alternate Fuels from various documents } \\
\text { from the Department of Energy Library. For more information, refer to D. J. Muchow and W. A. Mogel, Energy Law and } \\
\text { Transactions (Matthew Bender, April 1996); and W. F. Fox, Jr., Regulatory Manual Series: Federal Regulation of Energy } \\
\text { (Shepard's/McGraw-Hill, Inc., 1993). }\end{array}$} \\
\hline
\end{tabular}





\section{Part II:}

The U.S. Electric Power Industry

in Transition to Competition 


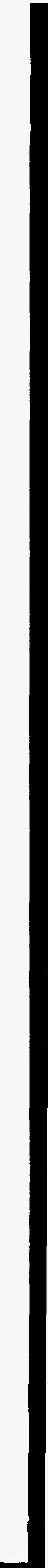




\section{Factors Underlying the Restructuring of the Electric Power Industry}

In recent years, economists and other public policy analysts have stressed the advantages of competition over regulated monopolies and have promoted the idea that free markets can drive down costs and prices by reducing inefficiencies. Competitive industries also may be more likely to spur innovations with new technologies.

Recent actions with regard to electric power by legislators and regulators in the United States are evidence of the changing approach to dealing with an existing regulated monopoly. Originally, protecting consumers was a primary motivation for decisions to impose regulatory constraints on the industry. Today, legislators and regulators are instituting laws and rules that promote competition for the same purpose, because they believe that consumers will benefit more from an industry whose members must compete for customers than from an industry composed of regulated monopolies.

Examples of this changed climate occur at the State and Federal levels as well as in other countries of the world. In the United States, the Energy Policy Act of 1992 was enacted by the Federal Government to promote competition in electricity generation. Regulators in the State of New Hampshire have required price roll-backs for electricity, and many other States are in the process of instituting retail competition in their respective jurisdictions. Many individuals and groups in California have asked regulators and legislators to allow new companies to generate and sell electricity. This changed climate is one of the factors underlying restructuring.

For most of the industry's history, consumers welcomed the protection that regulation afforded them and felt that this means of oversight assured them that the prices they were paying were fair. Now, however, the consumers themselves are pushing for competition and regulatory reform. The main thrust is coming from large industrial users of electricity who, in some areas of the United States, have been burdened by high electricity prices while their competitors in other areas pay far less for a kilowatthour of electricity. These price differentials are another factor underlying the restructuring of the industry.

A third factor that has had a significant impact on restructuring is technological advances in the production of electricity. This factor has allowed nonutilities, using recently advanced, aero-derivative gas turbine technologies, to generate electricity more cheaply than the total (regulatory) costs of many utilities that now use previously developed fossil-fueled or nuclear-fueled steam-electric technologies. ${ }^{46}$ Also, the advanced generators are cleaner and use less fuel. Nonutilities are able to put advanced generators into operation quickly, sometimes as an alternative to utility capacity that is already built.

The following sections analyze the more quantifiable factors that are motivating the structural changes in the electric power industry-price differences and technological advances. The analyses include EIA data to quantify these factors where they are relevant.

\section{Price Differences}

While restructuring originated in fact with PURPA, large differences in the retail prices of electricity have continued to motivate some to advocate expanded restructuring. ${ }^{47}$ The current structure of the electric power industry does not provide retail customers of utilities, in general, with the opportunity to purchase electricity from sources that may have lower prices than their current suppliers. Restructuring the industry holds the possibility of allowing more choice for consumers. Many industrial customers of utilities, because they are large consumers of electricity and have a lot to gain if they can reduce their average price of electricity by choosing another provider, are especially prone to advocate further restructuring.

\footnotetext{
${ }^{46}$ H.R. Linden, "The Revolution Continues," The Electricity Joumal, Dec. 1995, pp. 55-56.

${ }^{47}$ EPACT has ameliorated these differentials at the wholesale level by allowing some wholesale customers access to lower cost power.
} 
Figure 11. Average Revenue from Electricity Sales to All Retail Consumers by State, 1995 (Cents per Kilowatthour)

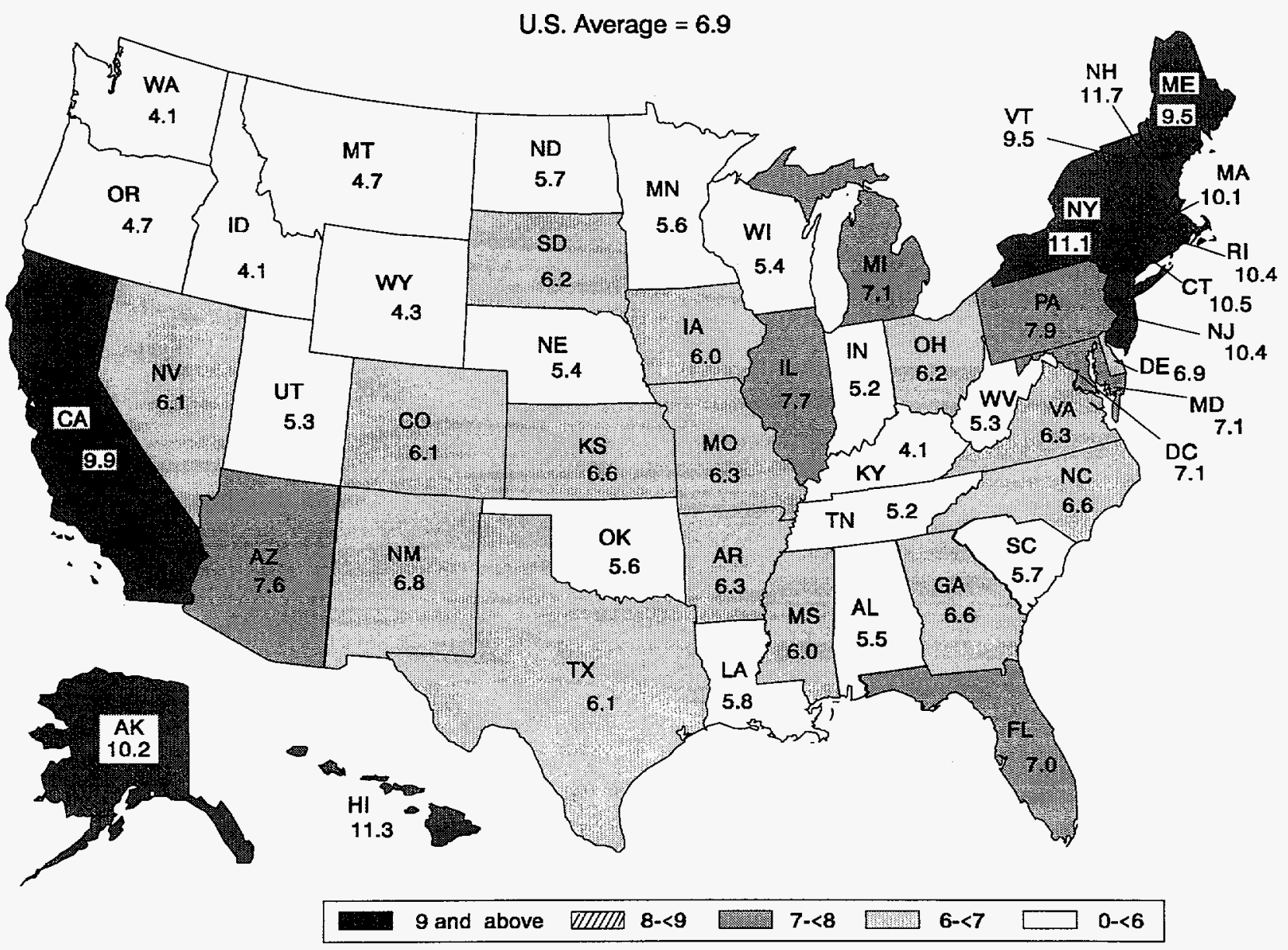

Source: Energy Information Administration, Form EIA-861, "Annual Electric Utility Report,” (1995).

They argue that price differentials among utilities provide an advantage to the competitor who is situated in an area with lower electricity prices, and that all consumers should have access to cheaper electricity. Some industrial consumers, who have threatened to purchase power from lower-priced providers, move the location of their companies, or generate their own electricity, often have "succeeded in wringing lower prices from their traditional electric utilities."

In the United States, the average revenue received per unit of electricity sold to all retail consumers varies substantially by State (Figure 11). In 1995, the States with average revenues of 9 cents per kilowatthour and above included California, the Northeast (including all the New England States), and States outside the contiguous United States. It is probably not coincidental that many of the States that are leaders in the restructuring of retail electricity markets are among the States with high average revenues. In contrast, States with average revenues below 6 cents per kilowatthour were scattered throughout the rest of the country. Most had average revenues from all consumers that were less than one-half those in States with the highest average revenue. A similar geographic pattern exists for average electricity revenues received from industrial consumers, although industrial consumers yield one-third lower average revenues than all retail customers (Figure 12). ${ }^{49}$

${ }^{48}$ T. R. Kuhn, et al., "Electric Utility Deregulation Sparks Controversy," Harvard Business Review (May/June 1996), p. 150.

${ }^{49}$ Because industrial consumers usually consume larger amounts of electricity than other consumers, and because they usually take it at higher voltages, the cost of providing each unit of electricity to them is lower. 
Figure 12. Average Revenue from Electricity Sales to Industrial Consumers by State, 1995

(Cents per Kilowatthour)

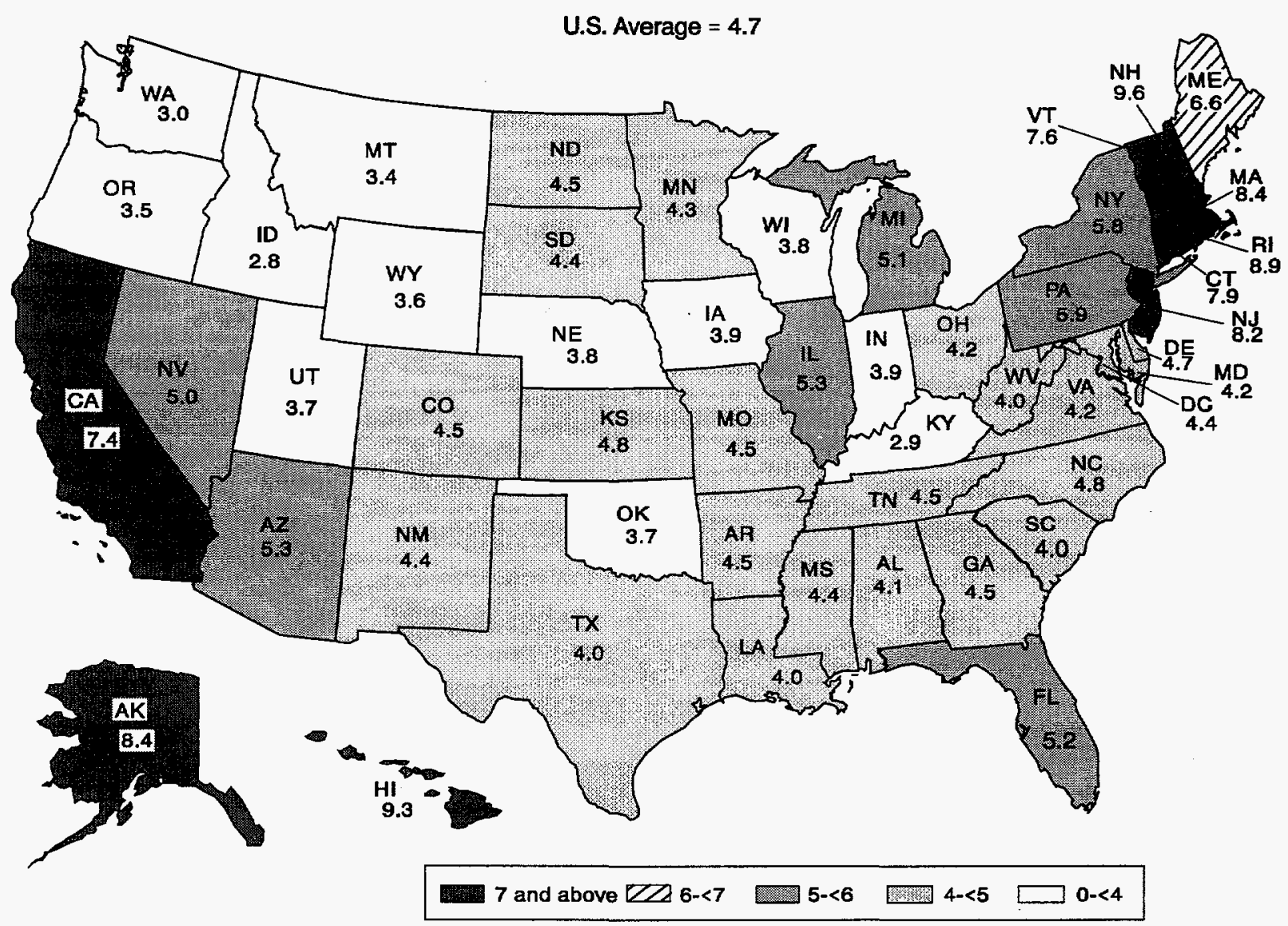

Source: Energy Information Administration, Form ElA-861, "Annual Electric Utility Report," (1995).

Large industrial consumers have played a substantial role in motivating the restructuring of the electric power industry. Their bargaining power as consumers is reflected in the declining trend of industrial prices relative to those for all consumers. While industrial consumers have paid a lower average price for electricity than other consumers for many years, the ratio of industrial revenues relative to prices for all consumers has shown two opposing trends. The price that industrial consumers paid for electricity relative to the price that all consumers paid rose from the mid-1960s until 1983; since then, it has declined (Figure 13). Because real average revenues from both groups have been falling since 1983, the relatively lower revenues for industrial consumers indicate that their average price has been falling faster than the average price charged to all consumers.

Over the years, utilities have developed programs to help lower the price of electricity to the industrial sector. They traditionally have relied on alternative rate design approaches, such as interruptible service and time-of-use rates, to reduce the time-variation of demand by the industrial sector. The programs also use technological approaches, such as thermal storage. A number of utilities have developed flexible custom measure programs, which allow industrial energy users and utilities to work together to identify cost-effective programs. ${ }^{50}$

\footnotetext{
${ }^{50}$ Energy Information Administration, Electric Power Annual 1992, DOE/EIA-0348(92) (Washington, DC, January 1994), p. 104.
} 
Figure 13. Relative Average Revenue of Electricity Sales: Ratio of Industrial Consumers to All Consumers, 1960-1995

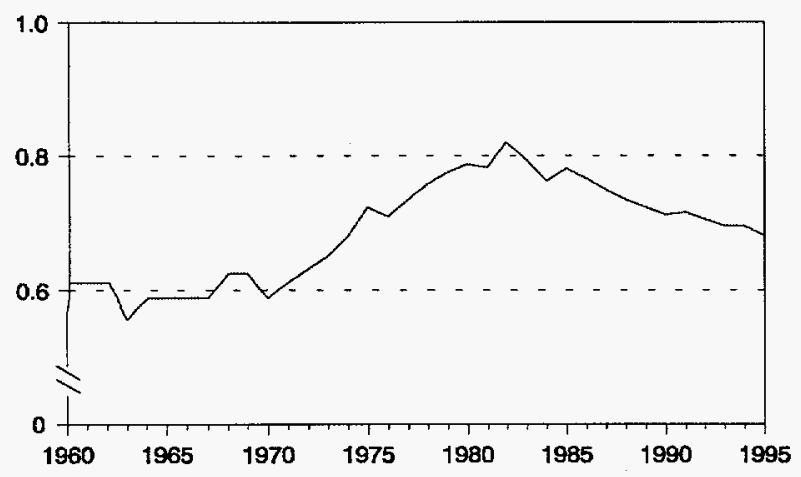

Source: Energy Information Administration, Annual Energy Review 1995, DOE/EIA-0384(95) (Washington, DC, July 1996), Table 8.11 .

\section{Technological Advances}

The restructuring of the electric power industry has been sustained by technological improvements in gas turbines. "In areas with cheap...natural gas-most notably the United States-gas turbines [are] the least cost option [for new electricity generating capacity]. ${ }^{\prime \prime 1}$ These improvements also have recast economies of scale in electric power generation technologies. No longer is it necessary to build a 1,000 megawatt generating plant to exploit economies of scale. Combined-cycle gas turbines reach maximum efficiency at 400 megawatts, while aero-derivative gas turbines can be efficient at scales as small as 10 megawatts. ${ }^{52}$

In its modeling of the electric power industry, EIA compares the estimates of the costs of different generating technologies. In its forecasts, "[t]echnology types for new electric generating capability are chosen on the basis of cost while meeting local and Federal emissions constraints. " ${ }^{153}$ The reference case forecast recently released by EIA projects that, of the 302 gigawatts of new
Table 3. Total Projected Additions of Electricity Generating Capability for Electric Generators by Technology Type, 1995-2015

(Gigawatts)

\begin{tabular}{cc}
\multicolumn{2}{c}{ (Gigawatts) } \\
\hline Technology & Capability Additions \\
\hline Coal Steam $\ldots \ldots \ldots \ldots \ldots \ldots$ & 35.5 \\
Combined Cycle $\ldots \ldots \ldots \ldots \ldots$ & 138.1 \\
Combustion Turbine/Diesel $\ldots$. & 114.5 \\
Nuclear Power $\ldots \ldots \ldots \ldots \ldots$ & 1.2 \\
Fuel Cells $\ldots \ldots \ldots \ldots \ldots \ldots$ & 2.1 \\
Renewable Sources $\ldots \ldots \ldots \ldots$ & 10.6 \\
Total ................... & 302.0 \\
\hline
\end{tabular}

Source: Energy Information Administration, AEO97 National Energy Modeling System run AEO97B.D100296K.

generating capability projected to be added by electric generators between 1995 and 2015, more than 80 percent will be either combined-cycle or combustion turbine technology (Table 3$)^{54}$

The operating and maintenance costs for fossil-fueled steam-electric and nuclear steam-electric generation at major investor-owned electric utilities averaged about 2.2 cents per kilowatthour in 1994,55 but some of these utilities reported operating and maintenance costs in excess of 3 cents per kilowatthour in $1994 .^{56}$ Total costs, including operating and maintenance plus capital costs, average 3 cents per kilowatthour for the new combined-cycle gas turbine technologies. ${ }^{57}$ Based on these data, combinedcycle gas turbines apparently can be built and operated more cheaply than some existing utility steam-electric generation. Therefore, in many cases, it is less expensive for nonutilities (or utilities) to build new capacity than to operate some of the more expensive capacity that is already in existence.

The following chapter outlines the major issues that are framing the current debate over Federal initiatives to facilitate the industry's transition to a competitive market environment.

${ }^{51}$ H.R. Linden, "The Revolution Continues," The Electricity Journal (December 1995), p. 54.

${ }^{52}$ R.E. Balzhiser, "Technology-It's Only Begun to Make a Difference," The Electricity Journal (May 1996).

${ }^{53}$ Energy Information Administration, Annual Energy Outlook 1996, DOE/EIA-0383(96) (Washington, DC, January 1996), p. 32.

${ }^{54}$ Energy Information Administration, AEO97 National Energy Modeling System run AEO97B.D100296K.

${ }^{55}$ Energy Information Administration, Financial Statistics of Major U.S. Investor-Owned Electric Utilities 1994, DOE/EIA-0437(94)/1 (Washington, DC, December 1995), Table 14.

${ }^{56} \mathrm{Ibid}$., Tables 41 and 43.

${ }^{57}$ H.R. Linden, "The Revolution Continues," The Electricity Journal (December 1995), p. 55. 


\section{Federal Legislative Initiatives for Change: The Issues}

Some groups contend that two particular statutes are irrelevant in an era of competition, and that these statutes are actually hindering the industry's transition from a regulated monopoly. They are the Public Utility Holding Company Act of 1935 (PUHCA) and the Public Utility Regulatory Policies Act of 1978 (PURPA). This chapter addresses the current debate over the repeal of these laws ${ }^{58}$ and examines miscellaneous proposals that were introduced during the 104th Congress ${ }^{59}$ to deal with restructuring. The discussion focuses on several bills that were introduced for the purpose of providing a comprehensive and Federally guided national approach to competition in the electric power industry.

\section{The Current Debate Over PUHCA}

Although a vigorous debate is now taking place as to whether PUHCA's provisions are relevant today, there seems to be little question among the debaters that six decades ago PUHCA was the right law at the right time. PUHCA achieved what it was designed to do-it broke up the large and powerful trusts that abused their powers over the Nation's electric and gas distribution networks. However, in today's environment of increasing electric industry competition, there are those who believe that PUHCA's regulations are antiquated and are now impeding the transition to competition. Conversely, others feel strongly that, until the industry completes the transition, PUHCA's regulations must stay in effect in order to protect consumers. Arguments for and against the repeal of PUHCA are summarized in the inset below.

Over the years, the petition for PUHCA repeal has, for the most part, been based on two arguments-that PUHCA has already achieved its goal of restructuring in order to make holding companies manageable and regulated, and that it has been rendered obsolete because of changes that have occurred in the latter part of this century which preclude the holding company abuses of yesterday. ${ }^{60}$ They are specifically:

- The development of an extensive disclosure system for all publicly held companies

- The increased competence and independence of accounting firms

- The development of accounting principles and auditing standards and the means to enforce them

- The increased sophistication and integrity of security markets and security professionals

- The increased power and ability of State regulators. ${ }^{61}$

In the mid-1980s, the Securities and Exchange Commission (SEC) determined that PUHCA had achieved its purpose and recommended repeal, but no action was taken in Congress. In 1994, the SEC again initiated a study in order to develop a staff recommendation to either repeal or reform PUHCA or to leave the law intact. In July 1994, the SEC conducted a round table discussion concerning whether or not the fundamental premise of the law and its provisions for addressing problems associated with monopolies and anticompetitive behavior were still relevant in the current increasingly competitive marketplace. In an attempt to obtain a broad cross-section of views on the subject, Federal, State, and local regulators and high-level representatives from utilities, consumer groups, trade associations, investments banks, etc., were invited to participate in the discussion. Later in the year, the SEC published a notice in the Federal Register requesting comments on the subject.

\footnotetext{
58 The following discussion regarding the pros and cons of both PUHCA and PURPA repeal reflect the views of numerous groups associated with the electric power industry. The discussion does not purport to represent the views of the Department of Energy or the Administration.

${ }^{59}$ Each Congress lasts for 2 years, commencing in January of the year following the biennial election of Members, and is divided into two sessions. If a bill is not enacted into law by the end of a certain Congress, it must be reintroduced into the next Congress for consideration.

${ }^{60}$ For a discussion of these abuses, refer to Chapter 4.

${ }^{61}$ For further discussion of these changes, see Energy Information Administration, The Public Utility Holding Company Act of 1935: 1935-1992, DOE/EIA-0563 (Washington, DC, January 1993), p. 23.
} 


\section{The Pros and Cons of PUHCA Repeal}

\begin{tabular}{|c|c|}
\hline Against Repeal & For Repeal \\
\hline $\begin{array}{l}\text { PUHCA regulations can protect consumers until } \\
\text { full retail competition is up and running. } \\
\text { - Ratepayers are still at the mercy of the regulated } \\
\text { monopolies. } \\
\text { - PUHCA guards against monopolies and } \\
\text { anticompetitive behavior. } \\
\text { - Utility monopolies are now taking actions (e.g., } \\
\text { mergers) to increase market dominance, and } \\
\text { PUHCA can keep them in control. } \\
\text { - Immediate repeal is a piecemeal approach; repeal } \\
\text { should be contained in comprehensive industry } \\
\text { restructuring legislation. } \\
\text { - PUHCA guards against interaffiliate transaction } \\
\text { abuse. }\end{array}$ & $\begin{array}{l}\text { - PUHCA's provisions are antiquated. } \\
\text { - } \text { PUHCA is impeding the transition to competition. } \\
\text { improve profits. } \\
\text { - PUHCA has already achieved its goal by making } \\
\text { holding companies manageable and regulated. } \\
\text { - The Securities and Exchange Commission itself } \\
\text { recommends a conditional repeal. } \\
\text { - PUHCA prevents all companies from playing on a } \\
\text { level field. } \\
\text { - Various other regulations have since been } \\
\text { instituted that prevent holding company abuse. } \\
\text { - Immediate repeal is necessary; it will take too long } \\
\text { if it is contained in comprehensive industry } \\
\text { restructuring legislation. }\end{array}$ \\
\hline
\end{tabular}

Based on the comments received, the earlier round table discussion, and consultations with the National Association of Regulatory Utility Commissioners (NARUC), the SEC's Division of Investment Management released a report listing three legislative options to give utility holding companies more flexibility. The Division recommended an option that dealt with conditional PUHCA repeal in a minimum 1-year transition period. The conditions included access by State regulators to the books and records of companies within a holding company system, FERC authority to exercise oversight of affiliate transactions, and, generally, that energy consumers would not lose the protection of the Federal Government.

Two bills (which are not considered comprehensive restructuring legislation) were introduced in the 104th Congress that would repeal PUHCA:

- S. 1317, Public Utility Holding Company Act of 1995, introduced on October 12, 1995, by Senator
Alphonse D'Amato (R-NY) "is intended to eliminate unnecessary regulation, yet still provide for consumer protection by providing for State commission access to books and records of all companies in a holding company system, and for Federal audit authority and oversight of affiliate transactions, to the extent that such activities affect rates, while, at the same time, affording companies the flexibility required to compete in today's energy markets." ${ }^{\prime 2}$

- H.R. 3601, Public Utility Holding Company Act of 1996, introduced on June 6, 1996, by Congressman $W$. J. Tauzin (R-LA) would repeal the 1935 Act and would amend the Federal Power Act to repeal its conflict of jurisdiction guidelines.

The bills' supporters believe that speedy passage is of utmost importance, given the rapidly changing makeup of the electric industry. They contend that the original PUHCA prevents all companies from competing on a

${ }^{62}$ S.1317, "Public Utility Holding Company Act of 1995," 104th Congress, 1st Session (October 12, 1995), p. 2. 
level playing field, which some believe is a necessity in a competitive market. Under the current law, the SEC imposes the business and financial restrictions which companies feel are unfair in the current changing environment. The major restrictions include: prices for wholesale and retail transactions are set by FERC and State utility commissions, respectively; registered holding companies need SEC approval to own electric and gas operations; mergers and acquisitions require regulatory approval; and the types of businesses in which registered holding companies may engage are severely limited, but EWGs do not have the same limitations. While other comprehensive energy legislation that has been introduced contains provisions to repeal PUHCA along with provisions aimed at addressing other restructuring issues, certain interests feel that such comprehensive proposals will take far too long to move through the system. They argue that repeal of PUHCA must be promulgated now.

Those who are against outright repeal of PUHCA are not arguing that the Act should remain in effect in an open market atmosphere. Rather, they believe that the time is not yet quite right for its repeal. Until the Nation has completed the transition to a fully competitive market, the safeguards that PUHCA provides are necessary. They question the wisdom of removing vital consumer protection mechanisms and leaving the door open to anticompetitive practices by monopolies who are at present aggressively taking actions, such as merging and diversifying, perhaps to increase their market dominance. According to John Anderson, Executive Director of the Electricity Consumers Resource Council (ELCON), "A repeal of PUHCA while the retail franchises remain in place would further expose hostage ratepayers to the risks of interaffiliate abuse and ill-advised utility forays into unrelated businesses." ${ }^{\prime 63}$

Most opponents of the legislative proposals to repeal PUHCA stress that what they are against is immediate, standalone action. Instead, they want to see well-thoughtout, comprehensive restructuring and deregulation legislation that will deal with all industry issues, including retail wheeling, stranded investment, PURPA, and FERC jurisdiction, as well as with repeal of PUHCA. Still other groups believe that even after a fully competitive market is established, PUHCA-type regulation will continue to be necessary in order to ensure that the market remains competitive.

\section{The Current Debate Over PURPA}

PURPA was born of the energy crises of the 1970s, which resulted in an intense desire by Congress to reduce the Nation's dependence on foreign oil (and fossil fuels in general) and to diversify the technologies used for electricity generation. PURPA's goal was to cultivate conservation and the efficient use of resources. ${ }^{64}$ It was successful in that it promoted cogeneration, the use of renewable resources, and other energy-efficient technologies, and it was fortuitous in that it also introduced competition by demonstrating that the generation of electricity is not a natural monopoly. But, like PUHCA, PURPA is now being targeted for repeal due to the industry's move to competition. There are many arguments on both sides of the debate over the prudence of eliminating PURPA immediately, eventually, or not at all. Those arguments are summarized in the inset below.

Legislation (which is not considered comprehensive restructuring legislation) was introduced into both Houses during the 104th Congress to address Section 210 of PURPA, which requires electric utilities to buy power from qualifying cogeneration and small power production facilities. They are specifically:

- S. 708, Electric Utility Rate Payer Act, introduced by Senator Don Nickles (R-OK) on April 6, 1995, which would repeal Section 210 while stipulating that contracts in place before October 31, 1995, would still be in effect, but that no electric utility would be obliged to enter into any new contracts after that date.

- H.R. 2562, Ratepayer Protection Act, introduced by Congressman Cliff Stearns (R-FL) on October 31, 1995, which would suspend Section 210 for any utility meeting specific eligibility criteria for a "certification of competition" from its State public utility commission.

Proponents of PURPA reform or repeal contend that the Act's mandatory purchase obligation is grossly anticompetitive and anticonsumer - anticompetitive because the Government created an artificial market by mandating that utilities buy from $\mathrm{QFs}$, and anticonsumer because numerous studies have estimated that the Act caused utilities (and ultimately, consumers) to pay billions of dollars over present market prices for power. They claim that

\footnotetext{
${ }^{63}$ J. Anderson, "Commentary: Pro \& Con," Public Utilities Fortnightly (July 15, 1995), p. 38.

${ }^{64}$ For a discussion of the events that led to PURPA and how it affected the industry, refer to Chapter 4.
} 


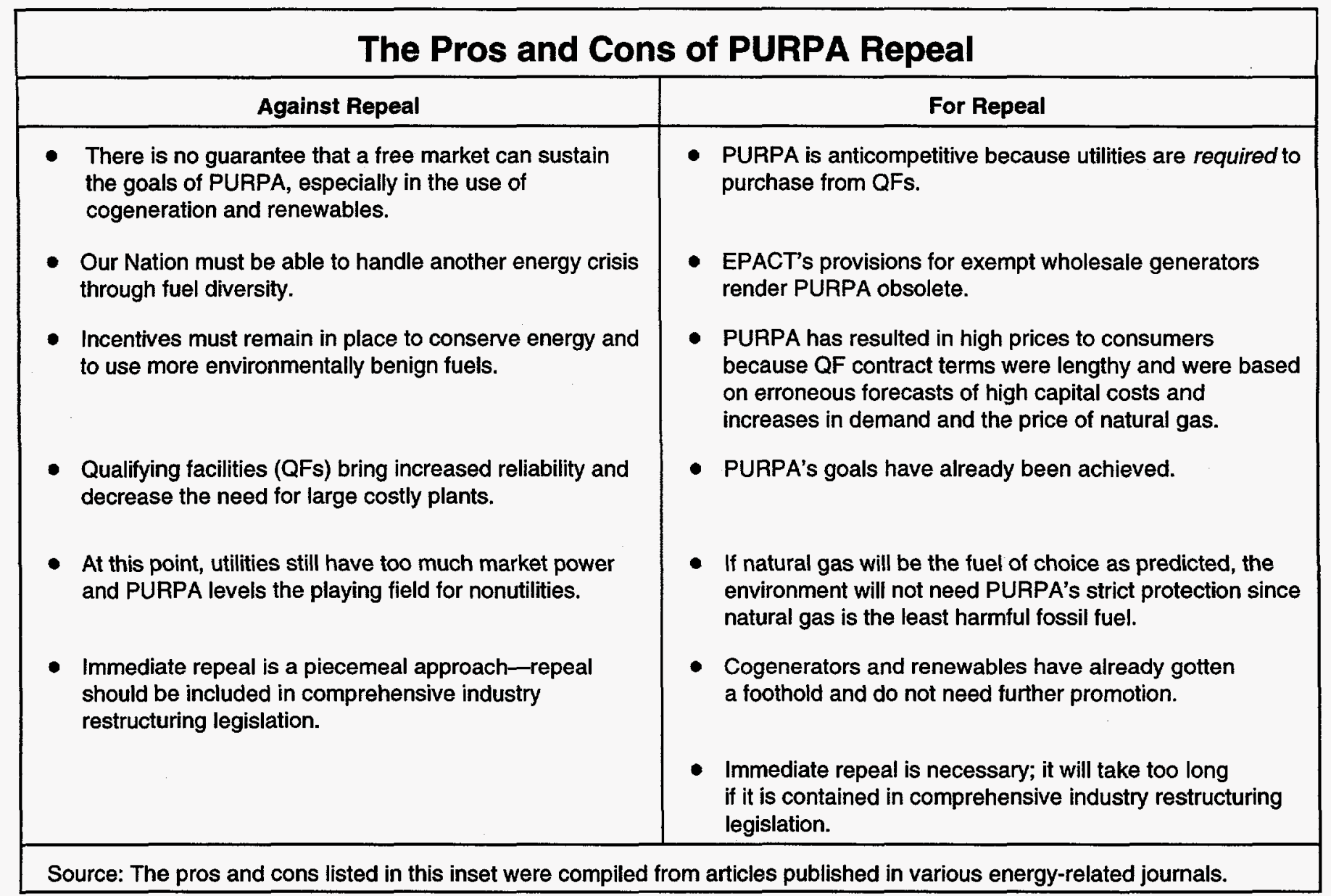

claim that, although the Act introduced competition, it can hardly be said that it did so in an atmosphere of free market participation, a basic tenet of economic theorists who stress that the rules and prices must be established by the market-not by the Government. In addition they assert that, because of EPACT's creation of exempt wholesale generators and its incorporation of competitive policies, PURPA's QF concept has been overtaken by events; i.e., the industry now realizes that nonutilities can, on the whole, cleanly and efficiently provide additional generating capacity.

Those who want PURPA eliminated now say that its mandatory purchase clause is anticompetitive and therefore is impeding the transition to competition. Furthermore, QFs have been receiving long-run avoidedcost rates that today substantially exceed current market prices. These rates were based on erroneous forecasts of sharply rising oil and natural gas prices as well as the expectation of future increases in the demand for electricity and construction of new generating capacity. From the perspective of the QFs, rates above current avoided cost ( 6 cents per kilowatthour or higher) and long-term commitments (often 10 years) were essential to establish the QF power market. By the late 1980s and early 1990s, however, oil prices had stabilized, natural gas prices had declined, and excess generating capacity in most regions of the country allowed utilities to buy capacity and energy at much lower prices than had been forecast a decade earlier. The utilities' actual avoided costs dropped lower than in the mid-1980s and were considerably lower than the levels required by the longterm contracts imposed by some State commissions. Many utilities contend that PURPA has caused dramatic hikes in retail electric rates, and many groups along with these utilities now believe that new regulatory action must be taken to correct past misjudgments. ${ }^{65}$

Forecasters have predicted that future power generation will be dominated by natural gas. Reformers argue that,

${ }^{65}$ Energy Information Administration, Renewable Energy Annual 1995, DOE/EIA-0603(95) (Washington, DC, December 1995), pp. xxvi-xxvii. 
based on these forecasts, PURPA becomes irrelevant because natural gas is inexpensive and the most environmentally benign of all the fossil fuels used in electric power generation. As mentioned earlier, some groups contend that PURPA is no longer necessary because its goals have already been achieved-i.e., cogeneration using improved turbine techniques and the use of renewable resources has not only gotten a foothold but has claimed a rather significant share of electric power production. Proponents of repeal further contend that PURPA's environmental and fuel diversification goals will be maintained by the workings of a free market.

Others are not so sure. While they may agree that a free market can provide a solution to many of the industry's problems, they seriously question the wisdom of relying on competition to continue the strides made in the use of renewables and cogeneration techniques. Currently, 79 percent of 1995 nonutility capacity and 57 percent of planned additions from 1996 through 1999 are PURPA QF facilities. Energy conservation and diversification of generating fuels were mandated by Congress because of our dependence on foreign oil and the Nation's feeling of helplessness as a result of the energy crises of the 1970s. Those fears have faded with the passage of time, but it is argued that it is not out of the realm of possibility that another crisis could occur. Indeed, some believe that it would be shortsighted and irresponsible to regard energy shortages as merely nightmares of the past and to gamble on the unlikelihood of a similar recurrence. They argue that the Nation cannot be without the ability to cope with such a situation in the future.

Even if dependence on foreign energy sources was not an issue, PURPA supporters fervently stress that common sense dictates that energy be conserved and that electricity generation use more environmentally benign fuels in order to sustain a certain quality of life for future generations ${ }^{66}$ In addition, some believe that $\mathrm{QF}$ policy corrects a market failure-i.e., the price of fossil or nuclear energy is too low based on the costly damage it does to the environment and the fact that those who create the pollution do not pay for it. In this context, conservation, diversification of fuels, and the use of renewable resources that are not depletable and other fuels that lessen the problems of acid rain and greenhouse gases must continue to be supported. (For example, in the past, California encouraged the development of renewable generating technologies through PURPA by having two-tiered avoided cost for QFs-one for fossil-fueled plants and another for renewable technologies.) To some groups, just as there is no guarantee that competition can further the goals of PURPA, there is also no question that incentives must remain in place to do so. One incentive already in use is "green" pricing - an alternative to electric utility funding of renewable energy projects (see inset below).

In addition to PURPA's merits regarding the environment and fuel diversification, its supporters point out that $Q F s$ bring increased reliability while decreasing the need for large, costly plants. In addition, they contend that today's utilities have too much market power, which makes it necessary for PURPA to continue to give nonutilities a competitive advantage, and until every electricity generator is playing on a level field, PURPA's $\mathrm{QF}$ provisions are justified.

There are also those who believe that, while PURPA repeal might and probably would be warranted in a competitive electricity supply scenario, we are not there yet. Just as some PUHCA reformers are against immediate piecemeal and standalone action, some PURPA reformers believe that repeal should be included in a comprehensive restructuring bill. They argue that there is no need to push a repeal bill through Congress when there is currently other proposed electricity competition legislation that will comprehensively address the restructuring and regulatory issues that warrant legislative action.

\section{Proposed Comprehensive Energy Restructuring Bills}

Several legislative proposals pending before the 104th Congress were considered comprehensive energy restructuring bills. In addition to PUHCA and PURPA repeal or reform, they dealt with multiple restructuring issues, such as stranded cost recovery, mergers, market power, and divestiture of utility assets. These bills were aimed at providing a national focus for the electric power industry's competitive evolution. There are strong arguments both for and against this type of legislation. Supporters say it remedies the unappealing piecemeal approach of dealing with the critical issues that have appeared and will continue to appear during the transition. Opponents contend that it is not wise to rush into such uncharted territory, but rather that we should deal with each issue as it arises. Following is a brief summary of the content of each bill.

\footnotetext{
66 This is the concept of "sustainable development," which refers to ways of social, economic, and political progress that meet the needs of the present without compromising the ability of future generations to meet their needs. Sustainable development points to ways that the economy can continue to develop without destroying the environment.
} 


\section{Green Pricing}

Utilities can encourage the development of renewable energy through "green pricing" programs for residential, commercial, and industrial consumers, and at the same time measure support for renewables under competitive conditions. ${ }^{\text {a }}$ These programs offer a potential market solution to the funding of future renewable technologies, in which electricity consumers would voluntarily pay for renewable energy development. For instance, consumers willing to pay a price premium for renewable energy could do so by participating in a program that allows them to add some incremental amount of money to their regular electricity bills or another program which rounds up consumers' bills to the nearest dollar, with the added quantity going to support renewable energy. ${ }^{b}$ According to the Natural Resources Defense Council, power generated today through green pricing programs in the United States is nearly 2 megawatts. ${ }^{C}$ In a competitive environment, however, there is a question of the degree of impact there will be on renewable development if green pricing program participants choose another electricity supplier.

To date, approximately 10 utilities have introduced green pricing programs: ${ }^{d}$

- Public Service Co. of Colorado (PSCO1). The Renewable Energy Trust (RET) Program supports the accelerated growth of renewable generation construction through voluntary monthly pledges.

- Public Service Co. of Colorado (PSCO2). The RET Round-Up Program rounds customers' monthly bills up to the nearest dollar to support renewable electric generation.

- Wisconsin Public Service Corp. (WPS). The SolarWise for Schools Program collects monthly pledges to support the construction of photovoltaic systems on high-school rooftops.

- Gainesville Regional Utilities (GRU). Monthly pledges or one-time donations support a photovoltaic electric generation system.

- Sacramento Municipal Utility District (SMUD). The PV Pioneers Program installs photovoltaic systems on consumers' roofs for a $\$ 4.00$ monthly premium. Participation has been restricted by the utility.

- Traverse City Light and Power (TCLP). The Green Rate Wind Project supplies consumers with electricity from a 600-kW wind turbine for 8.3 cents $/ \mathrm{kWh}$ (a $1.58 \mathrm{cent} / \mathrm{kWh}$ premium). Subscriptions last for 3 years. The program received the American Public Power Association's ENERGY Innovator of the Year award in 1995.

- Detroit Edison (DE). The SolarCurrents Program allows consumers to purchase a share of capacity in a photovoltaic system at a net monthly cost of approximately $\$ 6.59$ for each 100 -watt increment. The typical participant purchases 150 watts. Participation has been restricted by the utility.

- Niagara Mohawk Power Corp. (NM). The GreenChoice Program charges a fixed premium of $\$ 6.00$ per month. Five-sixths of the net funds are spent on renewable energy projects, and one-sixth is spent on tree planting.

- Northern States Power (NSP). The Solar Advantage Program chose 17 of 250 residential consumers who were willing to pay $\$ 50$ per month to have a $2 \mathrm{~kW}$ photovoltaic system installed on their rooftops. NSP pays for, installs, and maintains the system and participants must sign up for 5 years. At the end of that time, customers have three options: (1) sign another 5 -year contract, at the end of which they may purchase the system for $\$ 1$; (2) purchase the system from NSP for $\$ 3,000$; or (3) have NSP remove the system.

- Wisconsin Electric Power Company (WEPCO). WEPCO gives customers the option of purchasing 100, 50, or 25 percent of their electricity at an additional rate of 2.04 cents per $\mathrm{kWh}$ from hydro dams operated by Manitoba Hydro and Ontario Hydro and a Minnesota Power \& Light biomass plant that burns wood pulp that would otherwise go in a landfill. A customer with a $\$ 40$ monthly bill will pay a premium of $\$ 12, \$ 6$, or $\$ 3$ depending on the level chosen.

\footnotetext{
${ }^{a}$ "NRDC Analysis Finds Green Pricing Programs Total Less Than 2 MW," Utility Environment Report (April 12, 1996$)$, p. 14.

'Energy Information Administration, Renewable Energy Annual 1995, DOE/EIA-0603(95) (Washington, DC, December 1995), p. xxx; and B. Byrnes, M. Rahimzadeh, R. de Alba, and K. Baugh, "Green Pricing: The Bigger Picture," Public Utilities Fortnightly (August 1996), pp. 18-19.

In the past, green pricing programs have targeted the residential consumer, but now commercial and industrial consumers have shown interest. The green pricing programs available for commercial and industrial consumers are not the same, in many cases, as those offered to residential consumers.

"The first eight of the following descriptions are reproduced from B. Byrnes, M. Rahimzadeh, R. de Alba, and K. Baugh, "Green Pricing: The Bigger Picture," Public Utilities Fortnightly (August 1996), p. 20. For additional information, refer to B. Byrnes, M. Rahimzadeh, R. de Alba, and K. Baugh, "Green Pricing: Removing the Guesswork," Public Utilities Fortnightly (August 1995), pp. 26-28. The last two descriptions are excerpted from a fact sheet provided by the Regulatory Assistance Project in Gardiner, ME.
} 


\section{S. 1526, "Electricity Competition Act of 1996"}

This bill, introduced into the Senate by Senator J. Bennett Johnston (D-LA) on January 25, 1996, would require States to conduct proceedings to examine their local power markets and either set up competitive wholesale procurement markets, establish retail access programs for all consumers, or devise their own programs as long as they do not allow utilities to unduly favor their own generation and do not subject consumers to abovemarket energy costs. (Utilities not regulated by FERC or the States must conduct similar proceedings on their own.) State plans would have to be in effect 18 months after enactment of the legislation. States that choose retail wheeling must have it in place by 2002 . Otherwise, retail wheeling for all must be in effect by 2010-a date that is subject to change, depending on the consensus of the industry. In exchange, utilities would be able to collect all their legitimate, verifiable, and prudently incurred stranded costs. On the retail level, those costs would be determined by the States, with guidance by FERC. And if the States do not give the utilities full recovery of those costs, the utilities may take their cases to FERC

\section{H.R. 2929, "Electric Power Competition Act of 1996"}

Introduced into the House of Representatives by Congressman Edward J. Markey (D-MA) on February 1, 1996, this bill would provide incentives for State regulated utilities and regulatory commissions to remove barriers to effective competition in the electricity industry. The bill would remove the mandatory purchase obligation of PURPA in those instances where the State commission certified that the utility met specific competition standards. It also provides for States to promote renewable energy resources and would protect existing contracts under PURPA. In addition, it would remove the "State action" exemption from Federal anti-trust statutes where utilities were subject to effective competition in electricity generation. Title I would suspend application of PURPA if an electric utility receives a certification of competition from its State regulatory commission. In addition, it would preserve existing PURPA contracts between utilities and QFs and would expressly permit a State to favor particular types of generation (e.g., renewables) in determining avoided cost under PURPA. Title II would establish Federal standards for utilities in order to receive a certification of competition from a State regulatory authority.

\section{H.R. 3782, "Electric Power Competition and Consumer Choice Act of 1996"}

This companion bill to H.R. 2929 was introduced into the House of Representatives by Congressman Edward J. Markey (D-MA) on July 11, 1996. This bill is aimed at promoting competition in the electric utility industry and would link any repeal of PUHCA to State action to introduce full retail competition in electricity generation. In addition, it is aimed at addressing the risks that electric utility mergers, utility market power, or utility diversification into new lines of business might harm electricity consumers or undermine the emergence of a fully competitive electricity generation market. In general, it would:

- Require each State to initiate a retail competition rulemaking proceeding pursuant to certain Federal standards

- Repeal PUHCA for those electric utility holding companies whose service territories have been opened up to full retail competition and have met minimum standards for renewables, efficiency, and low-income consumer protections

- Give FERC and the States enhanced authority to regulate utility mergers and acquisitions to protect consumers from transactions that are inconsistent with effective competition in electricity markets or would increase electricity prices

- Give FERC and the States authority to regulate utility market power to guard against anticompetitive practices

- Grant FERC and the States authority over electric utility interaffiliate transactions to guard against cross-subsidization or self-dealing

- Direct FERC to establish regional transmission markets to assure functionally efficient and nondiscriminatory transmission and prevent "pancaking" of rates

- Assure that FERC and State regulators have full access to electric utility books and records.

\section{H.R. 3790, "Electricity Consumers' Power to Choose Act of 1996 "}

This bill, introduced into the House of Representatives on July 11, 1996, by Congressman Dan Schaefer (R-CO), would give all consumers of electricity the right to choose 
among competitive suppliers of electricity services no later than December 15, 2000. It would also repeal both PUHCA and PURPA. In addition, it would establish a national renewable energy credit trading system to encourage development of electricity generated from renewable energy sources, specifying that all generators of electricity selling power are to have renewable energy credits equal to 2 percent of their generation-increasing to 4 percent by the year 2010. According to a news item released simultaneously with introduction of this bill, "There is not a single mandate on states in this bill. State municipalities and rural cooperatives will have full discretion to decide whether or not to implement retail choice for their ratepayers by the date certain. If they decide not to implement retail choice for their citizens, FERC is directed to do so for them."

\section{H.R. 4297, "Consumers Electric Power Act"}

This bill, introduced by House Majority Whip Tom DeLay (R-TX) on September 28, 1996, would guarantee that all consumers have the right to choose their electricity service provider by January 1, 1998, and would ensure that providers are allowed to compete on a level playing field. The legislation would preserve and strengthen State authority with regard to universal service for consumers, universal access for providers, conservation programs, and future economic development programs. In addition, it would outline the performance objectives of transmission and distribution systems in a competitive environment. After competition is affirmatively achieved, the proposal would prospectively repeal PUHCA and PURPA.

\section{In the Planning Stages}

According to an article in Electric Utility Week on September 23, 1996, Senator Dale Bumpers (D-Ark) "has ordered his staff to begin crafting comprehensive legislation to restructure the electric industry." Details or a framework for the planned legislative proposal may be available by the end of this year.

\section{Other Relevant Legislation}

\section{H.R. 3172, "Clean Power Production Act"}

Introduced by Congressman Patrick J. Kennedy (D-RI) into the House of Representatives on March 27, 1996, this bill proposed establishment of a commission to develop strategies and policies to mitigate the environmental impacts associated with electric utility restructuring. Although it does not address proposals concerning how to restructure or deregulate the industry, it is salient in that it proposes a means of ensuring that there will be no significant diminution in the quality of the national and global environment as a consequence of restructuring. It states that "the opportunities for increased competition offer potentially significant economic benefits to all classes of consumers; however, there remains a substantial risk of increased emissions and environmental damages due to changed operating procedures and market characteristics among electricity utility generators. ${ }^{\prime \prime 7}$ In addition, it points out that, while "there have been a number of proposals among States for mitigating the environmental impacts of electric utility restructuring ... no regional or national mitigating strategies and policies have been developed or implemented." ${ }^{68}$

The proposed legislation calls for the Administrator of the Environmental Protection Agency (EPA) to undertake and submit within 6 months an assessment of environmental impacts associated with restructuring and, in doing so, to consult with the Secretary of Energy, the Chair of FERC, the Chair of the Council on Environmental Quality, and other Federal and State agency officials as appropriate. The EPA Administrator and the Secretary of Energy would then establish and co-chair the Commission for Environmental Mitigation of Electric Utility Restructuring, which would include representatives from the Council on Environmental Quality, FERC, and the Council of Economic Advisors. Using the aforementioned assessment, the Commission would develop strategies and policies to mitigate the environmental impacts associated with electric utility restructuring. Within 12 months after enactment of the Act, the Commission would submit a report to Congress containing the recommendations for strategies and policies.

\section{H.R. 4316 ( Not Yet Titled)}

This bill was introduced by Congressman Frank Pallone (D-NJ) into the House of Representatives on September 28, 1996. It would amend the Federal Power Act to provide a moratorium on the retail wheeling of electric energy until the Clean Air Act is amended to reduce significantly certain transboundary air pollution associated with ozone and ozone precursors, PM-10, mercury, and carbon dioxide. It stipulates that neither FERC nor any State may permit any person to enter into an arrangement for the sale of electric energy in

${ }^{67}$ H.R. 3172, "The Clean Power Production Act," Section 2(3) (introduced March 27, 1996).

${ }^{68}$ Ibid. 
state commerce to a retail electric consumer located within the exclusive service territory of a State-regulated or nonregulated electric utility serving retail consumers in that State.

\section{Public Law 104-58, "Alaska Power Administration Asset Sale and Termination Act"}

The idea of the Federal Government removing itself from the electricity business by selling off its power marketing administrations (PMAs) has recently reappeared. There are five such Federal PMAs: The Alaska Power Administration, the Southeastern Power Administration, the Southwestern Power Administration, the Western Area Power Administration, and the Bonneville Power Administration. The marketing and transmission of electric power produced at Federal hydroelectric projects and reservoirs is carried out by the PMAs, which are under the jurisdiction of the Department of Energy. One law has already been enacted-the Alaska Power Administration Asset Sale and Termination Act, passed on November 28, 1995. It authorized and directed the Secretary of Energy to sell the Alaska Power Administration, which is composed of the Eklutna Hydroelectric Project and the Snettisham Hydroelectric Project. Proceeds from the sale were to be deposited in the Treasury of the United States to the credit of miscellaneous receipts. It also authorized the export of Alaska North Slope crude oil.

\section{Other Federal PMA Privatization Proposals}

Other legislative proposals related to the abovementioned Act have been drafted and will be debated in Congress. H.R. 1801, the Federal Power Asset Privatization Act of 1995, introduced by Congressman Mark A. Foley (R-FL) on June 5, 1995, would privatize certain Federal power generation and transmission assets. H.R. 3878, introduced by Congressman Gary Franks (R-CT) on July 23, 1996, would privatize the Federal PMAs and certain facilities of the Tennessee Valley Authority (TVA) and, in the interim, would provide for a transition to market-based rates for such power. H.R. 310, the Federal Power Administration Privatization Act of 1995, introduced by Congressman Scott Klug (R-WI) on January 4, 1995, directed the President to develop a plan for selling all of TVA's assets and offered an amendment to the energy and water appropriations bill to kill the $\$ 103$ million TVA Federal subsidy. The subsidy bill did not reach the floor, and the TVA sale bill failed in a House vote, 144 to 248 .

\section{Relevant Tax Issues}

While no legislative proposals have been made as yet that would specifically address Federal income tax rules that affect only electric utilities, such legislation may be forthcoming in light of the industry's move to a competitive environment. According to the National Council on Competition and the Electric Industry, ${ }^{69}$ competition will undoubtedly have a major impact on Federal, State, and local tax structures.

Electric utilities pay gross receipts taxes, net income taxes, property taxes, and franchise fees to their respective State and local governments. If electricity prices and utility property values decrease as a result of competition, cities could lose millions of dollars in tax revenues. One study by the Massachusetts Alliance of Utility Unions stated that "deregulation jeopardizes $\$ 87$ million in tax revenues for 82 cities and towns in Eastern Massachusetts. ${ }^{\prime 70}$

Utilities also collect sales and use taxes and utility user taxes from their customers and, in turn, remit them to the proper taxing authority. Under competition, these "taxes that have been passed through to customers as higher electricity rates will be borne to an increasing extent by the utilities themselves and will affect who provides electricity and where it is generated. ${ }^{\prime 71}$

At the Federal level, utilities currently receive two tax benefits-accelerated depreciation and the investment tax credit-because they are regulated on a cost-ofservice basis. This regulation also means that income tax expenses are calculated and charged to consumers in

\footnotetext{
69 The National Council on Competition and the Electric Industry is a joint project of the National Association of Regulatory Commissioners and the National Conference of State Legislatures. Members include the Department of Energy and the Environmental Protection Agency. The Council has commissioned a series of papers to provide information regarding the complex issues surrounding competition in the electricity industry. For further information surrounding the tax issue, refer to the first paper in their series, Federal, State and Local Tax Implications of Electric Industry Restructuring. Their subsequent papers include Assessing Impacts of Restructuring on Small-Business, Residential and Low-Income Customers; The Unintended Impacts of Restructuring; The Organization of Competitive Wholesale Power Markets and Spot Price Pools; Stranded Benefits in Electric Utilities Restructuring; The British Electric Utility Restructuring Experience: History and Lessons for the United States; and their forthcoming paper, Regulation and Competition Without Privatization: Norway's Experience.

70 D. Chmielewski, "Darker Side of Utility Deregulation: Lost Taxes," The Patriot Ledger (February 28, 1996), p. 10.

${ }^{71}$ National Council on Competition and the Electric Industry, Federal, State and Local Tax Implications of Electric Utility Industry Restructuring (Dallas, TX: Deloitte \& Touche LLP, October 1996), p. xi.
} 
their rates. Under deregulation, these Federal tax rules will have to be readdressed by policymakers. Also, the rules concerning the current deduction for the funding of nuclear decommissioning may have to be revised. Other tax-related issues that will have to be taken into account are "the timing and amount of any tax return deductions for utility property made uneconomic under market conditions ... [and the fact that] ... the use of a publicly owned utility's transmission system for the benefit of third parties may jeopardize the tax-exempt status of its bonds. . . . ${ }^{\prime 72}$ While access to more transmission lines could expand a municipal utility's consumer base by allowing entrance to a wider region, the utility may be ordered to increase its own transmission line network to adapt to the needs of other power companies to satisfy a reciprocity condition stated in FERC Order 888. The extra money (debt) required could influence the utility's creditworthiness. Also, utilities "could lose their taxexempt status by deriving more than 10 percent of their revenues from power sales and/or transmission rights to private utilities."

All of the proposals mentioned in this chapter are summarized in Table 4, which is provided as a quick reference to recently introduced legislation dealing with the changing structure of the electric power industry. A detailed discussion of the Federal role, as well as the role of State governments, in promoting competition in the industry is presented in the following chapter.

72 Ibid., pp. xi-xii.

${ }^{73}$ H. J. Eurich, "Nuveen: New U.S. Rules Could Help, Hurt Utilities and Localities," The Bond Buyer (September 26, 1996), p. 5. For more information, refer to M. M. Canan, "As Public Power Faces Competition, Effects on Bonds Unclear," The Bond Buyer (March 29, 1996), p. 5, and M. M. Canan, "Utilities' Use of Tax-Exempts Requires Review, Clinton Says," The Bond Buyer (February 20, 1996), p. 1. 
Table 4. Proposed Legislation Influencing the Restructuring of the Electric Power Industry Introduced During the 104th Congress

\begin{tabular}{|c|c|}
\hline Bill & Purpose/Sponsor \\
\hline $\begin{array}{l}\text { H.R. } 310 \\
\text { "Federal Power Administration } \\
\text { Privatization Act of 1995" }\end{array}$ & $\begin{array}{l}\text { To provide for the privatization of the Federal Power Marketing Administrations, and } \\
\text { for other purposes. } \\
\text { Introduced by Representative Scott Klug (R-WI) on January 4, 1995, and referred to } \\
\text { the Subcommittee on Water and Power Resources. }\end{array}$ \\
\hline $\begin{array}{l}\text { S.708 } \\
\text { "Electric Utility Rate Payer Act" }\end{array}$ & $\begin{array}{l}\text { To repeal Section } 210 \text { of the Public Utility Regulatory Policies Act of } 1978 . \\
\text { Introduced by Senator Don Nickles (R-OK) on April 6, 1995, and referred to the } \\
\text { Senate Committee on Energy and Natural Resources. }\end{array}$ \\
\hline $\begin{array}{l}\text { H.J. RES. } 178 \\
\text { (No title) }\end{array}$ & $\begin{array}{l}\text { A joint resolution disapproving Orders Nos. } 888 \text { and } 889 \text { of the Federal Energy } \\
\text { Regulatory Commission. } \\
\text { Introduced by Representative Mark Foley (R-FL) on June 8, 1995, and referred to the } \\
\text { Subcommittee on Energy and Power. }\end{array}$ \\
\hline $\begin{array}{l}\text { H.R. } 1801 \\
\text { "Federal Power Asset Privatization } \\
\text { Act of 1995" }\end{array}$ & $\begin{array}{l}\text { To privatize certain Federal power generation and transmission assets, and for other } \\
\text { purposes. } \\
\text { Introduced by Representative Mark A. Foley (R-FL) on June 8, 1995, and referred to } \\
\text { the Subcommittee on Water and Power Resources. }\end{array}$ \\
\hline $\begin{array}{l}\text { S.1526 } \\
\text { "Electricity Competition Act of } \\
1996 "\end{array}$ & $\begin{array}{l}\text { To provide for retail competition among electric energy suppliers, to provide for } \\
\text { recovery of stranded costs attributable to an open access electricity market, and for } \\
\text { other purposes. } \\
\text { Introduced by Senator J. Bennett Johnston (D-LA) on January } 25,1996 \text {, and referred } \\
\text { to the Senate Energy and Natural Resources Committee. }\end{array}$ \\
\hline $\begin{array}{l}\text { H.R.2929 } \\
\text { “Electric Power Competition Act of } \\
\text { 1996" }\end{array}$ & $\begin{array}{l}\text { To amend Title I of the Public Utility Regulatory Policies Act of } 1978 \text { to deregulate the } \\
\text { electric power industry. } \\
\text { Introduced by Representative Edward J. Markey (D-MA) on February 1, 1996, and } \\
\text { referred to the House Committee on Commerce and to the House Committee on the } \\
\text { Judiciary. }\end{array}$ \\
\hline $\begin{array}{l}\text { H.R.3172 } \\
\text { "Clean Power Production Act" }\end{array}$ & $\begin{array}{l}\text { To establish a Commission to develop strategies and policies to mitigate the } \\
\text { environmental impacts associated with electric utility restructuring. } \\
\text { Introduced by Representative Patrick J. Kennedy (D-RI) on March 27, 1996, and } \\
\text { referred to the House Committee on Commerce. }\end{array}$ \\
\hline
\end{tabular}


Table 4. Proposed Legislation Influencing the Restructuring of the Electric Power Industry Introduced During the 104th Congress (Continued)

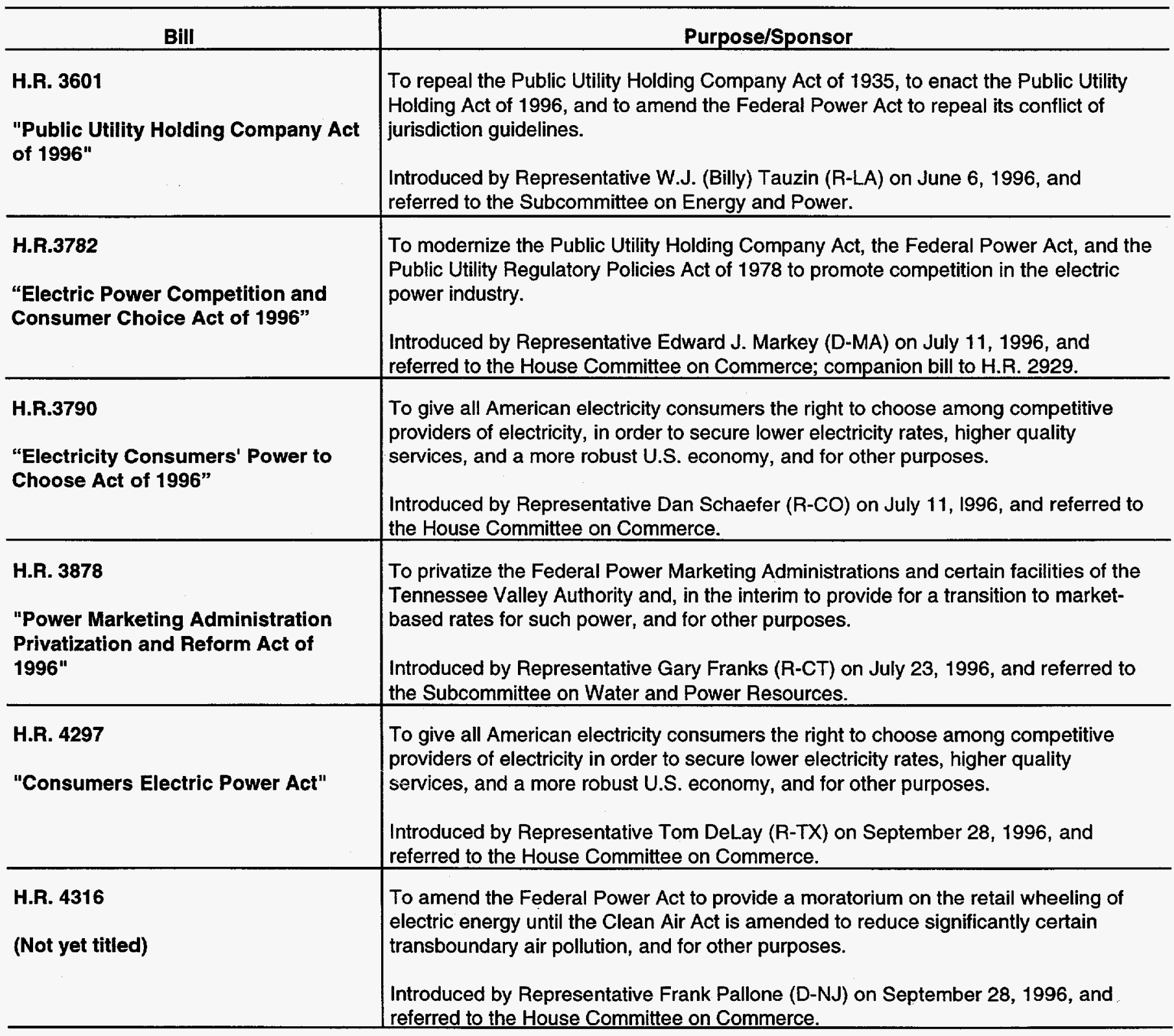

Note: At the end of every session of Congress, if a bill does not become a law, it must be reintroduced during the next session for consideration. The proposed legislation introduced during the 104th Congress contained in this table may or may not be reintroduced into the 105th Congress as is. A bill may be reintroduced with major revisions, or the legislation may become part of another bill.

Source: Energy Information Administration, Office of Coal, Nuclear, Electric and Alternate Fuels. 


\section{Evolving Regulatory Reform: The Federal and State Role in Promoting Competition}

This chapter provides information about measures initiated at the Federal and State levels to promote competition in the domestic electricity industry. Because changes are taking place rapidly at the State level, the information concerning them is for the period ended June 30, 1996.

The Energy Policy Act of 1992 (EPACT) overhauled provisions of the Federal Power Act (FPA) governing availability of transmission services to other producers by instructing the Federal Energy Regulatory Commission (FERC) to order wholesale wheeling of electricity if such an order does not violate State laws or affect reliability (Section 721, Title VII - Electricity, Subtitle B - Federal Power Act: Interstate Commerce in Electricity). For this objective to be achieved, EPACT expanded FERC's authority in Section 211 of the FPA to order transmission services upon application. ${ }^{74}$

EPACT also authorized FERC to set transmission rates at levels that permit the recovery of all costs incurred in connection with the transmission services, including legitimate, verifiable, and economic costs-subject to the requirement that these costs be recovered from the applicant (seeking transmission services) and not from the transmitting utilities' existing customers. ${ }^{75}$ This provision protects the utilities' existing customers (or "native load" customers) and opens the way for opportunity cost pricing. ${ }^{76} \mathrm{EPACT}$ 's provisions pertaining to electricity are designed primarily to encourage the electric power industry to rely increasingly on market forces instead of cost-based regulation. As the process gains momentum, efficiency and welfare gains should result. ${ }^{77}$

\section{FERC's Role in Promoting Competition in Wholesale Power}

Even before the passage of EPACT in 1992, FERC played a critical role in the competitive transformation of wholesale power generation in the electric power industry. ${ }^{78}$ Specific initiatives include notices of proposed rulemaking (NOPRs) issued in 1988 that proposed steps toward the expansion of competitive wholesale electricity markets. Even though FERC withdrew these NOPRs in 1990, the underlying interest at FERC in promoting competition was evident. ${ }^{79}$ A task force report dealing with transmission issues, released in 1989, concluded that availability of transmission access was essential for a competitive wholesale power market. ${ }^{80}$ FERC also conditioned its approval of certain mergers upon transmission access with a view to mitigate anti-competitive effects. In some other cases, FERC allowed customers to gain access to transmission services to reach competing suppliers. ${ }^{81}$ These actions supported the trend to promote wholesale competition initiated by the passage of the Public Utility Regulatory Policies Act (PURPA) in $1978 .^{82}$

${ }^{74}$ Title VII of EPACT (Electricity) is reproduced in Appendix F.

${ }^{75}$ EPACT provisions prohibit FERC from issuing orders that are inconsistent with any State law which exclusively governs the retail marketing areas of the electric utilities.

${ }_{76}$ A firm's opportunity cost of producing a good is the best alternative that the firm foregoes to produce it. Equivalently, opportunity cost is the firm's best alternative use for the factors of production employed to produce the good.

77 In its Mega-NOPR (see below), FERC points out that new generation facilities can produce power on the grid at a cost of 3 to 5 cents per kWh, yet the costs for large plants constructed and installed over the last decade were 4 to 7 cents per $\mathrm{kWh}$ for coal plants and 9 to 15 cents for nuclear plants.

${ }_{78}$ For additional details refer to Initial Comments of Edison Electric Institute before the Federal Energy Regulatory Commission, Docket RM94-7-000, filed on December 9, 1994.

${ }_{79}$ Charles G. Stalon, "An Assessment of the Electric Industry Restructuring Debate," paper presented at Transportation and Public Utility Group, American Economic Association (New Orleans, LA, January 1992).

${ }^{80}$ Federal Energy Regulatory Commission, The Transmission Task Force's Report to the Commission-Electricity Transmission: Realities, Theory and Policy Alternatives (Washington, DC, October 1989).

${ }_{81}$ Generally speaking, four different types of entities seek access to the grid. These are retail consumers, integrated utilities, wholesale consumers, and captive independent suppliers. Federal Energy Regulatory Commission, The Transmission Task Force's Report to the Commission (Washington, DC, October 1989), p. 31.

${ }^{82}$ Note that PURPA's intent to facilitate increased diversity in power generation, to foster increased usage of renewable technologies, and to reduce consumption of oil and gas is viewed only as a "qualified success" and not an unqualified one. U.S. Congress, Subcommittee on Energy and Power of the Committee on Commerce, Oversight Hearings on the Public Utility Regulatory Policies Act and Its Role in the Increasingly Competitive Electricity Markets (104th Congress, Second Session, February 1996), p. 13. 
FERC also initiated a number of proceedings in the period immediately following the passage of EPACT in $1992 .{ }^{83}$ The Commission, with its experience in promoting competition in the natural gas industry, was moved into action to provide a regulatory framework for dealing with utility assets likely to be stranded during a transition into a competitive economy. To address this issue, FERC approved a proposed rulemaking to provide a regulatory framework for dealing with wholesale and retail stranded costs by public utilities and transmitting utilities. FERC's NOPR, entitled "Recovery of Stranded Costs by Public Utilities and Transmitting Utilities," issued on June 29, 1994, sought public comments concerning the issues raised by the proposed rulemaking. ${ }^{84}$

\section{Defining Wholesale and Retail Stranded Costs}

The NOPR defines wholesale stranded costs ${ }^{85}$ as "any legitimate, prudent and verifiable costs incurred by a public utility or a transmitting utility to provide a service to a wholesale requirement customer that subsequently becomes, in whole or in part, an unbundled transmission services customer of that public utility or transmitting utility." ${ }^{\prime 86}$ Similarly, retail stranded costs are defined as "any legitimate, prudent, and verifiable costs incurred by a public utility or a transmitting utility to provide a service to a retail franchise customer that subsequently becomes, in whole or in part, an unbundled transmission services customer of that public utility or transmitting utility."

Stranded costs emerge because new generating capacity can currently be built and operated at costs that are lower than many utilities' embedded costs. Wholesale and retail customers have, therefore, an incentive to turn to lower cost producers. Such actions make it difficult for utilities to recover all their prudently incurred costs in generating facilities. Based on this possibility, estimates of potential stranded costs vary. Some exceed $\$ 200$ billion or more. These estimates are based, to a large degree, on the difference between the book value of generating assets and their presumed market value. ${ }^{87}$

Stranded costs can occur during the transition to a fully competitive wholesale power market as some wholesale customers leave a utility's system to buy power from other sources. This may idle the utility's existing generating plants, imperil its fuel contracts, and inhibit its capability to undertake planned system expansion leading to the creation of "stranded costs."

The Commission noted that during the transition to a fully competitive wholesale power market, some utilities may incur stranded costs as customers switch to other suppliers. ${ }^{88}$ If power previously sold to a departing wholesale customer cannot be sold to an alternative buyer, or if other means of mitigating the stranded costs cannot be found, the options for recovering stranded costs are limited. These costs must be recovered from either the departing customer or the remaining customers or borne by the utility's shareholders. These comments are applicable with equal force in cases of retail stranded costs.

The Commission recognized that there were three ways in which stranded costs were most likely to occur as a result of the transition to the wholesale power market:

- Wholesale customers leaving the system

- Wholesale customers leaving the system

- Retail-turned-wholesale customers leaving the system

83 These proceedings include: (1) Stranded Cost NOPR, Docket No. RM94-7-000 (June 6, 1994), (2) Transmission Pricing Policy Statement, Docket No. RM93-19-000 (October 26, 1994), (3) Pooling Notice of Inquiry, Docket No. RM94-20-000 (October 26, 1994), (4) Regional Transmission Group (RTG) Policy Statement, Docket No. RM93-3-000 (July 30, 1993), and (5) Notice of Inquiry on Merger Policy, Docket No. RM96-6-000 (January 31, 1996).

${ }^{84}$ Federal Energy Regulatory Commission, Docket No. RM94-7-000, Recovery of Stranded Costs by Public Utilities and Transmitting Utilities (Washington, DC, June 29, 1994).

85 Other terms used to describe stranded costs include: uneconomic sunk costs, transition costs, unmarketable costs, strandable costs, and stranded investments.

${ }_{86}$ An unbundled transmission services consumer, as defined in the NOPR, is one who purchases transmission as a product that is separate from the purchase of generation.

87 Federal Energy Regulatory Commission (FERC), Recovery of Stranded Costs by Public Utilities and Transmitting Utilities, Docket No. RM-94-7000, p. 20. These estimates include both wholesale and retail stranded costs. FERC, however, noted that retail stranded costs may be significantly higher than the wholesale stranded costs, given that only 10 to 15 percent of generating investment (of the investor-owned utilities) is in the wholesale rate base.

88 Wholesale power market transactions include purchases, sales for resale, exchanges and wheeling (i.e., transmission services). These transactions may be divided into two broad categories: requirement and coordination transactions. Wholesale requirement contracts involve firm sales of capacity, meaning that either the associated energy will be taken by the purchaser or the purchaser will pay for the capacity (i.e., the demand charge) when the energy is not taken. Requirement contracts may involve utilities that have either insufficient or no generating capability to satisfy their customer load. The duration of sale and the type of capacity sold are key factors in determining the type and value of the transactions. Coordination transactions are for short periods, are subject to curtailment, and rarely have a capacity charge in the price. 
- Retail customers leaving the system.

In order to alleviate concerns regarding the future financial viability of the investor-owned utilities, the Commission viewed an early consideration of stranded cost recovery as critical to both buyers and sellers of electric energy and transmission. ${ }^{89}$ This emphasis results from the conceptual underpinnings of the traditional regulatory compact, which ensures a utility's financial integrity by permitting recovery of prudently incurred costs plus a fair rate of return in exchange for regulation of its franchised territory and the associated obligation to provide reasonably priced electricity on demand. In addition, the Commission contended that the issue of stranded costs should be resolved in as short a time as possible.

With regard to the recovery of wholesale stranded costs, the Commission differentiated between existing contracts (i.e., contracts executed on or before issuance of the NOPR) and new contracts (i.e., contracts executed after the publication of the NOPR on July 11,1994). Recovery of stranded costs for the latter category could be sought only if the contract provisions explicitly provided for it. For existing wholesale requirement contracts that do not explicitly provide for the recovery of stranded costs, there would be a 3-year transition period during which the utilities would attempt to renegotiate these contracts (including the recovery of stranded costs through transmission rates). ${ }^{90}$ State regulatory authorities were expected to deal with the retail stranded cost issues.

Where a conflict may arise between States or within a State, the Commission may entertain requests toward the recovery of retail stranded costs. The Commission may, however, also decide not to entertain any request on this issue.
Failure to address the stranded cost issue, according to the Commission, could harm the public interest in two ways. First, there may be an impairment of a utility's financial capability to continue providing reliable service, depending on the magnitude of stranded costs. Second, permitting customers to leave without paying stranded costs would impose an inequitable burden on captive customers.

The Commission's NOPR provides a jurisdictional analysis in support of the proposed rulemaking to include wholesale transmission and retail transmission activities. Based on these considerations, the Commission sought public comments on amending its regulations concerning the recovery of wholesale and retail stranded costs by public and transmitting utilities under Sections 205, 206, 211, and 212 of the Federal Power Act. ${ }^{91}$ Comments and reply comments on the proposed rulemaking were invited within a 60-day and a 90-day period following publication of the NOPR in the Federal Register.

\section{The Mega-NOPR}

With a view to achieving its stated goal of encouraging lower electricity prices by structuring an orderly transition to competitive bulk power markets, FERC proposed additional sweeping changes by releasing what is now called the "Mega-NOPR." twin goals: (1) to facilitate the development of bulk power markets by ensuring that wholesale purchasers of electric energy and wholesale sellers of electricity can reach each other by eliminating anti-competitive practices and undue discrimination in transmission services and (2) to address the transition costs associated with the development of competitive wholesale markets. Thus, the most critical element is the issue of open access to transmission

\footnotetext{
89 While the Commission's focus is to look at stranded costs relative to generating capacity, a somewhat broader consideration of stranded costs would include fuel supply costs, purchased power costs, nuclear decommissioning costs, regulatory assets, and other costs that may be stranded.

90 The NOPR provides guidance concerning the evidentiary demonstration that a public utility or transmitting utility must make to recover stranded costs. These include: (1) a utility must show that it incurred stranded costs based on an expectation that was reasonable when the costs were incurred that the applicable contract would be extended; (2) a utility must show that the stranded costs it incurred are not more than the customer would have contributed had the customer remained a wholesale customer of the utility; and (3) a utility must show that it has taken and will take reasonable measures to mitigate stranded costs.

91 A public utility is defined as any person who owns or operates facilities subject to the jurisdiction of the Commission. A transmitting utility is defined as any electric utility, qualifying cogeneration facility, qualifying small power production facility, or Federal Power Marketing Agency which owns or operates electric power transmission facilities which are used for sale of electric energy at wholesale.

92 Federal Energy Regulatory Commission, Notice of Proposed Rulemaking and Supplemental Notice of Proposed Rulemaking, issued on March 29, 1995. The NOPR is made up of two dockets: (1) Promoting Wholesale Competition Through Open Access Non-discriminatory Transmission Services by Public Utilities, Docket No. RM95-8-000, and (2) Recovery of Stranded Costs by Public Utilities and Transmitting Utilities, Docket No. RM94-7-001. The NOPR contains a detailed recapitulation of the various initiatives taken by the Commission to foster a competitive environment in the handling of bulk power markets. The narrative includes the Commission's aggressive implementation of Section 211, a new look at undue discrimination under the FPA, easing of market entry for sellers of electricity from new generation facilities, and the initiation of industry-wide reforms.
} 
facilities or what is commonly known as "mandatory wheeling" of electric power on nondiscriminatory terms. ${ }^{93}$ More specifically, under the Commissions's proposal: ${ }^{94}$

- All utilities under the Commission's jurisdiction would be required to file nondiscriminatory open access transmission tariffs, available to all wholesale sellers and buyers of electric energy.

- The utilities would be required to take service under the tariffs for their own wholesale sales and purchases of electric energy.

- The utilities would be allowed the opportunity to recover stranded costs.

In proposing the above rules designed to enable all electricity producers to have access to the grid on equal terms, the Commission's initiatives were intended to induce further growth of competitive market forces in the electric power industry. ${ }^{95}$ Under the proposed rules, the transmission utilities would be required to offer point-topoint and network transmission services, including ancillary services, to consumers comparable to the service they provide themselves. ${ }^{96}$ Utilities falling under the jurisdiction of the Commission will take service under the tariffs for their own wholesale sales and purchases of electric energy. Thus, the Commission's proposals required that utilities "functionally unbundle" their wholesale generation and transmission services without mandating the corporate separation of generation, transmission, and distribution functions. ${ }^{97}$

The Commission hoped that availability of open access to all participants would tend to eliminate transmission market dominance exercised by vertically integrated electric utilities. ${ }^{98}$ On the basis of its experience with respect to the deregulation of the natural gas industry, the Commission expected that, at a minimum, functional unbundling of wholesale services would be necessary for nondiscriminatory open access to be available. ${ }^{99}$

\section{Recovery of Stranded Costs}

In promoting the above transition to a competitive bulk power market, the Commission also recognized that utilities may not be willing participants in the absence of assurance concerning the recovery of stranded costs or investments. ${ }^{100}$ Accordingly, the Commission established the principle that utilities are entitled to a full recovery of

93 Wheeling implies the contracted use of facilities of one or more entities to transmit electricity for another entity. Because not all utilities voluntarily allow this facility to suppliers or purchasers of wholesale power, FERC's open access requirement is designed to ensure that the buyers and sellers have equal access to the transmission grid. These considerations give rise to the term "mandatory wheeling."

94 These rules were proposed by the Commission pursuant to its authority under Sections 205 and 206 of the Federal Power Act. Note that Section 206 applies primarily to public utilities. Since not all transmitting utilities are public utilities, the Commission invoked the application of Section 211 of the FPA as an additional means of promoting increased competition. The Mega-NOPR provides a detailed explanation with regard to the applicability of provisions of the FPA as relevant to the promotion of competition.

95 The layout of an electrical distribution system is called a "grid."

96 Ancillary services are those services necessary to support the transmission of electric power from seller to purchaser. These services range from actions taken to effect the transaction (such as scheduling and dispatching services) to services that are necessary to maintain the integrity of the transmission system (such as load following, reactive power support, and system protection services). Ancillary services are also needed to correct for effects associated with undertaking a transaction (such as loss compensation and energy imbalance services).

97 The term 'functional unbundling" implies that rates for transmission and ancillary services be stated in the open access tariff. Thus, a customer who buys both generation and transmission services should have separately stated rates for generation, transmission, and ancillary services on a nondiscriminatory basis; i.e., the utility should charge itself the same price for these services that other customers will have to pay. The Commission recognized that proposed unbundling may lead to two separate arrangements: one for wholesale transactions under its jurisdiction and the other for retail transactions governed by a State regulatory body. Currently, investor-owned utilities control all three functions under one corporate ownership. While these functions could be separated and placed under the control of different entities, FERC did not mandate such separations.

98 The Commission pointed out that dominance of market power leads to discriminatory treatment in various ways, such as network service, pricing, service priority, scheduling, or offering inferior ancillary services. Such discriminatory practices produce market distortions and undermine the goal of creating competitive bulk power markets.

99 Functional unbundling means three things: (1) A public utility must obtain transmission services, including ancillary services, for all of its new wholesale sales and purchases of electric energy under the same tariff with which it covers such services to others. (2) A transmission owner's tariff must include separately stated rates for transmission and ancillary service components. (3) A public utility must rely on the same electronic network that its consumers use to obtain transmission information about its system when buying or selling power. Meeting the above requirements will result in two separate arrangements: an explicit wholesale transmission tariff filed with the Commission and an implicit retail transmission tariff governed by the State regulatory body.

${ }^{100}$ In addition to the recovery of existing "uneconomic costs" primarily in generation, other transition costs (like fuel supply costs; purchased power costs, including QF costs; nuclear decommissioning costs; regulatory assets; and other utility obligations) are also included in the broader definition of stranded costs. Costs of certain social programs may also be included in this category. 
legitimate, prudent, and verifiable stranded costs at both the State and Federal levels. ${ }^{101}$

While maintaining that the approach initially proposed by the Commission (in its Stranded Cost NOPR of June 29, 1994) would adequately cover most costs that could be stranded due to the adoption of the Open Access NOPR, the Commission nevertheless made several preliminary determinations based on a review of the comments received:

- That recovery of legitimate and verifiable stranded costs should be allowed and that direct assignment of stranded costs to departing consumers would be the appropriate method for recovery in conformity with the cost causation principle

- That recovery of stranded costs associated with new wholesale requirements contracts should be allowed if explicitly provided for in the contract ${ }^{102}$

- That recovery of stranded costs should be allowed where existing wholesale requirements contracts are not renewed and do not contain exit fees or other stranded cost provisions but the seller is able to demonstrate that it had a "reasonable expectation" with regard to the renewal of the contract ${ }^{103}$

- That the States are expected to deal with stranded costs caused by retail wheeling, with the Commission stepping in only in cases where the State reglatory body lacks authority to address these issues

- That the Commission will provide mechanisms for stranded cost recovery due to municipalization or where retail consumers become wholesale customers. ${ }^{104}$
The Commission noted that the recovery of stranded costs is critical to the successful transition of a monopolistic industry regulated on a cost-of-service basis to an openaccess, competitively priced industry that will lower electricity prices. ${ }^{105}$ Failure to deal with this issue would merely delay and complicate the proposed industry transition. As an example, if the industry's shareholders were to shoulder the burden of stranded costs, the stability of the industry would be jeopardized. Since the rules under which the industry operated in the past are being radically altered, equity demands that utilities be allowed to recover prudently incurred costs.

The onus of identifying recoverable wholesale stranded costs rests on utilities. They are obligated to show that the stranded costs are not more than what the customer would have contributed in the event of not leaving the system. Within this framework, the utilities and customers both have some flexibility with regard to the period over which stranded cost liability would be determined.

Recovery of stranded costs is linked with the critical requirement that utilities take reasonable and prudent measures to mitigate stranded costs. FERC's initial Stranded Cost NOPR (June 1994) lists mitigation options that include marketing assets or giving the customer the option to market the generating capacity or supply of fuel or purchased power that forms the basis for the stranded cost charge. Any savings resulting from mitigation efforts are required to be credited to the account of departing customers. ${ }^{106}$

According to the Commission, recoverable wholesale stranded costs could best be calculated by the "revenues lost" approach, which encompasses mitigation measures

\footnotetext{
${ }^{101}$ The Commission reiterated its earlier definition of the "wholesale stranded cost" as "any legitimate, prudent and verifiable cost incurred by a public utility or a transmitting utility to provide service to: (1) a wholesale requirements customer that subsequently becomes, in whole or in part, an unbundled wholesale transmission services customer of such public utility or transmitting utility, or (2) a retail customer or a newly created wholesale power sales customer, that subsequently becomes, in whole or in part, an unbundled wholesale transmission services customer of such public utility or transmitting utility." In providing this definition, the Commission additionally sought comments with regard to the inclusion of stranded costs resulting from unbundled wholesale transmission for newly created wholesale customers.

${ }_{102}$ New wholesale requirements contracts are those that were executed after July 11, 1994. Existing wholesale power sales contracts are those executed on or prior to this date.

${ }^{103}$ The initial Stranded Cost NOPR proposed a 3-year transition period during which the utilities must attempt to renegotiate existing wholesale contracts that do not contain explicit provisions for stranded cost recovery. While reaffirming the need to renegotiate, the public utility or the customer could file a proposed stranded cost amendment prior to the expiration of the contracts not mutually renegotiated.

${ }^{104}$ Municipalization refers to the process by which municipalities, currently served at retail by existing utilities (whether they be investor-owned, government-owned, or cooperatives), form municipal utilities of their own and buy power from the wholesale market. For additional information, refer to Coopers and Lybrand, Electric Municipalization Review, 1996 (Philadelphia, PA, May 1996).

${ }^{105}$ The NOPR does take into account the arguments that stranded cost recovery would inhibit the movement toward competition, distort price signals, result in inefficient decisionmaking, and unfairly reward the least efficient utilities (like those with uneconomical nuclear power plants). To counter these arguments, the NOPR provides an explanation of why the recovery of legitimate stranded costs is critical to the transition process.

${ }^{106}$ The utilities in their comments distinguish between marketable and unmarketable stranded costs and maintain that mitigation strategies could not be applied to unmarketable stranded costs. Environmental cleanup costs, decommissioning costs, and regulatory assets are examples of unmarketable stranded costs, in contrast with stranded capacity, which is marketable.
} 
by reducing the amount of stranded costs recoverable by a utility by the market price of power that the customer no longer takes under its contract. ${ }^{107}$ The "revenues lost" approach further avoids the asset-by-asset review required by alternative cost-of-service approaches. ${ }^{108}$

\section{Retail Wheeling and Recovery of Stranded Costs}

In looking at the emergence of stranded costs in retail trade, the Commission viewed the problem as an exclusive State matter except in cases where the State regulatory authorities lack authority under State law to address the issue of stranded cost recovery at the time retail wheeling is required. The Commission made it clear that it will not ordinarily allow the States to use the interstate transmission grid for a pass-through for retail stranded costs. The Commission further noted that the States have a number of mechanisms available to them to address stranded costs resulting from retail customers who want to wheel in power from a different supplier. ${ }^{109}$

The Commission clarified the difference between its jurisdiction over transmission in "interstate commerce" and the States' jurisdiction over "local distribution." It upheld the view that the Commission had the jurisdiction over the rates, terms, and conditions of unbundled interstate transmission services by public utilities to retail customers, including the authority to address retail stranded costs over such services. At the same time, the States also have the authority to address retail stranded costs (or stranded benefits) through their jurisdiction over facilities used in local distribution. The Commission additionally provided several indicators to evaluate whether particular facilities in the case of vertically integrated transmission and distribution utilities are transmission or local distribution facilities.

\section{Implementation Procedures}

The Commission proposed a two-stage implementation process. In "Stage One," the Commission would place generic open access tariffs in effect simultaneously on a certain date ( 60 days after the Final Rule) for every public utility that owns and/or controls transmission facilities and would establish rates for each public utility based on the most current FERC Form 1 data. ${ }^{110}$ Both firm and nonfirm point-to-point transmission service and firm network transmission service on a nondiscriminatory open access basis will be included. ${ }^{111}$ In "Stage Two," utilities will have the option of proposing changes to the rates, terms, and conditions in the generic tariffs 61 days after the Final Rules go into effect. In addition, customers and others can file complaints seeking changes.

Concurrent with the issuance of the NOPR, the Commission also issued a Notice of Technical Conference and Request for Comments on establishing Real Time

\footnotetext{
107 Contributions to revenues attributable to variable costs are to be excluded in adopting the "revenues lost" approach. In addition, the scope of stranded costs was broadened to include other stranded costs, such as fuel supply costs, purchased power costs (including QF costs), nuclear decommissioning costs, regulatory assets, and other utility obligations. However, the utilities want many more elements to be included, such as construction work in progress, mandatory social program costs, clean air compliance costs, and others.

${ }^{108}$ Edison Electric Institute and the utilities proposed an asset-by-asset review of stranded investments (including contractual liabilities, regulatory assets, and certain social program costs) and the allocation of these costs among customers to determine a hypothetical cost-of-service measure of stranded cost liability. Some other commenters (including the American Public Power Association and the Electric Generation Association) advocate adopting a "netting" approach, in which recoverable stranded costs are the difference between embedded capital costs and the market value of assets. Methodology to compute stranded costs by using the "revenues lost" approach is described fully in another chapter of this report.

${ }^{109}$ In its initial NOPR on Stranded Costs, the FERC had identified the following: imposing an exit fee prior to, or as a condition of, creating the wholesale entity, or requiring an exit fee before a franchise customer is permitted to obtain unbundled retail wheeling; imposing a surcharge on local distribution rates; and State condemnation proceedings. Commenters to the NOPR identified several other mechanisms, including: avoiding stranded costs by preserving the integrity of the franchised service territory; accelerated depreciation to reduce the burden of uneconomic costs; revaluation of assets or adjustment of returns during transition; adjustment of rates; imposing access fees on new suppliers; tax-based solutions; requiring writeoffs; creating and funding a stranded cost recovery fund; encouraging end-use efficiency through research and development; and not providing guarantee of service to a departing customer who may wish to return.

${ }^{110}$ FERC proposed to establish firm point-to-point transmission charges by applying the fixed-charge methodology. Form 1 data are used to develop the cost relationship between fixed transmission costs and transmission plant investment (a fixed-charge rate). The unit charge is calculated by dividing plant investment by capability and by multiplying the result by the fixed-charge rate. FERC also suggested an alternative method of computing these charges and sought comments on which method it should finally adopt for finalizing point-to-point computations. Network transmission charges are derived by using the load ratio method. Details of the derivation of charges for other services are also provided in the NOPR.

${ }^{111}$ Point-to-point transmission service is the reservation and/or transmission of energy (either on a firm or non-firm basis) from point of receipt to point of delivery, including, where necessary, ancillary service by the transmission provider. Network transmission service (also called network integration transmission service) allows a transmission customer to integrate, economically dispatch, and regulate its current and planned network resources to serve its net work load in a manner comparable to that in which the transmission provider utilizes its transmission system to serve its native load customers. These definitions are derived from FERC's Mega-NOPR.
} 
Information Networks (RINs). ${ }^{112}$ According to the Commission, the establishment of RINs is expected to ensure that potential purchasers of transmission services have access to information to obtain open access transmission services on a nondiscriminatory basis from the public utilities. This goal will require each public utility to create a RIN operating under industry-wide standards no later than the date of issuance of the final rules on open access transmission. In issuing the RIN notice, the Commission sought comments on the type of information to be made available and on the nature of standards to be incorporated. ${ }^{113}$

\section{The Final Rules: Order Nos. 888 and 889}

On April 24, 1996, the Commission issued two separate but interrelated final rules and a Notice of Proposed Rulemaking pursuant to its authority under Sections 205 and 206 of the FPA. ${ }^{114}$ The first rule, Order No. 888, addresses the twin issues of open access and stranded costs. The second rule, Order 889 , requires utilities to establish electronic systems to share information about available transmission capacity. This rule is known as the Open Access Same-Time Information System (OASIS) rule. In addition, the Commission issued a new Notice of Proposed Rulemaking called the Capacity Reservation Open Access Transmission Tariffs (CRT) NOPR. This NOPR aims to establish a new system for the utilities to use in reserving capacity on their own and others' transmission systems. ${ }^{115}$

Taken together, the above provisions are expected to "remove impediments to competition in wholesale trade and to bring more efficient, lower cost power to the Nation's electricity customers. ${ }^{116}$ The Commission argues that these rules will alleviate undue discrimination in transmission services in interstate commerce and will provide an orderly and fair transition to competitive bulk power markets without impairing the continued reliability of the industry. ${ }^{117}$

The type of discrimination addressed by the rules is, namely, that a utility must provide service that is comparable to the service that it provides itself. Potential quantitative benefits from these provisions are estimated to be in the range of $\$ 3.8$ billion to $\$ 5.4$ billion per year of cost savings. ${ }^{118}$ Nonquantitative benefits include better utilization of existing assets and institutions, new market mechanisms, technical innovations, and reduced rate distortion. ${ }^{119}$

\section{Open Access Final Rule}

Elimination of monopoly power over transmission is the primary objective of the above rules. To achieve this objective, the Commission requires all public utilities that own, control, or operate facilities used for transmitting electric energy in interstate commerce to:

- File open access nondiscriminatory transmission tariffs containing minimum terms and conditions

- Take transmission service (including ancillary services) for their own new wholesale sales and purchases of electricity under open access tariffs

- Develop and maintain a same-time information system that will give existing and potential users the same access to transmission information that the public utility enjoys

- Separate the transmission from generating and marketing functions and communications.

\footnotetext{
${ }^{112}$ In its final ruling, the Commission supported the concept of RINs in another format and renamed it the "Open Access Same-Time Information System Rule" or OASIS.

${ }^{113}$ The Commission subsequently issued its Notice of Proposed Rulemaking on Real-Time Information Networks and Standards of Conduct, Docket No. RM95-9-000 (December 13, 1995). Under the proposal, each public utility (or its agent) that owns and/or controls facilities used for the transmission of electric energy in interstate commerce would be required to create and/or participate in a RIN that would provide wholesale customers and potential wholesale transmission customers with electronically provided information on available transmission capacity, prices, and other relevant information to obtain open access nondiscriminatory transmission service.

114 The Commission provided an unprecedented level of detail in more than a thousand pages of documentation with respect to Order Nos. 888 and 889.

${ }^{115}$ Federal Energy Regulatory Commission, Notice of Proposed Rulemaking: The Capacity Reservation Open Access Transmission Tariff, Docket No. RM96-11-000 (April 24, 1996).

${ }^{116}$ Federal Energy Regulatory Commission, Order No. 888, Final Rule issued on April 24, 1996 (Docket Nos. RM95-8-000, Promoting Wholesale Competition Through Open Access Nondiscriminatory Transmission Services by Public Utilities, and RM94-7-001, Recovery of Stranded Costs by Public Utilities and Transmitting Utilities), p. 1.

${ }^{117}$ Ibid., p. 11.

118 Annual estimated cost reductions or savings depend on, among other things, the assumptions regarding coal and natural gas prices. Refer to Federal Energy Regulatory Commission, Final Environmental Impact Statement, FERC/EIS-0096 (Washington, DC, April 1996).

${ }^{119}$ The Commission expects that these additional savings (which have not been quantified) will be passed on to retail customers in retail rates which would continue to be based on cost of service.
} 
Based on the above directives, public utilities will file a single open access tariff offering both network load-based service and point-to-point contract-based service. ${ }^{120}$ The final rule does not prescribe rates for network, point-topoint, or ancillary services. Instead, public utilities may charge current rates or apply for new transmission rates.

The open access tariffs were due to be filed by July 9 , 1996. As of that date, of the 166 utilities under the Commission's jurisdiction, 165 had filed open access tariffs or waivers. Of these 165 utilities, 144 filed tariffs, 21 filed waiver requests, and 13 filed both tariffs and waiver requests seeking exemption from certain parts of the rule. ${ }^{121}$

It should be noted that special provisions cover power pools, public utility holding companies, and bilateral coordination arrangements. Because FERC's primary intent is to eliminate undue discrimination in transmission access, a restructuring (or modification) of the existing tariff structures is mandated. As an example, the term "coordination" applies to a variety of wholesale power sales agreements within the industry that include interchange, interconnection, pooling, and other agreements. These coordination arrangements and the agreements governing them vary widely, ranging from simple bilateral arrangements to complex tight power pools. ${ }^{122}$ FERC determined that certain wholesale agreements and arrangements must be modified to ensure that necessary transmission services for such arrangements and agreements are taken under open access transmission tariffs and thus that such arrangements and agreements are not unduly discriminatory. FERC allowed additional time until December 31, 1996, for transactions under these arrangements to comply with the open access requirements. ${ }^{123}$

Abrogation of existing requirement contracts is not envisaged; however, the utilities or customers can seek modification or termination of existing contracts on a case- by-case basis. Modifications may also be necessary with respect to coordination arrangements and contracts with the intent of removing their discriminatory content. Guidance regarding the voluntary formation of independent system operators is also provided.

Mention may also be made of some other relevant issues:

- Corporate restructuring is not mandated, even though it is recognized that voluntary reorganization may take place.

- Since not all interstate transmission facilities fall within the Commission's jurisdiction, reciprocity provisions are included to preclude the possibility of non-open access utilities taking unfair advantage of open access utilities. ${ }^{124}$

- The Commission's review of market-based rates would require that the seller (including its affiliates) not have market power in generation and transmission and not control barriers to entry.

- The Commission issued a new NOPR on capacity reservation tariffs (CRTs) as an alternative means of remedying discrimination. ${ }^{125}$

- The Commission reaffirmed its jurisdiction over the rates, terms, and conditions of unbundled retail transmission in interstate commerce by public utilities. ${ }^{126}$ The Commission, however, did not wish to encroach on the legitimate concerns of State regulatory authorities in the area of restructuring or in the way electricity is sold and regulated at the retail level.

- The Commission will permit utilities to seek recovery of stranded costs pertaining to wholesale

${ }^{120}$ All public utilities subject to the FPA's jurisdiction and their customers are affected by these rules, which go into effect 60 days after being published in the Federal Register. Reciprocity is required for those receiving service under the new tariff.

${ }_{121}$ Public Power Weekly (July 29, 1996).

${ }^{122}$ Four categories of arrangements and accompanying agreements recognized in are: tight power pools, loose power pools, public utility holding company arrangements and bilateral coordination arrangements.

${ }^{123}$ Public Power Weekly (July 29, 1996).

124 The reciprocity provisions would be applicable to all customers, including municipally owned utilities and rural electric cooperatives that own, control, or operate interstate transmission facilities. Apprehensions by nonpublic utilities that they may be denied transmission service (based on claims by public utilities that their services are unsatisfactory) were taken into account by the Commission in developing a voluntary "safe harbor" procedure. This procedure requires nonpublic utilities to submit their transmission tariffs to obtain the Commission's ruling with respect to their meeting the comparability criteria. Nonpublic utilities that are members of a regional transmission group (RTG) can meet the comparability standard criteria through the RTG.

${ }^{125}$ Federal Energy Regulatory Commission, Notice of Proposed Rulemaking: Capacity Reservation Open Access Transmission Tariffs, Docket No. RM96-11-000 (April 24, 1996). This NOPR requests comment on whether there are certain disadvantages inherent in offering transmission service on both a network and point-to-point service. Underlying this request is the belief that a single-service open access tariff could possibly better accommodate competitive changes in the industry and ensure fairness and nondiscrimination.

${ }_{126}$ Various components of retail transmission costs are currently aggregated into a single, composite tariff. The generic term "unbundling" implies that the individual cost components of retail transmission are disaggregated and shown separately. 
requirements contracts from departing customers by direct assignment. Utilities may seek recovery of stranded costs caused by retail wheeling through the Commission only in cases where the State regulatory authority does not have authority under State law to address stranded costs when retail wheeling is required.

\section{Environmental Considerations}

Open transmission access may open opportunities for purchases of power from some power plants that would emit more nitrogen oxides $\left(\mathrm{NO}_{x}\right)$ than would the sources they would displace. Since $\mathrm{NO}_{\mathrm{x}}$ emissions are related to ground-level ozone formation with its associated adverse health and environmental effects, the Commission analyzed the possible environmental impacts of its Final Rule with specific reference to an increase in $\mathrm{NO}_{\mathrm{x}}$ emissions. ${ }^{127}$

In its Final Environmental Impact Statement (FEIS), FERC maintained that requiring the utilities to open their electricity transmission facilities would have only minimal impacts on the environment during the next 15 years. Overall, the FEIS provides the following results:

- The relative prices of natural gas and coal have a larger impact on $\mathrm{NO}_{x}$ emissions than any impacts from the proposed rule
- The proposed rule is projected to have only slight impacts on $\mathrm{NO}_{\mathrm{x}}$ emissions, and the impacts are as likely to be beneficial as to be harmful

- Even a substantial increase in transmission capacity would change emissions estimates by very small amounts

- In the worst-case scenario, emission impacts are negligible or nonexistent, with increases in the range of 2 to 3 percent by the year 2005

- Mitigation of $\mathrm{NO}_{x}$ emissions and ozone formation should be addressed comprehensively (within the existing legal framework) rather than on a piecemeal basis by the Commission.

The above conclusions prompted the Commission not to initiate any interim mitigation measures that might undermine the basic goals of its open access rule. Acknowledging its inability to initiate and administer a national environmental program, the Commission nevertheless expressed its intent to assist development of long-term programs designed to reduce $\mathrm{NO}_{x}$ emissions in close collaboration with the Environmental Protection Agency (EPA) and the Ozone Transport Assessment Group (OTAG) ${ }^{128}$ A summary of the major provisions of Order 888 is provided in the following insets.

\begin{tabular}{l}
\hline Major Provisions of FERC Orde \\
\hline Stranded Cost Requirement \\
The recovery of legitimate and verifiable stranded costs shall be allowed. \\
Direct assignment of stranded costs computed on a revenues lost basis \\
is the appropriate method for recovery \\
\hline Wholesale Stranded Cost Definition \\
Any legitimate, prudent, and verifiable cost incurred by a utility to provide \\
service to a wholesale requirements customer, a retail customer, or a \\
newly created wholesale power sales customer that subsequently \\
becomes, in whole or in part, an unbundled wholesale transmission \\
services customer of such utility.
\end{tabular}

Stranded Cost Recovery for Retall-Turned-Wholesale Customers

FERC shall be the primary forum for addressing recovery of stranded costs caused by retail-turned-wholesale customers. A utility may seek recovery of stranded costs associated with a retail customer who becomes a legitimate wholesale transmission customer as a result of access to wholesale transmission through rates for wholesale transmission services to that customer. An evidentiary demonstration must be made. Any recovery permitted by a State will be deducted from the FERC-determined stranded cost recovery.

\footnotetext{
${ }^{127}$ Federal Energy Regulatory Commission, Final Environmental Impact Statement, FERC/EIS-0096 (Washington, DC, April 1996).

${ }^{128}$ Several other issues raised by the commenters with respect to the EIS were deemed to be outside its scope. These included State jurisdictional issues, site-specific issues, and stranded cost issues.
} 


\begin{tabular}{|c|c|}
\hline \multicolumn{2}{|c|}{ Major Provisions of FERC Order $\mathbf{8 8 8}$ on Stranded Costs (Continued) } \\
\hline $\begin{array}{l}\text { Contract Definitions } \\
\text { A new contract is one executed after July } 11,1994, \text { or extended or } \\
\text { renegotiated to be effective after July } 11,1994 \text {. } \\
\text { An existing contract is one executed on or before July } 11,1994 \text {. }\end{array}$ & $\begin{array}{l}\text { Recovery of Retall Stranded Costs } \\
\text { Although both FERC and States have the legal authority to address retall } \\
\text { stranded costs, FERC determined that States should have primary } \\
\text { jurisdiction over the recovery of stranded costs arising from retail } \\
\text { wheeling. A utility may seek recovery of stranded costs through } \\
\text { transmission rates from customers who obtain retail wheeling only if the } \\
\text { State regulator has no authority under State law to address stranded } \\
\text { costs at the time retail wheeling is required. A similar evidentiary } \\
\text { demonstration must be made. }\end{array}$ \\
\hline $\begin{array}{l}\text { Stranded Cost Recover Under New Contracts } \\
\text { A public utility may not seek recovery of stranded costs under new } \\
\text { contracts except in accordance with an exit fee or other explicit provision } \\
\text { contained in the contract. Prior notice to FERC of temination of new } \\
\text { power sales contracts is no longer required. } \\
\text { A public utillty may not seek recovery of stranded costs under new } \\
\text { contracts except in accordance with an exit fee or other explicit provision } \\
\text { contained in the contract. Prior notice to FERC of termination of new } \\
\text { power sales contracts is no longer required. }\end{array}$ & \multirow{2}{*}{$\begin{array}{l}\text { Evidentiary Demonstration } \\
\text { A utility seeking recovery of stranded costs must demonstrate that it } \\
\text { incurred the costs on behalf of the wholesale requirements customer } \\
\text { or retail customer based on a reasonable expectation that the utility } \\
\text { would continue to serve the customer. } \\
\text { If the existing contract contains a notice provision, there will be a } \\
\text { rebuttable presumption that the utility had no reasonable expectation of } \\
\text { continuing to serve the customer beyond the term of the notice } \\
\text { provision. } \\
\text { Whether State law awards exclusive service territories and imposes a } \\
\text { mandatory obligation to serve would be among the factors to be } \\
\text { considered in determining whether the reasonable expectation test is } \\
\text { met in a particular case involving either a retail or retail-turned- } \\
\text { wholesale customer. }\end{array}$} \\
\hline \multirow{2}{*}{$\begin{array}{l}\text { Stranded Cost Recovery Under Existing Contracts } \\
\text { A public utility may seek recovery of stranded costs under existing } \\
\text { contracts that do not contain exit fees or other explicit stranded cost } \\
\text { provisions as follows: }\end{array}$} & \\
\hline & Determination of Recoverable Wholesale Stranded Costs \\
\hline \multirow{5}{*}{$\begin{array}{l}\text { The parties may negotiate a stranded cost amendment and file } \\
\text { it with FERC. } \\
\text { - Either party may seek FERC approval of a stranded cost } \\
\text { amendment under Section } 205 \text { or } 206 \text { any time prior to the } \\
\text { expiration of the contract. } \\
\text { - The public utility or transmitting utility may file a proposal to re- } \\
\text { cover stranded costs through Section } 205 \text { or Section } 211-212 \\
\text { rates for wholesale transmission services to the customer. } \\
\text { FERC will reject stranded cost amendments to existing contracts that } \\
\text { include explicit provisions for payment of stranded costs or exit fees. }\end{array}$} & $\begin{array}{l}\text { Determination of recoverable stranded costs shall be based on a } \\
\text { "revenues lost" approach. The utility shall calculate a customer's } \\
\text { stranded cost liability using the following formula: }\end{array}$ \\
\hline & $\begin{array}{l}\text { SCO }=(\text { RSE }- \text { CMVE }) \times L \text { where } \\
\text { SCO }=\text { Present value of stranded cost obligation }\end{array}$ \\
\hline & $\begin{array}{l}\text { RSE = Average annual revenues from the departing generation customer } \\
\text { over the } 3 \text { years prior to the customer's departure (with the variable cost } \\
\text { component of revenues clearly identified), less the average transmission- } \\
\text { related revenues that the host utility would have recovered from the } \\
\text { departing generation customer over the same } 3 \text { years under its new } \\
\text { wholesale transmission tariff. }\end{array}$ \\
\hline & Advanced Notice of Stranded Cost Calculation \\
\hline & $\begin{array}{l}\text { Prior to the termination date of an existing contract, a customer may } \\
\text { request the utility to calculate the customer's stranded costs exposure } \\
\text { using the prescribed formula. The utility would have } 30 \text { days or a } \\
\text { mutually agreed upon period to respond. If the customer believes that } \\
\text { the utility has falled to establish reasonable expectation, the customer } \\
\text { has } 30 \text { days to respond so to the utility. If the parties cannot reach a } \\
\text { mutually agreeable charge within a reasonable time period, the } \\
\text { customer can file a complaint with FERC or contest the charge when the } \\
\text { utility files it. }\end{array}$ \\
\hline & \\
\hline
\end{tabular}




\section{Major Provisions of FERC Order 888 on Open Access}

\section{Functional Unbundling}

A utility's uses of its own transmission system for the purpose of engaging in wholesale sales and purchases must be separated from other activities. Corporate unbundling is not required.

- Utilities must take transmission services (including ancillary services) under the same tariff of general applicability as do others.

- Utilities must state separate rates for wholesale generation, transmission, and ancillary services.

- Utilites must rely upon the same electronlc information network that its transmission customers rely upon to obtain transmission information.

\section{Nondiscriminatory Open Access Tarlff Requirement}

By July 9,1996 , jurisdictional utillites that own or control transmission must have filed a single open access tariff that offers both network, loadbased services and point-to-point, contract-based services, including ancillary services, to eliglble customers comparable to the service they provide themselves at the wholesale level. The rule provides a single pro forma tariff that sets forth minimum conditions for both network and point-to-point services and nonprice terms and conditions for providing those services and ancillary services.

\section{Pools and Holding Companies}

Jurisdictional utilities who are members of tight or loose power pools must fle either an individual pro forma tariff or a joint pool-wide pro forma tariff by July 9, 1996. They are not required to take service for pool transactions under that tariff, but are required to file a joint pool-wide tariff no later than December 31, 1996, and begin to take service under that tariff for all pool transactions by that same date. By that date, they must also restructure their ongoing operations and open membership to nonutilities.

Public utility holding companies not subject to tight or loose pool requirements are required to file a single system-wide pro forma tariff permitting transmission service across the entire holding company by July $9,1996$.

All bilateral economy energy coordination contracts executed before the effective date of this rule must be modified to require unbundling of any economy energy transaction occurring after December 31, 1996.

\section{Customer Eligibility}

Any entity engaged in wholesale purchases or sales of energy or retail purchases is an eligible customer.

Source: Adapted from "FERC Finalizes Electric Industry Restructuring Rule," Public Utility Topics, No. 96-2 (Philadelphia, PA: Coopers \& Lybrand, L.L.P.), p. 4.

\section{Reciprocity}

Transmission customers of jurisdictional utilities who take service under the open access tariff and who own, control, or operate transmission facilities must, in turn, provide open access service to the transmitting utility. This includes municipally owned entities and RUS cooperatives.

\section{Services To Be Provided}

A public utility must offer transmission services that it is reasonably capable of providing, not just those services that it currently provides to itself and others.

Six ancillary services must be included in the open access tariff:

1. Scheduling, system control, and dispatch

2. Reactive supply and voltage control from generation sources

3. Regulation and frequency response

4. Energy imbalance

5. Operating reserve-spinning reserve

6. Operating reserve-supplemental reserve

The transmission customer must purchase the first two services from the transmission provider.

\section{Pricing}

The rule does not prescribe rates for network, point-to-point, or ancillary services. Instead, utilities may charge current rates or apply for new transmission rates. Utilities can propose to recover opportunity costs and expansion costs. Crediting for customers' transmission facilities will be permitted on a case-by-case basis. Proposed pricing must conform with FERC's Transmission Pricing Policy Statement.

\section{Contract Reform}

The rule does not void any existing requirements contracts. The functional unbundling requirement applies only to transmission services under new requirements contracts, new coordination contracts, and new transactions under existing coordination contracts.

Parties to requirements contracts executed on or before July 11,1994 , may seek modification of such contracts on a case-by-case basis, even if they contain a Mobile-Sierra clause. FERC, however, does not take contract modification lightly and parties seeking to modify contracts will have a heavy burden to demonstrate the need for it.

\section{Market-Based Rates}

Utilities seeking market-based rates for sale of electricity at wholesale from new capacity are no longer required to demonstrate lack of market power in generation. New capacity is that for which construction has commenced on or after the effective date of this rule. For existing generation, FERC will continue its case-by-case approach that includes an analysis of generation market power in first and second tier markets. 
1. The ISO's governance should be structured in a fair and nondiscriminatory manner.

2. An ISO and its employees should have no financial interest in the economic performance of any power market participant. An ISO should adopt and enforce strict conflict-of-interest standards.

3. An ISO should provide open access to the transmission system and all services under its control at non-pancaked rates pursuant to a single, unbundled, grid-wide tariff that applies to all eligible users.

4. An ISO should have the primary responsibility in ensuring short-term reliability of grid operations. Its role should be well defined and comply with applicable standards set by the North American Electric Reliability Council and the regional reliability council.

5. An ISO should have control over the operation of interconnected transmission facilities within its region.

6. An ISO should identify constraints on the system and be able to take operational actions to relieve those constraints within the trading rules established by the governing body. These rules should promote efficient trading.

7. An ISO should have appropriate incentives for efficient management and administration and should procure the services needed for such management and administration in an open competitive market.

8. An ISO's transmission and ancillary services pricing policies should promote the efficient use of, and investment in, generation, transmission, and consumption. An ISO or an RTG of which an ISO is a member should conduct such studies as may be necessary to identify operational problems or appropriate expansions.

9. An ISO should make transmission system information publicly available on a timely basis via OASIS.

10. An ISO should develop mechanisms to coordinate with neighboring control areas.

11. An ISO should establish an Alternative Dispute Resolution (ADR) process to resolve disputes in the first instance.

Source: Adapted from "FERC Finalizes Electric Industry Restructuring Rule," Public Utility Topics, No. 96-2 (Philadelphia, PA: Coopers \& Lybrand, L.L.P.), p. 9.

\section{Information Systems, Standards of Conduct, and Independent System Operators (ISOs)}

The second rule, Order No. 889, also known as the Open Access Same-Time Information System (OASIS) rule (formerly called Real-Time Information Networks or RINs) requires utilities to share information available on the electronic system and prescribes the Standards of Conduct. ${ }^{129}$ This rule was issued after a review of the comments filed with the Commission in response to its notice of proposed rulemaking (also known as the RIN NOPR) on December 13, 1995. ${ }^{130}$
Under this rule, each public utility (or its agent) that owns, controls, or operates transmission facilities will create or participate in an OASIS that will provide open access transmission customers (current and potential) with electronic information about transmission capacity, prices, and other information necessary to obtain open access nondiscriminatory transmission service. Accordingly, the rule will require the public utilities to obtain information about the transmission system for their own wholesale power transactions in the same way as their competitors do via the OASIS. The rule is thus expected to ensure that transmission owners (and their affiliates) do not have an unfair advantage in transmission usage to sell power. ${ }^{131}$

129 This rule was issued in tandem with the Commission's Open Access Final Rule (Order 888). Refer to Federal Energy Regulatory Commission, Open Access Same-Time Information System (formerly Real-Time Information Networks) and Standards of Conduct, Docket No. RM95-9-000 (April 24, 1996).

${ }^{130}$ The Commission relied on the efforts of two industry-led groups in formulating the rule on some of the issues. The first group (called the What Group) led by the North American Reliability Council (NERC) assisted in the preparation of a report on what information should be included in the RIN. The second group (called the How Group) led by the Electric Power Research Institute (EPRI) facilitated the formulation of how to implement the suggestions of the What Group.

${ }^{131}$ The basic OASIS required by this rule is expected to be in place and operational by November 1,1996 . Its development will continue in the next phase for development of a fully functional OASIS. 
The rule also establishes standards of conduct to ensure that a public utility's employees engaged in transmission system operations function independently of those employees engaged in wholesale purchases and sales of electric energy in interstate commerce. ${ }^{132}$ Specifics with respect to various standards and protocols to ensure that the OASIS system presents information in a consistent and uniform manner (subject to the accommodation of additional changes as may become necessary in the future) have also been detailed.

The Commission noted that many utilities plan to go beyond the concept of functional unbundling (requiring the separation of generation and transmission) and turn over transmission to an independent system operator (ISO) ${ }^{133}$ While not mandating the formation of ISOs, the Commission encouraged their creation.

Recognizing that the ISOs will fall under the Commission's jurisdiction, specific guidelines for their creation have been stipulated. Of these, the most critical is the requirement that the management and control of ISOs be completely independent of generation owners so as to ensure compliance with the Commission's nondiscriminatory transmission tariff requirements. Other guidelines deal with responsibilities of ISOs that include management, pricing issues, and related matters.

\section{The Capacity Reservation Open Access Transmission Tariff NOPR}

The Open Access Final Rule requires each public utility that owns, operates, or controls facilities used for the transmission of electric energy in interstate commerce to file an open access nondiscriminatory tariff and to take transmission service for their own wholesale sales and purchases under this tariff. The Final Rule makes two different types of transmission service available in one tariff: (1) network service, which is based on use (i.e., load), and (2) point-to-point service, which is based on transmission capacity reservations. Fixed costs of transmission systems are allocated among network customers on the basis of use (i.e., loads) and among point-to-point customers on the basis of their reservations (i.e., contract demands).
The above provisions of the Open Access Final Rule tariff are designed to remedy discrimination in interstate transmission service. Some stakeholders, however, expressed the view that the operation of the Final Rule in concert with the provisions of the OASIS renders the system too inflexible to accommodate industry innovations. It may also be necessary to place all transmission customers on an equal footing.

In view of the foregoing, FERC issued a Notice of Proposed Rulemaking (NOPR) in conjunction with the issuance of the Open Access Final Rule. ${ }^{134}$ This NOPR, known as the "Capacity Reservation Open Access Tariff," proposes to replace the Open Access Final Rule tariff with a single service open access capacity reservation tariff that would accommodate both network and point-to-point needs. ${ }^{135}$ Transmission products and services should be provided on an open access, comparable basis. With a view to ensure comparability, transmission service should be nominated and reserved on a nondiscriminatory basis.

The basic service concept in the CRT is that all firm transmission service be reserved and that all reserved service be firm service. Reservations of capacity thus permit the customer to receive up to a specific amount of power on the grid at specific "points of receipt" and to deliver up to a specific amount of power from the grid at specified "points of delivery." A customer with a capacity reservation would be entitled to use the reservation either to deliver the power or receive it.

FERC maintains that adoption of this procedure will provide a better alternative to accommodate competitive changes occurring in the industry. Other arguments in support of CRT include:

- Under a CRT approach, the capacity requirements of each customer, including those of the provider, would be clearly known, permitting all customers to be treated comparably. In order to ensure comparability, transactions could thus become transparent

- The CRT allows all jurisdictional customers to be placed on the same footing, in that all customers not only reserve capacity but pay for the capacity reserved.

\footnotetext{
${ }^{132}$ Compliance with this rule should have been achieved by November 1, 1996. The FERC, however, granted the industry's request for an extension of the starting date for the OASIS. It will now start on January 3, 1997.

${ }^{133}$ An ISO is an operator of a designated set of transmission facilities. The discussion of the ISOs is part of a wider discussion that includes such related subjects as coordination arrangements, power pools, tight power pools, loose power pools, public utility holding companies, and bilateral coordination arrangements.

${ }^{134}$ See Federal Energy Regulatory Commission, Notice of Proposed Rulemaking: Capacity Reservation Open Access Transmission Tariffs, Docket No. RM96-11-000 (April 24, 1996).

${ }^{135}$ The NOPR stipulates that each utility subject to the open access rule file a CRT no later than December 31, 1997.
} 
- The CRT permits a basis for a regional flow-based pricing mechanism considered superior to the contractpath pricing in the Final Rule. ${ }^{136}$

- The CRT approach may facilitate transmission planning for all users.

- Since load-based network service will be difficult to sell, the need to monitor the secondary market as a risk management tool will be greatly minimized. ${ }^{137}$ Growth of secondary market transactions is accordingly contained.

FERC's CRT proposals are deemed to be conceptually compatible with a competitive bulk power market. ${ }^{138}$ However, there are many details that need to be spelled out. The North American Electric Reliability Council (NERC) recently stated that the CRT NOPR, as it is currently written, lacks sufficient details and more discussion is needed to develop a well-defined model that would make sense commercially and economically. ${ }^{139}$ To meet this objective, NERC stated that technical principles that are unique to the operation of interconnected electric networks should be addressed in tandem with commercial market needs to define a transmission service model that will be commercially workable and operationally practical.

\section{The Post-888 Reactions}

Observers point out that there were few surprises in the Commission's landmark ruling designed to propel the industry toward a more competitive, nondiscriminatory open access wholesale market. The final rules on open access, stranded cost recovery, and electronic transmission information networks remain within the framework outlined in the March 29, 1995, Mega-NOPR. ${ }^{140}$ However, the Commission's provisions on many issues have not been universally acceptable to all. Some of the issues that are causing controversy are as follows:

- FERC's action to permit full recovery of stranded costs from departing wholesale customers is perhaps the most contentious issue. Support as well as opposition to this move comes from multiple sources. Customers who cannot get lower electricity prices immediately consider FERC's action as delaying the benefits of competition. Those whose assets are in jeopardy consider that the move enables them to remain in business and become competitive.

- Many municipals, cooperatives, and foreign utilities find the reciprocity provision for public utilities intrusive and unacceptable. ${ }^{141}$ The Nebraska Public Power District (NPPD) told the Commission that the State had no investor-owned utilities and viewed the reciprocity requirement as unconstitutional. ${ }^{142}$ Application of the reciprocity requirement, as envisaged in Order 888, infringes on State sovereignty. According to NPPD, there is no compelling reason to require reciprocity, and voluntary participation will eventually emerge without FERC's imposition. ${ }^{143}$

- State regulatory authorities disagree with the extension of FERC's jurisdiction over unbundled transmission services provided to retail trade customers and the recovery of stranded costs when retail trade customers become wholesale customers. According to the National Association of Regulatory Utility Commissioners (NARUC), FERC's assertion of authority over the rates, terms, and conditions

\footnotetext{
${ }^{136}$ The contract path method, it is contended, does not correspond to the physical flows on the network, implying that the market view and uses of the network may be inconsistent with the physical view of the system needed for reliability.

${ }^{137}$ The NOPR lists a number of potential changes in the power industry, including independent system operators, regional transmission groups, regional power exchanges, generation divestiture, distribution company spinoffs, unified regional transmission ownership, regional transmission tariffs, megawatt-mile transmission pricing, and congestion transmission pricing

${ }^{138}$ See S.M. Harvey, W.W. Hogan, and S.L. Pope, "Transmission Capacity Reservations Implemented Through a Spot Market with Transmission Congestion Contracts," Electricity Joumal (November 1996), pp. 42-55.

${ }^{139}$ Comments of the North American Electric Reliability Council submitted to the Federal Energy Regulatory Commission in the matter of Notice of Proposed Rulemaking and Request for Comments on Capacity Reservation Open Access Transmission Tariffs, Docket No. RM96-11-000 (October 21, 1996).

${ }^{140}$ Electric Utility Weekly (April 29, 1996).

${ }^{141}$ Order 888 lists some of the differences between investor-owned and publicly owned utilities. Some of these arise from the use of tax-exempt financing, restrictions on rate-setting methods, and statutory restrictions on services that publicly owned utilities can provide. Rural cooperatives also differ significantly from investor-owned utilities.

${ }_{142}$ The Nebraska Public Power District filed application for a rehearing on this subject with the Commission on May 24, 1996.

${ }^{143}$ Refer to Energy Report (June 3, 1996).
} 
of unbundled retail transmission services is based on a flawed understanding of the roles established for State and Federal regulators. ${ }^{144}$

- Environmentalists and lawmakers in the Northeast raised the possibility that increased emissions from coal-fired plants in the Midwest may result in a deterioration of the environment, particularly in the Northeast, and petitioned the U.S. Environmental Protection Agency (EPA) to refer the matter to the White House Council on Environmental Quality (CEQ) for review. ${ }^{145}$ On May 13, 1996, the EPA did refer the matter to the CEQ but did not ask that implementation of Order 888 be stayed. EPA also expressed its intent to work with the Ozone Transport Assessment Group (OTAG) to devise a regional capand-trade program for $\mathrm{NO}_{x}$ emissions from power plants. ${ }^{146}$ In the meantime, FERC initiated a Notice of Inquiry to solicit comments on the air pollution impacts of Order 888. The Department of Energy has also been directed by the White House to monitor emission levels in the future.

- There is apprehension that the attempt to usher in competition and lower prices may be impeded if the process results in the creation of "mega-mergers" with market power incompatible with competitive norms. For example, if one or a group of suppliers acquires the capability (by increasing market power) in a way that results in the restriction of output, the resulting prices may no longer be competitive in wholesale or retail markets.

- FERC has initiated a reevaluation of its merger policy with a Notice of Inquiry (NOI) on whether its criteria and policies for evaluating electric utility mergers need to be revised in view of the changes confronting the industry. ${ }^{147}$

\section{Reliability Issues}

Reliability in the United States is covered by government and industry. The interstate trade sections of the Federal Power Act assigned the oversight responsibility first to the Federal Power Commission (since known as the FERC) and later to the Department of Energy. Industry participation is handled by NERC. ${ }^{148}$ To lay the groundwork for a general discussion of the issues concerning reliability, a workable definition of the term is necessary. ${ }^{149}$ In its naive version, reliability implies that power will be available when it is needed. Stated another way, the term reliability connotes how well your utility succeeds in giving you (or the customers) the quality or the continuity of service desired. ${ }^{150}$ Most discussion concerning reliability concepts, however, revolves around the bulk power electric system and the degree to which its performance affects the continuity of power supply to the customers. ${ }^{151}$

\footnotetext{
${ }^{144}$ Refer to testimony by the National Association of Regulatory Utility Commissioners before the U.S. Senate Committee on Energy and Natural Resources on Competitive Changes in the Electric Power Industry: Orders 888 and 889 of the Federal Energy Regulatory Commission (Washington, DC, July 11, 1996).

${ }_{145}^{14}$ Gas Daily (May 14, 1996).

${ }^{146}$ OTAG is the 37-State group formed to find a regional solution to the pollution transport problem.

${ }^{147}$ Federal Energy Regulatory Commission, Notice of Inquiry: Inquiry Concerning Commission's Merger Policy Under the Federal Power Act, Docket No. RM96-6-000 (Washington, DC, January 31, 1996).

${ }_{148}$ Because of the November 9,1965 , blackout affecting the northeastern United States, the electric utility industry was given an opportunity to either improve the operations of the electrical systems and promote reliability or face mandatory obligations from regulatory and legal actions. The electric utility industry formed a voluntary organization that handled self-regulation through peer reviews. That organization has evolved into the North American Electric Reliability Council (NERC). NERC consists of nine Regional Reliability Councils and one Affiliate whose members account for virtually all the electricity supplied in the United States, Canada, and a portion of Baja California Norte, Mexico. The members of these Councils are from all segments of the electricity supply industry-investor-owned, Federal, rural electric cooperative, State/municipal, and provincial utilities, independent power producers, and power marketers.

${ }^{149}$ For an excellent discussion of the reliability concepts, refer to North American Electric Reliability Council, Reliability Concepts (Princeton, NJ, February 1985).

${ }^{150}$ A more specific definition of reliability, "in a bulk power system, is the degree to which the performance of the elements of that system results in power being delivered to consumers within accepted standards and in the amount desired. The degree of reliability may be measured by the frequency, duration, and magnitude of adverse effects on consumer service." The two basic functional aspects of the bulk power system are adequacy and security. Adequacy is the ability of the bulk power electric system to supply the aggregate electric power and energy requirements of the consumers at all times, taking into account scheduled and unscheduled outages of system components. Security is the ability of the bulk power system to withstand sudden disturbances such as electric short circuits or an unanticipated loss of system components." North American Electric Reliability Council, Reliability Concepts (Princeton, NJ, February 1985).

${ }^{151}$ Bulk power electric system is a term describing the aggregate of electric generating plants, transmission lines, and appurtenant equipment. The term may refer to those facilities within one electric utility, or within a group of utilities in which the transmission lines are interconnected. North American Electric Reliability Council, Reliability Concepts (Princeton, NJ, February 1985).
} 
It is generally presumed that the deregulation of the industry and the introduction of open access would not impact the requirement to maintain reliable electric systems. However, with challenges confronting the utilities in a competitive environment, there is uncertainty as to whether compliance with the venerable "rules of the road" for electric interconnection and planning will be maintained as it has been in the past. ${ }^{152}$

Potential changes in market behavior contribute to reliability concerns. Take, for example, the price differential between the Northwest and Southwest, which is capable of triggering huge shifts in energy that cannot be supported by the existing transmission system. It is pointed out that in the past utilities operated transmission and generation capacity according to preventive operating procedures to guard against system disturbances, including running sufficient generating capacity to provide operating reserves in excess of demand and limiting power transfers on the system to be able to handle a single contingency. Today, much of that excess is being sold on the market. As a result, the system is taxed to the maximum in an effort to make profits. Unless the new entrants can also envision the culture of reliability, problems are likely to occur. ${ }^{153}$

A somewhat similar view has been expressed by the Electric Power Research Institute (EPRI). EPRI states that as utilities increase maximum utilization of their transmission and distribution assets, efficiency may be enhanced but stress on power grids increases. As higher loads and more power transfers take place, electric systems are being operated nearer and nearer their physical limits. Serious new stability problems are cropping up, problems that have long-distance impacts not predicted by conventional stability analysis tools. In this context, the division of vertically integrated utilities reduces the ability of any one organization to manage global power flow. ${ }^{154}$

As a result of the western electric power outage of July 2, 1996, the Department of Energy (DOE) provided a report to the President with respect to the causes, responses, and preventability of the incident. While conceding that the present institutional framework (to promote reliability) remains essentially sound, "it will continue to work in the future provided [emphasis added] it can adapt the current structure to the new competitive environment facing the industry." ${ }^{\prime 155}$ For this purpose, DOE will recommend changes and process improvements to address reliability challenges as the restructuring process unfolds. DOE will also create a task force to define a research agenda to address issues pertaining to ensuring reliability.

Industry changes will thus cause modifications to be made which would ensure system reliability. Within this changing environment, it is not known who will be responsible for future planning and construction for the electrical transmission system (additions and upgrades), either as a unified approach or through an operational entity. No group in the electric power industry has stepped forward to take responsibility for building new lines and supplying equipment to support out-of-State electrical system usage. Unbundled electric utilities will not consider projects outside their service territories or competitive markets. However, how system reliability will function in a period of downsizing and cost cutting remains to be seen.

\section{Conclusions}

Events in the electric utility industry are moving faster than anticipated. The issuance of Orders 888 and 889 sets in motion a chain of events that will take time to unfold and establish. While the intent to deregulate generation has been established and barriers to competition have been lowered, some stakeholders uphold the view that the transition to a full-fledged competitive trade in electricity will be a slow process. Maintaining system reliability may perhaps be the most critical determinant in the spread of competition. The spirit of prevailing cooperation on this and other related issues will benefit the industry in a rapidly changing atmosphere.

\section{Role of States in Promoting Competition}

Title VII of EPACT included amendments to the FPA and PUHCA that were designed to encourage increased reliance on competition and market mechanisms in the

\footnotetext{
152 The "rules of the road" refer to a set of policies, standards, criteria, principles, and guides established by NERC for electric interconnection operation and planning. NERC remains confident about the future even though it is conceded that different mechanisms may be needed to ensure the necessary operational discipline needed for reliability. Refer to North American Electric Reliability Council, 1995 Annual Report (Princeton, NJ, 1996).

${ }^{153}$ Based on a report in Electric Utility Week (August 18, 1996).

${ }^{154}$ P. Haase, "Breakthrough in Stability Analysis," EPRI Journal (July/August 1996), pp. 25-30.

${ }^{155}$ U.S. Department of Energy, The Electric Power Outages in the Western United States, July 2-3, 1996 (Washington, DC, August 1996).
} 
electric utility industry. ${ }^{156}$ Many of the provisions affected State utility commissions and their regulated utilities. ${ }^{157}$ Faced with the most sweeping legislation affecting the industry, the State utility commissions commenced evaluating the adequacy and compatibility of their regulatory framework to meet the challenges likely to confront the industry in the future.

In the years following enactment of EPACT, there has been a surge of activity at State utility commissions to examine various issues with respect to the electric utility industry. Critical among them has been a wide range of activities designed to promote industry competition at the retail level and to complement the wholesale wheeling and stranded cost initiatives of the Federal Energy Regulatory Commission. ${ }^{158}$

\section{Regulatory Initiatives ${ }^{159}$}

Not all State commissions have moved with the same zeal, even though most of them have under consideration the merits and implications of competition, deregulation, and electric utility industry restructuring. States with high electricity rates, such as California and those in the Northeast, had compelling reasons to promote competition in the hope of making lower rates available to their consumers in general.

As an example, the California Public Utility Commission (CPUC) directed an examination of the comprehensive set of regulatory programs in order to explore alternatives to the current regulatory approach based on conditions and trends identified in its Decision No. 92-09-088 of September $1992 .{ }^{160}$ This directive resulted in the submission of a staff report-generally known as the "Yellow Book" - to the CPUC in February 1993. ${ }^{161}$

The "Yellow Book" study concluded that the State should reform its regulatory program, including a redefinition of the prevailing regulatory compact, and offered strategies to address shortcomings of its regulatory framework.
Based on a comprehensive reexamination of the electric utility industry in the State and the regulatory policy under which the industry functioned, the CPUC opened rulemaking and investigative proceedings to consider its proposed restructuring policies in early $1994 .{ }^{162}$ These initiatives, popularly known as the "Blue Book" proposals, outlined a strategy to replace the traditional costof-service regulatory framework with alternatives that focused on utility performance and, where possible, the discipline of the market.

Other States that commenced early consideration of the issues include New York, Michigan, Massachusetts, and Wisconsin. Since then, most other States have also begun addressing issues associated with promoting industry competition. As of June 30, 1996, 44 States and the District of Columbia (more than 88 percent of the Nation's regulatory commissions) had started restructuring activities in one form or another. Commissions may undertake a range of activities resulting in concrete plans for implementation, or their activities may be purely exploratory with potential for developing plans for retail wheeling in the future. For some commissions, the process may be purely informational, with action, if any, to be taken at some future date.

Among the 45 jurisdictions that have initiated restructuring activities, 24 have formal proceedings in progress, 18 are conducting informal inquiry or study, and only 3 States have made "final" decisions concerning the scope of competition and the type of market structure to go with it in the future.

State utility commissions that have initiated formal proceedings (as of June 30, 1996) are Arizona, Connecticut, Delaware, District of Columbia, Idaho, Iowa, Louisiana, Maine, Massachusetts, Michigan, Minnesota, Montana, Nevada, New Hampshire, New Jersey, New Mexico, Ohio, Oklahoma, Pennsylvania, Texas, Utah, Vermont, Virginia, and Washington.

\footnotetext{
${ }^{156}$ See Appendix F.

${ }^{157}$ National Regulatory Research Institute, A White Paper on the Energy Policy Act of 1992: An Overview for State Commissions of New PURPA Statutory Standards (Columbus, OH, April 1993).

158 Title VII of EPACT enabled FERC to direct an electric utility to provide "wholesale wheeling." No such provisions were made with respect to retail wheeling.

${ }_{159}$ Information contained in this section draws on the research undertaken by Dr. Jeff Fang of the National Renewable Energy Laboratory with funding provided by the Energy Information Administration.

${ }_{160}$ California Public Utility Commission, Decision 92-09-088, W4, 32, "Order Instituting Investigation on the Commission's Own Motion To Implement the Biennial Resource Plan Update Following the California Energy Commission's Seventh Electricity Report," (September 16, 1992).

${ }^{161}$ Refer to California Public Utility Commission, California's Electric Services Industry: Perspectives on the Past, Strategies for the Future (San Francisco, CA, February 1993).

${ }^{162}$ California Public Utility Commission, "Order Instituting Rulemaking on the Commission's Proposed Policies Governing Restructuring California's Electric Services Industry and Reforming Regulation and Order Instituting Investigation on the Commission's Proposed Policies Governing Restructuring of California's Electric Services Industry and Reforming Regulation," Docket Nos. R.94-04-031 and I.94-04-032 (April 20, 1994).
} 
Other State commissions that have initiated informal inquiry or study (as of June 30,1996) include Alaska, Colorado, Georgia, Hawaii, Illinois, Indiana, Kansas, Kentucky, Maryland, Mississippi, Missouri, North Carolina, North Dakota, Oregon, Rhode Island, South Carolina, West Virginia, and Wyoming. State commissions in California, New York, and Wisconsin had taken final decisions by the end of June 1996.

Five States (Illinois, Massachusetts, Michigan, New Hampshire, and New York) have already instituted retail wheeling experiments or pilot programs. However, Michigan's program has been overtaken by events. ${ }^{163}$ The experiences of these States will be closely watched by those interested in initiating similar activities.

Only a small minority of States, such as Idaho and Nebraska, have taken the view that the main tenets of EPACT (as pertaining to promoting competition) are difficult for them to implement. The Idaho Public Utilities Commission (IPUC), for example, notes that it is not its role to actively attempt to bring about deregulation of the industry. The IPUC expressed the concern that rates in Idaho could go up, and, at the same time, deregulation could result in the diminution of the quality of service enjoyed by the ratepayers in the State. ${ }^{164}$ The Nebraska Public Power District (NPPD) maintains that applying reciprocity requirement provisions of FERC Order 888 violates Nebraska's law and its constitutional rights. ${ }^{165}$

Finally, no regulatory activity had been reported in six States: Alabama, Arkansas, Florida, Nebraska, South Dakota, and Tennessee (as of June 30, 1996).

\section{Legislative Activities}

All State utility commissions typically enjoy broad regulatory authority to ensure that electric utilities in their jurisdiction provide fair, just, and reasonable electricity rates to their customers. In addition, State commissions are also empowered to regulate various other aspects of power generation, transmission, and distribution at the State level. However, not all commissions may be endowed with the necessary legal authority to manage an evolving competitive market structure. Accordingly, legislation in some States may be designed primarily to grant the utility regulatory agency the authority to address the restructuring issues or to consider alternative ratemaking processes (incentive- or performance-based regulation). Elsewhere, State legislators may evince a serious interest in finding out how the State should respond to new competitive pressures emerging in the electric industry. ${ }^{166}$ Exploratory activities may also be promoted at the behest of the State legislators in an effort to gain additional insights. ${ }^{167}$ In some cases, legislative actions may become necessary to adopt decisions recommended by the commission(s) for implementation.

As of June 30, 1996, 25 States were addressing restructuring-related activities, while the other 25 States and the District of Columbia had no such activity. ${ }^{168}$ Of the 25 States with legislative activities, 12 have enacted some legislation: Alabama, Arizona, Connecticut, Delaware, Kansas, Maine, Mississippi, New Hampshire, New Jersey, Oregon, Texas, and Virginia. Legislation is under consideration in 6 States: California, Massachusetts, New York,

${ }^{163}$ The Michigan Public Service Commission (MPSC) specified that the program will be started when the utilities plan to solicit new capacity. Neither Detroit Edison Company nor Consumers Power Company has requirements for capacity in the near term. To complicate matters, the two utilities challenged the authority of the MPSC to order retail wheeling. As a result, the MPSC has opened a proceeding to address the recommendations of the Michigan Jobs Commission concerning restructuring. Subsequent regulatory action in Michigan was initiated at the specific request of the State's executive branch. Governor John Engler of Michigan released (in January 1996), a "blueprint" for electric and gas utility reform based in part on reports submitted by the Michigan Jobs Commission. The MPSC has not yet concluded its study based on the recommended "blueprint."

${ }^{164}$ Idaho Public Service Commission's Order No. 26555, Case No. GNR-E-96-1, "In the Matter of the Commission's Investigating into Changes Occurring in the Electric Industry" (August 16, 1996).

${ }^{165}$ Note that Nebraska has no privately owned electric utilities. All generation, transmission, and distribution service in Nebraska is provided by public entities, municipalities, and cooperatives whose governing boards are responsible to, and serve at the voting pleasure of, rate-paying Nebraska citizens.

${ }^{166}$ On July 3, 1995, Legislative Resolve Resolve to Require a Study of Retail Competition in the Electric Industry became Maine Law. This legislation directed the Maine Public Utilities Commission (MPUC) to begin a study and submit its findings to the Legislature by January 1,1997 . The study must develop at least two plans for an orderly transition to a competitive market and must identify the plan the MPUC believes to be in Maine's best interests. The MPUC, in response to this legislation, issued its draft report on July 19, 1996.

${ }^{167}$ The New Hampshire legislature, for example, passed legislation in June 1995 directing the New Hampshire Public Utility Commission (NHPUC) to establish a pilot program to examine the implications of retail competition. In its order establishing preliminary guidelines for a retail competition pilot program, the NHPUC noted that the program was not necessarily a step toward wide-scale competition but was rather a way to examine the implications of an obstacle to a competitive retail market at a time when supply shortages are not a concern. Subsequent legislation (HB-1392), enacted in May 1996, directs the NHPUC to undertake a generic proceeding to develop and establish a final order establishing a statewide electric utility restructuring plan no later than February 28, 1997.

${ }^{168}$ As of June 30, 1996, there was no legislative activity in Alaska, Arkansas, Colorado, Florida, Georgia, Hawaii, Idaho, Indiana, Kentucky, Louisiana, Maryland, Michigan, Missouri, Montana, North Carolina, North Dakota, South Carolina, South Dakota, Tennessee, Utah, Vermont, Washington, West Virginia, Wisconsin, Wyoming, or the District of Columbia. 
Ohio, Pennsylvania, and Rhode Island. ${ }^{169}$ The 7 Statesundertaking studies are Illinois, Iowa, Minnesota, Nebraska, Nevada, New Mexico, and Oklahoma. Table 5 shows the status of electric industry restructuring, by State, as of June 30, 1996.

\section{Issues Under Consideration}

A wide range of issues are under consideration by the States. Critical among them are the following:

- Industry structure, including functional unbundling and/or divestiture of generation assets

- Creation of independent system operators and power exchanges

- Estimation and recovery of strandable costs

- Evaluation of the current "obligation to serve" requirement in a deregulated environment
- Other remaining issues, including environmental considerations and support for public policy programs (such as demand-side management, assistance to low income households, support for green power, and others)

- Timetable for implementation.

The above issues are complex and do not easily lend themselves to solutions that are acceptable to all stakeholders. Most State proceedings are, therefore, involved in an ongoing dialogue with all stakeholders to reach a possible consensus on issues involved. Even where decisions have been made, it is open to parties to take up the matter at a judicial level. It is, therefore, likely that deregulation of the electric utility industry will take time to be completed and to be effective.

${ }^{169}$ The California legislature enacted a landmark electric deregulation bill (AB 1890) on August 31 and September 1, 1996. The bill was signed into law by Governor Pete Wilson on September 23, 1996. 
Table 5. Status of Electric Industry Restructuring by State, as of June 30, 1996

\begin{tabular}{|c|c|c|c|c|c|c|c|c|c|c|}
\hline \multirow[b]{2}{*}{ State } & \multicolumn{2}{|c|}{ Overall Status } & \multirow{2}{*}{$\begin{array}{c}\begin{array}{c}\text { Type of } \\
\text { Competition }\end{array} \\
\end{array}$} & \multirow{2}{*}{$\begin{array}{c}\text { New } \\
\text { Institutions }\end{array}$} & \multirow{2}{*}{$\begin{array}{c}\text { Generation } \\
\text { Assets }\end{array}$} & \multirow{2}{*}{$\begin{array}{l}\text { Transition } \\
\text { Costs/ } \\
\text { Stranded } \\
\text { Investment }\end{array}$} & \multirow{2}{*}{$\begin{array}{c}\text { System } \\
\text { Benefits } \\
\text { Charge }\end{array}$} & \multirow{2}{*}{$\begin{array}{c}\text { Renewable } \\
\text { Energy }\end{array}$} & \multirow{2}{*}{$\begin{array}{l}\text { Performance } \\
\text { Based } \\
\text { Ratemaking }\end{array}$} & \multirow[b]{2}{*}{ Notes and Comments } \\
\hline & Regulatory & Legislative & & & & & & & & \\
\hline Alabama & No activity & Bill enacted & & & & $\begin{array}{l}\text { Authority } \\
\text { to consider } \\
\text { granted }\end{array}$ & & & & $\begin{array}{l}\text { SB } 306, \text { enacted on } 5 / 6 / 96 \text {, } \\
\text { authorizes the Cornmission or } \\
\text { Circuit Court to review private } \\
\text { contracts to determine whether } \\
\text { existing customers should } \\
\text { reimburse the utility for any } \\
\text { stranded cost associated with } \\
\text { the transfer of electrical } \\
\text { services. }\end{array}$ \\
\hline Alaska & Informal inquiry & No activity & & & & & & & & \\
\hline Arizona & $\begin{array}{l}\text { Formal proceed- } \\
\text { ing in progress }\end{array}$ & Bill enacted & & & & & & & & $\begin{array}{l}\text { HB } 2504 \text {, enacted on } 4 / 23 / 96 \text {, } \\
\text { established Joint Study } \\
\text { Committee on restructuring, } \\
\text { which will report to the } \\
\text { legislature by } 12 / 31 / 97 \text {. }\end{array}$ \\
\hline Arkansas & No activity & No activity & & & & & & & & \\
\hline California & $\begin{array}{l}\text { Final decision, } \\
12 / 20 / 95\end{array}$ & $\begin{array}{l}\text { Under consid- } \\
\text { eration }\end{array}$ & $\begin{array}{l}\text { Wholesale and } \\
\text { retail (r) }\end{array}$ & $\begin{array}{l}\text { ISO, Power } \\
\text { Exchange (r) }\end{array}$ & $\begin{array}{l}\text { Functional } \\
\text { unbuindling, } \\
\text { Incentives for } \\
\text { voluntary } \\
\text { divestiture (r) }\end{array}$ & $\begin{array}{l}\text { Recovery } \\
\text { allowed (r) }\end{array}$ & Yes (r) & $\begin{array}{l}\text { Renewables } \\
\text { portfolio } \\
\text { standard (r) }\end{array}$ & Yes (r) & \\
\hline Colorado & Informal inquiry & No activity & & & & & & & & \\
\hline Connecticut & $\begin{array}{l}\text { Formal proceed- } \\
\text { ing in progress }\end{array}$ & Bill enacted & & & & & & & $\begin{array}{l}\text { Authority } \\
\text { granted by } \\
\text { HB 5045, } \\
5 / 2 / 96\end{array}$ & $\begin{array}{l}\text { The DPUC has issued a final } \\
\text { report to the legislative task } \\
\text { force on restructuring.Task force } \\
\text { report due } 12 / 31 / 96 \text {. HB } 5405 \text {, } \\
\text { enacted on } 5 / 2 / 96 \text {, authorizes } \\
\text { the DPUC to approve } \\
\text { performance-based incentives. }\end{array}$ \\
\hline Delaware & $\begin{array}{l}\text { Formal proceed- } \\
\text { ing in progress }\end{array}$ & Bill enacted & $\begin{array}{l}\text { Wholesale } \\
\text { and retail (r) }\end{array}$ & & & $\begin{array}{l}\text { Recovery } \\
\text { allowed (r) }\end{array}$ & & & & $\begin{array}{l}\text { HB } 69 \text {, enacted on } 6 / 12 / 95, \\
\text { authorizes the PUC to } \\
\text { deregulate the electrical utility } \\
\text { industry. The PUC has formal } \\
\text { proceedings underway to study } \\
\text { how the industry should be } \\
\text { deregulated. }\end{array}$ \\
\hline
\end{tabular}


Table 5. Status of Electric Industry Restructuring by State, as of June 30, 1996 (Continued)

\begin{tabular}{|c|c|c|c|c|c|c|c|c|c|c|}
\hline \multirow[b]{2}{*}{ State } & \multicolumn{2}{|c|}{ Overall Status } & \multirow{2}{*}{$\begin{array}{c}\text { Type of } \\
\text { Competition }\end{array}$} & \multirow{2}{*}{$\begin{array}{c}\text { New } \\
\text { Institutions }\end{array}$} & \multirow{2}{*}{$\begin{array}{l}\text { Generation } \\
\text { Assets }\end{array}$} & \multirow{2}{*}{$\begin{array}{l}\text { Transition } \\
\text { Costs/ } \\
\text { Stranded } \\
\text { Investment }\end{array}$} & \multirow{2}{*}{$\begin{array}{l}\text { System } \\
\text { Benefits } \\
\text { Charge }\end{array}$} & \multirow{2}{*}{$\begin{array}{c}\text { Renewable } \\
\text { Energy }\end{array}$} & \multirow{2}{*}{$\begin{array}{l}\text { Performance } \\
\text { Based } \\
\text { Ratemaking }\end{array}$} & \multirow[b]{2}{*}{ Notes and Comments } \\
\hline & Regulatory & Legislative & & & & & & & & \\
\hline $\begin{array}{l}\text { District of } \\
\text { Columbia }\end{array}$ & $\begin{array}{l}\text { Formal proceed- } \\
\text { ing in progress }\end{array}$ & No activity & & & & & & & & $\begin{array}{l}\text { PSC Docket No. } 945 \text { initiated } \\
\text { investigation into the } \\
\text { restructuring of electrical utility } \\
\text { industry. Also considering } \\
\text { merger of PEPCO and BG\&E. } \\
\text { The PSC is currently deciding } \\
\text { which issues should be } \\
\text { considered in each case. }\end{array}$ \\
\hline Florida & No activity & No activity & & & & & & & & $\begin{array}{l}\text { Generic docket on special } \\
\text { contracts for large customers } \\
\text { opened on } 7 / 1 / 96 \text {. }\end{array}$ \\
\hline Georgia & Informal inquiry & No activity & & & & & & & & \\
\hline Hawaii & Informal inquiry & No activity & & & & & & & & \\
\hline Idaho & $\begin{array}{l}\text { Formal proceed- } \\
\text { ing in progress }\end{array}$ & No activity & & & & & & & & \\
\hline Illinois & $\begin{array}{l}\text { Informal inquiry, } \\
\text { retail wheeling } \\
\text { pilots }\end{array}$ & Study & & & & & & & $\begin{array}{l}\text { Authority } \\
\text { granted by } \\
\text { SB } 232 \\
7 / 21 / 95\end{array}$ & $\begin{array}{l}\text { SJR } 21 \text {, signed by Governer on } \\
7 / 21 / 95 \text {, initiated a study of } \\
\text { electric restructuring, to be } \\
\text { completed by } 11 / 8 / 96 \text {. Pilots for } \\
\text { CILCO and Illinois Power, } \\
\text { orders in } 94-0435,95-0494 \text {. }\end{array}$ \\
\hline Indiana & Informal inquiry & No activity & & & & & & & $\begin{array}{l}\text { Authority } \\
\text { granted by } \\
\text { SB } 637 \\
4 / 26 / 95\end{array}$ & $\begin{array}{l}\text { SB } 637, \text { signed by Governor on } \\
4 / 26 / 95, \text { gave commission } \\
\text { increased authority to consider } \\
\text { alternative rates and } \\
\text { mechanisms, including } \\
\text { performance-based ratemaking. }\end{array}$ \\
\hline lowa & $\begin{array}{l}\text { Formal proceed- } \\
\text { ing in progress }\end{array}$ & Study & & & & & & & & $\begin{array}{l}\text { Legislative Interim Study } \\
\text { Committee examined renewable } \\
\text { incentives. }\end{array}$ \\
\hline Kansas & Informal inquiry & Bill enacted & & & & & & & & $\begin{array}{l}\text { HB } 2600 \text {, enacted on } 4 / 10 / 96 \text {, } \\
\text { established a retail wheeling } \\
\text { task force. }\end{array}$ \\
\hline Kentucky & Informal inquiry & No activity & & & & & & & & \\
\hline
\end{tabular}


Table 5. Status of Electric Industry Restructuring by State, as of June 30, 1996 (Continued)

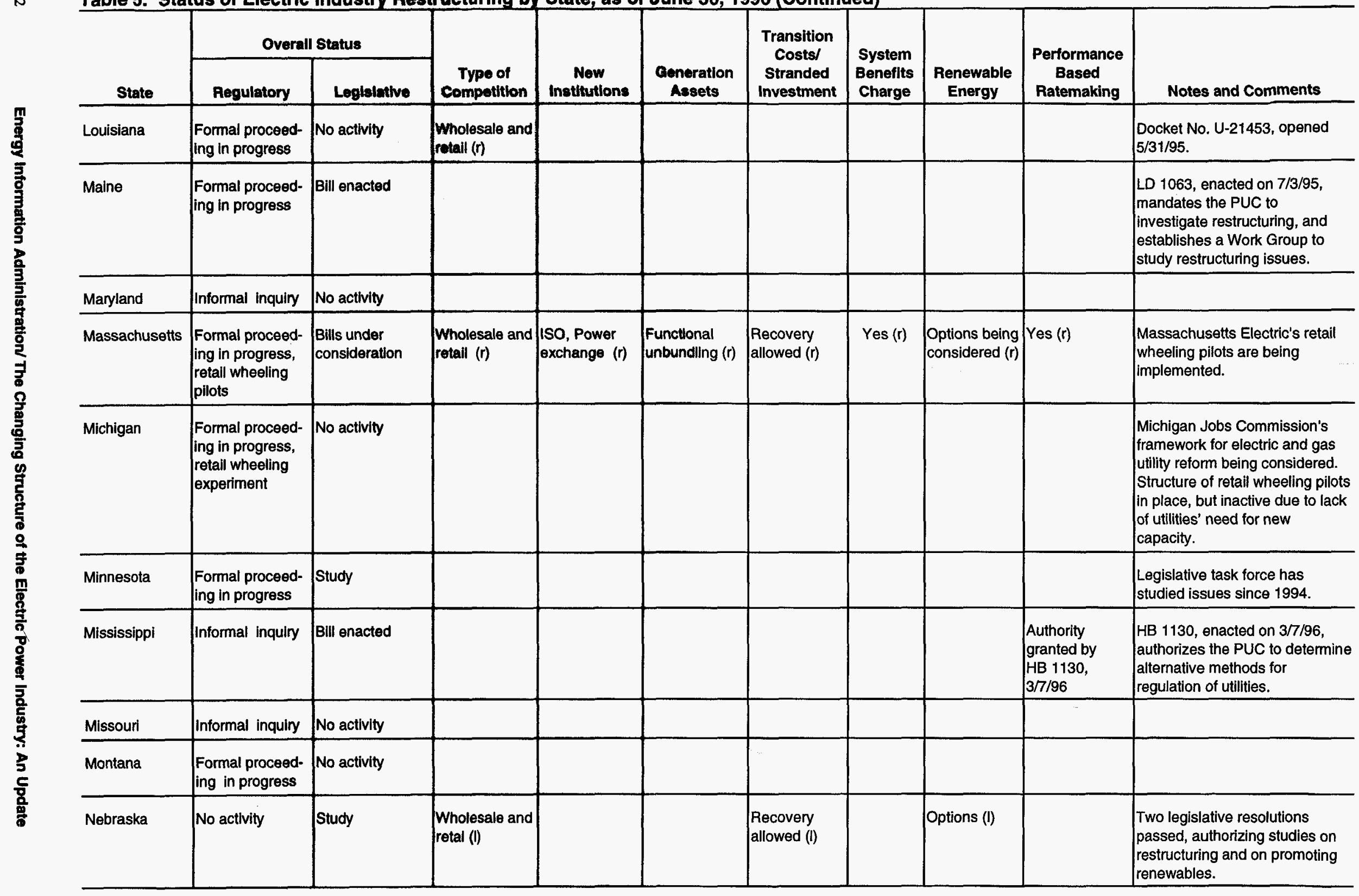


Table 5. Status of Electric Industry Restructuring by State, as of June 30, 1996 (Continued)

\begin{tabular}{|c|c|c|c|c|c|c|c|c|c|c|}
\hline \multirow[b]{2}{*}{ State } & \multicolumn{2}{|c|}{ Overall Status } & \multirow[b]{2}{*}{$\begin{array}{c}\text { Type of } \\
\text { Competition }\end{array}$} & \multirow[b]{2}{*}{$\begin{array}{c}\text { New } \\
\text { Institutions }\end{array}$} & \multirow[b]{2}{*}{$\begin{array}{l}\text { Generation } \\
\text { Assets }\end{array}$} & \multirow{2}{*}{$\begin{array}{l}\text { Transition } \\
\text { Costs/ } \\
\text { Stranded } \\
\text { Investment }\end{array}$} & \multirow{2}{*}{$\begin{array}{l}\text { System } \\
\text { Benefits } \\
\text { Charge }\end{array}$} & \multirow[b]{2}{*}{$\begin{array}{c}\text { Renewable } \\
\text { Energy }\end{array}$} & \multirow{2}{*}{$\begin{array}{c}\text { Performance } \\
\text { Based } \\
\text { Ratemaking }\end{array}$} & \multirow[b]{2}{*}{ Notes and Comments } \\
\hline & Regulatory & Legislative & & & & & & & & \\
\hline Nevada & $\begin{array}{l}\text { Formal proceed- } \\
\text { ing in progress }\end{array}$ & Study & & & & & & $\begin{array}{l}\text { Optional } \\
\text { green pricing: } \\
\text { SB } 503 \text {, } \\
6 / 29 / 95 . \\
\text { Other acts } \\
\text { promoting } \\
\text { renewables: } \\
\text { SB } 267 \\
6 / 12 / 95 ; \text { SB } \\
504,6 / 29 / 95 ; \\
\text { SCR } 11 \\
\end{array}$ & & $\begin{array}{l}\text { Under ACR } 49 \text {, an interim study } \\
\text { on restructuring was conducted. } \\
\text { A parallel study by the PUC also } \\
\text { examined the issues conceming } \\
\text { retail competition. }\end{array}$ \\
\hline $\begin{array}{l}\text { New } \\
\text { Hampshire }\end{array}$ & $\begin{array}{l}\text { Formal proceed- } \\
\text { ing in progress, } \\
\text { retail wheeling } \\
\text { pilot }\end{array}$ & Bill enacted & $\begin{array}{l}\text { Wholesale and } \\
\text { retail (r) }\end{array}$ & & $\begin{array}{l}\text { Functional } \\
\text { unbundling (r) }\end{array}$ & $\begin{array}{l}\text { Recovery } \\
\text { allowed }(r)\end{array}$ & & & & $\begin{array}{l}\text { HB } 1392 \text {, enacted on } 5 / 21 / 96 \text {, } \\
\text { requires implementation of retail } \\
\text { wheeling by } 1 / 1 / 98 \text {. On } 2 / 28 / 96, \\
\text { the PUC issued Docket } 95-250 \\
\text { to implement retail competition } \\
\text { pilot program, which covered } \\
\text { issues relating to type of } \\
\text { competition, functional } \\
\text { unbundling, and strandable } \\
\text { costs. }\end{array}$ \\
\hline New Jersey & $\begin{array}{l}\text { Formal proceed- } \\
\text { ing in progress }\end{array}$ & Bill enacted & $\begin{array}{l}\text { Wholesale and } \\
\text { retail }(r)\end{array}$ & ISO (r) & $\begin{array}{l}\text { Functional } \\
\text { unbundling, } \\
\text { divestiture } \\
\text { required (r) }\end{array}$ & & & & $\begin{array}{l}\text { Authority } \\
\text { granted by } S \\
1940,7 / 20 / 96\end{array}$ & $\begin{array}{l}\text { S } 1940, \text { enacted on } 7 / 20 / 96, \\
\text { allows utilities to provide rate } \\
\text { discounts to industrial and } \\
\text { commercial customers. Also } \\
\text { gives PUB authority to approve } \\
\text { alternative ratemaking } \\
\text { regulations. Various issues are } \\
\text { considered in Docket No. } \\
\text { EX94120585Y, issued on } \\
6 / 27 / 96, \text { including type of } \\
\text { competition, ISO, functional } \\
\text { unbundling, and required } \\
\text { divestiture. }\end{array}$ \\
\hline New Mexico & $\begin{array}{l}\text { Formal proceed- } \\
\text { ing in progress }\end{array}$ & Study & $\begin{array}{l}\text { Wholesale and } \\
\text { retail }(r)\end{array}$ & & & & & & & $\begin{array}{l}\text { Senate Joint Memoranda } 42 \text { and } \\
43 \text { authorized study of } \\
\text { restructuring. }\end{array}$ \\
\hline New York & $\begin{array}{l}\text { Final decision } \\
5 / 16 / 96, \text { retail } \\
\text { wheeling pilots }\end{array}$ & $\begin{array}{l}\text { Bills under } \\
\text { consideration }\end{array}$ & $\begin{array}{l}\text { Wholesale and } \\
\text { retail }(r)\end{array}$ & $\begin{array}{l}\text { ISO, Power } \\
\text { Exchange (r) }\end{array}$ & $\begin{array}{l}\text { Functional } \\
\text { unbundling (r) }\end{array}$ & $\begin{array}{l}\text { Recovery } \\
\text { allowed (r) }\end{array}$ & Yes (r) & $\begin{array}{l}\text { No explicit } \\
\text { treatment } \\
(r)\end{array}$ & Yes (r) & $\begin{array}{l}\text { Niagara Mohawk Power, } \\
\text { Orange \& Rockland Utilities are } \\
\text { planning retail wheeling pilots. }\end{array}$ \\
\hline North Carolina & Informal inquiry & No activity & & & & & & & & \\
\hline
\end{tabular}


Table 5. Status of Electric Industry Restructuring by State, as of June 30, 1996 (Continued)

\begin{tabular}{|c|c|c|c|c|c|c|c|c|c|c|}
\hline \multirow[b]{2}{*}{ State } & \multicolumn{2}{|c|}{ Overall Status } & \multirow{2}{*}{$\begin{array}{c}\text { Type of } \\
\text { Competition }\end{array}$} & \multirow{2}{*}{$\begin{array}{c}\text { New } \\
\text { Institutions }\end{array}$} & \multirow{2}{*}{$\begin{array}{l}\text { Generation } \\
\text { Assets }\end{array}$} & \multirow{2}{*}{$\begin{array}{c}\text { Transition } \\
\text { Costs/ } \\
\text { Stranded } \\
\text { Investment } \\
\end{array}$} & \multirow{2}{*}{$\begin{array}{l}\text { System } \\
\text { Benefits } \\
\text { Charge }\end{array}$} & \multirow{2}{*}{$\begin{array}{l}\text { Renewable } \\
\text { Energy }\end{array}$} & \multirow{2}{*}{$\begin{array}{c}\text { Performance } \\
\text { Based } \\
\text { Ratemaking } \\
\end{array}$} & \multirow[b]{2}{*}{ Notes and Comments } \\
\hline & Regulatory & Legislative & & & & & & & & \\
\hline North Dakota & Informal inquiry & No activity & & & & & & & & \\
\hline Ohio & $\begin{array}{l}\text { Formal proceed- } \\
\text { ing in progress }\end{array}$ & $\begin{array}{l}\text { Bills under } \\
\text { consideration }\end{array}$ & $\begin{array}{l}\text { Wholesale and } \\
\text { retail } \\
\text { (l) }\end{array}$ & & $\begin{array}{l}\text { Functional } \\
\text { unbundling (I) }\end{array}$ & $\begin{array}{l}\text { Recovery } \\
\text { allowed (l) }\end{array}$ & & & & $\begin{array}{l}\text { HB 653, which is under } \\
\text { consideration, addresses the } \\
\text { issues of retail wheeling, } \\
\text { functional unbundling, and } \\
\text { strandable costs. }\end{array}$ \\
\hline Oklahoma & $\begin{array}{l}\text { Formal proceed- } \\
\text { ing in progress }\end{array}$ & Study & & & & & & & & $\begin{array}{l}\text { SJR } 29 \text {, signed by the Governor } \\
\text { on } 6 / 5 / 95 \text {, created a task force } \\
\text { to study restructuring issues. } \\
\text { SJR } 371 \text { extended it to } \\
12 / 31 / 96 \text {. }\end{array}$ \\
\hline Oregon & Informal inquiry & Bill enacted & & & & & & & $\begin{array}{l}\text { Authority } \\
\text { granted by HB } \\
2846,7 / 19 / 95\end{array}$ & $\begin{array}{l}\text { HB } 2846 \text {, enacted on } 7 / 19 / 95 \text {, } \\
\text { allows the PUC to approve } \\
\text { alternative forms of rate } \\
\text { regulation. }\end{array}$ \\
\hline Pennsylvania & $\begin{array}{l}\text { Formal proceed- } \\
\text { ing in progress }\end{array}$ & $\begin{array}{l}\text { Bills under } \\
\text { consideration }\end{array}$ & & & & & & & & $\begin{array}{l}\text { HB } 2557 \text { and SB } 1475 \text { are both } \\
\text { under consideration. Both } \\
\text { address how to set up and } \\
\text { introduce competition into the } \\
\text { electric utility industry. }\end{array}$ \\
\hline Rhode Island & Informal inquiry & $\begin{array}{l}\text { Bills under } \\
\text { consideration }\end{array}$ & & & & & & & & $\begin{array}{l}\text { Final report of PUC } \\
\text { Restructuring Collaborative } \\
\text { issued on } 2 / 22 / 94, \text { after which } \\
\text { the Collaborative was } \\
\text { suspended. HB } 8124 \text { passed } \\
\text { the House, but stalled in Senate. }\end{array}$ \\
\hline South Carolina & Informal inquiry & No activity & & & & & & & & \\
\hline South Dakota & No activity & No activity & & & & & & & & \\
\hline Tennessee & No activity & No activity & & & & & & & & \\
\hline Texas & $\begin{array}{l}\text { Formal proceed- } \\
\text { ing in progress }\end{array}$ & Bill enacted & $\begin{array}{l}\text { Wholesale } \\
\text { only (I) }\end{array}$ & & & & & & & $\begin{array}{l}\mathrm{SB} 373 \text {, effectiive } 6 / 16 / 95 \\
\text { deregulated the wholesale } \\
\text { market. }\end{array}$ \\
\hline Utah & $\begin{array}{l}\text { Formal proceed- } \\
\text { ing in progress }\end{array}$ & No activity & & & & & & & & \\
\hline
\end{tabular}


Table 5. Status of Electric Industry Restructuring by State, as of June 30, 1996 (Continued)

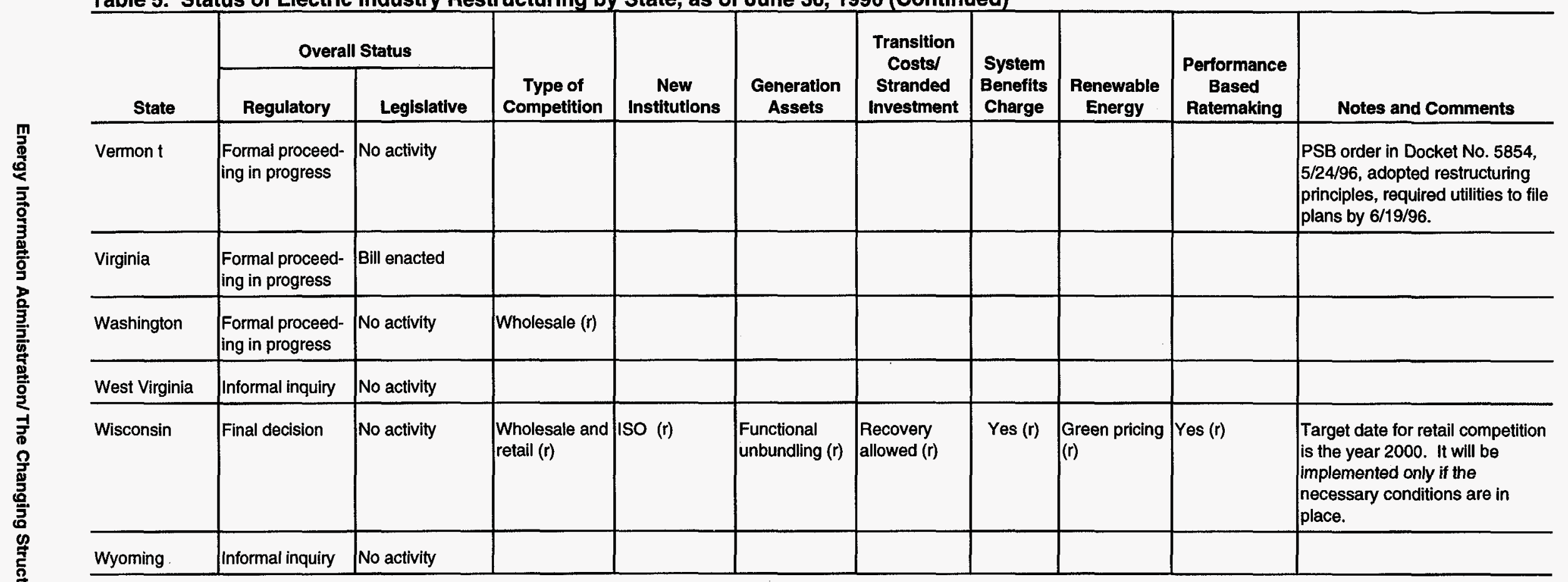

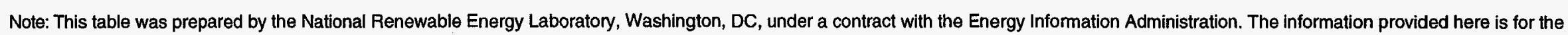
period ended June 30, 1996

ISO = Independent system operator

$(r)=$ Regulatory

(l) = Legislative.

Source: National Renewable Energy Laboratory. 


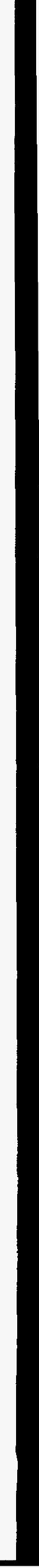




\section{Stranded Costs in Electricity Deregulation: An Overview of Potential Mitigation Strategies ${ }^{10}$}

Recovery of stranded costs is perhaps the most contentious issue confronting regulators in promoting competition in the electric power industry. Accordingly, this chapter looks at the possible options that can be used to mitigate the level of stranded costs confronting utilities. The potential impacts of implementing selected mitigation strategies are also evaluated in the case of a hypothetical utility using a financial model.

In its Order 888, the Federal Energy Regulatory Commission (FERC) reaffirmed its preliminary determination "that the recovery of legitimate, prudent and verifiable stranded costs should be allowed." ${ }^{\prime 171}$ FERC's directive is grounded in the belief that the recovery of stranded costs is "critical to the successful transition of the electric industry to a competitive, open access environment."172 For this purpose, direct assignment of costs to departing customers was selected as the appropriate method for recovery of stranded costs.

Stranded costs can arise in both wholesale and retail transactions. Because retail competition is driven by State policies, mitigation strategies may be of relevance to them. These strategies, as discussed in this chapter, reallocate costs among various segments of the economy.

\section{Stranded Costs: Emergence and Conceptualization ${ }^{173}$}

Regulatory provisions under which the utilities currently operate preclude the possibility of any prudently incurred costs becoming stranded. State regulatory authorities normally set electricity rates in such a way that electricity prices the utilities charge reflect their cost of service. ${ }^{174}$ This is accomplished by setting prices at a level so that total revenues equal total costs. Implementing this process involves a review of a utility's operating costs, its rate base, and the rate of return to be allowed on the rate base. ${ }^{175}$ By adopting this process, the regulatory authorities aim to protect the customer by setting the prices charged to be just sufficient to cover prudently incurred costs. ${ }^{176}$ Generally speaking, this process eliminates any potential for encountering stranded costs.

\footnotetext{
${ }^{170}$ The emerging competitive market for electricity envisions that existing utility customers be able to secure power from alternative albeit lower-priced suppliers. When this occurs, the utility that originally supplied power to a departing customer may not be in a position to market the power sold to the departing customer to an alternative customer. The utility thus suffers a potential financial loss due to structural changes in the industry, leading to the creation of what have commonly been called "stranded costs." FERC's definition of stranded costs has been provided in the preceding chapter. Additional discussion is also provided in this chapter.

${ }^{171}$ Federal Energy Regulatory Commission, Order No. 888, Promoting Wholesale Competition Through Open Access Non-discriminatory Transmission Services by Public Utilities, Docket No. RM95-8-000, and Recovery of Stranded Costs by Public Utilities and Transmitting Utilities, Docket No. RM-94-7001 (April 24, 1996), p. 451.

${ }_{172}$ Ibid., p. 454

${ }^{173}$ Some other terms have also been used by analysts generally to describe stranded costs: strandable investments, stranded investments, stranded assets, stranded commitments, or transition costs. Finer points of distinction can be made on the basis of asset valuation strategies adopted, changes in customers' status, or the financial consequences of moving a regulated industry to a competitive environment. FERC uses the "revenues lost" approach to determine recoverable stranded costs (also called transition costs in the case of natural gas deregulation proceedings). The terms "stranded costs" and "transition costs" are used interchangeably in this chapter even though their definitions are close but not necessarily congruent. Transition costs are stranded costs charged to utility customers through some type of fee or surcharge after the assets are sold or separated from the vertically integrated utility.

${ }^{174}$ Cost of service is a ratemaking concept used in the design and development of utility rate schedules to ensure that the filed rate schedules recover only the cost of providing electricity service. This procedure attempts to correlate the utility's cost and revenue with the service provided to each of the various customer classes. The cost of service is synonymous with the concept of "revenue requirements."

${ }^{175}$ Rate base signifies the value of property on which a utility is permitted to earn a rate of return established by a regulatory authority. It consists of investments (generally valued at historical cost minus depreciation accruals) and other assets used in supplying service to customers. Depending on the method used in its computation, the rate base consists of net plant valuations, cash, working capital and supplies (including fuel inventories), deductions for accumulated provisions of depreciation, contributions in aid of construction, customer advances for construction, accumulated deferred income taxes, and accumulated deferred investment tax credits.

${ }^{176}$ For economists, this method of price formulation equates prices (charged to customers) with average costs. Thus, average cost pricing has been the dominant form of utility regulation.
} 
In a competitive environment, the above conditions change in a fundamental way. The basic difference stems from the manner in which assets are valued in the market. In a regulatory environment, utilities have the assurance of recapturing asset values (adjusted for depreciation) based on historical costs. ${ }^{177}$ In a competitive market there is no comparable assurance, and historical asset costs are of only marginal interest. Asset valuation is determined by current and future income streams. As an example, an asset that does not produce any income (and has no prospects of producing income in the future) has little or no market value, regardless of its original cost.

In the competitive environment, the possibility that prices for electricity could be lower than those ordained in a regulatory regime becomes very real. ${ }^{178}$ This development could, in turn, create a corresponding decline in income streams, thereby causing a downward valuation of a given asset (or a group of them) in the market. This phenomenon leads to what has commonly come to be known as "stranded costs," i.e., that unamortized portion of the original or historical cost of the plant which becomes unrecoverable under conditions of competitive pricing of electricity.

The above example enables us to understand the concept of stranded costs. Stated in simplified terms, stranded costs may be viewed as the excess of value (which is the unamortized portion of historical cost outstanding on a utility's books) of assets over their market value in a competitive power market environment. ${ }^{179}$ Thus the notion of stranded cost creation is based on the concept of costs that were prudently incurred to serve power customers (within a regulatory environment) and which cannot be recovered if the customers move to another lower-cost supplier. ${ }^{180}$

As indicated in the previous chapter, FERC Order 888 recognizes the possibility of stranded costs associated with wholesale and retail (including retail-turned-wholesale) customers using open access transmission service. The
Order states that utilities may recover stranded costs only if they are legitimate, prudent, and verifiable, and only if the utility mitigates the stranded costs by offsetting them by the market value of the power released by the departing customer. The methodology used by FERC in estimating stranded costs is discussed in Appendix E.

Utilities generally visualize a somewhat wider concept of what they call "strandable costs." These include costs that would normally be recovered with the continuation of the current regulatory cost-of-service rate-based regime but are otherwise in excess of the amount that they would recover in an environment of competition unless the transition is compensated. ${ }^{181}$ The main elements included in the wider concept of stranded costs are stranded assets, stranded liabilities, regulatory assets, and stranded social programs. Stranded assets refer primarily to those investments in generation or related assets that would become uneconomic with the advent of competition and which cannot be sold for some reason. Stranded liabilities are primarily contracts with unregulated generators but could also include contracts with fuel suppliers and contingent liabilities such as environmental remediation. Regulatory assets are mainly deferred expenses that appear as assets for the balance sheet in return for the regulatory promise that the utilities will be allowed to recover them in the future. Stranded social programs include a variety of social programs that the utilities have undertaken voluntarily or otherwise by virtue of being a regulated monopoly. Examples include the obligation to provide universal service and to implement crosssubsidized pricing of services, environmental compliance, and demand-side management expenditures. ${ }^{182}$

\section{Magnitude of Potential Stranded Costs}

Estimates of projected stranded costs vary widely, ranging from a low of $\$ 10$ billion to $\$ 20$ billion to a high of $\$ 500$

\footnotetext{
${ }^{177}$ In this approach, all utility assets are valued on the basis of original costs, with adjustments made for depreciation.

${ }^{178}$ Assuming that the current utility franchised operations represent a monopoly, it is easy to see that monopoly prices will invariably be higher than those likely to be determined under conditions of competition. There is, however, no implication that the utilities do charge monopoly prices. In fact, utility regulation is designed to ensure that utilities do not earn monopoly profits but charge rates that are just and reasonable. Yet, there are a host of reasons why prices charged by utilities in some areas may be higher than those that would prevail under competitive conditions.

${ }^{179}$ The converse is equally possible, implying that the market value of an asset may be higher than its historical cost valuation. In such cases, there will be no "stranded costs" or "lost revenues." In both cases, however, changes in income streams (other things being equal) cause corresponding changes in the valuation of an asset.

${ }^{180}$ Within the above framework, the composition of stranded costs will be dominated by generating capacity. However, additional categories of costs could also be included in the broader definition of stranded costs, as discussed later in this chapter. All costs included in the rate base are assumed to have been prudently incurred.

${ }_{181}$ Niagara Mohawk Power Corporation filing with the New York Public Service Commission in PSC Case Nos. 94-E-0098 and 94-E-0099, Phase II, Multi-Year Electric Rate, Restructuring and Retail Access Proposal (Syracuse, NY, October 6, 1995).

${ }^{182}$ See Appendix E, "Stranded Costs."
} 
billion, depending on the assumptions and methodology used. The low estimates of stranded costs are attributable to the American Public Power Association (APPA). APPA claims that about 5 to 10 percent of the capacity assets of the investor-owned utilities may become stranded. ${ }^{183}$ The high estimates come from many sources, including the Edison Electric Institute, Resource Data International, National Economic Research Associates (NERA), and others. Some of these estimates include other elements of costs (liabilities associated with power purchase contracts, regulatory assets, and others) that have the potential to be stranded. ${ }^{184}$

NERA, for example, estimates the stranded costs to be the difference between the short-run marginal costs of generation (in the range of 2 to 3 cents per kilowatthour) and the average cost (in the range of 5 cents per kilowatthour) for an unknown time period, so that its estimate of $\$ 500$ billion is at the upper end of the spectrum. ${ }^{185}$ Moody's Investor Service's (Moody's) estimate of total stranded costs for the investor-owned utilities is in the range of $\$ 50$ billion to $\$ 300$ billion, depending on market price assumptions. However, Moody's most likely scenario estimates stranded costs to be $\$ 135$ billion, with the highest concentration of costs among the utilities in the Northeast and the West accounting for more than 40 percent of the industry's total stranded costs. ${ }^{186}$

Variances in available estimates of stranded costs stem from the assumptions made with respect to critical variables in the process. Assumptions that significantly affect projected levels of stranded costs include the share of retail electricity sales subject to competition, the projected market clearing price of electricity, and the number of years used in computing stranded investments. Higher estimates of stranded costs may be linked with more pessimistic perspectives regarding utilities' loss of market share or their lack of resilience in the adjustment process to lower the price or find alternatives to sales of at-risk capacity. Accordingly, some analysts contend that the "industry estimate seems to grossly overestimate the reduction in the value of utility assets." ${ }^{187}$

There is, however, no implication that projections of stranded costs at the lower end of the spectrum are more realistic than those at the upper end. For the most part, all estimates have been made under the proverbial "what if" conditions brought about by differences in perspective. The yet-to-evolve characteristics of the market, the role of its new players, and the level of future natural gas prices are all unknowns. In addition, the availability of reliable data with respect to the unamortized costs (or investments) together with related plant operating data pose another nontrivial estimation problem. Any of these factors, singly or jointly, can cause serious biases in projecting stranded costs.

In addition, there are those who seriously believe that a major segment of stranded costs may be attributable to domestic nuclear power plants. According to one study, of the nearly $\$ 120$ billion in undepreciated assets in domestic nuclear power plants, nearly 60 percent (or about $\$ 70$ billion) may be "stranded" in a competitive environment. ${ }^{188}$ It is possible that these estimates are not only influenced by uncertainties with respect to the future but also by the assumption that the affected utilities may not be able to take any action to correct observable cost imbalances within the foreseeable future.

A more recent study (assuming that deregulation and restructuring of the industry would be completed by the end of 1996) estimates the nuclear investment at risk to be $\$ 63$ billion if the competitive markets take effect at the beginning of 1997 . In the more likely event that restructuring is fully effected by the year 2000 , the at-risk investment in nuclear power plants would decline to $\$ 43$ billion and to $\$ 10$ billion for the 2010 time frame. The postulated time period for the industry's transition is, therefore, another critical variable in the estimation of potential stranded costs or investment at risk. ${ }^{189}$

\footnotetext{
183 "Comments" and "Reply Comments" submitted by the American Public Power Association in the matter of "Recovery of Stranded Costs by Public Utilities and Transmitting Utilities" before the Federal Energy Regulatory Commission on December 6, 1994, and January 23, 1995, respectively.

${ }^{184}$ For a discussion of what the range of estimates really means, refer to Oak Ridge National Laboratory, Estimating Potential Stranded Commitments for U.S. Investor-Owned Electric Utilities, ORNL/CON-406 (Oak Ridge, TN, January 1995), pp. 3-6.

${ }^{185}$ National Economic Research Associates, Rewriting the Rules of the Road: Retail Wheeling and Competition in Electric Generation (New York, NY, March 1994).

${ }^{186}$ Defining break-even price as the minimum price that a utility must charge to fully recover its fixed production costs, Moody's estimates the difference between a utility's break-even price and the market price for that capacity. Multiplying the difference by the total of a utility's capacity enables the derivation of stranded costs for any given year. These projections are extended for a 10-year period and then appropriately discounted to yield a net present value. For additional details see Moody's Investor Service, Stranded Costs Will Threaten Credit Quality of U.S. Electrics (New York, NY, August 1995).

${ }^{187}$ National Regulatory Research Institute, The Regulatory Treatment of Embedded Costs Exceeding Market Prices: Transition to a Competitive Electric Generation Market-A Briefing Document for State Commissions (Columbus, OH, November 1994), p. 8.

${ }^{188}$ M. D. Yokell, D. Doyle and R. Koppe, "Stranded Nuclear Assets and What to Do About Them," presentation to the DOE-NARUC Electricity Forum (Providence, RI, April 1995).

${ }^{189}$ See J. H. Wile, "What Do You Mean My Stranded Costs Are Uncertain?" presentation made to the Financing the Future of the Electric and Gas Industries Conference (Chicago, IL, July 25, 1996).
} 
Another study comes up with estimates nearly the same as the above but for reasons that differ slightly. Data Resources Incorporated (DRI) has come up with estimates of stranded costs for each Census division, based on the difference between the region's industrial electricity price (less transmission and distribution costs) and the long-run marginal generation cost, multiplied by the volume of electricity demand expected to be at risk in the region (Table 6). ${ }^{190}$ The amount of stranded assets is estimated at $\$ 88$ billion, with their net present valuation being $\$ 67$ billion. ${ }^{191}$ The distribution of these assets is quite polarized, with New England and California being at maximum risk for one-third to one-half of their rate base. At the other extreme are low-cost regions with no assets at risk (Table 7 and Figure 14).

Detailed descriptions of different approaches to estimating stranded costs are contained in Appendix $E$.

\section{Mitigation Requirements in Recovery of Stranded Costs}

Under the FERC's procedures, a utility seeking to recover its stranded costs will be required to show that it has taken or will take reasonable and prudent measures to mitigate stranded costs. ${ }^{192}$ Although FERC received support for requiring that mitigation measures be taken, there is prevailing ambivalence on how to adopt mitigation measures for them to be effective and how to deal with those stranded costs that are difficult to mitigate. ${ }^{193}$ In issuing Order 888, FERC upheld the view that its "revenues lost" approach for determining stranded costs encompasses mitigation measures. Since this aspect will be critically examined in the future, mitigation options that are available need to be carefully examined.

\section{Mitigation Strategies To Address Stranded Costs}

How to address stranded costs has become a critical issue in promoting competition in the electricity industry. FERC's Mega-NOPR provides a discussion of the options suggested by utilities, regulators, and other interested parties that could be used in mitigating the level of stranded costs likely to confront a utility. These strategies are more commonly known as "mitigation" strategies designed to reduce the burden that utilities and their shareholders will otherwise be required to shoulder.

Table 6. Average and Marginal Cost of Electricity Production by Census Division, 1995 (Cents per Kilowatthour)

\begin{tabular}{|c|c|c|c|}
\hline Census Region & Marginal Cost & Average Electricity Price & Difference \\
\hline New England ........ & 3.9 & 9.9 & -5.9 \\
\hline Pacific 2 & 4.1 & 9.2 & -5.0 \\
\hline Middle Atlantic & 3.9 & 9.2 & -5.2 \\
\hline Mountain $2 \ldots \ldots \ldots \ldots \ldots$ & 3.8 & 7.7 & -3.9 \\
\hline South Atlantic . ........ & 3.9 & 6.4 & -2.5 \\
\hline East North Central .................. & 3.9 & 6.0 & -2.1 \\
\hline West North Central ..... & 3.7 & 5.8 & -2.1 \\
\hline East South Central & 3.7 & 5.3 & -1.6 \\
\hline West South Central ... & 3.8 & 6.1 & -2.2 \\
\hline$\ldots \ldots \ldots \ldots \ldots \ldots \ldots \ldots$ & 3.8 & 5.5 & -1.7 \\
\hline Pacific $1 \ldots \ldots \ldots \ldots \ldots \ldots \ldots \ldots$ & 3.8 & 4.2 & -0.3 \\
\hline
\end{tabular}

Source: DRI/McGraw Hill, World Energy Service-U.S. Outlook: FallWinter 1996 (Lexington, MA, 1996), p. 44.

\footnotetext{
${ }^{190}$ The long-run marginal costs are defined by the levelized costs associated with either a 200 -megawatt dual-fired combined-cycle unit, with efficient heat rate and low operating costs, or a 200-megawatt coal unit with access to cheap western coal. The volume of demand at risk was approximated by the size of the industrial load.

${ }^{191}$ The net present valuation asset estimation assumes that assets are stranded in equal proportions over the 1997-2002 period.

${ }^{192}$ Federal Energy Regulatory Commission, Recovery of Stranded Costs by Public Utilities and Transmitting Utilities, Docket No. RM94-7-000 (Washington, DC, June 29, 1994).

${ }^{193}$ Ibid., p. 321
} 


\begin{tabular}{|c|c|c|c|}
\hline & Stranded Costs ${ }^{a}$ & $\begin{array}{l}\text { Present Value of } \\
\text { Stranded Costs }\end{array}$ & $\begin{array}{c}\text { Present Value as } \\
\text { Share of Current } \\
\text { Rate Base }\end{array}$ \\
\hline & \multicolumn{2}{|c|}{ Billion Dollars } & Percent \\
\hline New England & 16.6 & 12.7 & 59 \\
\hline Middle Atlantic .......... & 21.5 & 16.5 & 24 \\
\hline South Atlantic ...... & 12.2 & 9.3 & 13 \\
\hline East North Central & 0.0 & 0.0 & 0 \\
\hline West North Central $\ldots \ldots \ldots \ldots \ldots \ldots \ldots$ & 2.7 & 2.0 & 8 \\
\hline East South Central & 7.5 & 5.8 & 35 \\
\hline West South Central & 0.0 & 0.0 & 0 \\
\hline Mountain $1 \ldots \ldots \ldots \ldots \ldots \ldots \ldots \ldots$ & 0.0 & 0.0 & 0 \\
\hline Mountain $2 \ldots \ldots \ldots \ldots \ldots \ldots \ldots \ldots \ldots$ & 34.0 & 2.6 & 18 \\
\hline Pacific $1 \ldots \ldots \ldots \ldots \ldots \ldots \ldots \ldots \ldots \ldots \ldots \ldots$ & 0.0 & 0.0 & 0 \\
\hline Pacific $2 \ldots \ldots \ldots \ldots \ldots \ldots \ldots \ldots \ldots \ldots \ldots \ldots \ldots \ldots$ & 24.0 & 18.4 & 54 \\
\hline U.S. Total $\ldots \ldots \ldots \ldots \ldots \ldots \ldots \ldots \ldots \ldots$ & 87.8 & 67.3 & 17 \\
\hline
\end{tabular}

aStranded costs by region are estimated by DRI based on the difference between the region's average industrial electricity price and the cost of new generation. This approach misses stranded costs associated with high-cost generating plants in regions dominated by low-cost generating plants, such as East North Central, West South Central, Mountain 1, and Pacific 1. While stranded costs may not be zero in these regions, they are expected to be significantly lower than in the coastal regions.

Source: DRI/McGraw Hill, World Energy Service-U.S. Outlook: FallWinter 1996 (Lexington, MA, 1996), p. 44.

Figure 14. Estimates of Stranded Costs by Census Division, 1995 (Billion Dollars)

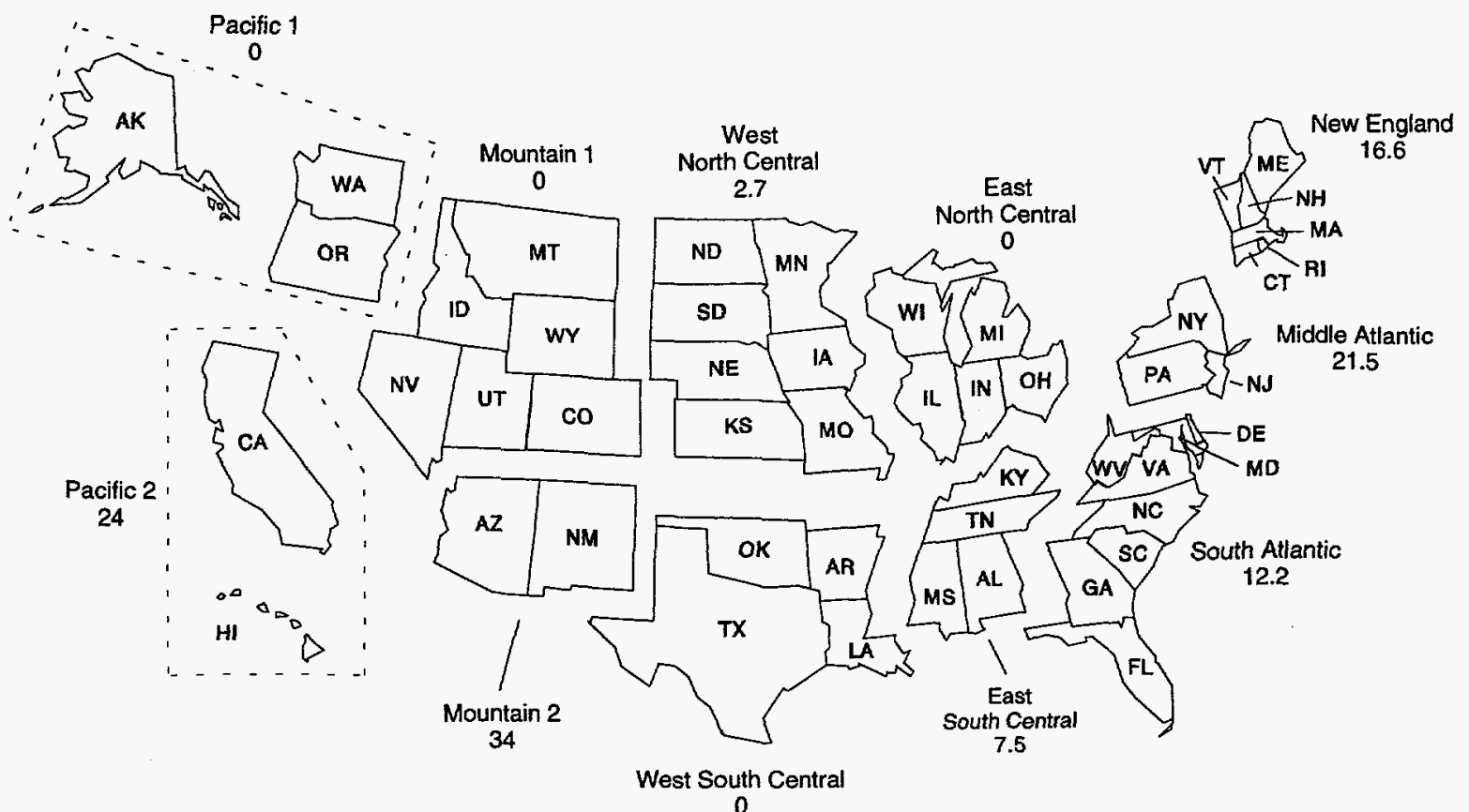

Source: DRI/McGraw Hill, World Energy Service-U.S. Outlook: FallWinter 1996 (Lexington, MA, 1996). 
An important caveat, in connection with the adoption of strategies to mitigate stranded or transition costs, should be kept in mind. Stranded costs, to the extent that they reflect sunk costs or obligations, cannot by definition be mitigated. Thus, nearly all the "mitigation" strategies aim to shift stranded costs among differing segments of the economy. The potential candidates for absorbing all or a portion of the stranded costs include the utility shareholders, ratepayers, taxpayers, wheeling customers, or independent power producers (including qualifying facilities [QFs]). In some cases, suggestions have been made for the State or the Federal Government to bear these costs in some manner.

It should also be noted that not all the mitigation strategies that have been discussed or recommended in the past are based on considerations of equity or fairness when it comes to deciding who should bear the burden of stranded costs. The basic intent is to lower or reduce the level of stranded costs that utilities may otherwise be required to absorb. As indicated in the previous chapter, FERC favors the notion that a utility be allowed to recover its stranded costs subject to providing evidentiary demonstration that "it has taken and will take reasonable and prudent measures to mitigate stranded costs." ${ }^{194}$ FERC recognized that failure to deal with the stranded cost problem could delay the transition to a fully competitive, open access environment. It could also destabilize the financial integrity of the industry. In a sense, FERC legitimized the notion of adopting mitigation strategies as being an integral part of the recovery mechanism.

The above developments explain the growing interest in developing mitigation strategies that can be used to lower the utilities' burden in absorbing stranded costs. These are discussed next. Note that difficulties arise in providing a comparative evaluation of mitigation strategies in the absence of a fully developed analytical background.

\section{Results of Mitigation Strategies}

Since the release of FERC's stranded costs NOPR in 1994, interest in developing mitigation strategies has intensified. A discussion of all mitigation strategies developed since then is provided in Appendix $\mathrm{E}$.
These strategies are applied to a hypothetical utility and their impact is assessed by using a financial modelORFIN (Appendix D). The assessment process involves incorporating a specific strategy into a planning and production costing model to estimate the resulting financial consequences. Data for an actual utility facing substantial strandable costs were used for this hypothetical analysis. The estimate of each strategy's effect is the difference in strandable costs (or transition costs) due to retail competition with and without the strategy.

Reasonably complete representations of various selected strategies were incorporated in the model to evaluate their impacts with a view to distinguish between strategies that may have large effects from those with smaller effects. Mitigation strategies selected included market options, depreciation options, ratemaking options, utility cost reduction options, and other approaches.

If retail competition began in 1996, and by 199860 percent of this utility's commercial and industrial customers choose alternate suppliers, net present value of this utility's stranded costs are estimated to be $\$ 2.45$ billion, representing 77 percent of the firm's 1995 equity. Mitigation strategies will alter the utility's losses. Subject to the above observations, the following summary results were obtained.

\section{Strategies with Large Impacts}

- For at-risk utilities, delaying retail wheeling, charging exit fees to departing customers, reducing administrative and general costs, and discounting QF energy payments are all likely to result in large reductions of 25 percent or more in the base case utility's stranded costs (i.e., more than $\$ 600$ million). As an example, delaying retail wheeling by 2 years reduces the strandable costs by $\$ 790$ million.

- The nongeneration cost reduction potential (as applied exclusively to the specifics of the hypothesized base case utility) is found to be high, exceeding $\$ 1.0$ billion. Possibilities of securing additional reductions are also identified in areas of the base case utility's nongeneration costs (e.g., customer service, operations and maintenance related to transmission and distribution) primarily because

${ }^{194}$ Federal En:rgy Regulatory Commission, Notice of Proposed Rulemaking and Supplemental Notice of Proposed Rulemaking (March 29, 1995). The NOPR is made up of two dockets: (1) Promoting Wholesale Competition Through Open Access Nondiscriminatory Transmission Services by Public Utilities, Docket No. RM95-8-000, and (2) Recovery of Stranded Costs by Public Utilities and Transmitting Utilities, Docket No. RM94-7-001. 
of its comparatively higher costs in comparison with benchmark performance data.

- Rapidly opening retail markets increases the level of strandable costs significantly. If the assumption that all retail customers wheel from alternative sources by the year 2000 is incorporated in the ORFIN model, this strategy increases transition costs to $\$ 4.8$ billion.

- Imposing exit fees (of one kind or another) on departing wholesale and retail customers is a strategy that has wide support. The exit fees can be computed as a one-time charge or could be structured as a stream of payments. ${ }^{195}$ Assuming that the exit fees are paid in a lump sum when the customers leave the system, the impact can be substantial. The Oak Ridge study (which uses two approaches in estimating exit fees) indicates that nearly all the stranded costs can be met from the proceeds of exit fees, with net gains resulting under more optimistic conditions.

- The effects of a utility's marketing energy freed by the departing retail customers are difficult to assess, with the result that transition costs can go down modestly or increase significantly. The benefits (or costs) of marketing excess energy (for the base case utility) are related to the marginal generation costs of the utility's own plants and operations, the cost obligations of its power purchase contracts, and the characteristics of the wholesale market. Utilities with substantial transmission capacity will find marketing to be a more effective strategy than will utilities without sufficient interconnections. ${ }^{196}$

- Strategies to discount or reduce power purchase costs potentially produce large cost reductions primarily because the base case utility has must-run power purchase contracts at costs that are significantly higher than the average market costs. ${ }^{197}$
Power purchase contracts could be renegotiated with regard to payments for capacity or energy. Other options include substituting dispatchability in lieu of the "mustrun" provisions or an outright buyout. Depending on the nature of the strategy adopted and the longevity of the power purchase contract obligations, the savings could be large, exceeding the base case utility's total transition costs. $^{198}$

\section{Strategies with Medium Impacts}

- Strategies with medium effects (reflecting changes from 5 to 25 percent, i.e., $\$ 120$ million to $\$ 600$ million) that potentially reduce strandable costs include imposition of charges for ancillary services; reductions in customer-service costs, transmission and distribution operating and maintenance (O\&M) costs, and generation O\&M costs; and discounting QF capacity payments to market.

- A strategy to accelerate depreciation payments (of generation plants) can have significant effects on stranded costs, particularly if the policy is pursued in isolation.

- The absolute effects (positive or negative) of increasing system load factors depends on the magnitude of load factor changes. Attempts to reduce onpeak demand may reduce revenues, whereas increasing off-peak sales may increase revenues.

\section{Strategies with Modest Impacts}

- The strategy of reducing public policy programs has only modest effects (i.e., where changes are less than 5 percent or less than $\$ 120$ million) on transition costs, depending on the size of initial programs and the extent of the reductions.

- The impact of offsetting increased cost of accelerated depreciation by decelerating the depreciation of

\footnotetext{
${ }^{195}$ For the sake of simplicity, the Oak Ridge study assumes that the customers pay an exit fee the year they take wheeling service. An algebraic formulation computes the net present value of the exit fees for different customer classes, depending on the year they leave, with the end point for all customer classes being 2018. Two variations of the exit fees are calculated: (1) the difference between total generation and market generation costs is kept constant over time, and (2) the difference is allowed to change over time.

${ }^{196}$ The hypothesized base case utility has an abundance of power-purchase contracts without dispatchability provisions. Actions that the utility takes to reduce these costs, particularly the energy payments, through renegotiation or buyout of these contracts will have significant impacts on its strandable costs. The ability to sustain long-term nondispatchable power-purchase contracts with fixed payments well above current or anticipated market prices is a major issue confronting the industry.

${ }^{197}$ The base case utility pays an average price of 7.2 cents per kilowatthour for its power purchases, as compared with the average market price of 2.5 cents per kilowatthour.

${ }^{198}$ Strategies to lower the costs of purchased power entail some form of resistance from independent power producers, which may not always be possible to eliminate but can be moderated.
} 
other assets depends on when the change begins. If the change is initiated before the commencement of retail wheeling, strandable costs decline. In the alternative, strandable costs are likely to increase. Similar timing considerations apply with respect to the acceleration of regulatory assets.

\section{Concluding Remarks}

Most of the strategies examined here require the tacit cooperation of other parties, including the regulators, for successful implementation. Accordingly, who should share how much of the anticipated burden is likely to be decided by a consensus approach among the various segments of the economy, again including the regulators. Utilities may or may not be able to recover all that they may want to include in stranded cost computations, but recent developments in California and Rhode Island offer encouragement. The operational impact of policies permitting stranded cost recovery (at the State or Federal level) may be to provide a reasonable period of transition to ensure the financial integrity of the industry. Electricity supplies and deliverability could thus be assured for the future. 


\section{Transitional Developments and Strategies: The Industry Prepares for Competition}

As has been described in the preceding chapters, many changes in the structure and operations of the electric power industry are now taking place. This chapter discusses the actions that different segments of the industry are taking to prepare for the future and some of the new developments in the industry. It is intended to provide a snapshot of an industry undergoing significant change that probably will extend into the next century.

\section{Investor-Owned Utilities}

For more than a century, vertically integrated investorowned utilities (IOUs) have produced and sold most of the electricity in the United States. In 1995, they accounted for about 75 percent of retail and about 40 percent of wholesale electricity sales. ${ }^{199}$ As competition increases, however, their dominant position is being challenged. New generating capacity can be built and operated at prices substantially lower than the price of some electricity sold by electric utilities, and open transmission access will give electricity customers more choices of wholesale electricity suppliers. As a result, high-priced suppliers will lose customers to low-priced suppliers.

To stay competitive and to prepare for a future industry that will be very different from the past, IOUs are looking for ways to lower their electricity prices. The average price of electricity is based on the utility's cost of service, which usually includes a return on capital. In 1995, IOUs received $\$ 184$ billion in electric operating revenues, which covered operating and maintenance expenses (O\&M), depreciation and amortization expenses, and Federal and State taxes (Figure 15). The remaining revenues were operating income, used to pay interest on long-term debt, to pay dividends to investors, and to save as retained earnings. Since almost 57 percent of the revenues were used to pay for O\&M activities, including fuel, keeping these expenses under control is important in maintaining

\section{Figure 15. Allocation of Revenue Dollars from Electric Operations for Major U.S. Investor-Owned Utilities, 1995}

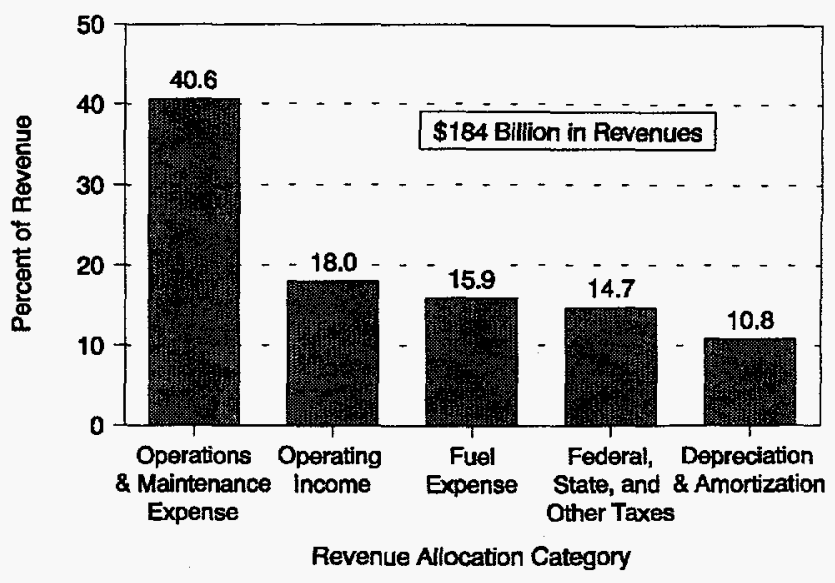

Note: Totals may not equal sum of components due to independent rounding.

Source: Energy Information Administration, Financial Statistics of Major U.S. Investor-Owned Electric Utilities 1995, DOE/EIA-0437(95/1) (Washington, DC, December 1996).

competitive electricity prices. In that regard, IOUs are taking specific actions to lower O\&M expenses. Staff reductions are the most visible cost-cutting strategy. Some companies are merging, or planning to merge, to eliminate redundant functions and to obtain synergies.

\section{General Trends in Operating and Maintenance Expenses of Investor-Owned Utilities}

O\&M activities in the electric power industry-which totaled $\$ 104$ billion in 1995 -include power production, power purchases, transmission and distribution of power, customer services, and administrative and general acti-

\footnotetext{
${ }^{199}$ Energy Information Administration, Financial Statistics of Major U.S. Investor-Owned Electric Utilities 1995, DOE/EIA-0437(95/1) (Washington, DC, December 1996).
} 
vities. In 1995, power production accounted for almost 45 percent of O\&M expenses, followed by power purchases at nearly 29 percent and administrative and general and customer service and sales expenses at 19 percent (Figure 16). This distribution illustrates how O\&M expenses are allocated among the activities of the company; however, with more price competition likely, it is important to have a downward trend in these expenses. As a group, IOUs have achieved some success in lowering costs. Real O\&M costs have decreased by 22 percent from about 4.5 cents per kilowatthour (kWh) in 1986 to 3.5 cents per $\mathrm{kWh}$ in 1995 (Figure 17). Lower fuel prices accounted for most of the reduction in O\&M expenses. Over the same years, non-fuel O\&M costs were relatively stable at about 2.6 cents per $\mathrm{kWh}$, indicating perhaps that more effective non-fuel cost reduction activities are needed.

Lower coal prices, brought about by excess coal production capacity and changing market conditions, provided the largest reduction in industry fuel costs. ${ }^{200}$ With more than 55 percent of the electricity generated in the United States coming from coal-fired plants, lower coal prices make a big difference in average fuel costs. As coal prices dropped, many utilities found it economical to "buy out" older, more expensive contracts and increase purchases under newer, less expensive contracts, or to increase purchases of less expensive coal from the spot

\section{Figure 16. Allocation of Electric Operation and Maintenance Expenses of Major U.S. Investor-Owned Utilities, 1995}

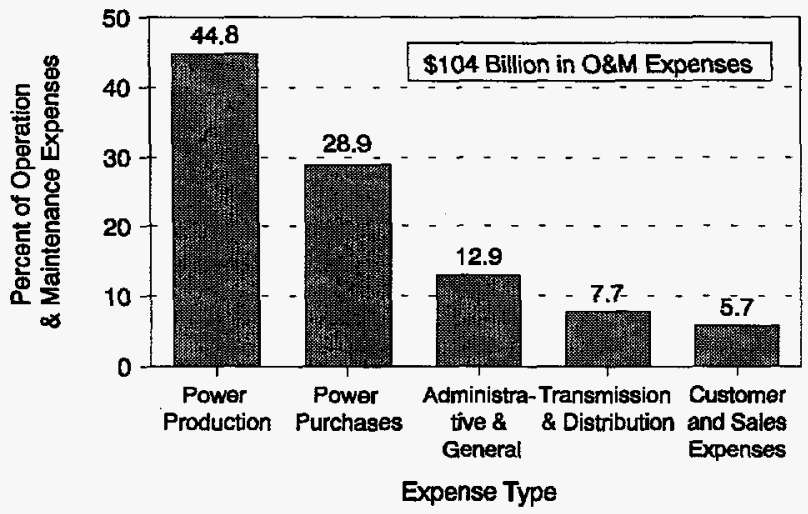

Source: Energy Information Administration, Financial Statistics of Major U.S. Investor-Owned Electric Utilities 1995, DOE/EIA-0437(95/1) (Washington, DC, December 1996). market. For example, Duke Power estimated a net saving of about $\$ 13.6$ million from a buyout of its coal supply contract with Westmoreland Coal Company. Officials at Duke Power were confident that coal could be purchased under short-term contracts or in the spot market at prices well below those in the contract. ${ }^{201}$ Other utilities were able to reduce the costs of transporting coal to their plants by renegotiation of contracts or by taking advantage of increased competition among the carriers. Increasing purchases of low-cost western coal also helped reduce fuel costs for coal-fired plants.

Besides coal, the costs of other fuels have decreased over the past few years. Average wellhead prices for natural gas have generally declined from 1987 through 1994, with a brief upward trend in 1992 and early 1993. Gas-fired plants produce about 10 percent of electricity in the United States. A large worldwide surplus of uranium has also caused its prices to decrease over the past decade or more. Nuclear plants, which use enriched uranium, produce about 22 percent of the electricity in the United States.

In addition to lower fuel costs, many IOUs have significantly reduced their workforce and lowered their payroll expenses through attrition, early retirement, and voluntary and involuntary severance. From 1986 to 1995, employment at major IOUs decreased by about 20 percent, a reduction of more than 100,000 employees (Figure 17). Real salaries and wages decreased by 28 percent, from about 0.7 cent per $\mathrm{kWh}$ in 1986 to about 0.5 cent per kWh in 1995 (Figure 17).

In an increasingly competitive industry, staff reductions and downsizing are likely to continue. Many utilities have announced plans to revamp their organizational structures, streamline operations, and reduce staff. CINergy-a holding company of Cincinnati Gas and Electric and PSI Energy with a combined total of over 7,300 electricity-related employees-plans to cut its workforce by 5 percent through retirement and severance arrangements. Another holding company, Centerior Energy- which includes Cleveland Electric Illuminating and Toledo Edison and has a combined total of more than 5,400 electricity employees-is planning to retire three coal plants and eliminate 500 jobs, or 9 percent of its electricity employment. Centerior officials have said that these actions are part of a company program to reduce costs and to improve its competitive position. ${ }^{202}$

\footnotetext{
${ }^{200}$ Energy Information Administration, Cost and Quality of Fuels For Electric Utility Plants 1994, DOE/EIA-0191(94) (Washington, DC, July 1995). 201 "Duke Expects \$13.6-Million Savings From One-Year Buy-out of Coal Pact," Electric Utility Week (August 28, 1995 ), p. 10.

202 "Centerior Retiring Three Coal Plants, Eliminating 500 Jobs To Cut Costs," Electric Utility Week (May 20, 1996), p. 3.
} 
Figure 17. Trends in Operation and Maintenance Expenses of Investor-Owned Utilities, 1986-1995

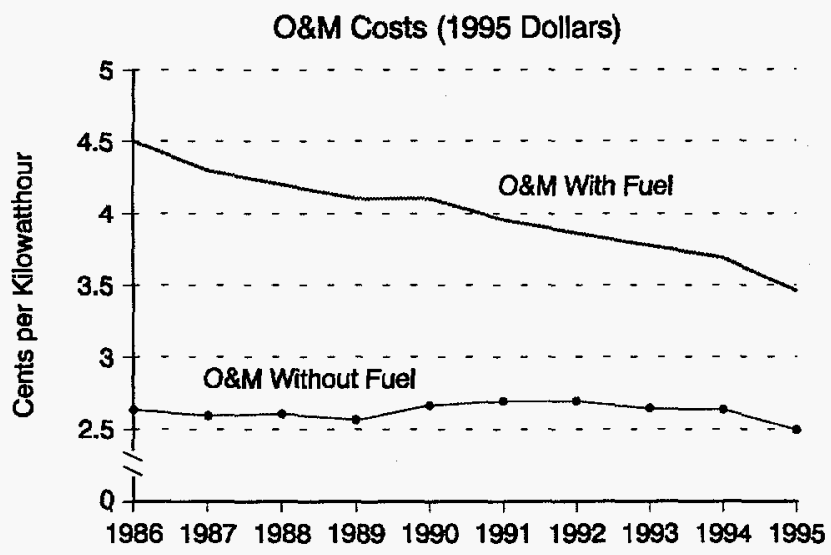

Operation and Maintenance expenses of major IOUs decreased from 4.5 cents per $\mathrm{kWh}$ in 1986 to 3.5 cents per $k W h$ in 1995. Declining fuel costs are the main reason for lower O\&M costs.

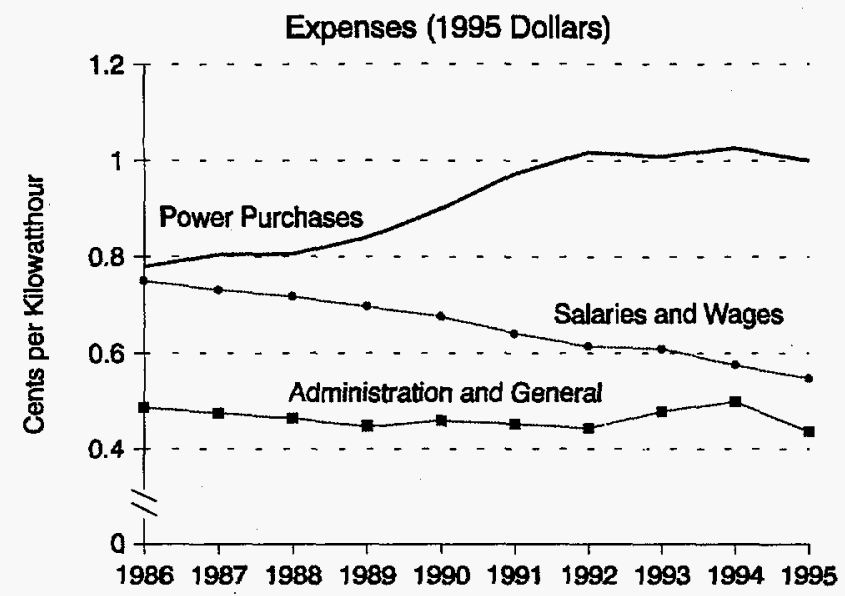

With employment cuts, salary and wage expenses decreased, but the savings were offset by increases in power purchases and administration and general expenses.

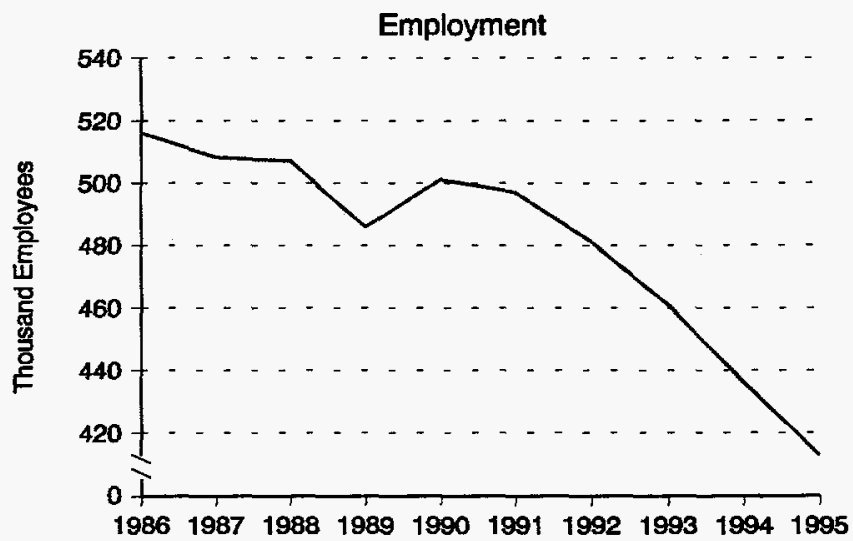

Over the last decade, major IOUs have reduced employment by about 100,000 .

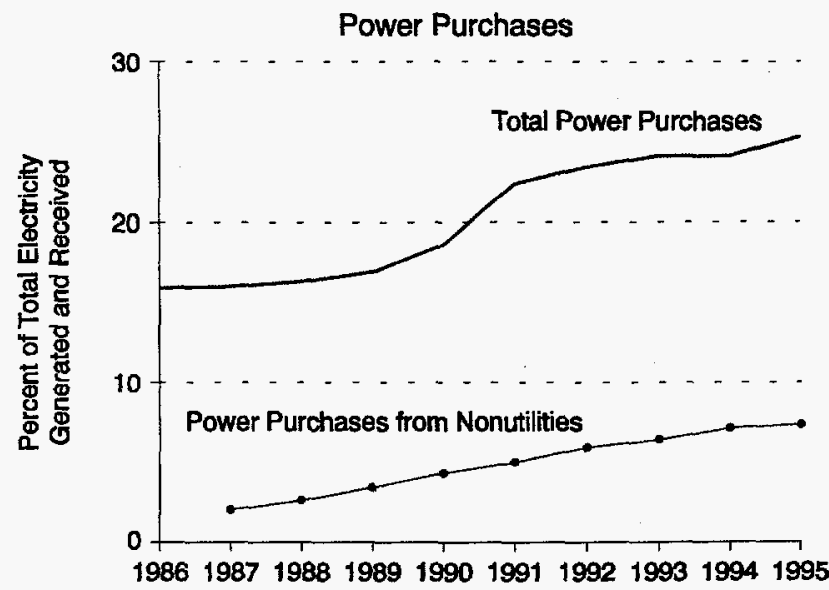

Purchases of electricity increased to about 25 percent of the total electricity available for sale in 1995. Purchases from nonutilities increased to 7 percent of the total.

Source: Energy Information Administration, Financial Statistics of Major U.S. Investor Owned Electric Utilities 1995, DOE/EIA-0437(95/1) (Washington, DC, December 1996), and previous issues.

Utilities, relying more on purchased power now than in the past to meet their power needs, are finding that the relatively high cost of purchased power hinders their efforts to reduce O\&M costs. In the late 1980s, IOUs purchased about 16 percent of their power needs, compared with more than 25 percent in 1995. The share of
O\&M costs attributable to purchased power has increased steadily since 1988 , reaching a high of almost 1.0 cent per $\mathrm{kWh}$ in 1992, where it has remained through 1995 (Figure 17). ${ }^{203}$ Some industry analysts believe that the requirement in the Public Utility Regulatory Policies Act (PURPA) for utilities to purchase electricity from qualified

${ }^{203}$ The per-kilowatthour cost of purchased power is computed using total net energy generated and received. This reflects the increasing role of high cost purchased power relative to energy generated by the utility. The actual cost of purchased power has been decreasing, but it is still higher than the cost of utility-generated electricity. In 1995 , the average direct cost of purchased power was 3.94 cents per kWh compared to 3.29 cents per kWh for utilitygenerated electricity. 
independent power producers at the avoided cost of production caused, at least in part, these costs to escalate. Many utilities are now finding that their avoided costs are less than originally anticipated, and they are challenging the contracts signed in the early days of PURPA.

Some utilities are trying to buy out existing purchase contracts in order to reduce costs. For example, Pennsylvania Power and Light (PP\&L) will pay $\$ 91$ million to a nonutility generator to terminate its contract for 100 megawatts of capacity from a coal gasification project. Because the original contract was signed in 1985, when the utility's avoided costs for power were higher than today's costs, PP\&L claims that, even at this high buyout price, it will save $\$ 114$ million over the next 13 years. ${ }^{204}$ Perhaps a more visible example is the Niagara Mohawk buyout, in which Niagara offered to buy out contracts from 19 of its largest independent suppliers and indicated that if the public utility commission failed to make some concessions on the independent suppliers' contracts, the company might file for bankruptcy. ${ }^{205}$

Administration and general (A\&G) expenses have also increased over the past few years, reaching almost 0.5 cent per $\mathrm{kWh}$ in 1994 (Figure 17). In 1995, they decreased to about 0.4 cent per $\mathrm{kWh}$. Higher-than-normal employee pensions and benefit expenses, caused by large staff reductions with expenditures for early retirement bonuses, employee buyouts, and employee severance pay, are responsible for most of the fluctuation in these expenses. In 1994, for example, major IOUs spent more than $\$ 5.4$ billion (38 percent of total A\&G expenses) on pensions and employee benefits, decreasing to $\$ 4.2$ billion (33 percent of total A\&G expenses) in 1995. With more staff reductions planned, however, it is expected that these expenditures will be high for the near future, and then decrease as utilities complete their downsizing activities.

\section{Mergers and Acquisitions of Investor- Owned Utilities}

A second way in which IOUs plan to improve their competitive position is through mergers and acquisitions.
By creating a larger customer base, more control of transmissions lines, or lower average costs, a merger can potentially strengthen the resulting company in several ways. Articles reporting that utility executives have met to discuss the possibility of merging appear fairly frequently in recent editions of newspapers and trade journals. The motives, according to utility executives, are to combine resources, eliminate redundant operations, and reduce costs, all of which are necessary to stay competitive.

Mergers are not new to the electric power industry. Over the past 10 years, 38 electric IOUs have merged with other utilities in the industry. In 1986 there were 282 IOUs, of which 182 were "major" IOUs. By 1995, there were 244 IOUs remaining, of which 179 were major IOUs (Figure 18). ${ }^{206} 207$ It appears that the trend of IOU consolidation is continuing, and that major IOUs are getting larger by merging with smaller utilities.

In the United States, it is fairly common for private companies to merge with or acquire other companies. A

\section{Figure 18. Number of Investor-Owned Electric Utilities, 1986-1995}

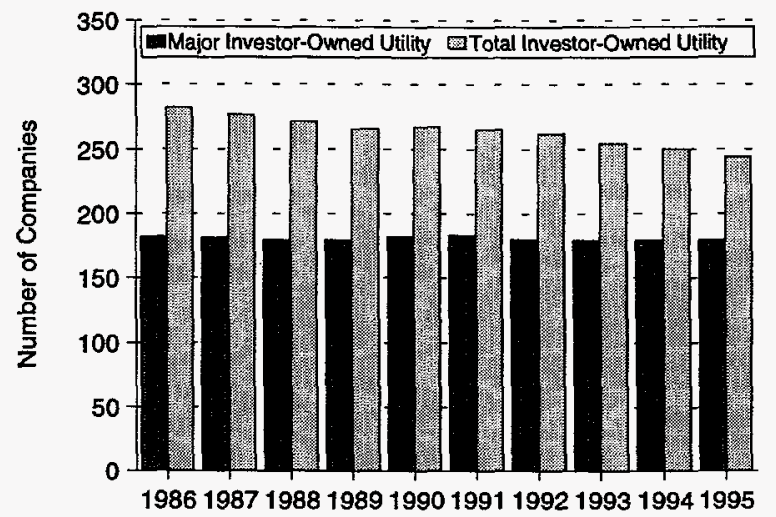

Source: Energy Information Administration, Financial Statistics of Major U.S. Investor-Owned Electric Utilities 1995, DOE/EIA-0437(95/1) (Washington, DC, December 1996), and previous issues.

204 " PP\&L to Pay $\$ 91$ Million to NUG Plant To Stop Buying 100 MW Under Old Pact," Electric Utility Week (March 4, 1996$)$, p. 4.

205 "Independent Electric Producers Losing Power Struggle," Wall Street Journal (August 15, 1996).

${ }^{206}$ Although there were 244 operating companies in 1995, consolidation is greater than the numbers indicate. Some of these operating companies are subsidiaries of holding companies. For example, Alabama Power, Georgia Power, Gulf Power, Mississippi Power, and Savannah Electric and Power are subsidiaries of the Southern Company, a registered holding company.

${ }^{207}$ Major investor-owned utilities are defined as having in the past 3 consecutive years one or more of the following: (1) 1 million megawatthours of annual sales, (2) 100 megawatthours of annual sales for resale, (3) 500 megawatthours of annual power exchanges delivered, or (4) 500 megawatthours of annual wheeling for others. 
company seeking to improve its operating efficiency, increase its market share and profits, or expand its product line may find that it can accomplish one or more of these goals through a merger. IOUs share these broad goals, and many of them have merged with or acquired other utilities to help meet their business objectives. The electric utility industry has a long history of mergers, starting in the early 1900s. ${ }^{208}$ From 1917 through 1930, consolidations of electric utilities were more common than at any other time in the history of the industry. They occurred at a rate of more than 200 per year, peaking at over 300 per year in the mid-1920s. ${ }^{209}$ Most of the mergers in the 1920 s combined small operating companies into large holding companies. In the early 1930s many of the holding companies collapsed financially. The Federal Trade Commission (FTC) investigated the situation and uncovered a host of financial abuses. The investigation led to the passage of the Public Utility Holding Company Act of 1935 (PUHCA), which mandated that the operations of each affected holding company be limited to a single integrated public utility system. Between 1935 and 1950, more than 750 utilities were spun off from the holding companies. Following the breakup of large holding companies, consolidations continued, but at a much lower annual rate. From 1936 through 1975, there were 517 mergers, occurring at an annual rate of less than 15 a year. Over the past 20 years, 1976 through 1995, 66 mergers have taken place, about 3 per year on average.

In many cases, mergers of electric utilities occurring over the past decade have been different from those that occurred previously. Many of the latest round of mergers- "mega-mergers" as they are sometimes called-combine large companies (Table 8). For example, in 1988 the Southern Company acquired Savannah Electric Power, achieving combined assets of $\$ 27.0$ billion. In 1989, the merger of Pacific Power and Light and Utah Power \& Light resulted in centralized management of electric power over a region covering seven States, with assets of $\$ 10.3$ billion. More recently, the 1993 merger of Gulf States Utilities with the Entergy Corporation (a registered holding company) created a company with more than $\$ 22$ billion in assets. CINergy Corporation, the newest registered utility holding company in the United States, is a combination of Cincinnati Gas \& Electric and PSI Resource, with combined assets of $\$ 8.1$ billion. At last count, there were nine mergers pending. When the mergers are completed, each new company will have assets of over $\$ 4.0$ billion, and three of the nine will have assets of over $\$ 10.0$ billion.

Consolidation of IOUs is not necessarily an ominous trend. The structure of the industry varies greatly by State and region, and in some regions it is fragmented. In parts of the Midwest, a single large IOU serves millions of consumers in several States, while in parts of New England, several tiny IOUs serve portions of a single small State. One school of thought holds that in locations where fragmentation and overlapping service exist, consolidation would improve the efficiency of companies. ${ }^{210}$ Utility executives seeking approval of mergers adopt this line of thinking, claiming that by combining resources significant costs saving will be realized. Executives from Baltimore Gas \& Electric and Potomac Electric Power Company claim that by merging, many duplicate efforts will be eliminated, the work force will be reduced by about 10 percent, and they will save $\$ 1.3$ billion over about 10 years. ${ }^{211}$ Similarly, Union Electric and Central Illinois Public Service plan on saving $\$ 570$ million in 10 years by trimming duplicate corporate and administrative programs, reducing production costs, and cutting about 300 jobs through attrition. ${ }^{212}$ Northern States Power and Wisconsin Energy Corporation estimate that they will realize $\$ 200$ million in annual savings, mostly from reductions in staff. ${ }^{213}$ In every recent announcement, cost savings are cited as the most important reason for merging, and the biggest source of savings is the consolidation of duplicate personnel and facilities in the unmerged companies.

Critics claim that savings from mergers are overstated, and that only small cost reductions ever materialize. A quick look at two mergers occurring in 1992 indicates that this criticism is sometimes but not always accurate. In the 2 years following the merger of Iowa Power and Iowa Public Service, O\&M costs of the merged company increased from about $\$ 28$ per megawatthour (MWh) to over $\$ 30$ per MWh (Figure 19). Employment in the years following the merger decreased slightly, but salaries and wages rose by about 18 percent. Part of the reason for the increase in costs was a reduction in electricity sales for the merged company, without a proportional decrease in total O\&M expenses. Electricity sales went from 13.9 million MWh in 1992 to 12.1 million MWh in 1994, a decrease of

\footnotetext{
${ }^{208}$ This discussion refers to a merger or acquisition of corporations in the same line of business-horizontal merger or acquisition. Vertical mergers or acquisitions, which combine companies of different product lines, are not discussed, although this type of merger occurs frequently in the United States.

${ }^{209}$ Information on mergers from 1936 through 1985 were obtained from the National Regulatory Research Institute, "Electric Utility Mergers and Regulatory Policy," Occasional Paper \#16 (June 1992).

${ }^{210}$ R. Pierce, "Antitrust Policy in the New Electricity Industry," Energy Law Journal (1996), pp. 29-58.

211 "PEPCO to Merge With Baltimore Gas \& Electric," The Washington Post (October 1995).

212 "Utilities' Merger Creates Another Power House," Chicago Tribune (August 15, 1995).

${ }^{213}$ R. Michaels, "Electric Utility Mergers: The Wrong Strategy at the Wrong Time," The Electricity Joumal (January/February 1996).
} 
Table 8. Mergers and Acquisitions of Investor-Owned Utilities, 1986-1995

\begin{tabular}{|c|c|c|c|}
\hline $\begin{array}{l}\text { Merger Partner or } \\
\text { Accuiring Utility }\end{array}$ & $\begin{array}{c}\text { Merger Partner or } \\
\text { Utility Being Acquired }\end{array}$ & $\begin{array}{c}\text { Name of } \\
\text { New Company }\end{array}$ & $\begin{array}{c}1994 \\
\begin{array}{c}\text { Combined Assets } \\
\text { (Billion Dollars) }\end{array} \\
\end{array}$ \\
\hline \multicolumn{4}{|l|}{1986} \\
\hline \multicolumn{2}{|c|}{ Lynches River Electric Coop ....... Heath Springs Light and Power } & - & Unknown \\
\hline \multicolumn{2}{|c|}{ Northern States Power (MN) ...... Home Light and Power Co. (MN) } & .- & 5.6 \\
\hline \multicolumn{2}{|c|}{ Public Service Co. of Colorado ..... Home Light and Power Co. (CO.) } & -- & 4.3 \\
\hline \multicolumn{2}{|c|}{ Northern States Power Co. (WI) . . . L Lake Superior District Power Co. (CO) } & -- & 0.8 \\
\hline \multicolumn{2}{|c|}{ Consolidated Edison Co. of N.Y. . . Lawrence Park Heat, Light, \& Power Co. } & - & 14.2 \\
\hline \multicolumn{2}{|c|}{ lowa-Illinois Gas and Electric Co. ... Sherrard Power Systems } & -- & 1.5 \\
\hline \multicolumn{2}{|c|}{ PacificCorp . . . . . . . . . . . Svilar Light \& Power Co.,Inc. } & -- & Unknown \\
\hline \multicolumn{2}{|c|}{ Cleveland Electric Illuminating ..... Toledo Edison } & Centerior $^{b}$ & 10.7 \\
\hline \multicolumn{4}{|l|}{1987} \\
\hline \multicolumn{2}{|c|}{ Pennsylvania Electric Co. ......... Elkland Electric Co. } & -- & 2.4 \\
\hline \multicolumn{2}{|c|}{ The City of Troy, MT. . . . . . . . . Montana Light and Power } & -- & Unknown \\
\hline \multicolumn{2}{|r|}{ Stonington \& Deer Isle Power Co. } & -- & 0.4 \\
\hline \multirow[t]{2}{*}{ UtiliCorp United } & West Virginia Power & -- & 3.1 \\
\hline & West Kootenay Power \& Light & - & \\
\hline \multicolumn{4}{|l|}{1988} \\
\hline \multicolumn{2}{|c|}{ Appalachian Power Co. $\ldots \ldots \ldots$. Chesapeake Light \& Power Co. } & -- & 3.7 \\
\hline \multicolumn{2}{|c|}{ Monongahela Power Co. ........ Preston Electric Co. } & -- & 1.5 \\
\hline \multicolumn{2}{|c|}{ Duke Power ${ }^{b} \ldots \ldots \ldots \ldots \ldots \ldots$ Nantahala Power \& Light } & -- & 12.9 \\
\hline \multicolumn{2}{|c|}{ Southern Co. ${ }^{a} \ldots \ldots \ldots \ldots \ldots$ Savannah Electric \& Power } & - & 27.0 \\
\hline \multicolumn{4}{|l|}{1989} \\
\hline \multicolumn{2}{|c|}{ Sheraton Valley Electric Coop. . . . . Albia Light and Railway Co. } & -- & Unknown \\
\hline \multicolumn{2}{|c|}{ PacificCorp $\ldots \ldots \ldots \ldots \ldots \ldots$ Utah Power \& Light } & - & 10.3 \\
\hline \multicolumn{4}{|l|}{1990} \\
\hline \multicolumn{2}{|c|}{ Central Vermont Public Service ... . Allied Power \& Light } & -- & 0.5 \\
\hline \multicolumn{2}{|c|}{ Eastern Utilities ${ }^{a} \ldots \ldots \ldots \ldots \ldots$ Newport Electric Corp. } & - & 1.2 \\
\hline \multicolumn{4}{|l|}{1991} \\
\hline \multicolumn{2}{|c|}{ UtiliCorp United .............. Centel Corporation } & -- & 3.1 \\
\hline \multicolumn{2}{|c|}{ Kentucky Utilities Co. $\ldots \ldots \ldots \ldots$. Old Dominion Power Co. } & - & 1.7 \\
\hline \multicolumn{4}{|l|}{1992} \\
\hline Connecticut Light and Power $\mathrm{C}$ & Fletcher Electric Light Co. & -- & 6.2 \\
\hline lowa Public Service Co. ..... & lowa Power Co. & MidWest Power ${ }^{b}$ & 2.6 \\
\hline Kansas Power and Light Co. . & Kansas Gas \& Electric & Western Resources ${ }^{b}$ & 5.2 \\
\hline Indiana Michigan Power Co. . & Michigan Power Co. & - & 4.3 \\
\hline Unitil Corp. ${ }^{a}$. & Fitchburg Gas \& Electric Co. & - & 0.2 \\
\hline NorthEast Utilities ${ }^{a} \ldots \ldots \ldots$ & Public Service of New Hampshire & -- & 10.6 \\
\hline
\end{tabular}

See notes at end of table. 
Table 8. Mergers and Acquisitions of Investor-Owned Utilities, 1986-1995 (Continued)

\begin{tabular}{|c|c|c|c|}
\hline $\begin{array}{l}\text { Merger Partner or } \\
\text { Acquiring Utility }\end{array}$ & $\begin{array}{c}\text { Merger Partner or } \\
\text { Utility Being Acquired }\end{array}$ & $\begin{array}{c}\text { Name of } \\
\text { New Company }\end{array}$ & $\begin{array}{c}1994 \\
\text { Combined Assets } \\
\text { (Billion Dollars) } \\
\end{array}$ \\
\hline \multicolumn{4}{|l|}{1993} \\
\hline Citizens Utilities Co. & Franklin ElectricLight Co. & -- & 3.4 \\
\hline IES Utilities Inc. & $\begin{array}{l}\text { lowa Electric Light and Power Co. } \\
\text { lowa Southern Utilities Co. }\end{array}$ & IES Industries ${ }^{b}$ & 1.8 \\
\hline Texas Utilities $^{b}$ & Southwestern Electric Service Co. & -- & 20.9 \\
\hline Entergy Corp. ${ }^{a} \ldots \ldots \ldots \ldots \ldots$ & Gulf State Utilities & - & 22.6 \\
\hline \multicolumn{4}{|l|}{1994} \\
\hline PSI Resources... & Cincinnati Gas \& Electric & CINergy Corporation ${ }^{b}$ & 8.1 \\
\hline \multicolumn{4}{|l|}{1995} \\
\hline City of Groton, CT ..... & Bozrah Light and Power & -- & Unknown \\
\hline Delmarva Power and Light ... & Conowingo Power Co. & - & 2.7 \\
\hline MidWest Power Systems ....... & lowa-Illinois Gas and Electric & MidAmerican Energy Co. & 4.4 \\
\hline \multicolumn{4}{|l|}{ Pending Mergers ${ }^{c}$} \\
\hline UtiliCorp United ... & Kansas City Power \& Light & Maxim Energies & 5.9 \\
\hline \multirow[t]{2}{*}{ WPL Holding ${ }^{b}$} & IES Industries(b) & Interstate Energy Corp. & 4.3 \\
\hline & Interstate Power Co. & & \\
\hline Puget Sound Power \& Light & Washington Energy Co. & Puget Sound Energy & 4.5 \\
\hline Baltimore Gas \& Electric $^{b}$ & Potomac Electric Power & Constellation Energy Corp. & 13.4 \\
\hline PS of Colorado ${ }^{b}$. & Southwestern PS & New Century Energies & 6.0 \\
\hline Ohio Edison Company & Centerior Energy Corporation & FirstEnergy Corporation & 19.5 \\
\hline Atlantic Energy, Inc. $\ldots \ldots \ldots \ldots$ & Delmarva Power and Light Company & Unknown & 5.1 \\
\hline Union Electric Company & CIPSCO, Inc. & Ameren Corporation & 8.4 \\
\hline Northern States Power Company .. & Wisconsin Energy Corporation & Primergy Corporation & 10.4 \\
\hline New England Electric System ${ }^{a} \ldots \ldots$ & Nantucket Electric & - & \\
\hline
\end{tabular}

${ }^{2}$ Holding Company Registered under the Public Utility Holding Company Act of 1935.

${ }^{b}$ Holding Company exempt from the Public Utility Holding Company Act of 1935. MidAmerican Energy requested permission to reorganize into a holding company.

The status of these mergers is unknown. As of April 1996, Primergy Corp. and New Century Energies have filed with the SEC for holding company status. MidAmerican Energy Co. requested FERC's approval to reorganize into a holding company.

${ }^{d}$ Combined assets unknown. New England Electric System's net utility plant assets are $\$ 3.7$ billion. Nantucket is a small company serving about 9,000 customers.

-- = No new company was established as a result of this merger.

Note: This table does not include acquisitions of other energy companies (i.e., natural gas or power marketers) by investor-owned electric utilities.

Sources: Energy Information Administration, Financial Statistics of Major U.S. Investor-Owned Electric Utiities 1995, DOE/EIA0437(95/1) (Washington DC, December 1996); Public Power Annual Statistical Issue, Getting Big (January-February 1996), p. 10; M. Frankena, "Electric Utility Mergers: Trends \& Antitust Update," paper presented at the Institute of Public Utilities Annual Conference (December 12, 1995); U.S. Securities and Exchange Commission, Financial and Corporate Report: Holding Companies Registered Under the Public Utility Holding Company Act of 1935 as of October 1, 1995 (Washington, DC); U.S. Securities and Exchange Commission, Financial and Corporate Report: Holding Companies Exempt from thePublic Utility Holding Company Act of 1935 as of August 1, 1995 (Washington, DC); Edison Electric Institute, Catalogue of Investor-Owned Electric Utilities, 35th Edition (1995); and various articles in trade journals and newspapers. 
Figure 19. Comparison of Costs Before and After Merger of lowa Power and lowa Public Service

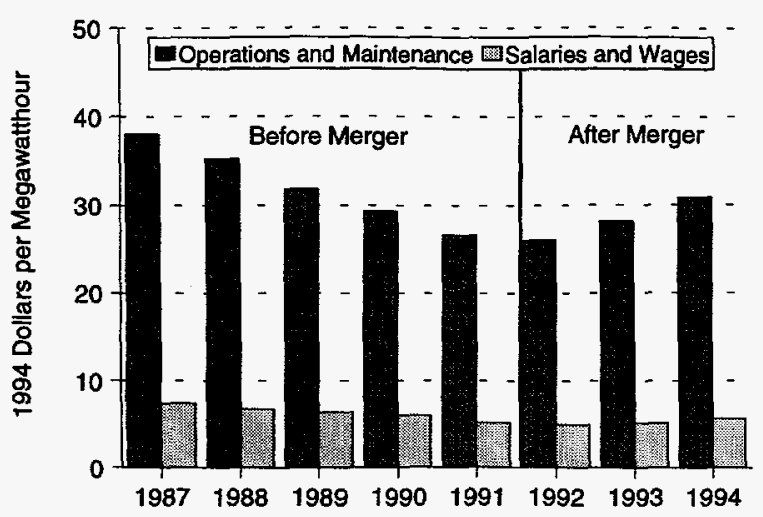

Note: Companies merged in 1992.The new name is Midwest Power.

Source: Energy Information Administration, Financial Statistics of Major U.S. Investor-Owned Utilities 1994, DOE/EIA0437(94/1) (Washington, DC, December 1995), and previous issues.

about 13 percent. For the short term, this merger did not produce any costs savings.

In comparison, the merger of Kansas Power \& Light and Kansas Gas \& Electric had different results. In the 2 years following the merger, electricity sales for the merged companies increased by 11 percent, while total O\&M expenses remained approximately the same. The result was a decrease of $\$ 3.00$ per $M W h$, or 11 percent, in real O\&M costs over the 2 years following the merger (Figure 20). More information is needed to conclude that the merger caused the reduction in costs, but it probably helped, which is an encouraging sign for advocates of utility mergers.

Cost reduction is not the only reason for companies to merge. A merger of two vertically integrated utilities may result in the consolidation of transmission networks, which enables one firm to control the facilities over which regional power supplies must flow. For example, Union Electric's acquisition of Central Illinois Public Service will result in ownership and control by one company of interconnections with 28 other utility systems from southwest Oklahoma to Chicago and eastward to the Tennessee Valley Authority and Ohio. Even with mandated
Figure 20. Comparison of Costs Before and After Merger of Kansas P\&L and Kansas G\&E

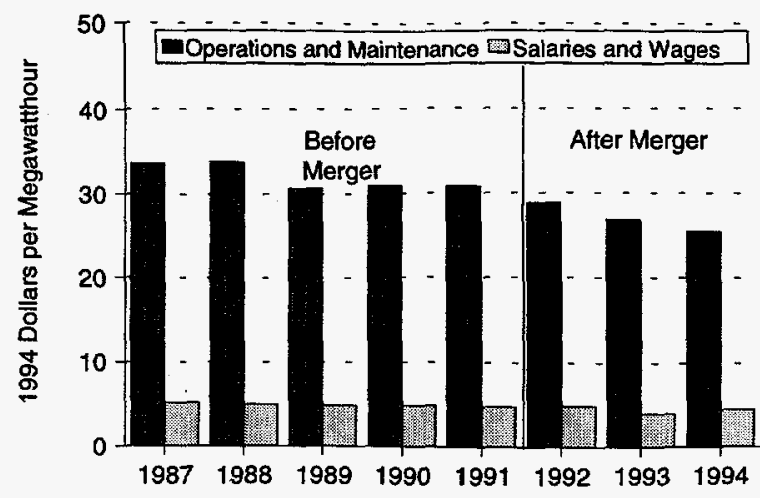

Note: Companies merged in 1992. Kansas P\&L changed its name to Western Resources.

Source: Energy Information Administration, Financial Statistics of Major U.S. Investor-Owned Utilities 1994, DOE/EIA0437(94/1) (Washington, DC, December 1995), and previous issues.

open access to the transmission lines, some analysts believe that the owner of the lines can affect the relative success of rival generators and that ownership will increase the strategic position of the company in dealing with competitors. ${ }^{214}$

This issue and others related to mergers of IOUs are being discussed throughout the industry, and FERC is examining its criteria and policies for evaluating mergers in light of the changing industry. Many analysts have suggested that the merger guidelines used by the Department of Justice (DOJ) and the Federal Trade Commission (FTC) should be used by the FERC to evaluate the affects of mergers on competition in the industry. ${ }^{215}$ These guidelines recommend that first the relevant product and geographic markets be defined, and then the concentration within those markets be measured to determine the proposed merger's affect on competition. DOJ and FTC evaluate competition using the HirfindahlHirschman Index (HHI), a statistical technique that quantifies concentration of market shares in a given industry. The HHI reflects the idea that possession of large shares of concentrated markets creates opportunities for price leadership and for unilateral reductions in output that boost prices above competitive levels.

\footnotetext{
${ }^{214} \mathrm{~J}$. Wilson, "Merger Policy Guidelines for the Electric Power Industry," The Electricity Journal (January/February 1996), p. 15.

215 "Horizontal Merger Guidelines of 1992," Department of Justice and the Federal Trade Commission.
} 


\section{Investor-Owned Utility Diversification Activities}

Diversification is another business strategy that electric utilities are using to remain viable. Investments in nonutility businesses have been a feature of the electric utility industry for decades. There have been four phases of utility diversification over the past 20 years. ${ }^{216}$ Vertical integration, primarily into mining and oil and gas exploration and development were the initial diversification areas. Some of these were justified by the need for guaranteed fuel supplies and prices for power plants. The next phase was acquisition of entities engaged in activities outside of the core business. This kind of diversification was practiced by most major industry segments. The results were mixed-some were successful while others failed. The late 1980s saw a retrenching of the utility industry, with a leveling off in the number of new ventures.

More recently, with changing regulatory constraints and increased competition, electric utilities are investing more aggressively in nonutility businesses. The increase in ownership of nonutility subsidiaries by electric utilities in the past few years has been significant. From 1992 through 1994, registered electric utility holding companies increased their ownership of nonutility businesses from 95 companies to 160 companies, an increase of almost 70 percent in 3 years (Table 9). Exempt holding companies show a similar pattern. In 1992, 72 exempt electric holding companies owned 1,661 nonutility subsidiaries. By 1994, exempt holding companies owned 1,954 nonutility businesses. ${ }^{217}$

Some of the largest companies in the electric power industry are expanding their investments to energy service companies, to cogeneration and independent power production, to oil and gas exploration, development, and production, and to foreign utility ventures. Since about 1990, much of the growth in diversification has come from international ventures. Numerous utilities are taking advantage of worldwide trends in privatization and restructuring to enter foreign electric utility markets. The Energy Policy Act of 1992 (EPACT) provided a boost to international investments by lifting some of the restrictions imposed by PUHCA. In particular, it allowed holding companies to purchase interests in foreign utility companies (FUCOs). It also lifted restrictions on holding companies' purchases of cogeneration facilities and exempt wholesale generators (EWGs). Many companies are taking advantage of these opportunities. By the end of 1994, electric utility holding companies had invested over $\$ 5$ billion in EWGs and FUCOs, representing slightly more than 1 percent of their assets (Table 10).

Other areas of opportunity have arisen recently for electric utilities. The 1996 Telecommunications Act allows the

Table 9. Number of Nonutility Subsidiary Companies Owned by Electric Utility Holding Companies, 1986-1994

\begin{tabular}{|c|c|c|c|c|}
\hline \multirow[b]{2}{*}{ Year } & \multicolumn{2}{|c|}{$\begin{array}{l}\text { Registered Electric } \\
\text { Utility Holding Companies }\end{array}$} & \multicolumn{2}{|c|}{$\begin{array}{c}\text { Exempt Electric Utility } \\
\text { Holding Companies }\end{array}$} \\
\hline & $\begin{array}{c}\text { Number of } \\
\text { Electric Utilities }\end{array}$ & $\begin{array}{l}\text { Number of } \\
\text { Nonutility Subsidiaries }\end{array}$ & $\begin{array}{c}\text { Number of } \\
\text { Electric Utilities }\end{array}$ & $\begin{array}{c}\text { Number of } \\
\text { Nonutility Subsidiaries }\end{array}$ \\
\hline $1986 \ldots \ldots \ldots \ldots \ldots$ & 10 & 47 & 52 & 515 \\
\hline $1987 \ldots \ldots \ldots \ldots \ldots$ & 10 & 51 & -- & -- \\
\hline $1990 \ldots \ldots \ldots \ldots$ & 10 & 64 & 71 & 1,630 \\
\hline $1991 \ldots \ldots \ldots \ldots$ & 10 & 67 & - & -- \\
\hline $1992 \ldots \ldots \ldots \ldots \ldots$ & 10 & 95 & 72 & 1,661 \\
\hline $1993 \ldots \ldots \ldots \ldots$ & 11 & 116 & -- & - \\
\hline $1994 \ldots \ldots \ldots \ldots$ & 12 & 160 & 69 & 1,954 \\
\hline
\end{tabular}

- = Not available.

Sources: U.S. Securities and Exchange Commission, Financial and Corporate Report, Holding Companies Registered Under the Public Utility Holding Company Act (PUHCA) of 1935 as of October 1, 1995, and Holding Companies Exempt From the PUHCA as of August 1, 1995 (Washington, DC).

\footnotetext{
${ }^{216}$ Edison Electric Institute, Nonutility Business Activities of Investor-Owned Utilities (Washington, DC, 1994). available.

${ }^{217}$ Analysis of the changes in nonutility assets would be a better indication of diversification; however, a time series showing nonutility assets is not
} 
Table 10. Investments in Exempt Wholesale Generators and Foreign Utilities in 1994

\begin{tabular}{l|c|c|c|c}
\hline & \multirow{2}{*}{$\begin{array}{c}\text { No. of } \\
\text { Companies }\end{array}$} & $\begin{array}{c}\text { Consolidated } \\
\text { Assets } \\
\text { (million dollars) }\end{array}$ & \multicolumn{2}{|c|}{ Investments in EWGs \& FUCOs } \\
\cline { 5 - 6 } & Million Dollars & Percent \\
\hline Exempt Electric Utility Holding Companies $\ldots \ldots \ldots$ & 69 & 288,603 & 3,785 & 1.3 \\
Registered Electric Utility Holding Companies ......... & 12 & 117.210 & 1.702 & 1.5 \\
\hline
\end{tabular}

EWGs = Exempt Wholesale Generators.

FUCOs = Foreign Utility Companies.

Sources: U.S. Securities and Exchange Commission, Financial and Corporate Report, Holding Companies Registered Under the Public Utility Holding Company Act (PUHCA) of 1935 as of October 1, 1995, and Holding Companies Exempt From the PUHCA as of August 1, 1995 (Washington, DC).

Federal Communications Commission (FCC) to approve telecommunications ventures owned by utility holding companies after a 60-day review. Previously, such investments were restricted by PUHCA, and applications were subject to lengthy review by the Securities and Exchange Commission. The Entergy Corporation became the first electric utility to receive an "exempt telecommunications company" (ETC) designation from the FCC under the Telecommunications Act. Entergy Technology Company, a subsidiary of the Entergy Corporation, will sell excess capacity from its network to long-haul telephone companies. Units of the Southern Company, Northeast Utilities, and Allegheny Power have formally filed for ETC status and are awaiting rulings. ${ }^{218}$ On the down side, investment in the telecommunications business may be risky for electric utilities. They have little experience in the field, as compared to phone companies, and they will have to build the business from scratch. In the new competitive environment, however, some IOUs see diversification into a growing field like telecommunications as an opportunity to grow. On the other hand, diversification into nonutility businesses does not guarantee that the company will prosper. There are risks involved, and diversification may distract attention from the main activities of the company. Some utilities have given up on nonutility business ventures and have decided to invest in other utility and energy-related businesses.

Finally, the term "Btu supplier" may be only a buzz word, but it also may signify a serious movement by electric utilities to enter the natural gas business. For example, Texas Utilities (TU) will acquire the gas distribution, gas pipeline, and independent power subsidiaries of Enserch Corporation. The gas distribution unit TU is acquiring, Lone Star Gas, is the largest in Texas, serving over 1.3 million customers, including many of the customers served by TU's two electric units. TU officials claim signi- ficant savings and other benefits from this acquisition. Houston Industries will acquire NorAm Energy Corporation, a gas distribution, gas pipeline, and marketing company. The company claims, and industry observers agree, that this acquisition will give the company additional marketing skills and customer access to help it thrive in a deregulated environment. These are a few examples of electric utilities expanding into the natural gas business. Other companies are doing or at least thinking about doing the same. Mergers of electric utilities and gas companies are not new; there are numerous integrated gas and electricity utilities in existence today. On the other hand, competitive pressures may make mergers more attractive to utilities that have not, as yet, expanded into other energy fields.

\section{Corporate Reorganization Activities}

Many IOUs have reorganized their corporate structures or plan to reorganize them in the near future. Reorganization of the corporate structure can take many forms, such as creating new divisions within the company to focus on important functions, combining resources or functions to improve efficiency, or creating a subsidiary company to focus on new business opportunities. Although FERC Order 888 does not require changes in corporate structures, many are choosing to reorganize, perhaps in part to prepare for FERC's open transmission access requirements and for a different regulatory environment. For example, Pacific Gas \& Electric (PG\&E) has established a new generation business unit that will operate all of the generating plants owned by the utility in its Northern and Central California service territory. It also formed a separate transmission business unit to operate its highvoltage transmission system throughout the service territory. With this separation of functions, PG\&E believes that they are in a better position to respond competitively.

218 “C\&SW and Entergy Affiliates Win 'ETC' Status Under Telecommunications Act," Electric Utility Week (April 22, 1996), p. 2. 
Another reason for corporate reorganization is to give more attention to customer needs. To remain competitive in today's business environment and to endure in the future, firms must address and achieve customer satisfaction. More competition requires utilities to provide new products and better service and, in general, to give more attention to customer needs. Many companies are creating units within their organizations to focus on improving customer relations and services.

In general, corporate reorganization, in one form or another, is happening throughout the industry, and it is expected to continue as IOUs look to become more efficient and more flexible in a restructured industry.

\section{Publicly Owned Utilities and Cooperatives}

Publicly owned utilities (municipal, Federal, State, and other government owned utilities) and rural electric cooperatives make up a much smaller share of electric sales than the vertically integrated IOUs. In 1994, publicly owned utilities and cooperatives accounted for a combined 14 percent of retail electricity sales, compared with 76 percent for IOUs. Although relatively small in comparison to IOUs, publicly owned utilities and cooperatives will be affected by restructuring of wholesale markets. Publicly owned utilities and cooperatives with generation facilities (most of these utilities do not have generation or transmission facilities--they are distribution utilities only) may want to expand electricity sales into other markets, and they will need access to transmission lines at a competitive price. On the other hand, they may face competition from other utilities or power marketers seeking to sell electricity in their markets. With open transmission access, publicly owned utilities that only distribute power will have more opportunity to purchase lower priced electricity from companies other than their normal suppliers. Thus, they have a stake in the outcome of deregulation.

\section{Publicly Owned Utility Activities}

In 1994, major publicly owned utilities with generating capacity, excluding Federal utilities, had $\$ 23$ billion in revenues, most of which went to pay for O\&M expenses (Figure 21). About 15 percent of their revenues went for fuel purchases and less than 4 percent for taxes. (Publicly
Figure 21. Allocation of Revenue Dollars from Electric Operations for Publicly Owned Generator Utilities, 1994

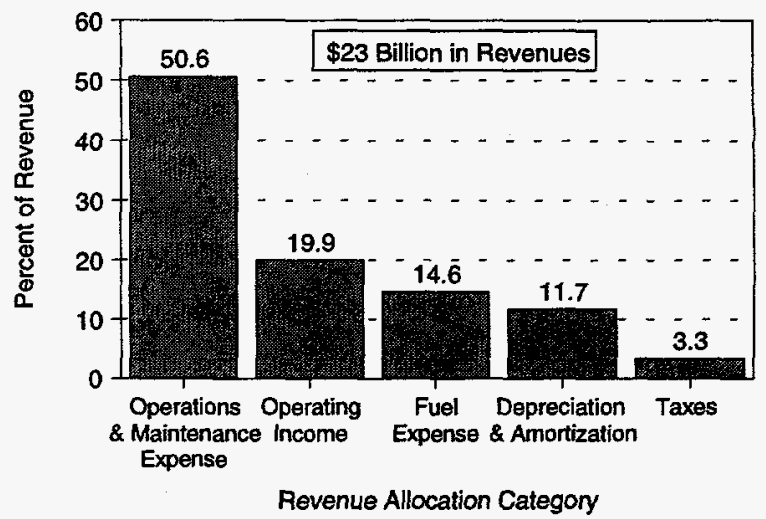

Note: Totals may not equal sum of components due to independent rounding.

Source: Energy Information Administration, Financial Statistics of Major U.S. Publicly Owned Electric Utilities 1994, DOE/EIA-0437(94/2) (Washington, DC, December 1995).

owned utilities are exempt from most taxes.) In 1994, generator utilities' O\&M expenses were $\$ 15$ billion, of which 39 percent went toward power production and 37 percent toward power purchases (Figure 22). Publicly owned utilities rely on power purchases to a greater extent than do IOUs to meet their requirements for power, and federally owned Power Marketing Administrations (PMAs) are a source of relatively low-cost power for many of them. By law, PMAs are required to give priority in power sales to "preference customers," which include public utility districts, municipalities, and customerowned cooperatives. While publicly owned utilities may have some competitive advantage over IOUs as a result of tax exemptions and access to low-cost power from PMAs, they still must keep their costs down to stay competitive in the restructured industry. From 1989 through 1994 their average O\&M costs were lower than those of IOUs, and if this trend continues, they will be in a relatively favorable competitive position. Real O\&M costs for publicly owned utilities went from 3.5 cents per $\mathrm{kWh}$ in 1989 to about 3.3 cents per kWh in 1994 (Figure 23), ${ }^{219}$ as lower fuel costs helped reduce O\&M expenses.

Unlike IOUs, publicly owned utilities in general have not joined the merger trend. In 1986 there were 1,991 nonFederal publicly owned utilities, which accounted for

\footnotetext{
${ }^{219}$ Costs are for over 200 major publicly owned generator electric utilities reported in Energy Information Administration, Financial Statistics of Major U.S. Publicly Owned Electric Utilities 1994, DOE/EIA-0437(94/2) (Washington, DC, December 1995).
} 
Figure 22. Allocation of Electric Operation and Maintenance Expenses for Publicly Owned Generator Utilities, 1994

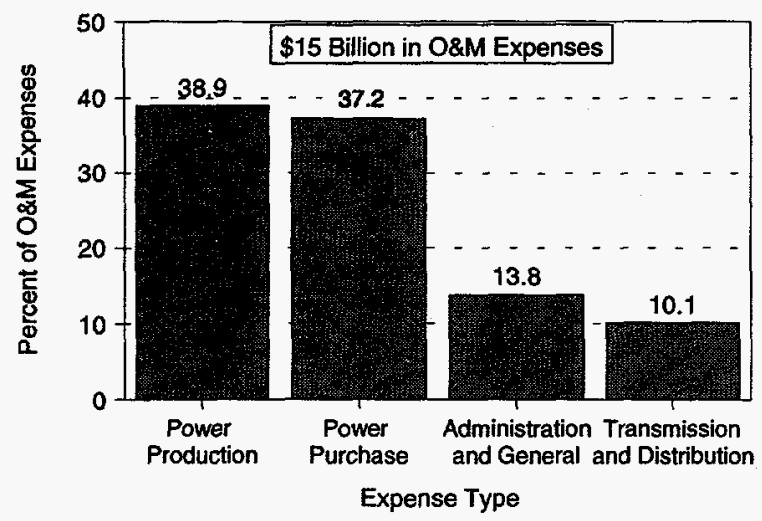

Source: Energy Information Administration, Financial Statistics of Major U.S. Publicly Owned Electric Utilities 1994, DOE/EIA-0437(94/2) (Washington, DC, December 1995).

about 15 percent of total industry sales. In 1994 there were 2,005 non-Federal, publicly owned utilities, accounting for 14 percent of total industry sales. The incentives for publicly owned utilities to merge are not as great as those for IOUs. Most publicly owned utilities do not have generation facilities, and gains in production efficiency from a merger are not an issue. In situations where efficiency is an issue, publicly owned utilities traditionally have formed alliances or "mutual aid" programs, such as joint equipment-purchasing programs. They also have gone the route of joint-action programs, which capture some of the same efficiencies as a merger. ${ }^{220}$ In general, publicly owned utilities are more likely to compete by controlling internal costs and sharing services.

Many publicly owned utilities are concerned that mergers of IOUs in their regions will create excess market power. Some of them have publicly voiced their objections to the FERC. For example, public utility officials in Illinois and Missouri have asked the FERC to require Union Electric and Central Mllinois Public Service to form an independent system operator (ISO) to mitigate the market power that the utilities would have if they were allowed to merge. They claim that comparable transmission service cannot be achieved if the merging utilities are free to administer their tariffs. In another case, affected publicly owned utilities and cooperatives told FERC that the proposed three-utility Interstate Energy merger proposal is anticom petitive and should be either rejected or set for hearing.

The publicly owned utilities and cooperatives claimed that the merger plans failed to include plans for an ISO.
Figure 23. Operation and Maintenance Expenses for Publicly Owned Electric Utilities, 1989-1994

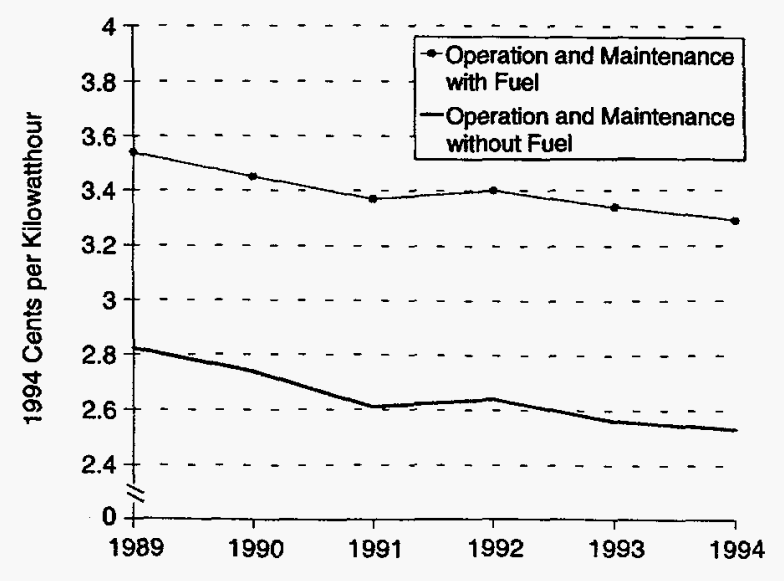

Note: Includes only Public Utilities with generators.

Source: Energy Information Administration, Financial Statistics of Major U.S. Publicly Owned Electric Utilities 1994, DOE/EIA-0437(94/2) (Washington, DC, December 1995).

Also, it is believed by some publicly owned utilities that even a fully effective comparable transmission tariff will not eliminate excess market power in generation. With the increase in merger activity of IOUs, publicly owned utilities believe that an appropriate merger policy is essential to prevent unnecessary consolidation of IOU generation capacity.

\section{Rural Electric Cooperative Activities}

Rural electric cooperatives (RECs), which provide electricity to sparsely populated areas, are an important segment of the industry. Currently, 939 RECs in 46 States are serving approximately 30 million customers. Most of them distribute electricity only, and are owned by the customers they serve. Distribution cooperatives engage primarily in local distribution and sale of electricity, depending on the transmission lines of neighboring utilities-often IOUs-to obtain power. Cooperatives sometimes have large customers within easy reach of an IOU's transmission facilities, and they are concerned about retaining such customers in a more competitive environment.

Recognizing the problems inherent in relying on outside sources for power supply, many distribution cooperatives distribution cooperatives are bound to each other by both ownership and contract. 
It is difficult to generalize about the reactions of G\&Ts to restructuring. Some are very competitive power supply providers for their cooperative members. Others have invested in high-cost generation facilities (in many cases, the same high-cost units for which IOUs are now seeking recovery of stranded costs) and are burdened with highcost power, making them uncompetitive. Cajun Electric Power Cooperative, one of the larger G\&Ts, is an example of a cooperative that is not competitive in today's industry. Cajun invested in a minority share of the River Bend Nuclear Plant built by Gulf States Utilities Company. The project had huge cost overruns, which Cajun could not pass through in customer rates, causing the cooperative to file for bankruptcy. Vermont Electric Cooperative (VEC) is another example of a company that is not competitive in today's electricity market. Similar to Cajun's situation, VEC's investments in nuclear power were declared imprudent by the Public Service Board (PSB) of Vermont, and recovery of the costs was disallowed. The PSB also rejected a debt payment plan for $\$ 115$ million in defaulted loans, reasoning that because of increasing competition, the plan would not be economically viable over the long term.

In contrast, Oglethorpe Power Corporation, the largest power supply cooperative in the United States, has taken many steps to stay competitive. .21 $^{221}$ Through a cost management program, Oglethorpe has reduced labor costs by 32 percent over recent years and has avoided cost increases despite placing over $\$ 900$ million of electrical plant in service. In January 1996, Oglethorpe signed a 4month agreement with Enron Power Marketing, Inc., to provide the full power needs of its 39 member systems. According to Oglethorpe, this short-term deal saved the company several million dollars. Oglethorpe has since extended the power purchase agreement with Enron for 4 months and is working to finalize a long-term arrangement with one or more power marketers that, Oglethorpe believes, will produce cost savings for its member systems. Oglethorpe, although not necessarily representative of all G\&Ts, is an example of a company improving its internal operations and procedures to remain competitive.

Some cooperatives are looking to mergers to stay competitive, although not to the same extent as IOUs. Two Kansas cooperatives plan to combine their companies in January 1997, with expected savings of $\$ 2.8$ million over 10 years. Two North Dakota cooperatives have agreed to a merger that will save an estimated $\$ 9.4$ million in administrative and operation costs over 10 years. In the near future, more cooperatives may recognize the importance of economies of scale and shared resources in the new competitive era. Where significant costs savings can be realized, it is reasonable to expect that more mergers will be announced.

\section{Power Marketers}

Power marketers are a relatively new type of firm in the electric power industry. They are different from traditional electric utilities. A power marketer buys electric energy and transmission and other services from traditional utilities, or other suppliers, and then resells these products. The concept of a power marketer first appeared in the mid-1980s. In October 1985, Citizens Energy filed a petition with the FERC seeking approval to purchase and resell electricity. This company was the first to file such a petition. In July 1987, the second petition to buy and resell electrical power was filed with the FERC by Howell Gas Management. It was not until August 1989, however, that the FERC approved a petition granting the right to buy and resell electric power to Citizens Power and Light. ${ }^{222}$ This order was particularly significant because the FERC recognized the existence of a new type of company in the wholesale marketplace and accepted the market-based rate schedules proposed by Citizens. That approval proved to be the foundation for subsequent applications for power marketing status.

Growth in the wholesale power market-estimated to be around 1,343 billion $\mathrm{kWh}$ in $1994^{223}$-has spurred the increase in power marketing companies. EPACT ${ }^{224}$ and FERC's movement toward increased competition in the wholesale market by allowing market-based rates were also major factors in the increase in power marketers. Since the first approvals for power marketing status were granted, the number of companies obtaining approval has increased substantially. From a total of 9 in 1992, the number had grown to 180 by the end of December 1995. Most of the companies are gas marketers, who see power generation as a potentially lucrative market. Others types of companies getting into the power marketing business include brokers and financial firms, utility affiliates, independent entrepreneurs, commodity traders and manufactures, and independent power producers.

${ }^{221}$ T.D. Kilgore, "Congressional Testimony House Commerce Energy and Power Electricity Regulation," Federal Document Clearing House, Inc. (May $15,1996)$.

${ }^{222}$ Citizens Power \& Light Corp., 48 Federal Energy Regulatory Commission (FERC) 61,210 (August 8, 1989).

${ }^{223}$ Energy Information Administration, Electric Power Annual, Volume II, DOE/EIA-0348(94/2) (Washington, DC, November 1995).

${ }^{224}$ For further information regarding the provisions contained in EPACT, see Chapter 4 of this report. 
Presently, only a relatively small number of power marketers are active in the market, but the number of active companies is growing. In 1994, 9 firms sold 7.2 million MWh. In 1995, 40 power marketers sold 26.6 million MWh of electricity. Three companies-Enron Power Marketing, Lewis Dreyfus, and Electric Clearinghouse-accounted for 57 percent of the sales. ${ }^{225}$

In summary, the growth of power marketers signals the potential for a fundamental change in the wholesale electricity business. Since the late 1980 s the number of companies approved for power marketing has gone from a few to 180 . Presently, only about 10 companies are active in the business of buying and reselling power. It is expected that, as access to transmission lines increases in a competitive environment, more companies will become active in the wholesale electric power business as power marketers.

\section{Spot Markets and New Trading Mechanisms}

Electricity is becoming a commodity like natural gas, petroleum products (e.g., crude oil, heating oil, gasoline), and other energy products. Electricity at wholesale value is now sold at market centers at market-based rates, and wholesale electricity prices are published daily. Two new electricity futures contracts have been introduced, which can help electricity buyers and sellers manage business risk. These events are relatively new, and they mark the beginning of a new era in the electric power industry.

Wholesale electricity spot markets are now operating at several sites in the western United States. The Pacific Northwest/Pacific Southwest AC Intertie transmission facilities between the California-Oregon Border (referred to as COB), and the Palo Verde Nuclear Power Plant highvoltage switchyard in Arizona are two transfer points with spot markets. Wholesale electricity is also traded at five delivery points spanning approximately a 100-mile area in Washington State (referred to collectively as MidColumbia). In Atlanta, Georgia, Continental Power Exchange (CPEX) has started a computerized electricity trading market. According to CPEX, as of March 1996, 30 companies in 28 States across the United States were using the electronic exchange, and CPEX expects the market to grow as the industry becomes more accustomed to electronic trading. The development of market centers for electricity trading is indicative of a change in fundamental business procedures brought about, in part, by restructuring and increased competition in the electric industry.

Public information on prices is necessary for a spot market to function properly. That is, to make informed purchasing decisions, potential electricity buyers need price information on recent transactions. In June 1995, Dow Jones \& Company (DJ) met that need for the western markets by compiling peak and off-peak electricity price indices for non-firm power at the COB. Later, DJ began compiling firm and non-firm price indices on transactions at Palo Verde, and now both the COB and Palo Verde indices are published daily in the Wall Street Journal. DJ also compiles price indices, which are available by subscription, for Mid-Columbia and for the North American Reliability Council regions MAIN and ECAR. CPEX has also recently begun publishing a price index in the Energy Daily for transactions occurring during peak hours on the computerized exchange. The DJ and CPEX price indices should help sustain the growth in trading at these market centers, and as the industry becomes more competitive, spot markets and price indices may develop for other areas of the country.

One of the most interesting development in the industry is the electricity futures contract. On March 29, 1996, The New York Mercantile Exchange (NYMEX) began selling electricity futures contracts for the $\mathrm{COB}$ and Palo Verde markets. NYMEX indicated that the futures contract was designed to service a growing wholesale trade at these market centers. The contract, which is standard for both $\mathrm{COB}$ and Palo Verde, covers $736 \mathrm{MWh}$ delivered over a month (Table 11). July settlement prices at $\mathrm{COB}$ for trading in May 1996 ranged from a low of $\$ 11.35$ to a high of $\$ 12.54$ per MWh. The July settlement prices at Palo Verde were slightly higher. On April 26, 1996, NYMEX introduced electricity options contracts at the $\mathrm{COB}$ and Palo Verde. An option on a future gives the purchasing party the right, but not the obligation, to buy (in the case of a call option) or sell (in the case of a put option) the underlying futures. It can be thought of as a form of insurance against high or low futures prices. The buyer of the option pays the option writer an up-front premium for this insurance.

It is expected that power marketers will initially be the most likely users of the electricity futures. A power marketer entering into a contract to sell power at a predetermined price runs the risk that the price it must 1996).

${ }^{225}$ Edison Electric Institute, Power Marketers Yearbook 1995 (Washington, DC, 1995); and Utility Data Institute, Who's Who in Power Marketing (May 
Table 11. NYMEX Futures Contract

Contract Unit:

736 megawatt hours (MWh) delivered over a month.

Delivery Rate:

2 megawatt (MW) throughout every hour of the delivery period (can be amended).

\section{Delivery Period:}

Sixteen on-peak hours from 0700 prevailing time to 2200 (can be amended by mutal consent).

Termination of Trading:

Trading in the delivery month shall cease on the third business day prior to the first day of the delivery month.

Prices and Price Fluctuations:

Prices shall be quoted in dollars per MWh. The minimum price fluctuation will be 1 cent per MWh. The maximum permissible price will be $\$ 3.00$ per MWh above or below the preceding day's settlement price. Expanded limits will apply when the contract settles at the limit.

\section{Scheduling:}

Buyer and seller must follow Western Systems Coordinating Council scheduling practices.

pay for electricity will increase before the power is delivered. The power marketer can hedge its risk by buying electricity futures that match the quantity and timing of the original power contract (see inset below). Under traditional cost-plus regulation, IOUs may not find these risk-management tools very useful. However, in order to participate in the growing wholesale markets, it is expected that many IOUs will submit applications seeking FERC approval to sell wholesale power at marketbased rates. FERC Order 888 discusses this issue, and it sets the framework for transmission-owning utilities and their affiliates to participate in these markets. Indeed,
FERC's stated goal is to develop more competitive bulk power markets.

\section{Independent System Operators}

ISOs are a new concept in the electric utility industry. Their purpose will be to manage the transmission network in such a way as to allow open and equal access to all electricity buyers and sellers. The FERC does not require utilities to have an ISO in order to ensure open and equal access to the transmission network, but by providing standards for approval, FERC encourages companies and regional power pools to explore the concept. ${ }^{226}$

Questions arise as to what exactly an ISO will do to manage the transmission network, and how decisions will be made. The answers to these questions are being worked out by State commissions and utilities considering this option. It is clear, however, that the ISO will be responsible for reliability and security of the transmission system. The ISO will probably oversee all maintenance, even if the transmission owners provide day-to-day maintenance. The FERC guidelines, noted above, provide some light on other functions of an ISO. They include congestion management, administering transmission and ancillary pricing, making transmission information publicly available, and other activities. It is expected that these functions will not be performed by all ISOs; there will be differences from region to region.

Many proposals to form ISOs have been reported recently in the trade journals. Some applications to form ISOs have been filed with FERC. The California Public Utility Commission's proposal to transfer operational control (but not ownership) of certain transmission facilities to an ISO is perhaps the most visible and publicized ISO plan. Proposals to start ISOs are also being discussed in New York, Wisconsin, Massachusetts, Texas, and numerous other States. Thus, interest in the ISO concept appears to be spreading across the country, and it is expected that many of them will be formed over the next several years.

226 In Order 888, FERC outlined 12 principles an ISO should follow in its management of a transmission network. 


\section{Background Information on Futures Contracts}

Futures contracts are a standardized form of forward contracting that has been practiced for centuries. However, they differ from fonward contracts in that they are standardized and traded on an organized exchange, rather than being the result of negotiations between two parties. These contracts have several key features:

- The buyer of a futures contract is said to be in a "long" position, and agrees to receive delivery of the commodity.

- The seller of a futures contract is said to be in a "short" position, and agrees to make delivery of the commodity.

- The contracts are traded on exchanges either by open outcry in specified trading areas or electronically via a computerized network.

- Futures contracts can be terminated by an offsetting transaction executed at any time prior to the contract's expiration. Most futures contracts are terminated by offsetting transactions.

- The same or similar futures contracts can be traded on more than one exchange in the United States or elsewhere.

If you buy a futures contract (go long) and the price goes up, you profit by the amount of the price increase times the contract size; if you buy and the price goes down, you lose an amount equal to the price decrease times the contract size (Figure 24). If you sell a futures contract (go short) and the price goes down, you profit by the amount of the price decrease times the contract size; if you sell and the price goes up, you lose an amount equal to the price increase times the contract size (Figure 24).

Figure 24. Payoff Diagram for Long and Short Futures Positions

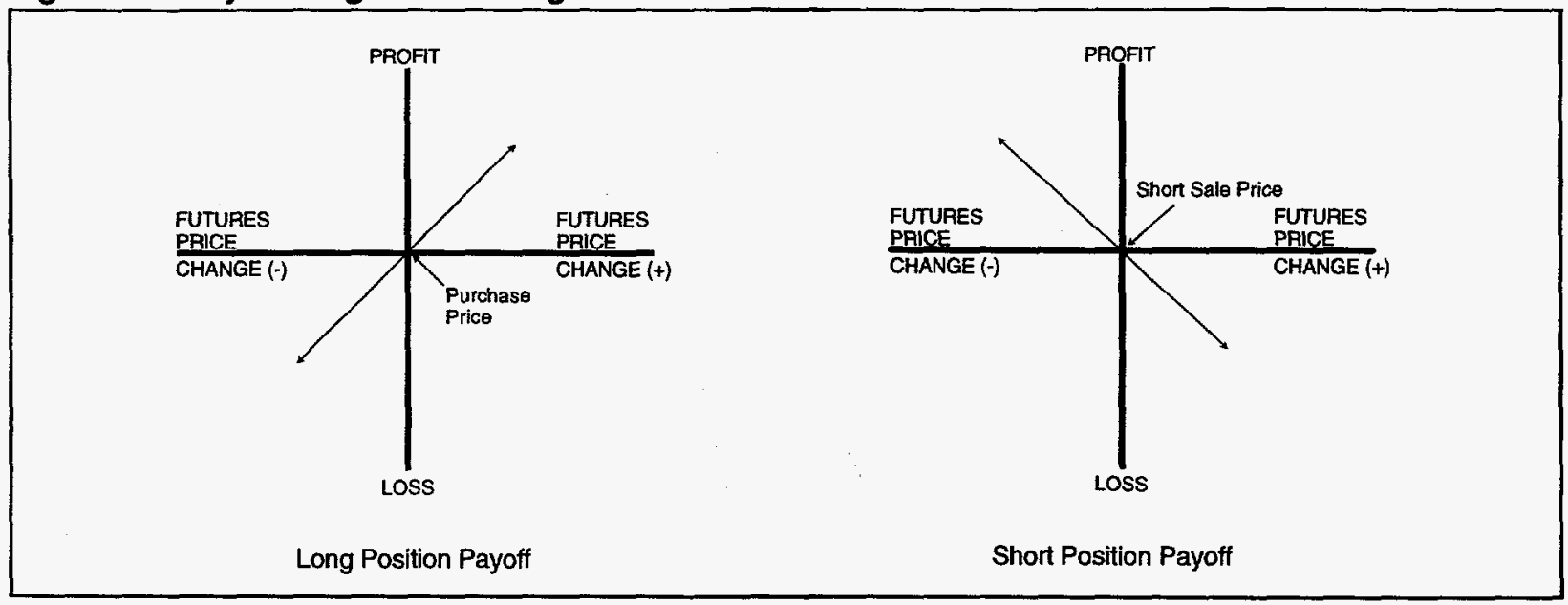

Source: Energy Information Administration, Office of Coal, Nuclear, Electric, and Alternate Fuels.

Options are another type of financial instrument. Option contracts are usually introduced on a commodity after the futures contract is trading successfully. An option is the right, but not the obligation, to buy or sell a specified number of underlying futures contracts or a specified number of commodity, currency, index, or financial instruments at a price agreed upon on or before a given future date. Options on futures are traded on the same exchanges that trade the underlying futures contracts. They can be thought of as a form of insurance against high or low prices. The buyer of the option pays the option writer an up-front premium for this insurance. The major difference between futures and options centers on the obligations of the purchaser and the seller. A futures contract obligates the seller to execute the contract, regardless of whether it is profitable or not. In contrast, a purchased option is a limited-risk instrument because, as noted above, the option purchaser has the right, but not the obligation, to buy or sell the underlying futures contract at the option's strike price. At expiration, an option that is worthless will not be exercised, and the option purchaser's loss is limited to the premium paid to buy the option. 


\section{Background Information on Futures Contracts (Continued)}

Futures markets have evolved and flourished because they serve useful purposes. The two main functions of futures contracts are price discovery and risk transfer. Futures prices are determined through open and competitive bidding among a large number of market participants. Because futures contracts are standardized and traded on a central exchange, prices can be readily observed and compared. The future price of a commodity may be the best indicator of its expected spot price in the future. Indeed, in a stable commodity market, the market price of a commodity must converge to the futures price by the time the futures contract expires, otherwise anyone could engage in arbitrage. Arbitrage occurs when the price of an asset traded on two or more markets is different. Profit is made by buying the asset at the low price in one market and selling it at a higher price in another market. Risk transfer is the other main function of the futures market. Participants in the futures market are generally classified as hedgers or speculators. Hedgers use futures contracts to offset and minimize the risks of price fluctuations. Speculators, on the other hand, are willing to accept this risk in the hope of earning a profit.

Source: Energy Information Administration, Office of Coal, Nuclear, Electric, and Alternate Fuels. 

Appendix A

History of the U.S.

Electric Power Industry, 1882-1991 



\section{Appendix A}

\section{History of the U.S. Electric Power Industry, 1882-1991 ${ }^{27}$}

\section{Beginnings: 1882-1900}

The modern electric utility industry began in the $1880 \mathrm{~s}$. It evolved from gas and electric carbon-arc commercial and street lighting systems. Thomas Edison's Pearl Street electricity generating station, which opened September 4, 1882 , in New York City, introduced the industry by featuring the four key elements of a modern electric utility system. It featured reliable central generation, efficient distribution, a successful end use (in 1882, the light bulb), and a competitive price. A model of efficiency for its time, Pearl Street used one-third the fuel of its predecessors, burning about 10 pounds of coal per kilowatthour, a "heat rate" equivalent of about 138,000 Btu per kilowatthour. ${ }^{228}$ Initially the Pearl Street utility served 59 customers for about 24 cents per kilowatthour. ${ }^{229} \mathrm{In}$ the late 1880 s, power demand for electric motors brought the industry from mainly nighttime lighting to 24-hour service and dramatically raised electricity demand for transportation and industry needs. By the end of the 1880 s, small central stations dotted many U.S. cities; each was limited to a few blocks' area because of transmission inefficiencies of direct current (dc).

The hydroelectric development of Niagara Falls by George Westinghouse in 1896 inaugurated the practice of placing generating stations far from consumption centers. The Niagara plant transmitted massive amounts of power to Buffalo, New York, over 20 miles away. With Niagara, Westinghouse convincingly demonstrated both the general superiority of transmitting power with electricity rather than by mechanical means (the use of ropes, hydraulic pipes, or compressed air had also been proposed) and the transmission superiority at that time of alternating current (ac) over dc. Niagara set a contemporary standard for generator size, and was the first large system supplying electricity from one circuit for multiple end-uses (railway, lighting, power).

Electric utilities spread rapidly in the 1890 s. Municipally owned utilities predominantly supplied street lighting and trolley services and reached their peak share of total generation, about 8 percent, at the turn of the century. ${ }^{230}$ Privately owned multiservice utilities controlled the rest of the industry, aggressively competing for central city markets. Competition and technological improvements served to lower electricity prices steadily, with nominal residential prices falling to less than 17 cents per kilowatthour by the beginning of the 20th century.

\section{Era of Private Utilities: 1901-1932}

From 1901 through 1932, growing economies of scale hastened growth and consolidation in the electric utility industry, as well as the beginnings of State and Federal regulation. Larger, more efficient steam turbine-powered generators quickly replaced reciprocating steam engines; average heat rates dropped from 92,500 Btu per kilowatthour in 1902 to 20,700 Btu per kilowatthour by $1932 . .^{231}$ As a direct consequence of those growing efficiencies, small private and municipal lighting and railway or power companies either merged with,

\footnotetext{
227 The following is a historical sketch of the electric power industry from 1882 through 1991 . The information for utilities from 1882 to 1984 is excerpted from the Annual Outlook for U.S. Electric Power 1985. Utility and nonutility information from 1985 to 1991 is excerpted from The Changing Structure of the U.S. Electric Power Industry 1970-1991.

${ }^{228}$ C. E. Neil, "Entering the Seventh Decade of Electric Power, Some Highlights in the History of Electrical Development," reprinted from Edison Electric Institute Bulletin (September 1942), p. 6.

${ }^{229}$ A.J. Foster, The Coming of the Electrical Age to the United States (New York, NY: Arno Press, 1979), pp. 120, $123,181$.

${ }^{230}$ Edison Electric Institute, Historical Statistics of the Electric Utility Industry Through 1970 (New York, NY), p. 24.

${ }^{231}$ C.E. Neil, "Entering the Seventh Decade of Electric Power," from Edison Electric Institure Bulletin (September 1942), p. 6.
} 
purchased electricity from, or were absorbed quickly by ever-larger, more efficient private multiservice systems. Systems and cities interconnected with high voltage transmission lines. Private electric utility ownership also consolidated into large utility holding companies, each "holding" controlling interest in a number of electric utilities. At their peak in the late 1920s, the 16 largest electric power holding companies controlled over 75 percent of all U.S. generation. ${ }^{232}$

The growth of utility service areas, first beyond city boundaries and then across State lines, brought State regulation of electric utilities in the early 1900 s. Georgia, New York, and Wisconsin established State public service commissions in 1907, followed quickly by more than 20 other States. Basic State powers included the authority to franchise the utilities, to regulate their rates, financing, and service, and to establish utility accounting systems.

The foundations for strong Federal involvement in the electricity industry were established between 1901 and 1932, based on three factors: first, the electric power industry became recognized as a natural monopoly in interstate commerce (producing a product most efficiently provided by one supplier) subject to Federal regulation; second, the Federal Government owned most of the Nation's hydroelectric resources; and third, Federal economic development programs accelerated, including electricity generation. In 1906, Congress authorized the sale of surplus Federal power from western irrigation projects, giving sale preference to municipalities. The Federal Water Power Act of 1920 (P.L. 66-280) codified Federal powers and established the Federal Power Commission (FPC) to issue hydroelectric development licenses revokable after 50 years. In 1928 Congress authorized the Boulder Canyon Project for irrigation, flood control, and electricity production.

From 1901 to 1932, electric utility capacity and generation grew at annual average rates of about 12 percent a year, despite a 14-percent absolute drop in generation from 1929 to the Depression-era low in 1932. Both the number of municipal utilities and their share of total generation dropped steadily, as municipals were overwhelmed by larger, more efficient private systems. By 1932 municipals contributed only 5 percent of total generation. At the same time, State-owned utilities and Federal systems, however, grew noticeably, together contributing over 1 percent of total generation. Private utilities provided the remaining
94 percent. $^{233}$ Electricity prices dropped, with nominal residential electricity prices falling to 5.6 cents per kilowatthour in 1932, a level about one-third their price at the beginning of the century. In 1907, only 8 percent of all dwellings were using electricity; by 1932, this figure had risen to 67 percent. By 1932 considerably more than 80 percent of urban dwellings were electrified, while only 11 percent of farm dwellings had electrical service. This disparity between urban and rural service led to demands by farm interests for government help in obtaining electric power. ${ }^{234}$

\section{Emergence of Federal Power: 1933-1950}

The Federal Government became a regulator of private utilities in the 1930s; it also became a major producer of electricity beginning in this period. The 1933-1950 period was also characterized by continued growth of the industry, increased consolidation and interconnection, and increasing economies of scale.

\section{3-1941}

The Federal Government moved quickly in the mid-1930s to regulate private power and, where opportunities appeared, to produce and distribute less expensive Federally produced electricity to preference customers. Federal participation was hastened by widespread public perception of private utility abuses and national efforts to overcome the Depression.

First, the Federal Government moved to regulate private utilities. To counter utility abuses beyond State control, the Public Utility Holding Company Act of 1935 (PUHCA, P.L. 74-333) provided for the regulation of utility holding companies by the Securities and Exchange Commission (SEC). The Federal Power Act of 1935 (Title II of PUHCA) established FPC regulation of utilities involved in interstate wholesale transmission and sale of electric power.

Second, the Federal Government encouraged the growth of rural electricity service by subsidizing the formation of rural electric cooperatives. The Rural Electrification Act of 1936 (P.L. 74-605) established the Rural Electrification Administration (REA) to provide loans and assistance to

\footnotetext{
${ }^{232}$ Encyclopedia Americana, International Edition, Vol. 22 (New York, NY: Americana Corporation, 1977), p. 769.

${ }^{233}$ Edison Electric Institute, Historical Statistics of the Electric Utility Industry Through 1970, p. 24.

${ }^{234}$ U.S. Bureau of the Census, Historical Statistics of the United States, Colonial Times to 1970, Bicentennial Edition, Part 2 (Washington, DC, 1975),
} p. 827. 
organizations providing electricity to rural areas and towns with populations under 2,500. REA-backed cooperatives enjoyed Federal power preferences plus lower property assessments, exemptions from Federal and State income taxes, and exemption from State and FPC regulation. As a result, by 1941 the proportion of farm homes electrified rose to 35 percent, more than three times that of $1932 .{ }^{235}$

Third, in the 1930s Federal electricity generation expanded, providing less expensive electricity to municipals and cooperatives. Large Bureau of Reclamation dams began serving the western States; Hoover Dam began generation in 1936, followed by other large projects. Grand Coulee, the Nation's largest hydroelectric dam, began operation in 1941. U.S. Army Corps of Engineers flood control dams provided additional low-priced power for preference customers. Under the Tennessee Valley Authority Act of 1933 (P.L. 73-17), the Federal Government supplied electric power to States, counties, municipalities, and nonprofit cooperatives, soon including those of the REA. The Bonneville Project Act of 1937 (P.L. 75-329) pioneered the Federal power marketing administrations. By 1940, Federal power pricing policy was set; all Federal power was marketed at the lowest possible price while still covering costs. From 1933 to 1941, half of all new capacity was provided by Federal and other public power installations. By the end of 1941, public power contributed 12 percent of total utility generation, with Federal power alone contributing almost 7 percent. ${ }^{236}$

During the pre-World War II years, electricity generating systems continued to grow in size and efficiency. Maximum turbine sizes and pressures doubled, and steam temperatures increased; generator cooling by pressurized hydrogen was introduced, resulting in higher generator outputs. Average heat rates dropped to 18,600 Btu per kilowatthour by $1941 .{ }^{237}$ Improvements in transformers, circuit breakers, protection and reclosing devices, and transmission and distribution systems also continued, increasing both the efficiency and the reliability of electric utility systems.

Electricity prices continued to decline. Nominal residential electricity prices fell to 3.73 cents per kilowatthour in 1941, a drop of about one-third from 1932. Demand for electric power grew steadily from 1932 to 1941, with generation growth averaging over 8 percent a year, although capacity increased less than 2.5 percent per year.

\section{2-1950}

Soaring electricity demand during World War II was met by increased use of privately owned capacity and a dramatic growth in Federal power. From 1941 to 1945, Federal capacity growth averaged 21 percent a year, and generation grew by 27 percent. By the war's end, Federal electricity generation had grown to over 12.5 percent of U.S. generation. ${ }^{238}$ Total U.S. generation grew at an annual average rate of over 7.5 percent during these war years, with capacity increasing at an annual average rate of almost 4.5 percent.

Both residential and commercial end use of electricity grew rapidly from 1941 to 1945 , despite the war. Almost one-half of all farm dwellings were electrified by 1945 . Growth in demand was helped by continuing technological improvements, yielding overall heat rates below 16,000 Btu per kilowatthour ${ }^{239}$ and residential electricity price drops averaging over 2 percent a year.

Public and Federal power continued to grow, and terms of public sale improved. Generating capacity built for defense was directed to public sale. The 1944 Pace Act (Department of Agriculture Organic Act, P.L. 78-425) extended REA indefinitely, dropped REA long-term interest rates below market rates, and authorized additional dam construction. The Flood Control Act of 1944 (P.L. 78-534) gave the Secretary of Interior jurisdiction over Corps of Engineers' electric power sales and extended public preference to all Corps power. The Southwestern Power Administration (SPA) and the Southeastern Power Administration (SEPA) were established in 1943 and 1950, respectively, to market Federal power to preference customers. The First Deficiency Appropriation Act of 1949 (P.L. 81-71) in effect authorized TVA construction of thermal-electric power plants for commercial electricity sale. By 1950, Federal generation contributed over 12 percent of total U.S. generation, while cooperatives and other public power provided almost 7 percent. ${ }^{240}$ In settling the Hope Natural Gas case (Federal Power Commission vs. Hope Natural

${ }^{235}$ U.S. Bureau of the Census, Historical Statistics of the United States, p. 827.

${ }^{236}$ Edison Electric Institute, Historical Statistics of the Electric Utility Industry Through 1970, pp. 2, 24.

${ }^{237}$ C.E. Neil, "Entering the Seventh Decade of Electric Power," from Edison Electric Institute Bulletin (September 1942), p. 6.

${ }^{238}$ Edison Electric Institute, Historical Statistics of the Electric Utility Industry Through 1970, p. 24.

${ }^{239}$ Edison Electric Institute, EEI Pocketbook of Electric Utility Industry Statistics (New York, NY: 1983), p. 21.

${ }^{240}$ Edison Electric Institute, Historical Statistics of the Electric Utility Industry Through 1970, p. 24. 
Gas Company, 1944), the Supreme Court closed a longstanding dispute by allowing either original or replacement cost accounting in utility ratemaking, so long as just and reasonable rates result.

Following a brief decline at war's end in 1945, overall demand for electricity continued to grow. From 1945 through 1950, generation growth averaged over 8 percent a year and capacity over 6.5 percent. Residential electricity consumption grew most rapidly, almost 14 percent a year, and the share of farms electrified rose to almost 80 percent. $^{241}$ Growth was encouraged by continued efficiency improvements; by 1950 heat rates had fallen below 15,000 Btù per kilowatthour. ${ }^{242}$ Drops in nominal residential electricity prices averaged 3 percent a year.

\section{Utility Prosperity: 1951-1970}

The era following the end of World War II through 1970 marks a time of essentially uninterrupted prosperity for the electric utility industry. Demand for electricity grew rapidly, consistently, and predictably, while electricity prices continued to fall. The arrival of commercial nuclear power held the promise of an even more prosperous future. At the same time, problems that were later to affect the industry dramatically either did not exist or were not yet serious.

\section{The 1950s}

Three major characteristics mark the electric utility industry in the 1950s: robust growth, the introduction of commercial nuclear power, and other public power expansion replacing Federal power growth.

From 1950 to 1960, generation grew by an average of over 8.5 percent a year, led by strong increases in residential electricity demand and near completion of rural electrification. Capacity grew slightly more rapidly than generation, averaging almost 9.5 percent annually. With generating efficiencies still improving, electricity prices continued to decline, as evidenced by drops in nominal residential electricity prices averaging about 1 percent a year. ${ }^{243}$
Commercial nuclear power was introduced in the 1950s. The Atomic Energy Act of 1954 (P.L. 83-703) allowed private development of commercial nuclear power, and the Price-Anderson Act (P.L. 85-256) reduced private liability by guaranteeing public compensation in the event of a commercial nuclear catastrophe. The Nation's first central station commercial nuclear reactor, located in Shippingport, Pennsylvania, began operation in 1957.

Finally, during the 1950s new Federal power plant construction slowed, but the slowdown was offset by more rapid growth of other public power capacity. Both the "no new starts" policy of the Eisenhower Administration and a lack of additional major hydroelectric sites checked major new Federal development. Nevertheless, projects begun earlier continued to come on line, and Federal generation reached its highest share of total generation, over 17 percent, in 1957. TVA added thermal capacity, by 1960 becoming predominantly a thermal rather than hydroelectric system. Non-Federal public power grew rapidly in the 1950 s, led by cooperatives, power districts, and State projects. Generation from non-Federal public power plants and cooperatives increased from over 6.5 percent of total generation in 1950 to almost 8.5 percent in $1960 .{ }^{244}$

\section{The 1960s}

During the 1960s high electricity growth rates continued, paralleled by growth in nuclear power generation. During the period, however, signs of future difficulties in the electric power industry appeared, including decreasing efficiency gains, escalating costs, and environmental concerns.

Vigorous growth continued throughout the 1960s, prompted by overall economic growth, declining real energy prices, and growing consumer preference for electricity because of its convenience, versatility, and price. Generation and capacity growth averaged almost 7.5 percent a year, predominantly from increases in petroleum and gas-fired generation. Cooperatives accelerated capacity additions, and by 1970 non-Federal public power contributed well over 10 percent of total utility generation. ${ }^{245}$ Demand grew nearly 7.5 percent a

\footnotetext{
${ }^{241}$ U.S. Bureau of the Census, Historical Statistics of the United States, pp. 827-828.

${ }^{242}$ Derived from Edison Electric Institute, EEI Pocketbook of Electric Utility Industry Statistics (1983), p. 21.

${ }^{243}$ Residential price declines for 1950 to 1960 are derived solely from Edison Electric Institute data.

${ }^{244}$ Edison Electric Institute, Historical Statistics of the Electric Utility Industry Through 1970, p. 24.

${ }^{245}$ Edison Electric Institute, Historical Statistics of the Electric Utility Industry Through 1970, p. 24.
} 
year, helped by annual declines of over 1.5 percent in residential and commercial electricity prices. ${ }^{246}$

New technology introduced during this period included automated controls and computers. Technological advances during the 1960s were led by the growth of commercial nuclear power. Facing continued high demand growth and encouraged by performance of small nuclear facilities, utilities began ordering many more nuclear units of far greater size and still undemonstrated efficiency. In contrast to the 837 megawatts of new capacity ordered in the 1950 s, with units averaging fewer than 150 megawatts, in the $1960 \mathrm{~s}, 86,596$ megawatts were ordered, averaging about 850 megawatts per unit. ${ }^{247}$ Generation by nuclear power rose to over 1 percent of the U.S total by $1970 .{ }^{248}$

During the 1960s some signs of difficulties in the electric utility industry began to appear. First, environmental requirements became a noticeable component of electric utility costs. Coal-fired power plants began to experiment with emission control equipment to decrease the amount of sulfur dioxide $\left(\mathrm{SO}_{2}\right)$ emitted into the atmosphere. Tall emission stacks were introduced to disperse $\mathrm{SO}_{2}$. Further, the National Environmental Policy Act of 1969 (NEPA, P.L. 91-190) required utilities seeking Federal permits for new power plants to prepare and defend environmental impact statements (EIS) as a part of the permit process. Second, the increasing efficiencies historically characterizing the industry flattened in the mid-1960s. From 1960 to 1970 , the average size of thermal plants more than doubled. Heat rates, on the other hand, declined only a little, from about 10,800 Btu per kilowatthour to 10,500 Btu per kilowatthour. ${ }^{249}$ Finally a major Northeastern power blackout in 1965 raised concerns about the reliability of the huge interconnected, interdependent power networks; response to the blackout included formation of regional reliability councils, and the North American Electric Reliability Council (NERC) to promote the reliability and adequacy of bulk power supply.

\section{Years of Challenge: 1971-1984}

\section{The 1970s}

During the 1970s, the electric utility industry moved from decreasing unit costs and rapid growth to increasing unit costs and slower growth. Among the major factors affecting the electric utility industry during the period were general inflation, increases in fossil-fuel prices, environmental concerns, conservation, and problems in the nuclear power industry.

First, electric utilities with ambitious capital expansion programs heavily financed by borrowing were particularly affected by inflation. As technical and regulatory requirements increased construction lead times, the impact of inflation was compounded.

Second, in the 1970s all fossil-fuel prices rose sharply. Petroleum costs more than doubled in 1974 alone and increased an average of over 26 percent a year for the 1970-1980 period. Natural gas prices, accelerated by decontrol under the Natural Gas Policy Act (NGPA, P.L. 95-621), rose by over 23 percent a year, with the largest increases occurring after 1978. Coal price increases averaged almost 16 percent a year. ${ }^{250}$

Third, during the 1970 s environmental legislation increased the costs of building and operating electric utility (particularly coal-fired) power plants. The Clean Air Act of 1970 (CAA, P.L. 91-604) and its amendments in 1977 (P.L. 95-95) required utilities to reduce pollutant emissions, particularly $\mathrm{SO}_{2}$, causing increases in capital, fuel, and operating costs. The Act also limited use of tall stacks to disperse emissions. The Federal Water Pollution Control Act of 1972 ("Clean Water Act," P.L. 92-500) limited utility waste discharges into water. In addition, the Resource Conservation and Recovery Act of 1976 (RCRA, P.L. 94-580) directed standards for disposal of both hazardous and nonhazardous utility wastes.

\footnotetext{
${ }^{246}$ Energy Information Administration, Annual Energy Review 1984, DOE/EIA-0384(84) (Washington, DC, April 1985 ), p. 187.

${ }^{247}$ Energy Information Administration, U.S Commercial Nuclear Power Historical Perspective, Current Status, and Outlook, DOE/EIA-0315 (Washington, DC, March 1982), p. 10.

${ }^{248}$ Energy Information Administration, Annual Energy Review 1984, p. 171.

249 Energy Information Administration, Thermal-Electric Plant Construction Cost and Annual Production Expenses-1979, DOE/EIA-0323(79) (Washington, DC, May 1982), p. 10.

${ }^{250}$ Energy Information Administration, "Fuel Choice in Steam Electric Generation: A Retrospective Analysis," Volume 1, Overview, Draft Report, Table 2.
} 
Finally, conservation legislation effectively barred utilities from wider use of natural gas and petroleum. The Energy Supply and Environmental Coordination Act of 1974 (ESECA, P.L. 93-319) allowed the Federal Government to prohibit electric utilities from burning natural gas or petroleum. The 1978 Powerplant and Industrial Fuel Use Act (FUA, P.L. 95-620) succeeded ESECA and extended Federal prohibition powers. The National Energy Conservation Policy Act of 1978 (NECPA, P.L. 95-619) required utilities to provide residential consumers free conservation services to encourage slower growth of electricity demand.

Expected high electricity demand growth did not materialize in the 1970s. Instead, capacity growth began to outrun increases in demand. For the first time in the history of U.S. electric power, electricity prices rose consistently, with nominal price increases averaging 11 percent a year. Consequently, demand and generation growth moderated to just over 4 percent a year. However, capacity growth continued at a rate of 6 percent a year. Slackened demand growth, coupled with completion of expensive new capacity, left utilities with excess capacity and without new revenues to pay for it. As a result, some electric utilities suffered financial setbacks and incurred declining investor confidence.

The commercial nuclear power industry expanded rapidly but also met serious reverses. From 1971 through 1974, 131 new nuclear units were ordered, at an average capacity of about 1,100 megawatts. ${ }^{251}$ Inflation and real labor and materials cost increases quickly affected construction costs of nuclear power plants, while high interest rates raised financing costs. Capital costs rose from about $\$ 150$ per kilowatt in 1971 to over $\$ 600$ after $1976 .{ }^{252}$ Utilities building commercial nuclear facilities faced financial difficulties in justifying and meeting these increased costs. Safety concerns increased. First, in February 1979 the Nuclear Regulatory Commission (NRC) shut down five operating reactors following concerns about durability during earthquakes. Then, on March 28, 1979, the Nation's most significant commercial nuclear accident occurred at the Three Mile Island Number 2 reactor near Harrisburg, Pennsylvania.

These events heightened public concerns and spurred opposition to commercial nuclear power.
As a result of higher costs, slackening electricity demand growth, and public concern, demand for nuclear power plants dropped quickly in the mid- and late-1970s. After 1974, new orders plummeted and cancellations accelerated. No new reactor orders were placed after 1978. Moreover, 63 units were canceled between 1975 and $1980 . .^{253}$

\section{The Early 1980s}

The early 1980s were marked by almost no growth in the U.S. electric utility industry. In 1982 total net generation dropped more than 2 percent, the first absolute decline since 1945. In the mid-1980s, however, the industry returned to moderate if unspectacular growth.

Cost and price increases continued to slow the growth of electric power in the early 1980 s. Costs of new nuclear power plants increased to over $\$ 1,200$ per kilowatt of capacity in the early 1980s. ${ }^{254}$ High inflation ensured increases in other financial and operating costs. As a result, electricity prices rose sharply. Average end-use electricity prices (nominal) increased by almost 19 percent in 1980, 15 percent in 1981, and 12 percent in 1982. End-use electricity consumption responded to rising prices and a sluggish economy by increasing only 1 percent in 1980 and 2.5 percent in 1981. Demand then dropped almost 3 percent in 1982, because of a decline in industrial electricity use of nearly 10 percent, as part of that year's severe economic downturn. ${ }^{255}$

However, other factors also slowed cost increases in the early 1980s. Growth in Federal fuel use restrictions slowed. The Omnibus Budget Reconciliation Act of 1981 (P.L. 97-35) reduced Federal authority to issue oil and natural gas use prohibitions. Additional Clean Air Act amendments were considered but not enacted. Despite the accelerated decontrol of petroleum prices, worldwide oil surpluses in the early 1980 s resulted in lower utility oil costs and provided some relief. Finally, while the recession of 1982 undoubtedly hurt electricity sales, it lowered the rate of overall inflation, resulting in lower interest rates and lowered rates of increase in other capital, operating, and maintenance costs.

Electricity generation increased in 1983 to a record high of 2,310 billion kilowatthours. Capacity, however, grew by

${ }^{251}$ Energy Information Administration, U.S Commercial Nuclear Power (March 1982), p. 10.

252 Energy Information Administration, 1983 Survey of Nuclear Power Plant Construction Costs, DOE/EIA-0439(83) (Washington, DC, December 1983), p. 8.

${ }^{253}$ Energy Information Administration, U.S. Commercial Nuclear Power (March 1982), p. 10.

${ }^{254}$ Energy Information Administration, Survey of Nuclear Power Plant Construction Costs 1984, DOE/EIA-0439(84) (Washington, DC, November 1984), p. 15.

${ }^{255}$ Energy Information Administration, Annual Energy Review 1984, pp. 179, 187. 
little more than 1 percent over 1982, the smallest increase since 1956. Industrial electricity use grew most rapidly among end-use sectors, rebounding from its 1982 decline. The average price of electricity increased by 2.6 percent, less than the rate of inflation.

In 1984, electricity posted its largest single-year increase in generation since 1976, 4.5 percent. Though not large by historic standards, the growth rate reflected a healthy economy, generally increasing preference for electricity, and a decline in electricity's price relative to other forms of energy. Capacity grew by 2.1 percent in 1984, led by coal-fired and nuclear-powered additions. Electricity prices increased at the rate of inflation, leaving real prices unchanged.

From 1980 through 1984, net electricity generation grew an average of a mere 1.4 percent annually. Gross National Product grew at twice that, yielding a GNP ratio of only 0.5 . End-use sales grew by only 2.1 percent a year, the slowest rate of growth since the early years of the Great Depression. Capacity, however, increased 2.3 percent a year, further raising reserves available to meet unexpected demand. Nuclear capacity additions entering commercial service, despite the absence of new orders, led the rate of new capacity growth, increasing by 6.1 percent a year. Prices rose by approximately 8 percent a year. Commercial electricity use increased more than any other end use, averaging almost 4.5 percent a year; industrial end use grew less than 1 percent a year. ${ }^{256}$

\section{Nonutility Growth: The Late 1980 s $^{257}$}

In 1970, electric utilities supplied 93 percent of the electricity generated in the United States. The balance was produced by "nonutilities"-generators of electric power that are not utilities-consisting primarily of industrial manufacturers that produced electricity for their own use. The electric utility share of electric power generation increased steadily between then and 1979, when it reached 97 percent. The trend reversed itself in the 1980s, and by 1991 the electric utility share declined to 91 percent.

Increasingly, nonutilities were generating electricity not only for their own use but also for sale to electric utilities for distribution to final consumers. In 1991, nonutilities owned about 6 percent of the electric power generating capacity and produced about 9 percent of the total electricity generated in the United States. ${ }^{258}$

About one-half of 1991 nonutility capacity was located in the West South Central Census Division, particularly in Texas, and the Pacific Contiguous Census Division, particularly in California. Most nonutilities in Texas, which produced 49 billion kilowatthours of electricity in 1991, were engaged in chemical manufacturing, which provides many opportunities for generating electricity along with another form of energy (such as heat or steam). In California, which produced 53 billion kilowatthours in 1991, most nonutilities were engaged primarily in electricity generation.

In 1991, nonutilities produced 49 percent of their electricity from natural-gas-fired boilers, much more than from any other single primary energy source. In contrast, utilities produced the majority of their electricity by burning coal, and their second major source of energy was nuclear power. Renewable energy sources, except for hydroelectric power, were virtually untapped by electric utilities, while renewable fuels (including wood and waste) collectively produced the second largest share (34 percent) of nonutility electricity. One reason for the difference was that the majority of nonutility capacity was in the manufacturing sector of the economy, particularly in the chemical and paper industries. Both industries produce wastes as byproducts of the manufacturing process that can be used as a source of energy to drive electricity generators. Also, paper manufacturing uses a renewable fuel (wood) as a raw material in producing paper, making wood and wood waste easily accessible to paper manufacturers as an energy source for electricity generation.

As of December 1991, the process of change in the structure of the electric power industry had not yet run its course. Major issues are arising and include the effect of the changing industry structure on the reliability of electric power supply and on bulk (wholesale) power trade. Also at issue is whether the Clean Air Act Amendments of 1990 will alter the course of nonutility growth.

The concern with the Clean Air Act Amendments of 1990 centers on whether nonutilities will be able to obtain a sufficient number of emission allowances to operate in compliance with the Amendments. Beginning in 2000 (with an incremental phase for utilities beginning in 1995),

\footnotetext{
${ }^{256}$ Energy Information Administration, Annual Energy Review 1984, pp. 171, 179, 181, 187, and the U.S. Department of Commerce, Bureau of Economic Analysis.

${ }^{257}$ Reprinted from The Changing Structure of the U.S. Electric Power Industry, 1970-1991, DOE/EIA-0562 (Washington, DC, March 1993), pp. vii-ix.

${ }^{258}$ Edison Electric Institute, 1991 Capacity and Generation of Non-Utility Sources of Energy (Washington, DC, November 1992), p. 21.
} 
the Amendments require virtually all suppliers of wholesale electric power to obtain emission allowances for any sulfur dioxide released into the atmosphere. Utilities have been allocated most of these allowances. Nonutilities must obtain the allowances they need from utilities or from a sale or auction administered by the Federal Government. Allowances should be available to nonutilities, but there have not yet been enough trades to resolve their price. 
Appendix B

Historical Chronology of Energy-Related Milestones, 1800-1994 


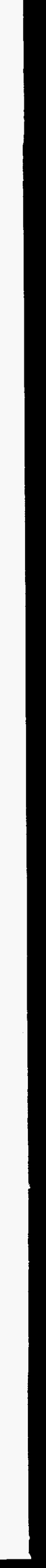




\section{Appendix B \\ Historical Chronology of Energy-Related Milestones, 1800-1994}

The following Historical Chronology of Energy Related Milestones provides an interesting look at technological and institutional events that have occurred throughout the history of the electric power industry.

Table B1. Historical Chronology of Energy-Related Milestones, 1800-1994

\begin{tabular}{|c|c|c|}
\hline Year & Technological & Institutional USA and Canada \\
\hline 1800 & First electric battery-A. Volta (Italy). & \\
\hline 1801 & Principles of arc light-H. Davy (UK). & \\
\hline 1808 & First effective arc lamp-H. Davy (UK). & \\
\hline 1816 & & $\begin{array}{l}\text { Gas Light Co. of Baltimore founded by R. Peale-first energy } \\
\text { utility in USA, predecessor of Baltimore G\&E. }\end{array}$ \\
\hline 1820 & $\begin{array}{l}\text { Relationship of electricity and magnetism } \\
\text { confirmed-H.C Oersted (Den.). }\end{array}$ & $\begin{array}{l}\text { Congress gives City of Washington authority to regulate some } \\
\text { prices. }\end{array}$ \\
\hline 1821 & First electric motor-M. Faraday (UK). & \\
\hline 1826 & Ohms Law-G.S. Ohm (Ger.). & \\
\hline 1831 & $\begin{array}{l}\text { Principles of electromagnetism, induction, } \\
\text { generation and transmission-M. Faraday (UK). }\end{array}$ & \\
\hline 1832 & $\begin{array}{l}\text { First dynamo-H. Pixii (France). } \\
\text { Faraday publishes on induction (UK). } \\
\text { J. Henry publishes on induction (USA). }\end{array}$ & \\
\hline 1837 & First industrial electric motors-T. Davenport (USA). & \\
\hline 1839 & First fuel cell-W. Grove (UK). & Rhode Island sets up regulatory commission. \\
\hline 1860 & Lead storage battery-G. Plante (France). & \\
\hline 1865 & $\begin{array}{l}\text { Mathematical theory of electromagnetic fields-J.C. } \\
\text { Maxwell (UK). }\end{array}$ & \\
\hline 1870 & First effective dynamo-Z.T. Gramme (Bel.). & \\
\hline 1872 & Gas turbine patent-F. Stulze (Ger.). & \\
\hline 1873 & & Outdoor arc lighting, Winnipeg. \\
\hline 1876 & $\begin{array}{l}\text { Improved arc light, Jablochoff candle-P. Jablochoff } \\
\text { (France). }\end{array}$ & Arc lights at Philadelphia exposition. \\
\hline 1877 & & Munn v. Illinois-U.S. Supreme Court upholds regulation. \\
\hline
\end{tabular}


Table B1. Historical Chronology of Energy-Related Milestones, 1800-1994 (Continued)

\begin{tabular}{|c|c|c|}
\hline Year & Technological & Institutional USA and Canada \\
\hline 1878 & $\begin{array}{l}\text { Efficient arc lamp and open coil dynamo-C.F. } \\
\text { Brush (USA). }\end{array}$ & $\begin{array}{l}\text { Edison Electric Light Co. (USA) and American Electric and } \\
\text { Illuminating of Montreal founded. }\end{array}$ \\
\hline 1879 & $\begin{array}{l}\text { T.A. Edison (USA) and J. Swan (UK) independently } \\
\text { invent practical incandescent lamp. }\end{array}$ & $\begin{array}{l}\text { First commercial power station opens in San Francisco, uses } \\
\text { Brush generator and arc lights. } \\
\text { British Columbia Electric Railway. }\end{array}$ \\
\hline 1880 & & First isolated power system, from Edison, for S.S. Columbia. \\
\hline 1881 & Electric streetcar-E.W. v. Siemens (Ger.). & \\
\hline 1882 & & $\begin{array}{l}\text { Edison's Pearl Street Station. } \\
\text { First hydroelectric station opens-Appleton, Wisconsin. }\end{array}$ \\
\hline 1883 & $\begin{array}{l}\text { Transformer invented—L. Gaulard (Fr.) and J. Gibbs } \\
\text { (UK). }\end{array}$ & $\begin{array}{l}\text { First electric lighting plant in Canada, Cornwall, Ont. } \\
\text { First electric tramway in USA, Richmond,VA-Sprague } \\
\text { design. }\end{array}$ \\
\hline 1884 & Steam turbine invented-C. Parsons (UK). & $\begin{array}{l}\text { Edison takes control of Edison Light Co. } \\
\text { Streetlights, Montreal and Tcronto. }\end{array}$ \\
\hline 1886 & $\begin{array}{l}\text { W. Stanley develops transformer and AC electric } \\
\text { system (USA). }\end{array}$ & Westinghouse Electric formed. \\
\hline 1888 & $\begin{array}{l}\text { N. Tesla invents induction motor and polyphase AC } \\
\text { system (USA). } \\
\text { O. Shellenberger invents induction motor, first AC } \\
\text { meter to measure consumption (USA). }\end{array}$ & \\
\hline 1889 & Impulse turbine patent-L. Pelton (USA). & $\begin{array}{l}\text { Edison General Electric formed. } \\
\text { National Association of Regulatory Commissioners founded } \\
\text { as association of railway commissioners. }\end{array}$ \\
\hline 1890 & & $\begin{array}{l}\text { First execution in electric chair. } \\
\text { The North American Co. formed. } \\
\text { United Electric Securities organized by Thomson-Houston. }\end{array}$ \\
\hline 1891 & $\begin{array}{l}\text { Westinghouse transmits hydro } \mathrm{AC} \text { at } 3.3 \mathrm{Kv} \text { for } 13 \\
\text { miles, Oregon. } \\
\text { C. Brown transmits at } 3.0 \mathrm{Kv} \text { for } 110 \text { miles (Ger). }\end{array}$ & \\
\hline 1892 & $\begin{array}{l}\text { T. Wilson develops electric furness process to } \\
\text { produce calcium carbide (Canada). }\end{array}$ & $\begin{array}{l}\text { General Electric (GE) formed by merger of Thomson-Houston } \\
\text { and Edison General Electric. } \\
\text { C. Steinmetz, theoretician of AC and mathematician joins GE, } \\
\text { beginning corporate industrial research in USA. }\end{array}$ \\
\hline
\end{tabular}


Table B1. Historical Chronology of Energy-Related Milestones, 1800-1994 (Continued)

\begin{tabular}{|c|c|c|}
\hline Year & Technological & Institutional USA and Canada \\
\hline 1893 & $\begin{array}{l}\text { Westinghouse displays AC system at Chicago } \\
\text { World's Fair. } \\
\text { Folsom Powerhouse in California transmits at } 11.0 \\
\text { Kv } 3 \text { phase AC, } 22 \text { miles to Sacramento. }\end{array}$ & AC chosen for Niagara Power. \\
\hline 1896 & Niagara line, $11.0 \mathrm{Kv}, 3$ phase $A C, 20$ miles & Niagara transmission line (Niagara Falls to Buffalo) opened. \\
\hline 1897 & J. Thompson discovers electron (UK). & $\begin{array}{l}\text { C. Yerkes proposes state regulation for streetcars and long } \\
\text { franchises. }\end{array}$ \\
\hline 1898 & & $\begin{array}{l}\text { Smith v. Ames. Supreme Court decrees just compensation } \\
\text { on fair value. } \\
\text { S. Insull proposes state regulation of utilities. }\end{array}$ \\
\hline 1900 & Highest voltage transmission line $60 \mathrm{Kv}$. & \\
\hline 1901 & $\begin{array}{l}\text { Westinghouse offers 3.5 Mw turbine. } \\
2.0 \mathrm{Mw} \text { turbine, largest installed in USA. }\end{array}$ & $\begin{array}{l}\text { First power transmission line between USA and } \\
\text { Canada-Niagara Falls. }\end{array}$ \\
\hline 1902 & 5.0 Mw turbine for Fisk St. Station, Chicago. & \\
\hline 1903 & First successful gas turbine (France). & $\begin{array}{l}\text { World's first all turbine station, Chicago. } \\
\text { Shawinigan Water \& Power installs world's largest generator } \\
\text { (5000W) and world's largest and highest voltage line-136 } \\
\mathrm{Km} \text { and } 50 \mathrm{Kv} \text { (to Montreal). }\end{array}$ \\
\hline 1906 & & Associated G\&E incorporated. \\
\hline 1907 & $\begin{array}{l}\text { Electric vacuum cleaner-J. Spangler (USA). } \\
\text { Electric washing machine-A. Fisher (USA). }\end{array}$ & State utility regulation in Mass., N.Y., and Wis. \\
\hline 1909 & $\begin{array}{l}\text { First pumped storage plant, } 1,500 \mathrm{Kw} \text {, } \\
\text { Schlaffhausen (Switzerland). }\end{array}$ & . \\
\hline 1910 & $\begin{array}{l}\text { Neon lamps. } \\
\text { Tungsten wire filament. }\end{array}$ & S. Insull electrifies rural communities. \\
\hline 1911 & Air conditioning-W. Carrier (USA). & \\
\hline 1912 & $\begin{array}{l}\text { Largest generator } 35 \mathrm{MW} \text {, highest transmission } \\
\text { voltage, } 150 \mathrm{Kv} \text {. }\end{array}$ & Insull starts holding company. \\
\hline
\end{tabular}


Table B1. Historical Chronology of Energy-Related Milestones, 1800-1994 (Continued)

\begin{tabular}{|c|c|c|}
\hline Year & Technological & Institutional USA and Canada \\
\hline 1913 & $\begin{array}{l}\text { Gas filled incandescent lamps. } \\
\text { First air pollution control device-cinder catcher-T. } \\
\text { Murray (USA). } \\
\text { Electric refrigerator-A. Goss (USA). }\end{array}$ & \\
\hline 1914 & & Illinois forms regulatory agency. \\
\hline 1916 & & $\begin{array}{l}\text { Federal government begins construction of Muscle Shoals, } \\
\text { Ala., dam to supply electricity to munitions complex. Origin of } \\
\text { TVA. }\end{array}$ \\
\hline 1919 & Atomic fission-E. Rutherford (Can.). & \\
\hline 1920 & First U.S. station to only burn pulverized coal. & Federal Power Commission (FPC). \\
\hline 1922 & $175 \mathrm{Mw}$ largest generating station. & $\begin{array}{l}\text { Associated Gas and Electric Incorporated. } \\
\text { Connecticut Valley Power Exchange (CONVEX) starts, } \\
\text { pioneering interconnection between utilities. }\end{array}$ \\
\hline 1923 & Television components-V. Zworkyin (USA). & Bluefield decision calls for reproduction cost rate base. \\
\hline 1924 & & Cities Service Power \& Light. \\
\hline 1926 & & A.B. Collins creates Reddy Kilowatt. \\
\hline 1927 & & $\begin{array}{l}\text { First regional power pool, Pennsylvania-New Jersey } \\
\text { Interconnection. } \\
\text { Rhode Island PUC v. Attleboro-selling electricity interstate } \\
\text { cannot be regulated by state. }\end{array}$ \\
\hline 1928 & $\begin{array}{l}\text { Construction of Boulder Dam begins. } \\
\text { F. Whittle publishes thesis proposing gas turbines } \\
\text { for aircraft propulsion (UK). }\end{array}$ & $\begin{array}{l}\text { Federal Trade Commission begins investigation of holding } \\
\text { companies. }\end{array}$ \\
\hline 1929 & $\begin{array}{l}\text { GE produces } 208 \mathrm{Mw} \text { generating unit, largest in } \\
\text { service through } 1953 \text {. }\end{array}$ & $\begin{array}{l}\text { Commonwealth \& Southern and United Corp. organized. } \\
\text { Stock market crashes. }\end{array}$ \\
\hline 1930 & $\begin{array}{l}\text { Transmission at } 240 \mathrm{Kv} \text {. } \\
\text { Jet engine patented-F. Whittle (UK). }\end{array}$ & \\
\hline 1932 & Sodium light. & $\begin{array}{l}\text { Middle West Utilities, National Electric Power, Seaboard P.S. } \\
\text { collapse-end of Insull empire. }\end{array}$ \\
\hline 1933 & & Tennessee Valley Authority (TVA) established. \\
\hline
\end{tabular}


Table B1. Historical Chronology of Energy-Related Milestones, 1800-1994 (Continued)

\begin{tabular}{|c|c|c|}
\hline Year & Technological & Institutional USA and Canada \\
\hline 1934 & Nuclear chain reaction described-L. Szilard (UK). & \\
\hline 1935 & & $\begin{array}{l}\text { Public Utility Holding Co. Act. } \\
\text { Federal Power Act. } \\
\text { Securities and Exchange Commission. } \\
\text { Bonneville Power Administration. } \\
\text { First night baseball game in major leagues (Cincinnati, Ohio). }\end{array}$ \\
\hline 1936 & $\begin{array}{l}\text { Highest steam temperature reaches } 900 \text { degrees } \\
\text { Fahrenheit vs. } 600 \text { degrees Fahrenheit in early } \\
1920 \text { s. } \\
287 \mathrm{Kv} \text { line runs } 266 \text { miles to Boulder (Hoover) } \\
\text { Dam. } \\
\text { Boulder Dam completed. }\end{array}$ & Rural Electrification Act. \\
\hline 1938 & $\begin{array}{l}\text { Man-made fission of uranium }-\mathrm{O} \text {. Hahn and } \mathrm{F} \text {. } \\
\text { Strassman (Ger.). }\end{array}$ & $\begin{array}{l}\text { Supreme Court affirms Holding Co. Act of } 1935 \text { in Electric } \\
\text { Bond \& Share v. SEC. }\end{array}$ \\
\hline 1939 & $\begin{array}{l}\text { First jet flight-engine developed by H.P. von Ohain } \\
\text { working with E. Heinkel (Ger.). }\end{array}$ & \\
\hline 1940 & $\begin{array}{l}\text { Steam pressure in generation reaches } 2400 \text { pounds } \\
\text { per square inch (psi) vs. } 1100 \text { psi in early } 1920 \text { s. }\end{array}$ & Nonutility generation accounts for $21 \%$ of USA total. \\
\hline 1941 & First flight with Whittle jet engine (UK). & \\
\hline 1942 & Sustained nuclear reaction-E. Fermi (USA). & \\
\hline 1943 & & $\begin{array}{l}\text { SEC orders divestments of Engineers P.S. subsidiaries, } \\
\text { begins breakup of holding companies. }\end{array}$ \\
\hline 1944 & & $\begin{array}{l}\text { Hydro-Quebec formed. } \\
\text { F.P.C. v. Hope Natural Gas decision establishes new rules for } \\
\text { regulation. }\end{array}$ \\
\hline 1945 & Atomic Bomb. & \\
\hline 1946 & & $\begin{array}{l}\text { Atomic Energy Act, establishes Atomic Energy Commission } \\
\text { (AEC). }\end{array}$ \\
\hline 1947 & $\begin{array}{l}\text { Transistor invented. } \\
\text { Mercury vapor lamp. } \\
\text { Highest steam temperature in generation reaches } \\
1000 \text { degrees Fahrenheit. }\end{array}$ & \\
\hline 1950 & & Nonutility generation accounts for $15 \%$ of USA total. \\
\hline
\end{tabular}


Table B1. Historical Chronology of Energy-Related Milestones, 1800-1994 (Continued)

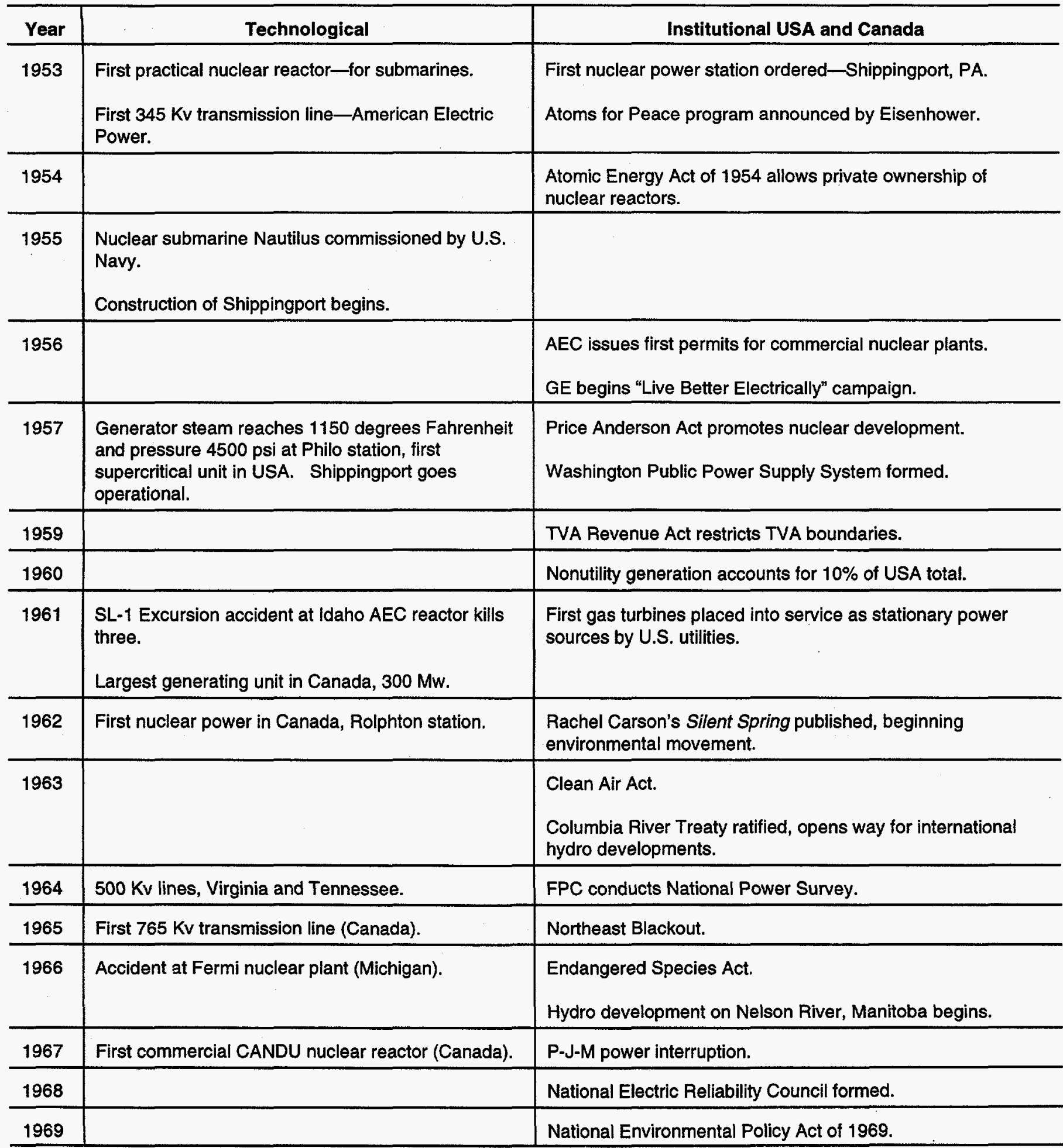


Table B1. Historical Chronology of Energy-Related Milestones, 1800-1994 (Continued)

\begin{tabular}{|c|c|c|}
\hline Year & Technological & Institutional USA and Canada \\
\hline 1970 & & $\begin{array}{l}\text { National Power Survey by FPC. } \\
\text { Environmental Protection Agency (EPA) formed. } \\
\text { Water and Environmental Quality Act. } \\
\text { Clean Air Act of } 1970 . \\
\text { Earth Day-April } 22 .\end{array}$ \\
\hline 1972 & & $\begin{array}{l}\text { Electric Power Research Institute (EPRI). } \\
\text { Clean Water Act of } 1972 . \\
\text { Power production begins at Churchill Falls (Canada). }\end{array}$ \\
\hline 1973 & & $\begin{array}{l}\text { Arab oil embargo begins, price of oil quadruples. } \\
\text { Endangered Species Act of } 1973 \text {. } \\
\text { Natural gas production peaks. }\end{array}$ \\
\hline 1974 & $\begin{array}{l}\text { Number of nuclear plants on order or under } \\
\text { construction reached peak. }\end{array}$ & $\begin{array}{l}\text { First drop in sales since } 1946 . \\
\text { AEC split up into Energy Research and Development } \\
\text { Administration (ERDA) and Nuclear Regulatory Commission } \\
\text { (NRC). } \\
\text { Consolidated Edison omits dividend. } \\
\text { Churchill Falls hydro plant completed (Canada). }\end{array}$ \\
\hline 1975 & Brown's Ferry nuclear accident. & Thirteen nuclear projects canceled. \\
\hline 1977 & & $\begin{array}{l}\text { New York City blackout. } \\
\text { Department of Energy (DOE) formed. } \\
\text { Carter energy plan. }\end{array}$ \\
\hline 1978 & & $\begin{array}{l}\text { Public Utilities Regulatory Policies Act (PURPA) passed, ends } \\
\text { utility monopoly over generation. } \\
\text { Natural Gas Policy Act partially deregulates wellhead prices. } \\
\text { Power Plant and Industrial Fuel Use Act limits use of natural } \\
\text { gas in electric generation (repealed 1987). } \\
\text { U.S. Supreme Court affirms primacy of FERC ratesetting in } \\
\text { Narragansett decision. }\end{array}$ \\
\hline 1979 & $\begin{array}{l}\text { Three Mile Island nuclear accident. } \\
\text { N. Wertheimer and E. Leeper publish studies linking } \\
\text { EMF to cancer (USA). }\end{array}$ & $\begin{array}{l}\text { Hydro-Quebec's James Bay project begins operation } \\
\text { (Canada). } \\
\text { Oil prices jump } \$ 11 \text { due to Iranian Revolution. }\end{array}$ \\
\hline
\end{tabular}


Table B1. Historical Chronology of Energy-Related Milestones, 1800-1994 (Continued)

\begin{tabular}{|c|c|c|}
\hline Year & Technological & Institutional USA and Canada \\
\hline 1980 & First U.S. windfarm (N.H.). & $\begin{array}{l}\text { Pacific Northwest Electric Power Planning and Conservation } \\
\text { Act establishes regional regulation and planning. }\end{array}$ \\
\hline 1981 & & $\begin{array}{l}\text { PURPA ruled unconstitutional by Federal judge-Mississippi } \\
\text { (decisions overturned 1982). }\end{array}$ \\
\hline 1982 & $\begin{array}{l}\text { Shippingport retired from service. } \\
\text { Record drop of } 19 \text { plants from list of nuclear plants } \\
\text { in operation, under construction, or ordered. }\end{array}$ & $\begin{array}{l}\text { Nuclear Waste Policy Act directs DOE to build geological } \\
\text { repository for waste. } \\
\text { U.S. Supreme Court upholds legality of PURPA in FERC v. } \\
\text { Mississippi ( } 456 \text { US 742). }\end{array}$ \\
\hline 1983 & $\begin{array}{l}\text { First denial of operating license by NRC (Byron, \#1, } \\
\text { Illinois). }\end{array}$ & $\begin{array}{l}\text { Washington Public Power Supply System defaults on } \$ 2.25 \\
\text { billion of bonds due to inability to complete five nuclear } \\
\text { reactors. } \\
\text { P.S. of Indiana cancels Marble Hill nuclear plant, cuts } \\
\text { dividend. } \\
\text { Cincinnati G\&E suspends Zimmer as nuclear project, } \\
\text { announces conversion of Zimmer to coal. } \\
\text { Production of electricity from nonutility sources hits lowest } \\
\text { level since } 1950 \text {. }\end{array}$ \\
\hline 1984 & $\begin{array}{l}\text { Annapolis, N.S., tidal power plant-first of its kind in } \\
\text { North America (Canada). }\end{array}$ & \\
\hline 1986 & Chernobyl nuclear accident (USSR). & \\
\hline 1987 & & $\begin{array}{l}\text { Nonutility generation exceeds } 5 \% \text { of USA total for first time } \\
\text { since } 1974 \text {. }\end{array}$ \\
\hline 1988 & $\begin{array}{l}\text { NASA scientist J. Hansen tells Congress that } \\
\text { greenhouse effect already taking place. }\end{array}$ & $\begin{array}{l}\text { Public Service of New Hampshire files for bankruptcy due to } \\
\text { nuclear project-first utility bankruptcy in more than } 50 \text { years. } \\
\text { FERC approves merger of Pacific P\&L and Utah P\&L with } \\
\text { conditions that require transmission access for other } \\
\text { utilities-precursor of program to open transmission networks. }\end{array}$ \\
\hline 1989 & $\begin{array}{l}\text { Shippingport becomes first nuclear plant in world to } \\
\text { be decommissioned to "greenfield" condition. } \\
\text { Series on EMF by P. Brodeur begins in New Yorker } \\
\text { (USA). }\end{array}$ & $\begin{array}{l}\text { Long Island Lighting sells Shoreham nuclear plant to state: } \\
\text { first completed and commissioned nuclear plant to be } \\
\text { abandoned without commercial operation. }\end{array}$ \\
\hline 1990 & & $\begin{array}{l}\text { Clean Air Act amendments mandate additional pollution } \\
\text { controls. } \\
\text { Nonutility generation reaches record level. }\end{array}$ \\
\hline 1992 & & National Energy Policy Act. \\
\hline
\end{tabular}


Table B1. Historical Chronology of Energy-Related Milestones, 1800-1994 (Continued)

\begin{tabular}{c|l|l}
\hline Year & \multicolumn{1}{|c|}{ Technological } & \multicolumn{1}{c}{ Institutional USA and Canada } \\
\hline 1993 & $\begin{array}{l}\text { Commercial production of variable speed wind } \\
\text { turbine begins (USA). }\end{array}$ & $\begin{array}{l}\text { TransAlta, largest investor-owned utility in Canada, files for } \\
\text { unbundled rates that would allow retail wheeling if approved. } \\
\text { Credit agencies tighten bond rating standards to reflect } \\
\text { increasing competition and risk in electric utility business. }\end{array}$ \\
\hline 1994 & $\begin{array}{l}\text { California PUC launches inquiry into the structure of utilities, } \\
\text { proposes retail wheeling as a possible outcome in a phased } \\
\text { transition. } \\
\text { Michigan launches multi-year retail wheeling experiment. } \\
\text { FPL Group cuts dividend, possibly the first electric utility to } \\
\text { reduce dividend as a matter of financial policy rather than } \\
\text { from financial necessity. }\end{array}$ \\
\hline
\end{tabular}

Source: This table is from America's Electric Utilities: Past, Present and Future, 5th edition by Leonard S. Hyman. Reprinted with special permission by Public Utilities Reports, Inc., Vienna, Virginia. Copyright 1995 by Public Utilities Reports, Inc. Additional photocopying prohibited. 

Appendix C

Statistical Tables

for the

Electric Power Industry 


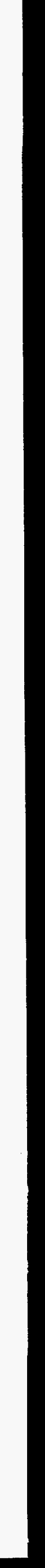




\section{Appendix C}

\section{Statistical Tables for the Electric Power Industry}

Table C1. Nameplate Capacity at Utilities by Class of Ownership, 1995

(Gigawatts)

\begin{tabular}{|c|c|}
\hline \multicolumn{2}{|l|}{ Class of Ownership } \\
\hline Investor-Owned $\ldots \ldots \ldots \ldots \ldots \ldots \ldots \ldots \ldots \ldots$ & 557.3 \\
\hline Federal $\ldots \ldots \ldots \ldots \ldots \ldots \ldots \ldots \ldots \ldots \ldots$ & 66.7 \\
\hline Other Publicly Owned ${ }^{a} \ldots \ldots \ldots \ldots \ldots \ldots \ldots$ & 88.1 \\
\hline Cooperative $\ldots \ldots \ldots \ldots \ldots \ldots \ldots \ldots \ldots \ldots \ldots \ldots$ & 33.1 \\
\hline Other $^{b} \ldots \ldots \ldots \ldots \ldots \ldots \ldots \ldots \ldots \ldots \ldots \ldots \ldots$ & 5.4 \\
\hline Total $\ldots \ldots \ldots \ldots \ldots \ldots$ & 750.5 \\
\hline
\end{tabular}

${ }^{a}$ The Other Publicly Owned category includes utilities owned by States, municipalities, and other political subdivisions (i.e., districts or public agencies).

bOther is capacity that is operated by a utility for an owner that is not a utility.

Notes: -Nameplate capacity is used for comparison to nonutilities, instead of the more commonly used net summer capability, because net summer capability is not collected for nonutilities. -Sum of components may not equal total due to independent rounding.

Source: Energy Information Administration, Inventory of Power Plants in the United States 1995, DOE/EIA-0095(95) (Washington, DC, December 1996), Table E3.

Table C2. Nameplate Capacity at Nonutlities by Type of Facility and Major Industry Group, 1995 (Gigawatts)

\begin{tabular}{|c|c|c|c|}
\hline \multicolumn{2}{|l|}{ Type of Facillity } & \multicolumn{2}{|l|}{ Maior Industry Group ${ }^{\mathrm{a}}$} \\
\hline Cogenerator Qualifying Facility & 42.3 & Manufacturing & \\
\hline Small Power Producer & & Chemical & 15.5 \\
\hline Qualifying Facility ......... & 9.7 & Paper & 11.9 \\
\hline Exempt Wholesale Generator & 2.4 & Petroleum Refining & 6.4 \\
\hline \multirow[t]{2}{*}{ Two or more of the above $\ldots \ldots \ldots \ldots$} & 3.5 & Other Manufacturing $\quad \ldots \ldots \ldots \ldots \ldots$ & 13.7 \\
\hline & & Electric, Gas, and Sanitary Services ...... & 14.9 \\
\hline Cogenerator Non-Qualifying Facility . ..... & 6.9 & Mining $\quad \ldots \ldots \ldots \ldots \ldots \ldots \ldots \ldots \ldots \ldots$ & 3.4 \\
\hline Noncogenerator Non-Qualifying Facility ... & 5.5 & Other Industries $\quad \ldots \ldots \ldots \ldots \ldots \ldots \ldots$ & 4.4 \\
\hline Total ............ & 70.3 & Total .. & 70.3 \\
\hline
\end{tabular}

The classification system used is the Standard Industrial Classification (SIC).

Notes: : Sum of components may not equal total due to independent rounding. $\cdot$ Nonutility data are for facilities of 1 megawatt or more.

Source: Energy Information Administration, Form EIA-867, "Annual Nonutility Power Producer Report," (1995). 
Table C3. Planned Nameplate Capacity Additions in 1995 by Prime Mover and Type of Facility for the Electric Power Industry, 1996-1999 (Gigawatts)

\begin{tabular}{|c|c|}
\hline \multicolumn{2}{|l|}{ Nonutility } \\
\hline \multicolumn{2}{|l|}{ Prime Mover } \\
\hline Fossil Steam (Fluidized Bed) $\ldots \ldots \ldots \ldots \ldots \ldots \ldots \ldots \ldots$ & 0.4 \\
\hline Fossil Steam (Other) & 1.5 \\
\hline Combustion Turbine $\ldots \ldots \ldots \ldots \ldots \ldots \ldots \ldots \ldots \ldots$ & 2.6 \\
\hline 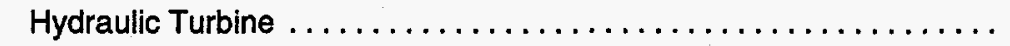 & 1.3 \\
\hline 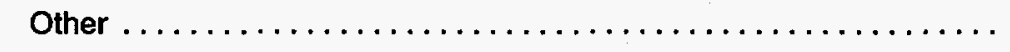 & 0.2 \\
\hline Total $\ldots \ldots \ldots \ldots \ldots \ldots \ldots$ & 6.0 \\
\hline \multicolumn{2}{|l|}{ Type of Facility } \\
\hline Cogenerator Qualifying Facility ... & 2.4 \\
\hline \multicolumn{2}{|l|}{ Small Power Producer } \\
\hline Qualifying Facility $\ldots$ & 0.4 \\
\hline Exempt Wholesale Generator .... & 0.8 \\
\hline Two or more of the above ........ & 0.7 \\
\hline Cogenerator Non-Qualifying Facility $\ldots \ldots \ldots \ldots \ldots \ldots \ldots$ & 0.3 \\
\hline Noncogenerator Non-Qualifying Facility .... & 1.4 \\
\hline Total $\ldots \ldots \ldots \ldots \ldots \ldots$ & 6.0 \\
\hline \multicolumn{2}{|l|}{ Utility } \\
\hline \multicolumn{2}{|l|}{ Prime Mover } \\
\hline Combustion (Gas) Turbine . . . . . & 9.6 \\
\hline Combined Cycle ............. & 2.7 \\
\hline 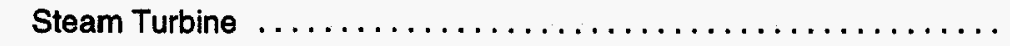 & 1.6 \\
\hline Nuclear $\ldots \ldots \ldots \ldots \ldots \ldots$ & 1.3 \\
\hline$\ldots \ldots \ldots \ldots \ldots \ldots$ & 0.6 \\
\hline 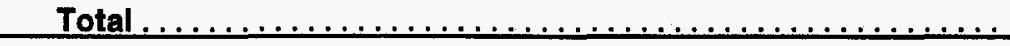 & 15.8 \\
\hline
\end{tabular}

${ }^{a}$ Other includes hydraulic turbines, internal combustion, jet engine, and wind turbine.

Notes: -Nonutility data are for facilities of 1 or more megawatts. •Planned capacity additions do not mean the same thing for utilities that they do for nonutilities. For utilities, a planned unit must be "utility authorized." For nonutilities, a planned unit must have obtained either (1) all environmental and regulatory approvals, (2) a signed contract for the electric energy, or (3) financial closure on the facility. - Indefinitely postponed and canceled units are not included. Because nonutility facilities generally have needed shorter lead times to finance and build than utility facilities, and because utilities are required to plan for future load, nonutility plans for facilities are likely to be less comprehensive than those for utilities, especially for later years. -Nameplate capacity is used for comparison to nonutilities, instead of the more commonly used net summer capability, because net summer capability is not collected for nonutilities. -Sum of components may not equal total due to independent rounding.

Source: Utllity Data: Energy Information Administration, Form E|A-860, "Annual Electric Generator Report," (1995). Nonutility Data: Energy Information Administration, Form ElA-867, "Annual Nonutility Power Producer Report," (1995). 
Table C4. Capacity and Generation Statistics for the Electric Power Industry, 1995

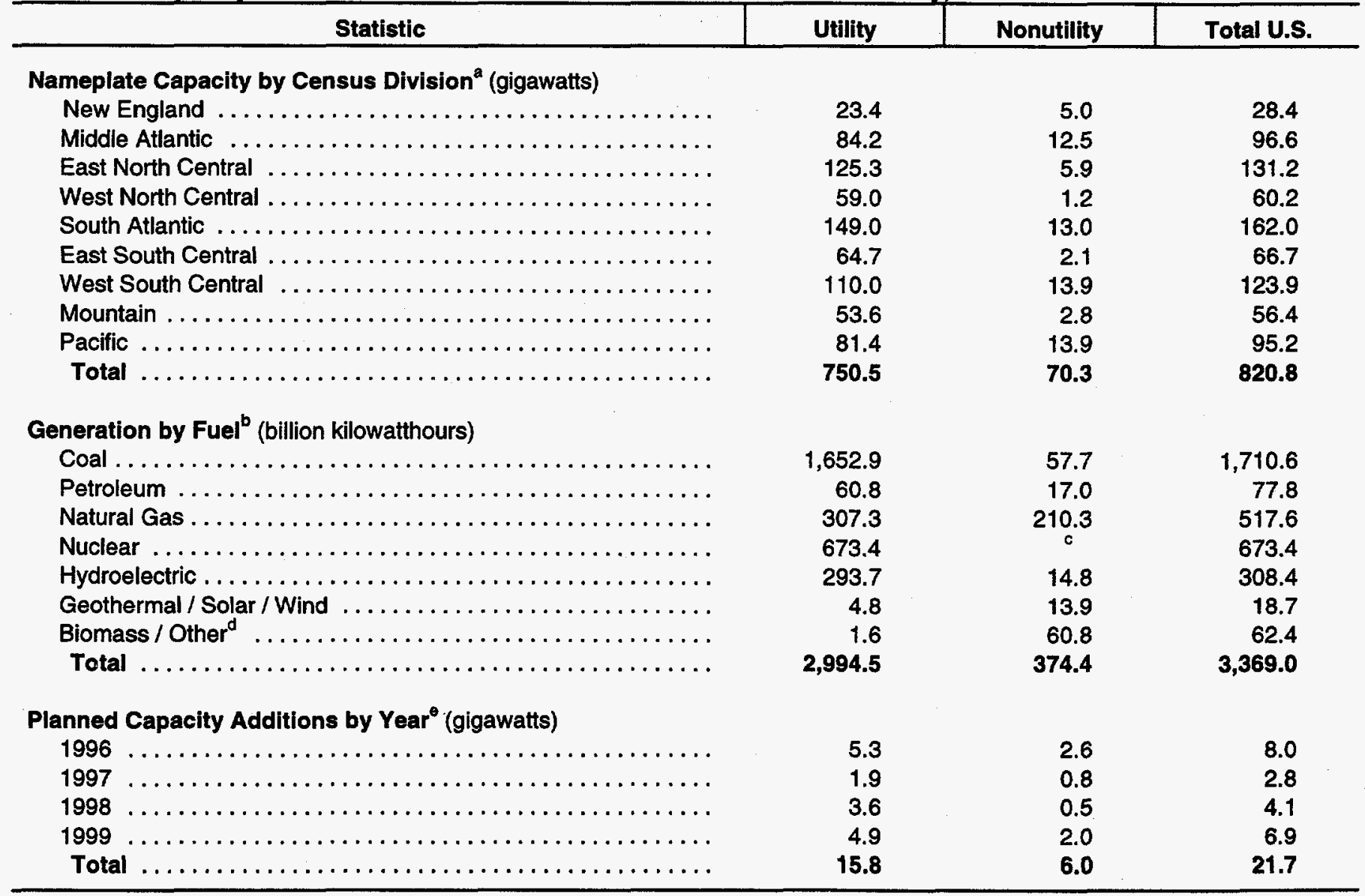

a Nameplate capacity is used instead of the more commonly used net summer capability because net summer capability is not collected for nonutilities.

${ }^{b}$ Generation for utilities is net of plant use and for nonutilities is gross generation.

Nuclear generation for nonutilities is included in the Other category.

Includes wood, wood waste, peat, wood liquors, railroad ties, pitch, wood sludge, municipal solid waste, agricultural waste, straw, tires, landfill gases, tall oil, digester gas, other waste, hydrogen, sulfur, batteries, chemicals, fish oil and spent sulfite liquor. Also includes nuclear for nonutilities.

OFor nonutilities, a planned unit must have obtained (1) all environmental and regulatory approvals, (2) a signed contract for the electric energy, or (3) financial closure on the facility. Because nonutility facilities generally have needed shorter leadtimes to finance and build than utility facilities, and because utilities are required to plan for future load, nonutility plans for facilities are likely to be less comprehensive than those for utilities, especially for later years. For utilities, a planned unit must only be "utility authorized."

Note: -Sum of components may not equal total due to independent rounding. - Nonutility data are for facilities of 1 or more megawatts. Indefinitely postponed and cancelled units are not included in planned capacity additions. •Nonutility combined cycle units are included with their constituent prime movers.

Source: Utility Data: Capacity by Census Division and Planned Capacity Additions, Energy Information Administration, Inventory of Power Plants in the United States 1995, DOE/EIA-0095(95) (Washington, DC, December 1996), Tables 16 and 7, respectively. Generation by Fuel, Energy Information Administration, Electric Power Annual 1995, Volume I, DOE/EIA-0348(95)/1 (Washington, DC, July 1996), Table 8. Nonutility Data: Capacity by Census Division and Generation by Fuel, Energy Information Administration, Electric Power Annual 1995, Volume II, DOE/EIA-0348(95)/2 (Washington, DC, December 1996), Tables 54 and 58 , respectively. Planned Capacity Additions, Energy Information Administration, Form EIA-867, "Annual Nonutility Power Producer Report," (1995). 
Table C5. Electric Power Industry Generation by Census Division and State, 1995 (Billion Kilowatthours)

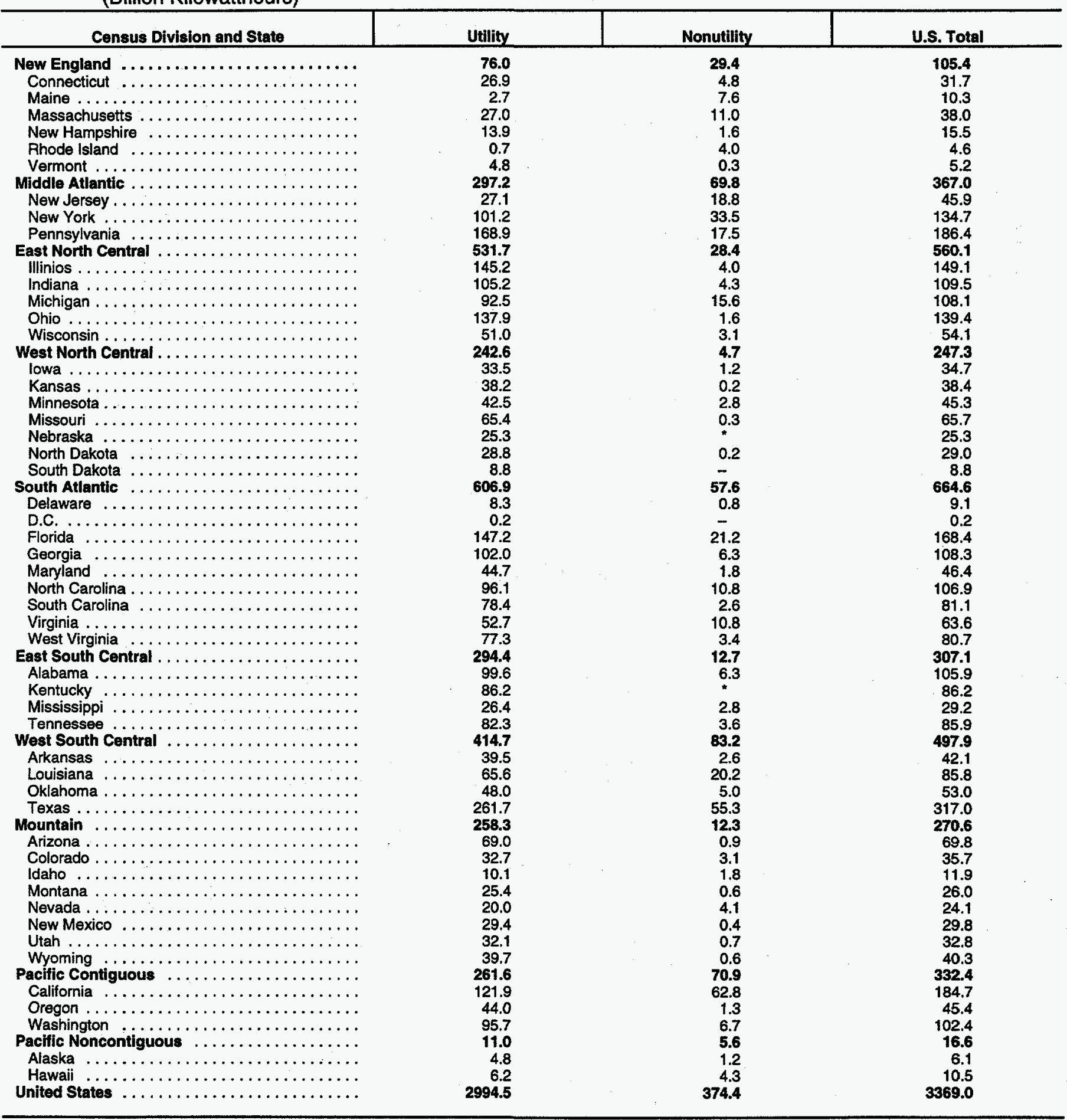

*Number less than 0.05 rounded to zero.

$-=$ Not applicable. (There are no nonutility generators in South Dakota or the District of Columbia.)

Notes: -Sum of components may not equal total due to independent rounding. -Nonutility data are for facilities of 1 or more megawatts.

Source: Utility Generation: Energy Information Administration, Electric Power Annual 1995,Volume 1, DOE/EIA-0348(95)/1 (Washington, DC, July 1996), Table 9. Nonutility Generation: Energy Information Administration, Electric Power Annual 1995, Volume II, DOE/EIA-0348(95)/2 (Washington, DC, December 1996), Tables 58 and 59. 
Table C6. Statistics of the Utillity Sector of the Electric Power Industry, 1970-1995

\begin{tabular}{|c|c|c|c|c|c|c|c|c|c|c|c|c|c|}
\hline \multirow[b]{2}{*}{ Year } & & \multirow[b]{2}{*}{$\begin{array}{c}\text { Nameplate } \\
\text { Capacity } \\
\text { (gigawatts) }\end{array}$} & \multirow[b]{2}{*}{$\begin{array}{c}\text { Generation } \\
\text { (billion } \\
\text { kilowatthours) }\end{array}$} & \multicolumn{6}{|c|}{$\begin{array}{l}\text { Generation by Fuel } \\
\text { (billion kilowatthours) }\end{array}$} & \multicolumn{3}{|c|}{$\begin{array}{l}\text { Fossil Fuel Prices } \\
\text { (dollars per million Btu) }\end{array}$} & \multirow[b]{2}{*}{$\begin{array}{l}\text { Retall Price } \\
\text { (cents per } \\
\text { kilowatthour) }\end{array}$} \\
\hline & & & & Coal & Nuclear & $\begin{array}{c}\text { Natural } \\
\text { Gas }\end{array}$ & Petroleum & $\begin{array}{l}\text { Hydro- } \\
\text { electric } \\
\end{array}$ & Otherd & Coal & Petroleum & $\begin{array}{c}\text { Natural } \\
\text { Gas }\end{array}$ & \\
\hline 1970 & $\ldots \ldots \ldots \ldots$ & 341.6 & 1,532 & 704 & 22 & 373 & 184 & 248 & 1 & 0.31 & 0.41 & 0.28 & 1.7 \\
\hline 1971 & $\ldots \ldots \ldots \ldots$ & 368.9 & 1,613 & 713 & 38 & 374 & 220 & 266 & 1 & 0.36 & 0.57 & 0.31 & 1.8 \\
\hline 1972 & $\ldots \ldots \ldots \ldots$ & 398.6 & 1,750 & 771 & 54 & 376 & 274 & 273 & 2 & 0.38 & 0.64 & 0.33 & 1.9 \\
\hline 1973 & $\ldots \ldots \ldots \ldots$ & 442.4 & 1,861 & 848 & 83 & 341 & 314 & 272 & 2 & 0.41 & 0.78 & 0.35 & 2.0 \\
\hline 1974 & $\ldots \ldots \ldots$ & 477.6 & 1,867 & 828 & 114 & 320 & 301 & 301 & 3 & 0.71 & 1.87 & 0.49 & 2.5 \\
\hline 1975 & $\ldots \ldots \ldots$ & 508.3 & 1,918 & 853 & 173 & 300 & 289 & 300 & 3 & 0.82 & 1.99 & 0.75 & 2.9 \\
\hline 1976 & $\ldots \ldots \ldots \ldots$ & 531.0 & 2,038 & 944 & 191 & 295 & 320 & 284 & 4 & 0.85 & 1.95 & 1.03 & 3.1 \\
\hline 1977 & $\ldots \ldots \ldots \ldots$ & 560.2 & 2,124 & 985 & 251 & 306 & 358 & 220 & 4 & 0.95 & 2.19 & 1.29 & 3.4 \\
\hline 1978 & $\ldots \ldots \ldots \ldots$ & 579.2 & 2,206 & 976 & 276 & 305 & 365 & 280 & 3 & 1.12 & 2.13 & 1.43 & 3.7 \\
\hline 1979 & $\ldots \ldots \ldots$ & 598.3 & 2,247 & 1,075 & 255 & 329 & 304 & 280 & 4 & 1.22 & 2.98 & 1.74 & 4.0 \\
\hline 1980 & $\ldots \ldots \ldots \ldots$ & 613.5 & 2,286 & 1,162 & 251 & 346 & 246 & 276 & 6 & 1.35 & 4.25 & 2.20 & 4.7 \\
\hline 1981 & .......... & 634.8 & 2,295 & 1,203 & 273 & 346 & 206 & 261 & 6 & 1.53 & 5.32 & 2.80 & 5.5 \\
\hline 1982 & $\ldots \ldots \ldots \ldots$ & 650.1 & 2,241 & 1,192 & 283 & 305 & 147 & 309 & 5 & 1.65 & 4.83 & 3.37 & 6.1 . \\
\hline 1983 & $\ldots \ldots \ldots \ldots$ & 658.2 & 2,310 & 1,259 & 294 & 274 & 144 & 332 & 6 & 1.66 & 4.60 & 3.47 & 6.3 \\
\hline 1984 & $\ldots \ldots \ldots$ & 672.1 & 2,416 & 1,342 & 328 & 297 & 120 & 321 & 9 & 1.66 & 4.82 & 3.58 & 6.3 \\
\hline 1985 & $\ldots \ldots \ldots$ & 698.1 & 2,470 & 1,402 & 384 & 292 & 100 & 281 & 11 & 1.65 & 4.24 & 3.43 & 6.4 \\
\hline 1986 & $\ldots \ldots \ldots$ & 707.7 & 2,487 & 1,386 & 414 & 249 & 137 & 291 & 12 & 1.58 & 2.42 & 2.35 & 6.4 \\
\hline 1987 & $\ldots \ldots \ldots$ & 718.1 & 2,572 & 1,464 & 455 & 273 & 118 & 250 & 12 & 1.51 & 2.97 & 2.24 & 6.4 \\
\hline 1988 & $\ldots \ldots \ldots \ldots$ & 723.9 & 2,704 & 1,541 & 527 & 253 & 149 & 223 & 12 & 1.47 & 2.41 & 2.26 & 6.4 \\
\hline 1989 & $\ldots \ldots \ldots$ & 730.9 & 2,784 & 1,554 & 529 & 267 & 158 & 265 & 11 & 1.45 & 2.85 & 2.36 & 6.5 \\
\hline 1990 & $\ldots \ldots \ldots \ldots$ & 735.1 & 2,808 & 1,560 & 577 & 264 & 117 & 280 & 11 & 1.45 & 3.30 & 2.32 & 6.6 \\
\hline 1991 & $\ldots \ldots \ldots \ldots$ & 740.0 & 2,825 & 1,551 & 613 & 264 & 111 & 276 & 10 & 1.45 & 2.46 & 2.15 & 6.7 \\
\hline 1992 & $\ldots \ldots \ldots$ & 741.7 & 2,797 & 1,576 & 619 & 264 & 89 & 240 & 10 & 1.41 & 2.47 & 2.33 & 6.8 \\
\hline 1993 & $\ldots \ldots \ldots \ldots$ & 744.7 & 2,883 & 1,639 & 610 & 259 & 100 & 265 & 10 & 1.39 & 2.36 & 2.56 & 6.9 \\
\hline 1994 & $\ldots \ldots$ & 746.0 & 2,911 & 1,635 & 640 & 291 & 91 & 244 & 9 & 1.36 & 2.41 & 2.23 & 6.9 \\
\hline 1995 &....$\ldots$ & 750.5 & 2,995 & 1,653 & 673 & 307 & 61 & 294 & 6 & 1.32 & 2.59 & 1.98 & 6.9 \\
\hline
\end{tabular}

a Nameplate capacity is used for comparison to nonutilities, instead of the more commonly used net summer capability, because net summer capability is not collecled for nonutilities.

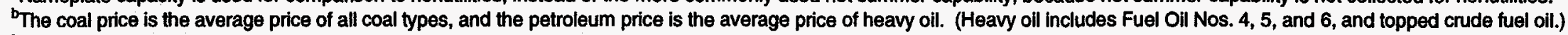

CRetail price of electricty sold by electric utillites. Data for 1979 and earlier are for Classes A and B privately owned electric utilities only; data for 1980 and forward are for selected Class A utilities whose electric operating revenues were $\$ 100$ million or more during the previous year.

'Other Includes geothermal, solar, wind, waste, and wood.

Note: •Sum of components may not equal total due to independent rounding. $\bullet$ Retall price for 1995 is preliminary.

Sources: Capacity: 1970-1981-Energy Information Administration, 1982 Annual Energy Review, DOE/EIA-0384(82) (Washington, DC, April 1983), p. 159. 1982-1995-Energy Information Administration, Inventory of Power Plants in the United States 1995, DOE/EIA-0095(95) (Washington, DC, December 1996), Table 1, and previous issues. Generation: 1970-1994-Energy Information Administration Annual Eneroy Review 1995, DOE/ElA-0384(95) Washington, DC, July 1996). Table 8.3. 1995-Energy Information Administration, Electric Power Annual 1995, Volume I, DOE/EIA-0348(95)/1 (Washington, DC; July 1996), Table 8. Fuel Prices: 1970-1990-Energy Information Administration, State Energy Price and Expenditure Data System, 1992. 19911995-Federal Energy Regulatory Commission, FERC Form 423, "Monthly Report of Cost and Quality of Fuels for Electric Plants." Retail Price: Energy Information Administration, Annual Energy Review 1995, DOE/EIA-0384(95) (Washington, DC, July 1996), Table 8.11. 


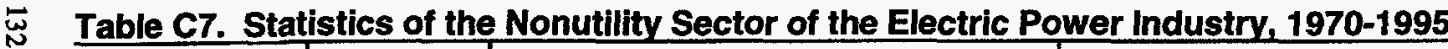

\begin{tabular}{|c|c|c|c|c|c|c|c|c|c|c|c|c|}
\hline \multirow{2}{*}{\multicolumn{2}{|c|}{ Year }} & \multirow{2}{*}{$\begin{array}{l}\text { Nameplate } \\
\text { Capacity } \\
\text { (gigawatts) }\end{array}$} & \multicolumn{3}{|c|}{$\begin{array}{c}\text { Generation } \\
\text { (billion kilowatthours) }\end{array}$} & \multicolumn{4}{|c|}{$\begin{array}{l}\text { Generation by Fuel } \\
\text { (billion kilowatthours) }\end{array}$} & \multicolumn{3}{|c|}{$\begin{array}{l}\text { Fossil Fuel Prices } \\
\text { (dollars per million Btu) }\end{array}$} \\
\hline & & & Total & $\begin{array}{c}\text { Nonutility } \\
\text { Use }\end{array}$ & $\begin{array}{l}\text { Dellveries to } \\
\text { Utilities }^{\mathrm{b}}\end{array}$ & Coal & Natural Gas & $\begin{array}{c}\text { Renewable }^{c} / \\
\text { Waste }\end{array}$ & Other ${ }^{d}$ & $\mathrm{Coal}^{\mathrm{e}}$ & Petroleum ${ }^{f}$ & Natural Gas ${ }^{9}$ \\
\hline \multirow{3}{*}{$\begin{array}{c}Y \\
1970^{h} \\
1971 \\
1972\end{array}$} & $\ldots \ldots$ & 19 & 108 & NA & NA & NA & NA & NA & NA & 0.44 & 0.46 & 0.38 \\
\hline & ....... & 19.3 & 103.2 & NA & NA & NA & NA & NA & NA & 0.47 & 0.62 & 0.41 \\
\hline & $\ldots . .$. & 18.8 & 104.5 & NA & NA & NA & NA & NA & NA & 0.51 & 0.60 & 0.46 \\
\hline 1973 & ....... & 19.4 & 102.6 & NA & NA & NA & NA & NA & NA & 0.53 & 0.73 & 0.50 \\
\hline 1974 & ....... & 19.4 & 101.6 & NA & NA & NA & NA & NA & NA & 0.99 & 1.82 & 0.67 \\
\hline 1975 & ....... & 19.2 & 85.3 & NA & NA & NA & NA & NA & NA & 1.28 & 1.91 & 0.95 \\
\hline 1976 & $\ldots \ldots$ & 19.1 & 87.1 & NA & NA & NA & NA & NA & NA & 1.25 & 1.90 & 1.21 \\
\hline 1977 & ....... & 19.2 & 87.5 & NA & NA & NA & NA & NA & NA & 1.31 & 2.15 & 1.48 \\
\hline 1978 & ....... & 19.4 & 79.0 & NA & NA & NA & NA & NA & NA & 1.46 & 2.12 & 1.66 \\
\hline 1979 & ....... & 17.4 & 71.3 & NA & NA & NA & NA & NA & NA & 1.55 & 2.76 & 1.96 \\
\hline $1985^{h}$ & $\ldots .$. & 22.9 & 98.5 & 70.2 & 28.3 & 18.2 & 33.6 & 39.7 & 7.1 & 1.81 & 4.24 & 3.87 \\
\hline 1986 & $\ldots \ldots$ & 25.3 & 112.0 & 71.3 & 40.7 & 20.5 & 40.0 & 46.0 & 5.5 & 1.75 & 2.51 & 3.20 \\
\hline 1987 & $\ldots \ldots$ & 30.0 & 146.6 & 94.0 & 52.6 & 22.3 & 56.8 & 53.5 & 14.0 & 1.64 & 2.87 & 2.88 \\
\hline 1988 & $\ldots . .$. & 33.7 & 174.3 & 104.1 & 70.2 & 31.9 & 70.0 & 67.2 & 5.1 & 1.61 & 2.34 & 2.90 \\
\hline $1989^{h}$ & ..... & 36.6 & 187.4 & 106.1 & 81.2 & 31.5 & 98.9 & 49.4 & 7.5 & 1.61 & 2.75 & 2.93 \\
\hline 1990 & ....... & 42.9 & 217.2 & 111.0 & 106.2 & 32.1 & 116.7 & 58.2 & 10.2 & 1.63 & 3.10 & 2.95 \\
\hline 1991 & ....... & 48.2 & 248.4 & 119.3 & 129.1 & 40.6 & 131.3 & 65.0 & 11.5 & 1.62 & 2.44 & 2.80 \\
\hline $1992^{h}$ & $\ldots \ldots$ & 56.8 & 296.0 & 131.6 & 164.4 & 47.4 & 158.8 & 75.3 & 14.5 & 1.62 & 2.46 & 2.91 \\
\hline 1993 & $\ldots . .$. & 60.8 & 325.2 & 137.8 & 187.5 & 53.4 & 174.3 & 81.0 & 16.6 & 1.59 & 2.41 & 3.15 \\
\hline 1994 & ....... & 68.5 & 354.9 & 150.2 & 204.7 & 59.0 & 192.2 & 85.0 & 18.6 & NA & NA & NA \\
\hline 1995 & ........ & 70.3 & 374.4 & 157.9 & 216.5 & 57.7 & 210.3 & 85.7 & 20.8 & NA & NA & NA \\
\hline
\end{tabular}

${ }^{a}$ Consumed onsite by the nonutility or delivered to other nonutilities.

Deliveries to utilities for resale.

'Renewable energy sources include hydroelectric, wind, solar, geothermal, and wood resources.

dOther includes all other fuels, including petroleum, multiple unit projects for which the primary energy source varied among the units, and projects which did not identity their primary energy source.

The coal price is the price of steam coal to the industrial sector.

'The petroleum price is the price of residual fuel oil to the industrial sector.

The natural gas price is its price to the industrial sector.

"These data series were compiled from several sources resulting in some inconsistancies in category definitior.s over time. 1980-1984 are not included because nonutility data were not collected for those years. Nonutility data for 1970 through 1979 represent capacity and generation in the industrial sector for plants of 10 megawatts or more only. Nonutility data for 1985 through 1988 include all nonutilities. Nonutility data for 1989 through 1991 include nonutility facilities of 5 or more megawatts. Nonutility data for 1992 through 1995 include nonutility facilities of 1 or more megawatts. Sum of components may not equal total due to independent rounding. Breakdown of generation assumes no nonutility receipts from utilities are resold to utilities.

' 1970 nonutility capacity and generation data are available to whole numbers only.

NA = Not available

Notes: SSum of components may not equal total due to independent rounding -Breakdown of generation assumes no nonutility receipts are resold.

Sources: Capacity and Generation: 1970-1979-Federal Power Commission, Form 4, "Monthly Power Plant Report." 1985-1988-Edison Electric Institute, Statistical Yearbook of the Electric Utility Industry/1991 (Washington, DC, November 1992), pp. 7 and 15. 1989-1995-Energy Information Administration, Electric Power Annual 1995, Volume II, DOE/EIA-0348(95)/2 (Washington, DC, December 1996), Tables 52, 54, and 58, and preceeding issues, and Form ElA-867, “Annual Nonutility Power Producer Report." Generation by Fuel: 1985-1986-Edison Electric Institute, 1986 Capacity and Generation of Non-Utility Sources of Energy (Washington, DC, July 1988), pp. 78 and 79. 1987-1988-Edison Electric Institute, 1988 Capacity and Generation of Non-Utility Sources of Energy (Washington, DC, December 1989), pp. 55 and 56. 1989-1995-Energy Information Administration, Electric Power Annual 1995, Volume II, DOE/EIA-0348(95)/2 (Washington, DC, December 1996), Table 58 and preceeding issues. Fuel Prices: 1970-1984-Energy Information Administration, State Energy Price and Expenditure Data System, 1992. 1985-1993-Energy Information Administration, Annual Energy Review 1995, DOE/EIA-0384(95) (Washington, DC, July 1996), Table 3.7. 
Table C8. Average Nameplate Capacity and Number of Utility-Operated Coal-Fired Steam Turbine Units by Historical or Planned Year of Commercial Operation, 1970-2005

\begin{tabular}{|c|c|c|}
\hline Year & $\begin{array}{c}\text { Average Capacity } \\
\text { (Megawatts) }\end{array}$ & Number of Units \\
\hline $1970 \ldots \ldots \ldots \ldots \ldots \ldots \ldots \ldots \ldots \ldots$ & 361.7 & 34 \\
\hline $1971 \ldots \ldots \ldots \ldots \ldots \ldots \ldots \ldots \ldots \ldots$ & 524.8 & 25 \\
\hline $1972 \ldots \ldots \ldots \ldots \ldots \ldots \ldots \ldots \ldots \ldots$ & 453.5 & 28 \\
\hline $1973 \ldots \ldots \ldots \ldots \ldots \ldots \ldots \ldots \ldots \ldots$ & 566.9 & 29 \\
\hline $1974 \ldots \ldots \ldots \ldots \ldots \ldots \ldots \ldots \ldots \ldots \ldots$ & 600.6 & 21 \\
\hline 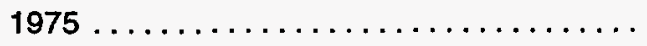 & 600.7 & 18 \\
\hline $1976 \ldots \ldots \ldots \ldots \ldots \ldots \ldots \ldots \ldots$ & 456.8 & 20 \\
\hline $1977 \ldots \ldots \ldots \ldots \ldots \ldots \ldots \ldots \ldots \ldots \ldots$ & 549.2 & 22 \\
\hline $1978 \ldots \ldots \ldots \ldots \ldots \ldots \ldots \ldots \ldots \ldots$ & 473.5 & 27 \\
\hline $1979 \ldots \ldots \ldots \ldots \ldots \ldots \ldots \ldots \ldots \ldots$ & 469.3 & 22 \\
\hline $1980 \ldots \ldots \ldots \ldots \ldots \ldots \ldots \ldots \ldots \ldots$ & 590.7 & 26 \\
\hline $1981 \ldots \ldots \ldots \ldots \ldots \ldots \ldots \ldots \ldots$ & 454.5 & 23 \\
\hline $1982 \ldots \ldots \ldots \ldots \ldots \ldots \ldots \ldots \ldots \ldots$ & 518.1 & 21 \\
\hline $1983 \ldots \ldots \ldots \ldots \ldots \ldots \ldots \ldots \ldots \ldots$ & 454.4 & 14 \\
\hline $1984 \ldots \ldots \ldots \ldots \ldots \ldots \ldots \ldots \ldots \ldots$ & 646.0 & 16 \\
\hline 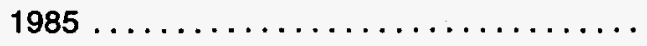 & 534.4 & 12 \\
\hline 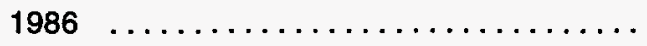 & 502.2 & 14 \\
\hline $1987 \ldots \ldots \ldots \ldots \ldots \ldots \ldots \ldots \ldots \ldots \ldots$ & 547.1 & 7 \\
\hline $1988 \ldots \ldots \ldots \ldots \ldots \ldots \ldots \ldots \ldots \ldots$ & 224.8 & 6 \\
\hline $1989 \ldots \ldots \ldots \ldots \ldots \ldots \ldots \ldots \ldots \ldots$ & 965.5 & 3 \\
\hline $1990 \ldots \ldots \ldots \ldots \ldots \ldots \ldots \ldots \ldots \ldots$ & 296.9 & 4 \\
\hline $1991 \ldots \ldots \ldots \ldots \ldots \ldots \ldots \ldots \ldots \ldots$ & 614.0 & 5 \\
\hline $1992 \ldots \ldots \ldots \ldots \ldots \ldots \ldots \ldots \ldots \ldots \ldots$ & 210.0 & 3 \\
\hline $1993 \quad \ldots \ldots \ldots \ldots \ldots \ldots \ldots \ldots \ldots \ldots$ & - & -- \\
\hline $1994 \ldots \ldots \ldots \ldots \ldots \ldots \ldots \ldots \ldots \ldots$ & -- & -- \\
\hline $1995 \ldots \ldots \ldots \ldots \ldots \ldots \ldots \ldots \ldots \ldots$ & 365.0 & 3 \\
\hline 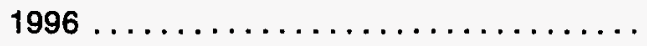 & 328.1 & 4 \\
\hline $1997 \ldots \ldots \ldots \ldots \ldots \ldots \ldots \ldots \ldots \ldots$ & -- & -- \\
\hline $1998 \ldots \ldots \ldots \ldots \ldots \ldots \ldots \ldots \ldots \ldots$ & - & - \\
\hline $1999 \ldots \ldots \ldots \ldots \ldots \ldots \ldots \ldots \ldots \ldots$ & 300.0 & 1 \\
\hline 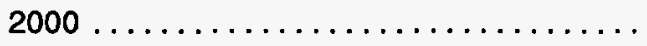 & 800.9 & 1 \\
\hline 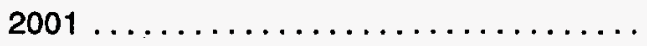 & - & -- \\
\hline 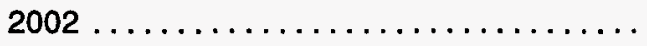 & 546.0 & 1 \\
\hline 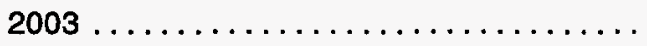 & -- & -- \\
\hline $2004 \ldots \ldots \ldots \ldots \ldots \ldots \ldots \ldots \ldots \ldots$ & 290.0 & 2 \\
\hline $2005 \ldots \ldots \ldots \ldots \ldots \ldots \ldots \ldots \ldots \ldots$ & 604.0 & 2 \\
\hline
\end{tabular}

$-=$ No new units started or, in the case of 1996 and beyond, planned to enter commercial operation. Notes: - The year of commercial operation is the year that control of the unit was turned over to the dispatcher. Includes all coal-fired steam turbine units active since 1970 and all units planned as of January 1,1996 . Indefinitely postponed and canceled units are not included in planned capacity additions.

Source: Energy Information Administration, Form EIA-860, "Annual Electric Generator Report" (1995). 
Table C9. Average Nameplate Capacity and Number of Nonutility-Owned Units by Selected Prime Mover and Historical or Planned Year that Electricity First Generated, 1970-1999

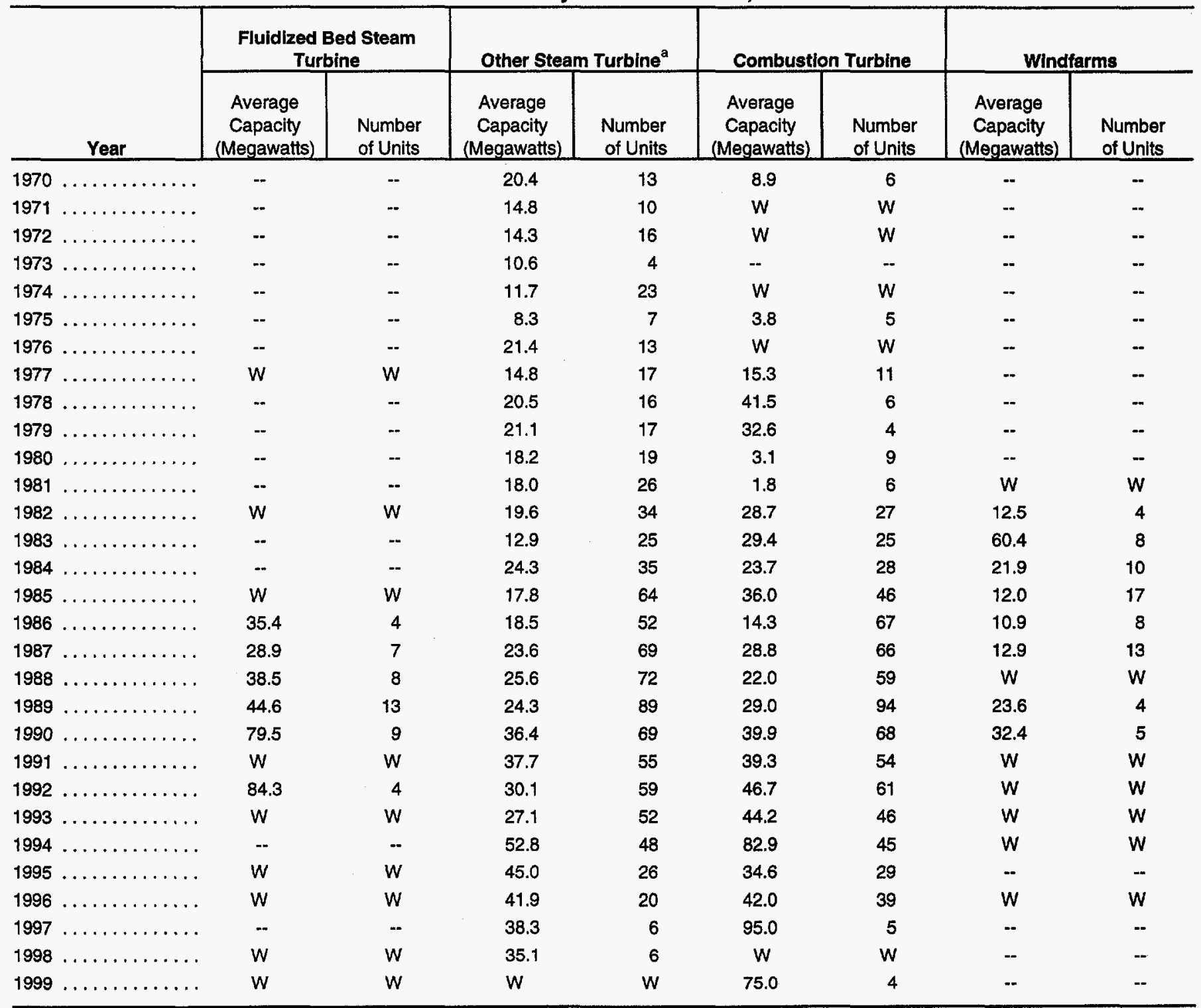

${ }^{a}$ Other steam turbine units include steam portion of combined cycle, nuclear steam, geothermal steam, and solar steam.

$W=$ Withneld to avoid disclosure of individual company data.

- = No new units started, or in the case of 1996 and beyond, planned to start operation.

Notes: $\bullet$ Combined cycle units are included with their constituent prime movers. -Data include only. units operating or planned on December 31 , 1995. Indefinitely postponed and canceled units are not included in planned capacity additions.

Source: Energy Information Administration, Form ElA-867, "Annual Nonutility Power Producer Report," (1995). 
Appendix D

Brief Characteristics of the Oak Ridge Financial Model (ORFIN) 



\section{Appendix D \\ Brief Characteristics of the Oak Ridge Financial Model (ORFIN)}

ORFIN is a simplified version of a utility integrated planning model developed by the Oak Ridge National Laboratory. The model includes a production-costing module, utility financial statements (income statement, balance sheet, and cash-flow statement), and a rate-design module (functionalization, classification, and allocation of costs to customer classes). ${ }^{259}$

ORFIN simulates a single utility interacting with a single wholesale market. The utility serves bundled retail customers through its integrated generation, transmission, and distribution system. The utility also buys and sells power on the wholesale market when economical, subject to certain system constraints, such as the utility's wholesale transmission capacity. Wheeling customers purchase electricity directly from the wholesale market but receive electricity through the utility's transmission and distribution (T\&D) network.

Figure D1 defines the boundaries of the assessment framework. To meet this framework, ORFIN contains many user inputs to permit examination of the effects of a wide variety of variables on utility production costs, assets, incomes, losses, and rates. Table D1 lists the key categories of user inputs. The user provides information on the initial state of the utility. These initial conditions include information on the utility's power plants, powerpurchase contracts, operations and maintenance (O\&M) costs, and customer characteristics. The user also specifies the initial fuel prices and wholesale prices and their escalation over time. This initial state of the utility defines the base case.

The dispatch module uses data from each year to calculate the generation, contract purchases, and wholesale-market activity (purchases and sales) for the utility. The module dispatches up to 10 distinct utility resources. These resources can be utility-owned generating units, long- term power-purchase contracts, or a new resource (a utility-owned plant or a contract). New plants may be added in small increments each year to ensure that the utility meets its designated reserve requirements. The model matches production and loads for a peak period (that includes no planned outages) and an off-peak period (where plants are derated so that their annual availability accounts for user-defined forced and planned outage rates). The production-costing results are then used by the financial portions of ORFIN to estimate O\&M expenditures.

The dispatch module first calculates load-duration curves for the peak and off-peak seasons. The resources are then sorted in order of their variable costs. Must-run plants are assigned a zero bid price for dispatching purposes. The percentage of the season a plant operates is calculated for up to 22 power levels. For each season, these 22 points are sorted by increasing power level before calculating the equivalent load duration curve for each plant.

After calculating the operating times for all plants for the year, ORFIN determines if it is economical to sell any excess power on the wholesale market or to displace some of its own production with wholesale purchases. The user defines the wholesale market using up to four wholesale prices for different portions of the year. ORFIN then compares the variable cost for each plant with the wholesale purchase and sale prices for each period. When a plant's variable cost is lower than the current wholesale sale price and the plant has excess capacity, the plant will sell into the market. When its variable costs exceed the wholesale purchase price and it is producing at that time, then ORFIN backs down the plant and, instead, purchases wholesale power. ORFIN compares each possible transaction with the user-defined transmission-capacity constraint and limits wholesale sales and purchases accordingly.

\footnotetext{
${ }^{259}$ Oak Ridge National Laboratory, ORFIN: An Electric Utility Financial and Production Simulator, ORNL/CON-431 (Oak Ridge, TN, March 1996).
} 
ORFIN's income statement reflects the results of the utility's operations for a calendar year. The income statement includes detail about revenues, expenses, and income. Income is the difference between revenues and expenses. Revenues are the product of electricity sales and prices, summed over the relevant customer classes. Operating expenses include production and nonproduction costs, book depreciation, taxes, and interest payments. Production expenses include fuel and O\&M costs for the utility's power plants, power-purchase-contract costs, and purchases and sales on the wholesale market. Net income is the return to utility shareholders.

ORFIN yields what is called a bottom-up ex ante administrative valuation of transition costs. The annual transition costs are the annual difference in net income between the retail-wheeling scenario and the base case. The total transition costs are the sum of these annual differences, discounted to present value dollars.

$$
\text { Net Income }{ }_{t}=\text { Revenues }_{t}-\text { Expenses }_{t}
$$

$\imath$ Costs $=\sum_{t=1}^{T}\left[\left(\right.\right.$ Net Income $_{b c, t}-$ Net Income Iw, $\left._{t}\right) \div\left(1+d_{1}\right.$

Transition costs are calculated as net present value at the utility's return on equity for the years $t=1$ through year $T$. Net Income $e_{r w, t}$ is from the retail wheeling case for year $t$ while Net Income $e_{b c t}$ is from the base case for the same year.

Figure D1. Schematic Representation Defining ORFIN Assessment Framework

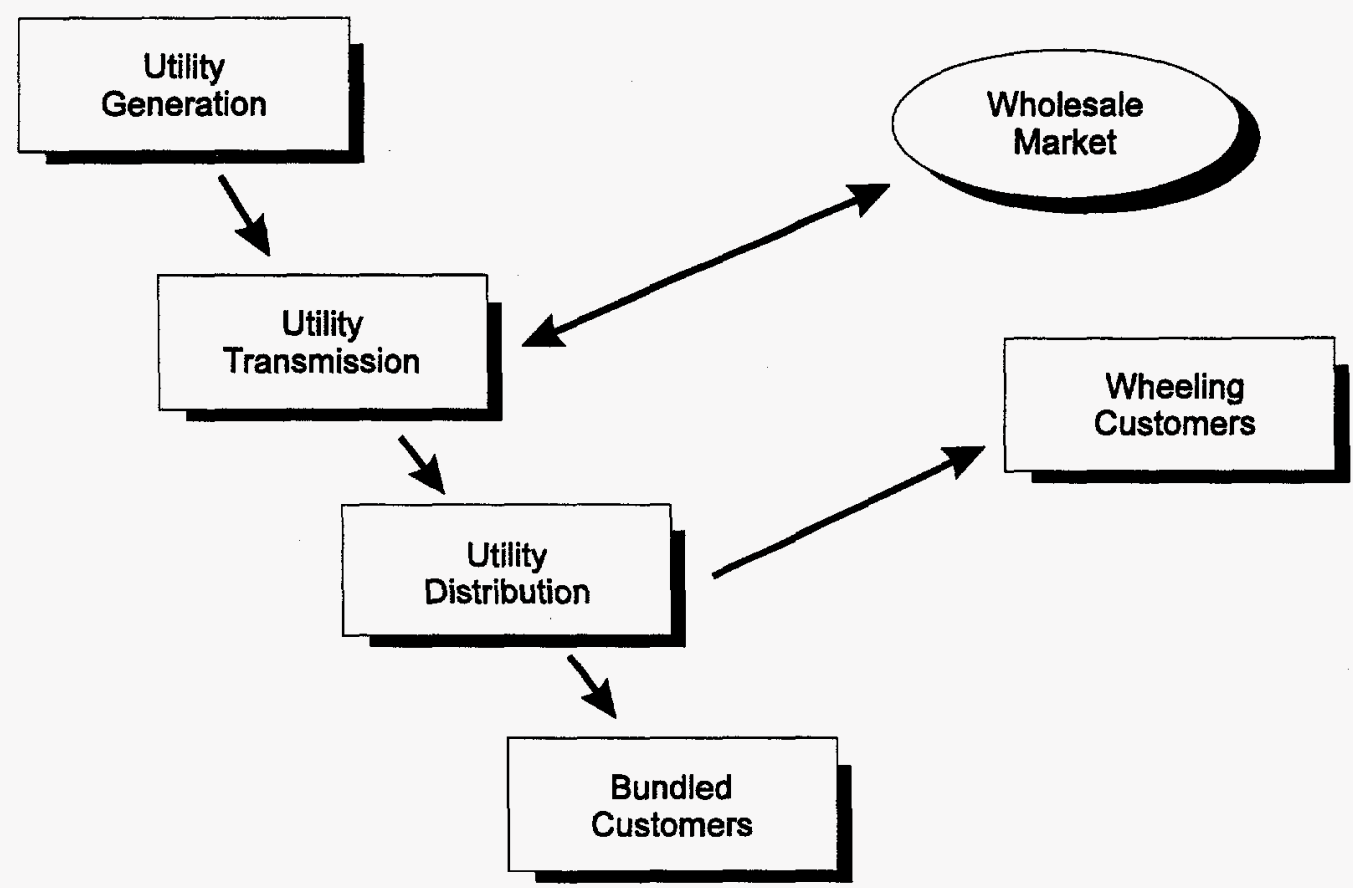

Source: Oak Ridge National Laboratory, Strategies to Address Transition Costs in the Electricity Industry, ORNL/CON-431 (Oak Ridge, TN, August 1996). 
Nongeneration operating costs

Nongeneration capital costs

Power-purchase contracts

Utility-owned generating units

Wholesale-market prices

Customers

Retail wheeling

Finances
Transmission, distribution, customer service, A\&G, O\&M (\$/year), and public-policy-program costs (\$/year), and O\&M cost escalation percent per year

Transmission, distribution, and general capital costs (\$/year, $\$ /$ customer, $\$ / k W$ )

Capacity (MW), offline date (year), forced and planned outage rates (percent), fixed costs ( $\$ / k W$-year), and variable costs (c/kWh)

Capacity (MW), initial cost ( $\$ / \mathrm{kW})$, start and offline dates (year), tax and book depreciation lives (years), forced and planned outage rates (percent), fixed O\&M cost ( $\$ / k W$-year), variable O\&M cost ( $\mathrm{c} / \mathrm{kWh})$, O\&M escalation rate (percent per year), heat rate (Btu/kWh), fuel type, and fuel prices (\$/MBtu) by year

Prices ( $(\mathrm{kWh})$ by time period (percent per year), escalation rates (percent per year), difference between wholesale purchase and sale price $(€ / \mathrm{kWh})$, and transmission capacity (MW)

By class: number of customers, consumption ( $\mathrm{kWh} /$ customermonth), load factor, growth rates (percent per year) in number of customers and in per-customer consumption, and T\&D energy and demand losses

Percentage of customers from each class that wheel by year, percentage of A\&G costs paid by wheelers, and ancillaryservice cost adder $(\phi / k W h)$

Long-term bonds and common equity (percent of total capitalization and return in percent per year), inflation rate (percent per year), federal/state income tax rate (percent), revenue-sensitive tax rate (percent), property tax rate (percent), frequency and type (historic vs future test year) of rate cases, and regulatory assets

$A \& G=$ Administrative and general.

O\&M = Operations and maintenance.

MW $=$ Megawatts.

$\$ / k W=$ Dollars per kilowatt.

$\varnothing / k W=$ Cents per kilowatt.

Btu = British thermal unit.

$\$ / \mathrm{Mbtu}=$ Dollars per million Btu.

Source: Oak Ridge National Laboratory, Strategies to Address Transition Costs in the Electricity Industry, ORNL/CON-431 (Oak Ridge, TN, August 1996). 

Appendix E

Stranded Costs 



\section{Appendix E}

\section{Stranded Costs}

\section{Methodologies for Estimating Stranded Costs}

Utilities with power production costs higher than those likely to prevail in the competitive market will be unable to fully recover the fixed costs of generating facilities that they own and operate to meet customer demand. ${ }^{260} \mathrm{Ac}-$ cordingly, the initial composition of stranded costs will be dominated by assets related to a utility's generating capacity. ${ }^{261}$

A utility can estimate its potential stranded/strandable costs in one of two basic ways. It can compute the present value of its assets and compare the resulting valuation with its sunk or historical costs, or it can look at the loss in revenue (for a given number of years in the future) as a market price for electricity changes and compute the present value of stranded costs. These basic approaches can be varied depending on when the estimates are made, i.e., before or after the commencement of wholesale and retail wheeling and whether the estimates are made administratively or are determined by the market. These varying considerations enable categorization of approaches into bottom-up versus top-down, ex ante versus ex post, and administrative versus market. ${ }^{262}$

\section{Bottom-Up Versus Top-Down}

This approach looks at whether stranded costs are estimated for individual assets or for the aggregate of assets. The bottom-up approach computes the amount of each investment (including contracts, regulatory assets, social programs, and other stranded liabilities) that would be stranded. This approach can provide valuable information (for consideration in adopting mitigation strategies) with respect to those cost variables that have critical impacts on costs. Its weakness lies in not being able to encompass certain incumbent burdens.

The top-down approach calculates the difference in revenues under a regulatory regime and those likely to accrue with the commencement of competition. ${ }^{263}$ In this approach, the totality of assets (including incumbent burdens) can be taken into account.

\section{Ex Ante Versus Ex Post}

These approaches are based on when the estimates for stranded/strandable costs are made, i.e., before or after the commencement of transition to competition.

The ex ante method provides projections (or forecasts) of stranded/strandable costs before the start of competition. It is based on embedded costs and projected market prices from alternative sources. The validity of such forecasts hinges on the legitimacy of a host of assumptions (such as fuel prices, demand growth, load shapes, technological advancements and others) incorporated in the process. ${ }^{264}$ Incorrect assumptions could lead to windfall gains or losses.

${ }^{260}$ Fixed costs represent the sum total of expenses (like interest, depreciation, taxes, and nonfuel operating and maintenance expenses) that do not vary with the level of economic activity. Long-term power purchase agreements also imply that the utilities incur long-term fixed payment obligations which they may or may not be able to meet fully in a changing market environment.

${ }^{261}$ Transmission and distribution activities will continue to be regulated.

${ }^{262}$ For a additional details of these approaches, refer to Niagara Mohawk Power Corporation's filing with the New York Public Service Commission in PSC Case Nos. 94-E-0098 and 94-E-0099, Phase II, Multi-Year Electric Rate, Restructuring and Retail Access Proposal. (Syracuse, NY, October 6, 1995). Also, San Diego Gas and Electric Company, Comments of San Diego Gas and Electric Company on Proposed Policy Governing Restructuring Electric Services Industry and Reforming Regulation, submitted to the California Public Utilities Commission in Docket No. R-94-04031 (San Diego, CA, June 8, 1994).

${ }^{263}$ The assumption is that electricity prices will decline as a result of competition.

${ }^{264}$ For example, the Massachusetts Electric Company in Massachusetts estimated the net present value of its stranded cost obligations to be about $\$ 4.3$ billion. These estimates, which were based on a set of assumptions used by the utility, were challenged in another assessment report prepared for the Massachusetts Attorney General. That report showed that the Massachusetts operations of the utility will result in large restructuring gains in the range of $\$ 1.0$ billion to $\$ 3.0$ billion. Refer to Resource Insight Inc., Estimation of Market Value, Stranded Investment and Restructuring Gains (Boston, MA: April 17, 1996), p. 2. 
The ex post approach estimates stranded/strandable costs after competition is introduced and has made a start. Since market prices are known in this approach, a greater degree of confidence can be placed in the estimates. The appeal of this approach lies in its capability to indicate the magnitude of strandable assets that move the utilities to initiate actions toward adoption of feasible mitigation strategies. In addition, the process establishes a benchmark for potential recovery.

\section{Administrative Versus Market Approach}

An administrative approach is based on negotiations between the utility and the regulatory agencies in an attempt to estimate the amount of stranded/strandable assets. However, this approach suffers from the same difficulties as the ex ante approach, in which assumptions regarding future prices and asset values need to be made. On the other hand, the market approach starts with observations in the market and minimizes the problems inherent in forecasting. Observed prices can, however, be subject to market volatility, biasing the results in the market approach.

An alternative (in the market approach) is for a utility to put its generating assets up for sale and secure a price offered by the highest bidder. Stranded costs in this approach are immediately determined as the difference between the embedded price and the realized price. Its main disadvantage is that large blocks of assets cannot be sold easily and may tend to depress prices. ${ }^{265}$ Its applicability is also limited to marketable assets.

In its recent filing with the Public Service Commission of New York, the Niagara Mohawk Power Corporation (NMPC) opted in favor of a hybrid approach for estimating strandable costs, using several of the above methods. Its preferred method will be ex ante, top-down, and administrative. Revenue projections based on a "business-as-usual" scenario will be compared with what may be sustainable under competitive conditions. NMPC will also use a bottom-up approach to identify the source of deficit. In addition, the utility proposes to make ex post adjustments to market electricity prices in an attempt to fine tune the estimates.

Table E1 provides possible combinations of the approaches discussed above.

\section{FERC's Methodology for Estimating Stranded Cost Obligations}

As indicated in an earlier chapter, FERC has adopted the "revenues lost" approach in hopes of avoiding asset-byasset reviews to calculate recoverable stranded costs. ${ }^{266}$ Whether the State regulatory authorities will also adopt this mode remains an open question. ${ }^{267}$

Table E1. Alternative Ways to Compute Stranded Commitments

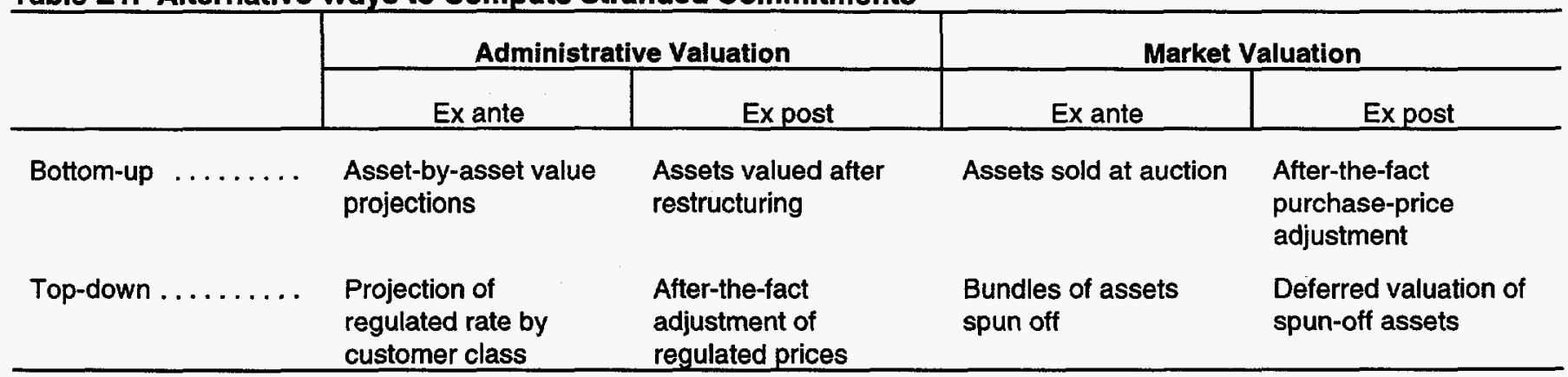

Source: Oak Ridge National Laboratory, Estimating Potential Stranded Commitments for U.S. Investor-Owned Electric Utilities, ORNL/CON-406 (Oak Ridge, TN, January 1995), p. 7.

\footnotetext{
${ }^{265}$ Boston Edison, Industry Restructuring Plan, submitted to the Massachusetts Department of Public Utilities in Docket No. 96-23 (Boston, MA, February 16, 1996).

${ }^{266}$ By adopting the "revenues lost" approach, FERC also avoided including additional categories of costs in computing stranded costs. Recommended categories for inclusion include fuel supply costs, purchased power costs (including qualifying facility costs), nuclear decommissioning costs, and such other utility obligations (such as expenditures on social and environmental programs) that may possibly be stranded.

${ }^{267}$ The Massachusetts Department of Public Utilities, for example, would prefer that the investor-owned utilities in the State take steps to mitigate stranded costs through the sale of generating assets on the presumption that while some generating assets may be undervalued (in relation to their unamortized portion of the historical costs), others may be overvalued. Adoption of this procedure will provide an opportunity to recover the net, nonmitigable stranded costs on their books as of August 16, 1995.
} 
FERC's methodology for estimating the "stranded cost obligation" (SCO) of a departing generation customer takes the following form:

RSR = revenue stream estimate attributable to the departing customer based on the average of three prior year's revenues

where

$$
\mathrm{SCO}=\quad(\mathrm{RSR}-\mathrm{CMVE}) \times \mathrm{L}
$$

$$
\begin{array}{ll}
\mathrm{SCO}= & \text { stranded cost obligation } \\
\mathrm{CMVE}= & \begin{array}{l}
\text { competitive market value estimate } \\
\text { either from sale of released capacity } \\
\text { or the average annual cost to the } \\
\text { customer of replacement capacity } \\
\text { and associated energy }
\end{array} \\
\mathrm{L}= & \begin{array}{l}
\text { length of obligation (reasonable } \\
\text { expectation period). }
\end{array}
\end{array}
$$

The above formula is designed for determining stranded costs associated with departing wholesale-generation customers and retail-turned-wholesale customers. Its application is subject to conditions such as stipulating a cap on SCO, payment options, and others. The formula is designed to ensure full recovery of legitimate, prudent, and verifiable stranded costs subject to the requirement that the utility take steps to mitigate stranded costs. In addition, the results create certainty for the departing customer as well as incentives for parties to renegotiate their existing requirements contracts. ${ }^{268}$

It is just as possible that FERC's formula approach will also raise issues in the process of estimating stranded costs. It will not be easy to estimate the CMVE based on a market analysis. Establishing that the utility had a reasonable expectation of serving the customer may also be controversial.

\section{Mitigation Strategies}

\section{Classification Schemes}

It is possible to view mitigation strategies from the perspective of whether they are transaction or nonransaction related. This is the approach adopted in a study prepared by the National Regulatory Research Institute (NRRI) as a briefing document for State commissions. The classification adopted in the NRRI study is as follows: ${ }^{269}$

\section{Transaction-Related Recovery Devices}

- Access charge tied directly to continued transmission or distribution service

- Exit fees charged to departing customers but unrelated to costs incurred on behalf of those customers

- Exit fees charged to departing customers and calculated to recover costs incurred on behalf of those customers

- A share of net generation savings realized by departing customers over time.

\section{Non-Transaction-Related Recovery Devices}

- Shifting costs to captive customers

- Charging ratepayers above-cost prices where market exceeds cost

- Accelerated and decelerated depreciation

- Price cap on performance-based rates. ${ }^{270}$

${ }^{268}$ Federal Energy Regulatory Commission, Order No 888, Promoting Wholesale Competition Through Open Access Non-discriminatory Transmission Services by Public Utilities, Docket No. RM95-8-000, and Recovery of Stranded Costs by Public Utilities and Transmitting Utilities, Docket No. RM-94-7-001 (Final Rule, April 24, 1996), pp. 593-605.

${ }^{269}$ National Regulatory Research Institute, The Regulatory Treatment of Embedded Costs Exceeding Market Prices: Transition to a Competitive Electric Generation Market-A Briefing Document for State Commissions (Columbus, OH, November 7, 1994), pp. 45-56.

${ }^{270}$ Price caps allow a utility to keep all or a share of the revenues resulting from cost-cutting efficiencies. Performance-based incentive rate-setting attempts to link profits to desired results or targets. Both mechanisms enable utilities to reduce costs and/or attain efficiency gains and do not, therefore, shift costs. 


\section{Broader Bases}

- Entrance fees charged to new generation

- All sellers pay a per-kilowatthour tax on generation

- Taxes to include credits for financial writedowns or trust funds to subsidize buyout of contracts from nonutility generators.

Each of the above 11 strategies is evaluated to determine its applicability in comparison with other strategies. The criteria used include considerations of static and dynamic efficiency, consistency with evolution to a competitive market, consistency with regulatory quid pro quo, and difficulties in implementation.

The number of suggested mitigation strategies has proliferated since the release of the FERC's declared intent to actively promote electricity competition in the wake of the EPACT. The following recent listing of 34 strategies is based on a review of the filings at FERC, restructuring proceedings, and a survey of the literature. This study classifies them into six major categories. ${ }^{271}$

\section{Market Actions}

Open Markets: Maximizes competitive pressures on electricity suppliers by ensuring a rapid transition to retail wheeling coupled with the elimination of monopoly franchises. The financial consequences of this strategy for utility shareholders are severe.

Delay Competition: Assumes the retail process to begin in a staged fashion starting with some selected customers getting access to alternative suppliers initially and extending it to others subsequently. A variant of this strategy is to give all customers access at the same time, but to delay the onset of access by several years. This strategy contrasts sharply with the preceding strategy, but reduces financial burdens on utility shareholders.
Divest Utility Plant: Envisions divestiture of a utility's generating assets to provide a readily identifiable market value for the assets and thus a valuation of its stranded costs. This strategy is deemed necessary to ensure competitive markets and to reduce potential conflicts between unregulated and regulated operations. Reduction of market power is touted as another advantage. ${ }^{272}$ Variants of the divestiture strategy include a rate-base spinoff, where the utility retains only that portion of its generation needed to serve its retail customers and sells the remainder. Another version extends divestiture to sale of transmission assets, in the belief that such assets' market value exceeds their book value, and that this may be used to offset losses resulting from the sale of generating assets at below-book market values.

Mergers: Reduces potential stranded costs by promoting operating efficiencies or improving marketing opportunities.

Market Excess Capacity or Energy: Assumes that capacity freed by departing customers can be marketed, thereby augmenting revenue accruals and lowering stranded cost estimations.

\section{Depreciation Options}

Depreciation accounting enables recovery of original plant cost over the estimated life of the plant of about 30 to 40 years. Nearly 97 percent of the utilities apply a straight-line recovery method for ratemaking purposes. ${ }^{273}$ Depreciation expenses are reflected in the prices customers pay for electricity.

Accelerate Depreciation of Utility Assets: Permits utilities to recover their plants' costs in a shorter period of time in comparison with the straight-line method.

Adoption of this procedure tends to raise rates (expenses) over the shortened depreciation schedule, with a corresponding decline later on. Accelerated depreciation techniques are recommended for specific nonmarketable

${ }^{271}$ In view of the relative importance of this subject, the Energy Information Administration (EIA) commissioned the Oak Ridge National Laboratory (ORNL) to undertake research on this topic. A part of this chapter is based on the recently completed report received by EIA from ORNL. Lester W. Baxter, the principal investigator, supported by Stan Hadley and Eric Hirst (from ORNL) participated in the research and in providing the results. For further details, see Oak Ridge National Laboratory, Strategies to Address Transition Costs in the Electricity Industry, ORNL/CON-431 (Oak Ridge, TN, July 1996).

${ }^{272}$ Another benefit of divestiture may be to foster the transfer of generation assets to corporate entities that may be able to operate them more eficiently than the current owner.

${ }^{273}$ Federal Energy Regulatory Commission, Electric Utility Depreciation Practices (Washington, DC, December 1980). 
assets, such as those under the category of regulatory assets. $^{274}$

Transfer Depreciation Reserves: Under this method, depreciation reserves from transmission and distribution categories are transferred to generation assets. Net plant valuation of generating assets is thereby reduced, with a corresponding increase in the net valuation of the above assets.

Accelerated Depreciation Offset with Decelerated Depreciation: This is the same as "accelerated depreciation" but with a countervailing proviso that decelerates depreciation charges in asset areas that are risk free (such as transmission and distribution assets). This procedure constrains (or offsets) increases in rates. ${ }^{275}$

Economic Levelization: When a plant or an asset is added to the rate base, a utility recovers depreciation together with income on its full value. The sum of these two is always higher in the initial years and declines continually over time (other things being equal) as the asset valuation is reduced by the amount depreciated each year. This regulatory approach tends to make the process "front-end loaded." Economic levelization keeps the depreciation expense of a resource constant (in real dollars) over time. Thus, economic levelization has the opposite effect of accelerated depreciation and may be viewed as a strategy during the transition to promote sales.

\section{Ratemaking Actions}

These strategies are linked with regulatory ratemaking and its linkage with recovery of embedded plant costs.

Adjust Utility Returns: Reducing a utility's authorized return will lower its revenues, earnings, and rates. For example, reducing the utility's authorized return from 10 percent to 8 percent for a given rate base will reduce earnings to shareholders by 20 percent, thus lowering the utility's revenue requirement and the rates the utility needs to charge to collect that revenue. However, if the utility is instead permitted to hold the rates constant (e.g., at 10 percent), then reducing a utility's authorized return (for reimbursement to shareholders) can be a transition-cost strategy. Shareholders earn the lower return (e.g., 8 percent) and the utility uses the balance (e.g., 2 percent), as embedded in current rates, to offset sunk obligations.

Eliminate Subsidies: This concept is based on the notion of utilities cross-subsidizing rates from one customer class to the other. Eliminating subsidies and/or discounts will enable "getting the prices right." Elimination of subsidies would permit customers to get a better indication of the utility's cost structure relative to alternative suppliers.

Restructure Rates: The suggested remedy is to design a two-part rate structure for all ratepayers, made up of energy rates approximating the utilities' marginal costs and a fixed charge covering their fixed costs. Such a rate structure reflects prices accurately and allows the utility to compete successfully during the time when it is a low-cost provider, thus avoiding uneconomic bypass of its generation system. It is claimed that this strategy can create a substantial value for the utilities by increasing the level of revenues during the transition to a fully competitive environment. ${ }^{276}$ Note that this is one way in which rates could be restructured. There are several other possibilities.

Unbundle Rates: In addition to the unbundling of rates suggested in the above strategy, rates could be further unbundled to include costs for transmission and distribution and ancillary services. It is claimed that charging unbundled rates for separate categories of services can lead to a reduction in stranded costs during transition.

Allow Rate Flexibility: The intent is to endow the utilities with flexibility in setting customer rates (prices) with the objective of reducing the level of stran$\mathrm{ded} /$ strandable costs.

\footnotetext{
${ }^{274}$ Regulatory assets include previously incurred costs that have been deferred for recovery in future rates with the concurrence of regulatory authorities. Such a classification is permissible under the provisions of Financial Accounting Standard (FAS) No. 71. Thus, regulatory assets include any costs that could or would have been otherwise expensed under standard accounting conventions. Examples of its components include regulatory tax assets recoverable through future rates, deferred finance charges, deferred environmental charges, unamortized property losses, unamortized demand-side management expenditures, certain post-retirement benefit costs, canceled or abandoned plants for which recovery of unamortized costs has been allowed, and others.

${ }^{275}$ As an example, the California Public Utility Commission (CPUC) granted a request from Southern California Edison (SCE) to accelerate the recovery of SCE's investment in the San Onofre nuclear power plant. In response to complaints that such an action would come at the expense of the existing ratepayers, the SCE modified its proposal to include deferred depreciation for transmission and distribution assets (which are likely to remain monopoly services).

${ }^{276}$ A. P. Della Valle and M. O. Bidwell, Jr., "Restructuring Rates Creates Value and Reduces Stranded Costs," Electricity Journal (December 1995), pp. 19-25.
} 
Performance-Based Ratemaking (PBR): Under this strategy, traditional cost-of-service ratemaking is replaced by either a price or revenue cap, which is adjusted periodically for inflation and a minimum productivity improvement target. This alternative provides the utilities with inducement to reduce costs and improve productivity and tends to shift risks from customers to the utility. To the extent that a portion of the savings can be used to offset potential strandable costs, PBR offers a viable solution.

Disallow Costs: Regulatory authorities could simply disallow certain costs from the rates. These disallowances could be related to above-market generating costs or other areas of utility operations deemed to be high relative to the industry. This strategy would be effective only in cases for costs not yet included in rates.

Explicitly Shift Costs to Captive Customers: The intent is to shift costs to captive customers rather than to departing customers. This is a rather unpopular strategy and is unlikely to be implemented because it mitigates stranded costs that might otherwise be allocated to noncaptive customers and/or to the utility's shareholders.

Exit Fees: Requires departing customers to pay exit fees based, for the most part, on the concept of embedded costs. Exit fees could be a lump sum payment or converted into a stream of payments. In dealing with the subject of stranded cost recovery, this strategy enjoys the support of FERC.

Net Generation Savings: This strategy aims to share the generation savings realized by the departing customers. Net generation savings, in this case, are defined as the difference between a utility's embedded cost of generation and the generation price obtained by the departing customer. Under this approach, a portion of the savings realized by the exiting customer is used to offset stranded costs. Proponents of this approach realize the difficulty in its implementation, since it may require the coordination of more than one regulatory authority.

Access Charge: An access charge could be levied for transmission and distribution services. This charge, which could be fixed or variable (i.e., depending on the level of usage), could be structured to include an element of stranded cost recovery either on the basis of a lump sum payment or as a regular payment stream. Difficulties may arise in its implementation due to interjurisdictional problems, since transmission rates need to be determined by FERC and distribution rates need to be handled by the States. The appeal of access charges lies in the fact that all customers contribute to the recovery of stranded costs.

\section{Utility Cost Reductions}

If savings resulting from utility cost reductions are to be applied to reduce or offset strandable costs, regulatory approval becomes necessary. Cost reductions may be viewed as efficiency gains provided they do not affect the quality or reliability of service to an unacceptable degree. Accordingly, cost reduction measures are welcome, since they do not involve shifting costs among different segments of the economy. Savings resulting from cost reductions could be shared between the ratepayers and the shareholders.

Reduce Operating Costs: Options available to achieve reductions in operating costs include reducing plant heat rates, trimming other operating and maintenance expenses, or retiring uneconomic plants.

Reduce Public Policy Program Costs: These include energy efficiency, low-income assistance, and research and development programs. Cutbacks in these programs could result in savings for a utility.

Reduce Power Purchase Costs: These costs can be reduced either by renegotiating contracts or by using thebuyout option where feasible. A number of investorowned utilities are using this option to lower their overall costs.

Financial Writedowns: A writedown is a charge against income implying that the extent of the writedown reflects a diminution in earnings for the shareholders. Under a writedown, the possibility of capital cost recovery in the future is eliminated. The strategy, however, permits a utility to take action on its own to become mure competitive (by paring historical costs of uneconomic plants).

\section{Tax Measures}

Options that include tax measures have an intuitive appeal, because taxes are deemed to be instruments of public policy. Promoters of tax-based options point out that the benefits of promoting competition in electricity trade will be enjoyed by the economy as a whole. Accordingly, the costs of transition should also be borne by the entire economy.

Consumption Tax: A consumption tax (similar to an excise or a sales tax) could be implemented either at the State or the Federal level. Revenues so received could be segregated in a trust fund for specific uses to include subsidizing the buyout of above-market power purchase 
contracts and other nonmarketable regulatory assets. Assuming the present value of strandable costs to be $\$ 100$ billion, a consumption tax of 0.5 cents per kilowatthour will be necessary for a 10 -year period. ${ }^{277}$ It is unlikely that such a tax will be seriously considered in the near future, because political support may not be secured for its implementation

National Tax for Nuclear Plants: This strategy is similar to the imposition of a Federal tax, except that it focuses on strandable costs associated with nuclear power plants. Federal taxation is recommended since Federal policies had a major role in the promotion of nuclear power.

Production Tax: This tax is similar to the consumption tax except for the difference that producers of power pay the tax instead of the customers. This makes the collection process simpler and perhaps less controversial.

Tax Reduction: A tax-reduction strategy can take many forms. This strategy was initially conceived as a reduction in the utility's marginal income tax rate at the State (where applicable) or Federal level. However, a tax reduction can so target a State's gross revenue tax collected by the utility. Because independent power producers do not collect this tax, a gross revenue tax acts to further differentiate utility prices from prices of alternative suppliers. In addition, some jurisdictions set higher property tax rates for utility-owned generators than for nonutility generators. These higher tax rates contribute to differences between costs (and prices) for utility-owned and nonutility generators. Setting a common property tax rate for all generators within the same jurisdiction (either by lowering the utility's property tax rate or raising the nonutility's rate) will reduce the difference in generation costs (and prices) between suppliers.

Tax Deduction: Under this strategy, a tax deduction or credit for uneconomic and unamortized investments in utility plants that utilities subsequently retire may be allowed. Such a deduction would have to be beyond (i.e., distinct from) the deduction from the loss against income that a utility takes as a result of writing down generating assets.

\section{Other Options}

These are strategies that cannot be conveniently categorized elsewhere. As usual, most of these strategies originated in suggestions for offsetting strandable costs.

Preserve Retail Franchise: Preservation of retail franchise is recommended as an option because delaying competition may permit utilities to lower the level of stranded costs. Except as another way of delaying or eliminating competition, it is difficult to see how this strategy addresses stranded or transition costs.

Eliminate Obligation To Serve: In the absence of obligation to serve, utilities may retire uneconomic assets or reduce excess capacity and thereby lower the level of potential strandable costs.

Statutorily Authorized Recovery: It is possible to enact legislation that would permit statutory recovery of stranded costs. Puget Power in Washington State, for example, has been assured of the recovery of its demandside management-related expenditures (its largest regulatory asset) in this manner. The legislation enacted in the State of Washington creates a new property right called the "bondable conservation investment," under which customer rates permit the recovery of demand-side management costs incurred by the utility. ${ }^{278}$

Entrance Fee for Returning Customers: Customers that depart the utility system and subsequently elect to return become liable to be charged an entry fee. The entrance fee could be structured to cover the transition costs incurred during the period the customer purchased power from alternative suppliers.

Entrance Fee for New Generation: New generation facilities coming on line after restructuring could be charged a fee to enter the market. Practical difficulties are likely to be encountered if this proposal is ever implemented. For example, who will collect this fee without abuse may be a problem. In addition, the procedure may introduce new unacceptable barriers to entry.

\footnotetext{
${ }^{277}$ Collecting the $\$ 100$ billion over a 10 -year period implies an annual payment of $\$ 15$ billion, assuming an 8-percent rate of interest. Demand for power is assumed to grow by 2 percent annually from its current levels (sales in 1994 were about 2.9 trillion kilowatthours). Thus, dividing $\$ 15$ billion by about 3.2 trillion kilowatthours yields about 0.5 cents per kilowatthour.

${ }^{278}$ State of Washington, Engrossed Senate Bill 5692, Conservation Investment by Public Utilities, approved on April 1, 1994. Puget Power had carried conservation investments (as regulatory assets) on its books with the regulatory promise of recovery through the rate base. No rate impact is envisaged, since the current customer rates permit for recovery of such investments. Passage of the legislation permits the utility to classify the regulatory asset as a statutory asset with resulting benefits in financing at a lower rate.
} 


\section{Who Bears Transition Costs?}

Most strategies identified above would shift costs among different segments of the economy (e.g., from shareholders to ratepayers, taxpayers, other independent power producers, or the State and Federal Government) either immediately or over a period of time.' As an example, shareholders of a utility with above-market generating costs will stand to suffer significant losses in the event that retail markets are opened rapidly, assuming that no other actions are taken either by the utility or the regulators. In contrast, utility cost reduction measures or implementation of efficiency improvements would lower potential stranded costs without any cost shifting.

Most mitigation strategies, however, involve a shifting or sharing of the costs by different economic segments (Table E2). These strategies are, however, broad based with the result that the sphere of operational accountability is enlarged to encompass all classes of participants, including utilities' shareholders, ratepayers, taxpayers, wheeling customers, and others. Whether one or more economic agent will bear the costs that a utility can no longer recover in a competitive environment (and are thus stranded) is determined by selection of a strategy for implementation.

Of the strategies discussed above, a qualitative assessment shows that ratepayers have the primary or secondary responsibility for absorbing the stranded costs in 19 strategies, shareholders in 12, wheeling customers in 11 , taxpayers in 8, and nonutility suppliers in 4 strategies (Table E2). Not all the strategies can be applied in a way to determine their impact (i.e., who pays stranded/ strandable costs) with neat precision.

As an example, depreciation reserves may be transferred among assets in an attempt to make generating assets less vulnerable (to competition) but only if bundled services continue to be provided. If rates are unbundled, costs would need to be shifted among the ratepayers and the wheeling customers. The tax consequences of the various strategies (such as revenue losses experienced by utilities or the writedown of assets) are not fully examined because of the inherent difficulties involved. A divestiture, in the absence of any countervailing action(s), will leave the onus on shareholders and the taxpayers in the event of a financial loss. It may also have significant impacts on local government finances.

\section{Quantitative Assessment of Different Strategies}

The Oak Ridge Financial Model (ORFIN) was used to assess the effects of selected mitigation strategies on the level of potential stranded costs. ${ }^{279}$ This model is a simplified version of a utility integrated planning model and includes a production-costing module, utility financial statements (income statement, balance sheet, and cash-flow statement), and a rate-design module (functionalization, classification, and allocation of costs to customer classes).

The estimation is based on the following three-step procedure:

- A base case utility is defined.

- A retail wheeling scenario (in which retail customers have the choice to select an alternative supplier) is created to estimate its consequences on the utility shareholders under assumptions of constant retail prices. ${ }^{280}$

- A mitigation strategy is incorporated to estimate its financial impact in comparison with the previous step. ${ }^{281}$

Table E3 summarizes the results of the different strategies and places them into large, medium, and modest impact categories. Their potential effects are compared with the base case utility's strandable costs. ${ }^{282}$ Since the absolute effects of different strategies are contingent on the assumptions made in creating the base case, Table E3

\footnotetext{
${ }^{279}$ The ORFIN is an integrated utility planning model developed at the Oak Ridge National Laboratory. Model characteristics are briefly described in Appendix D. For additional details with respect to the ORFIN model, refer to Oak Ridge National Laboratory, ORFIN: An Electric Financial and Production Simulator, ORNLCON-430 (Oak Ridge, TN, March 1996). The authors of the study (from which this summary has been adapted) prefer to use the term "transition costs," which is used synonymously with "stranded costs" or "strandable costs" in this report.

${ }^{280}$ The term "wheeling" implies moving electric power from one system to another over the transmission facilities of the intervening systems. Within the context of industry restructuring, wholesale or retail buyers of electricity have the freedom to select a supplier of their choice. Wholesale wheeling indicates bulk transactions in the wholesale market, whereas retail wheeling allows producers direct access to retail customers.

${ }^{281}$ Estimating the impact of some strategies by keeping the retail prices constant is not always feasible. Strategies that involve a reduction in public policy programs may be permissible only in conjunction with a change in rates. In such a case, the approach used is to define a revised base case that include changes to the utility's cost structure as a result of the strategy adopted and then to estimate its impact on strandable costs.

${ }^{282}$ It is emphasized that the results presented are with reference to the specifics of the base case utility only. Any attempt to generalize these conclusions would, therefore, be inappropriate.
} 


\begin{tabular}{|c|c|c|c|c|c|}
\hline Strategy & $\begin{array}{c}\text { Utility } \\
\text { Shareholders }\end{array}$ & Ratepayers & Taxpayers & $\begin{array}{l}\text { Wheeling } \\
\text { Customers }\end{array}$ & QFs, IPPs \\
\hline \multicolumn{6}{|l|}{ Market Actions } \\
\hline Open markets . & $\mathbf{P}$ & -- & $\mathbf{s}$ & .. & s \\
\hline Delay competition ... & -- & $\mathbf{P}$ & -- & -- & -. \\
\hline Divest utility plant $\ldots \ldots \ldots$ & $P$ & -- & $\mathbf{s}$ & -- & -- \\
\hline Mergers $^{a} \ldots \ldots \ldots \ldots \ldots \ldots \ldots \ldots$ & -- & .- & -- & -- & -- \\
\hline Market excess power ............... & $P$ & $P$ & -- & -- & - \\
\hline \multicolumn{6}{|l|}{ Depreciation Options } \\
\hline Accelerate depreciation & -- & $\mathbf{P}$ & -- & .- & -- \\
\hline Accelerate/decelerate depreciation & -- & $\mathbf{P}$ & -- & -. & .- \\
\hline Transfer depreciation reserves..$\ldots \ldots \ldots$ & -- & $P$ & -- & $\mathbf{s}$ & .- \\
\hline Economic levelization . .............. & -- & $\mathbf{P}$ & -- & - & -- \\
\hline \multicolumn{6}{|l|}{ Ratemaking Actions } \\
\hline Adjust utility returns & $\mathbf{P}$ & & $\mathbf{s}$ & -- & -- \\
\hline Eliminate subsidies $\ldots \ldots \ldots \ldots \ldots \ldots \ldots$ & -- & $\mathbf{P}$ & -. & -. & -- \\
\hline Restructure rates $\ldots \ldots \ldots \ldots \ldots \ldots \ldots$ & -- & $\mathrm{P}$ & -- & -- & -- \\
\hline Unbundle rates $\ldots \ldots \ldots \ldots \ldots \ldots \ldots$. & .- & $\mathrm{P}$ & -- & $\mathbf{s}$ & .- \\
\hline Allow rate flexibility .... & -- & $\mathbf{P}$ & -- & -- & -- \\
\hline Performance-based rates $\ldots \ldots \ldots$ & $\mathbf{P}$ & $\mathbf{s}$ & & -- & -- \\
\hline Disallow costs $\ldots \ldots \ldots \ldots \ldots \ldots \ldots$ & $\mathbf{P}$ & -- & $\mathbf{s}$ & $\ldots$ & -- \\
\hline Explicitly shift costs to captive customers & -. & $\mathrm{P}$ & -- & -- & .. \\
\hline Exit fees $\ldots \ldots \ldots \ldots \ldots \ldots \ldots \ldots$ & -- & -- & - & $\mathbf{P}$ & -- \\
\hline Net generation savings $\ldots \ldots \ldots \ldots \ldots \ldots$ & $P$ & -- & -- & $\mathrm{P}$ & -- \\
\hline Access charges ........... & -- & $P$ & - & $P$ & -- \\
\hline \multicolumn{6}{|l|}{ Utility Cost Reductions } \\
\hline Reduce operating costs & $\mathbf{P}$ & $\mathbf{P}$ & -. & -- & .. \\
\hline Reduce public policy program costs ${ }^{b}$. & -- & -- & -- & -- & -- \\
\hline Reduce power purchase costs. & $P$ & - & -- & -- & $\mathbf{P}$ \\
\hline Financial writedowns ............... & $P$ & -- & s & -- & -- \\
\hline \multicolumn{6}{|l|}{ Tax Measures } \\
\hline Consumption tax & .- & $\mathrm{P}$ & -- & $\mathbf{P}$ & .- \\
\hline National tax for nuclear plants & -- & $\mathbf{P}$ & -- & $\mathrm{P}$ & -- \\
\hline Production $\operatorname{tax} \ldots \ldots \ldots \ldots \ldots$ & $\mathbf{s}$ & $\mathbf{P}$ & -- & $\mathbf{P}$ & $\mathbf{s}$ \\
\hline Tax reduction $\ldots \ldots \ldots \ldots \ldots \ldots \ldots$ & -. & -- & $\mathbf{P}$ & -. & -. \\
\hline Tax deduction $\ldots \ldots \ldots \ldots \ldots \ldots \ldots$ & -- & -- & $P$ & -- & - \\
\hline \multicolumn{6}{|l|}{ Other Options } \\
\hline Preserve retail franchise ..... & .. & $\mathbf{P}$ & -- & -- & -- \\
\hline Eliminate obligation to serve ..... & $\mathbf{P}$ & -- & S & -- & -- \\
\hline Statutorily authorized recovery ......... & -- & $\mathrm{P}$ & -- & $\mathbf{P}$ & - \\
\hline Entrance fee for returning customers .... & -- & -- & -- & $\mathbf{P}$ & - \\
\hline Entrance fee for new generation $\ldots \ldots \ldots$ & -. & -- & -- & $s$ & $\mathbf{P}$ \\
\hline
\end{tabular}

${ }^{\mathrm{a}}$ Assessing the effects mergers will have on transition costs is beyond the concept of the ORFIN model.

${ }^{b}$ Reductions in public policy program costs reflect reductions in services. Prospective program participants and society in general will bear the transition costs.

IPP = Independent power producer.

$P=$ Actor with primary responsibility.

QF = Qualifying facility.

$S=$ Actor with secondary responsibility.

$-=$ Not applicable.

Source: Oak Ridge National Laboratory, Strategies to Address Transition Costs in the Electricity Industry, ORNLCON-431 (Oak Ridge, TN, July 1996). 
Table E3. Potential Effects of Different Strategies on Base-Case Utility Transition Costs

\begin{tabular}{|c|c|c|c|}
\hline \multirow{2}{*}{$\begin{array}{l}\text { Potential Effect on } \\
\text { Utility Transition Costs }\end{array}$} & \multirow[b]{2}{*}{ Strategy ${ }^{a}$} & \multicolumn{2}{|c|}{$\begin{array}{l}\text { Financial Impacts } \\
\text { (Million Dollars) }\end{array}$} \\
\hline & & Increase & Decrease \\
\hline Large (25 percent or greater) ... & $\begin{array}{l}\text { Rapidly open retail markets }(+) \\
\text { Delay retail wheeling }(-) \\
\text { Market excess energy }( \pm) \\
\text { Charge exit fees }(-) \\
\text { Reduce administrative and general costs }(-) \\
\text { Discount qualifying facility energy payments } \\
\text { to market }(-)\end{array}$ & $\begin{array}{l}2,361(+96.0) \\
662(+27.0)\end{array}$ & $\begin{array}{l}-788(-32.2) \\
-111(-4.5) \\
-2,363(-96.5) \\
-1,049(-42.8) \\
-2,481(-101.3)\end{array}$ \\
\hline $\begin{array}{l}\text { Medium (between } \mathbf{5} \text { and } \mathbf{2 5} \\
\text { percent) } \ldots \ldots \ldots \ldots \ldots \ldots\end{array}$ & $\begin{array}{l}\text { Increase system load factors ( } \pm \text { ) } \\
\text { Accelerate depreciation of the generation } \\
\text { plant (+) } \\
\text { Charge wheeling customers for ancillary } \\
\text { services (-) } \\
\text { Reduce customer-service costs (-) } \\
\text { Reduce transmission operating and } \\
\text { maintenance costs (-) } \\
\text { Reduce distribution operating and } \\
\text { maintenance costs (-) } \\
\text { Reduce generation operating and } \\
\text { maintenance costs (-) } \\
\text { Discount qualifying facility capacity payments } \\
\text { to market (-) }\end{array}$ & $\begin{array}{l}208(+8.5) \\
119(+4.9)\end{array}$ & $\begin{array}{l}-165(-6.7) \\
-240(-9.8) \\
-381(-15.6) \\
-194(-7.9) \\
-246(-10.0) \\
-467(-19.1) \\
-410(-16.7)\end{array}$ \\
\hline Modest (less than 5 percent) ... & $\begin{array}{l}\text { Accelerate depreciation of the generation } \\
\text { plant and decelerate depreciation of the } \\
\text { transmission and distribution plant }(+) \\
\text { Accelerate depreciation of regulatory assets } \\
( \pm) \\
\text { Reduce public policy program costs }(-)\end{array}$ & $\begin{array}{l}49(+2.0) \\
77(+3.1)\end{array}$ & $\begin{array}{l}-38(-1.6) \\
-23(-1.0)\end{array}$ \\
\hline
\end{tabular}

${ }^{a} A$ " $(+)$ " indicates the strategy increases transition costs; a "(-)" indicates the strategy decreases transition costs; a "( $( \pm)$ " indicates the strategy may increase or decrease transition costs.

Note: The numbers in parentheses reflect increases or decreases as a percentage of the total stranded costs of the hypothetical utility.

Source: Oak Ridge National Laboratory, Strategies to Address Transition Costs in the Electricity Industry, ORNL/CON-431 (Oak Ridge, TN, July 1996). 
provides a general indication of how the strategy might work in similar applications comparable to the base case. However, not all utilities may have the potential for stranded costs, and the potentially affected utilities will have above-market costs in at least one of three areas: utility-owned generation, power purchase contracts, and regulatory assets.

Several of the mitigation strategies can potentially reduce the magnitude of a utility's strandable costs. However, a number of strategies require regulatory approval for implementation, particularly, exit fees and depreciation options.

Utility cost reduction strategies have a significant appeal because most of them can be initiated by the utilities themselves with positive results in lowering strandable costs. A number of utilities have already embarked on such programs with encouraging results. The danger in this situation results from going too far, so that essential maintenance activities may be stretched out with unacceptable consequences. In the midst of changes that are now occurring in the electric utility industry, maintaining the reliability of the Nation's bulk electric systems poses new challenges. ${ }^{283}$

A resolution of who pays stranded costs will have a major impact upon, but will not be the sole issue that determines, the speed at which transition of the industry to a competitive mode is accomplished. While FERC Order 888 clearly places the onus of stranded cost recovery on the backs of departing customers, there are no clear signals with respect to recovery of similar costs in the area of retail trade, due to the lack of a uniform approach among State regulatory authorities. Many States are still grappling with this issue.

The results presented above must be interpreted with caution. Utility cost structures differ in critical areas that render interutility comparisons without further investigation inappropriate. Generally, these differences account for whether a utility is a high-cost or a low-cost producer. Thus, the results of a strategy application are difficult to generalize, but they may indicate that a case-by-case investigation would be useful in determining the efficacy of the strategy.

A more detailed explanation of the three-step estimation procedure follows.

\section{Base Case}

The construct of a hypothetical base case utility is based on selecting a utility that potentially faces substantial transition (or strandable) costs. Data for the 1994-1995 period are used. The intent is not to simulate any particular utility's performance nor that of the whole industry, but rather to make the assessments consistent with actual data.

Following are the characteristics of the base case utility:
Rate base:
$\$ 7.3$ billion
Common equity:
$\$ 3.2$ billion
Revenues:
$\$ 4.6$ billion
Annual retail sales:
Total generating capacity:
Utility-owned capacity:
Long-term purchase contracts:
Retail peak demand:
43,800 gigawatthours
10,000 megawatts
5,200 megawatts
4,800 megawatts
7,500 megawatts

Long-term power purchase contracts are in effect through the 10-year analysis period. The utility's total capacity of 10,000 megawatts consists of 13 percent nuclear, 16 percent coal, 8 percent natural gas, 7 percent hydroelectric, 8 percent oil, 17 percent hydroelectric purchases, and 31 percent purchases from QFs. Note that nearly 90 percent of the $Q F$ contracts (about 2,800 megawatts) have "must run" provisions, which imply that the utility must purchase the power when it is available. The combined capacity and energy payments for these must-run contracts are about 7.2 cents per kilowatthour.

The utility's large coal plant (1,570 megawatts), one of its natural gas plants, and all of its hydroelectric plants are fully depreciated. Its nuclear plant will be fully depreciated in 2018. The utility's regulatory assets are about $\$ 1.0$ billion. The utility's annual sales and peak demand grow by about 1.0 percent each year (assuming the absence of retail wheeling). Its system load factor is 66 percent.

The utility is active in the wholesale market given its surplus capacity, transmission links, and low marginal generation costs of about 2.1 cents per kilowatthour. Its wholesale sales, which are about 9,400 gigawatthours, are projected to decline by about 4 percent annually into the future. Its purchases of about 1,000 gigawatthours are projected to increase by about 9 percent annually. The

${ }^{283}$ U. S. Department of Energy, The Electric Power Outages in the Western United States, July 2-3, 1996: Report to the President (Washington, DC, August 1996). 
utility is assumed to be a "price-taker" in the market-i.e., its purchases or sales have no effect on market prices.

In estimating rates for each customer class for the base case, the utility's revenue requirements include all its costs and an authorized rate of return of 11 percent on its equity. The hypothetical utility's customer rates are well above the national average.

With inflation assumed to average 3 percent annually, the real discount rate works out to be 8 percent. With assumptions of no real increases in fuel prices and no new generating units (but new investments in transmission and distribution facilities), the base case utility's projections (for selected variables and with no retail wheeling) for the period 1995 through 2005 are shown in Table E4.

\section{Retail Wheeling Case}

The retail wheeling case assumes that wheeling starts in 1996 for commercial and industrial customers, with the result that 60 percent of them have alternative suppliers by 1998 . Residential customers commence wheeling in 1997 , and 40 percent of them secure supplies from alternative sources by 2000 . These percentages are kept constant, and the impact of the changes on the base case utility is evaluated.
The results of the hypothesized wheeling experiment show a decline in utility retail sales by 24,700 gigawatthours (or by about 54 percent) by the year 2000 (Table E5). Wholesale purchases by the utility are eliminated and are replaced by a significant increase in wholesale sales. The utility's per-unit production costs increase since costs are spread over a declining customer base. Net income losses amount to $\$ 137$ million in 1996, peaking at \$527 million in 2000 before declining graduallyto $\$ 510$ million by 2005 . The net present value of aggregate losses, or the transition cost, is $\$ 2.45$ billion, representing about 77 percent of the firm's 1995 equity of $\$ 3.2$ billion.

\section{Assessing Impacts of Selected Mitigation Strategies}

To eliminate the need to make arbitrary assumptions about the utility's cost variables, performance benchmarks were established for designated areas of operation. These include administrative and general expenses, customer services, transmission and distribution, and operations and management expenses. In addition, benchmarks for fixed and variable costs of various generating plants (by fuel type) were also established by using a statistical technique (Table E6). ${ }^{284}$

${ }^{284}$ In establishing benchmarks for various cost categories, all medium to large-sized electric utilities were selected from a database that contains all U.S. electric utilities. Using the subset so derived, the frequency distribution of each cost variable was examined. Its mean, median, standard deviation and resulting frequency distribution were then estimated. For each cost distribution, its 90 th percentile value was estimated after accounting for various other factors that might bias the selection process. For additional details, refer to Oak Ridge National Laboratory, Strategies to Address Transition Costs in the Electricity Industry, ORNL/CON-431 (Oak Ridge, TN, July 1996). 
Table E4. Base Case Utillty Projections (No Wheeling)

\begin{tabular}{|c|c|c|c|c|c|c|c|}
\hline & 1995 & 1996 & 1997 & 1998 & 1999 & 2000 & 2005 \\
\hline Retail Sales (GWh) at Busbar . . . . . . . & 43,809 & 44,274 & 44,744 & 45,220 & 45,700 & 46,187 & 48,700 \\
\hline Wholesale (spot) Purchases (GWh) .. & $-1,020$ & $-1,129$ & $-1,242$ & $-1,364$ & $-1,494$ & $-1,634$ & $-2,471$ \\
\hline Net Wholesale GWh . .......... & 8,404 & 7,940 & 7,471 & 6,997 & 6,517 & 6,033 & 3,521 \\
\hline Retail $\ldots \ldots \ldots \ldots \ldots \ldots \ldots \ldots$ & 7,522 & 7,603 & 7,685 & 7,768 & 7,852 & 7,937 & 8,376 \\
\hline Wholesale Sales ............. & 1,941 & 1,897 & 1,853 & 1,810 & 1,766 & 1,722 & 1,493 \\
\hline Wholesale Purchases . . . . . . . . . & 680 & 707 & 721 & 742 & 770 & 801 & 906 \\
\hline Retail Wheeling . . . . . . . . . . & 0 & 0 & 0 & 0 & 0 & 0 & 0 \\
\hline Fixed $\ldots \ldots \ldots \ldots \ldots \ldots \ldots$ & 2.82 & 2.64 & 2.46 & 2.30 & 2.14 & 2.00 & 1.44 \\
\hline Variable $\ldots \ldots \ldots \ldots \ldots \ldots \ldots$ & 2.82 & 2.81 & 2.81 & 2.80 & 2.80 & 2.79 & 2.76 \\
\hline Total $\ldots \ldots \ldots \ldots \ldots \ldots \ldots$ & 5.64 & 5.45 & 5.27 & 5.10 & 4.94 & 4.79 & 4.20 \\
\hline Return on Equity (Percent) ......... & 11.00 & 11.00 & 11.00 & 11.00 & 11.00 & 11.00 & 11.00 \\
\hline \multicolumn{8}{|l|}{$\begin{array}{l}\text { Income Statement (million nominal } \\
\text { dollars) }\end{array}$} \\
\hline Revenues.... & 4,615 & 4,705 & 4,799 & 4,898 & 5,001 & 5,110 & 5,767 \\
\hline \multicolumn{8}{|l|}{ Expenses } \\
\hline Fuel $\ldots \ldots \ldots \ldots \ldots \ldots \ldots$ & 287 & 295 & 304 & 313 & 323 & 332 & 385 \\
\hline Purchase-Power Constraints ..... & 1,405 & 1,438 & 1,473 & 1,508 & 1,545 & 1,583 & 1,789 \\
\hline Book Depreciation . . . . . . . . . . . & 231 & 235 & 240 & 245 & 251 & 256 & 283 \\
\hline Depreciation of Regulatory Asset ..... & 91 & 91 & 91 & 91 & 91 & 91 & 91 \\
\hline Revenue Sensitive Taxes ......... & 462 & 470 & 480 & 490 & 500 & 511 & 577 \\
\hline Property Taxes ............... & 317 & 319 & 322 & 325 & 328 & 331 & 350 \\
\hline Federal Income Taxes - Current ..... & 201 & 197 & 193 & 189 & 186 & 185 & 265 \\
\hline Federal Income Taxes - Deferred .... & 35 & 35 & 35 & 35 & 35 & 33 & -49 \\
\hline Expenses - Total . . . . . . . . . . . . & 3,977 & 4,074 & 4,176 & 4,281 & 4,392 & 4,507 & 5,169 \\
\hline Interest Expense $\ldots \ldots$ & 284 & 282 & 281 & 280 & 278 & 277 & 275 \\
\hline Net Income $\ldots \ldots \ldots \ldots \ldots \ldots \ldots$ & 355 & 349 & 343 & 337 & 331 & 326 & 323 \\
\hline \multicolumn{8}{|l|}{ BALANCE SHEET } \\
\hline Assets $\ldots \ldots \ldots \ldots \ldots \ldots \ldots$ & 7,269 & 7,229 & 7,192 & 7,160 & 7,132 & 7,107 & 7,053 \\
\hline Equity $\ldots \ldots \ldots \ldots \ldots \ldots \ldots$ & 3,196 & 3,141 & 3,088 & 3,036 & 2,987 & 2,942 & 2,963 \\
\hline
\end{tabular}

Source: Oak Ridge National Laboratory, Strategies to Address Transition Costs in the Electricity Industry, ORNLCON-431 (Oak Ridge, TN, July 1996). 
Table E5. Base Case Utility Projections (With Wheeling)

\begin{tabular}{|c|c|c|c|c|c|c|c|}
\hline & 1995 & 1996 & 1997 & 1998 & 1999 & 2000 & 2005 \\
\hline \multicolumn{8}{|l|}{ Annual Summary } \\
\hline Retail Sales (GWh) at Busbar ..... & 0 & $-6,036$ & $-13,611$ & $-21,335$ & $-23,012$ & $-24,732$ & $-26,024$ \\
\hline Wholesale (spot) Sales (GWh) .... & 0 & 5,080 & 12,265 & 18,965 & 20,341 & 21,505 & 22,372 \\
\hline Wholesale (spot) Purchases (GWh) & 0 & 898 & 1,237 & 1,364 & 1,494 & 1,634 & 2,471 \\
\hline Net Wholesale GWh ........... & 0 & 5,978 & 13,502 & 20,329 & 21,835 & 23,139 & 24,843 \\
\hline Retail Wheeling $\ldots \ldots \ldots \ldots \ldots$ & 0 & 6,036 & 13,611 & 21,335 & 23,012 & 24,732 & 26,024 \\
\hline \multicolumn{8}{|l|}{ Peak Demand at Busbar (MW) } \\
\hline ............ & 0 & -984 & $-2,258$ & $-3,558$ & $-3,873$ & $-4,195$ & $-4,418$ \\
\hline Wholesale Sales ............. & 0 & 578 & 1,249 & 1,701 & 1,821 & 1,907 & 2,094 \\
\hline Wholesale Purchasing $\ldots \ldots \ldots \ldots$ & 0 & -468 & -711 & -742 & -770 & -801 & -906 \\
\hline Retail Wheeling..$\ldots \ldots \ldots$ & 0 & 984 & 2,258 & 3,558 & 3,873 & 4,195 & 4,418 \\
\hline \multicolumn{8}{|l|}{ Costs and Prices (1994 $d / \mathrm{kWh})$} \\
\hline Average Retail Price $\ldots \ldots \ldots \ldots$ & 0 & 0.19 & 0.34 & 0.60 & 0.48 & 0.34 & 0.32 \\
\hline \multicolumn{8}{|l|}{ Average Production Costs } \\
\hline Fixed & 0 & 0.42 & 1.08 & 2.05 & 2.17 & 2.30 & 1.65 \\
\hline Variable $\ldots \ldots \ldots \ldots \ldots \ldots$ & 0 & 0.07 & 0.20 & 0.43 & 0.48 & 0.56 & 0.52 \\
\hline Total $\ldots \ldots \ldots \ldots \ldots \ldots \ldots$ & 0 & 0.49 & 1.27 & 2.48 & 2.66 & 2.86 & 2.17 \\
\hline Return on Equity (Percent) ........ & 0 & -4.33 & -9.22 & -14.72 & -16.20 & -17.79 & -17.37 \\
\hline \multicolumn{8}{|l|}{$\begin{array}{l}\text { Income Statement (million nominal } \\
\text { dollars) }\end{array}$} \\
\hline Revenues ................. & 0 & -422 & -921 & $-1,453$ & $-1,591$ & $-1,734$ & $-1,870$ \\
\hline \multicolumn{8}{|l|}{ Expenses } \\
\hline$\ldots \ldots \ldots \ldots \ldots \ldots$ & 0 & 0 & 0 & -9 & -13 & -19 & -15 \\
\hline Purchase-Power Constraints .... & 0 & -4 & -7 & -8 & -8 & -8 & -10 \\
\hline Spot Purchases ............. & 0 & -31 & -45 & -50 & -56 & -62 & -102 \\
\hline Spot Sales . ............... & 0 & -116 & -299 & -489 & -540 & -590 & -704 \\
\hline Purchases Power - Total ......... & 0 & -151 & -350 & -546 & -604 & -660 & -815 \\
\hline O\&M, Fixed + Variable $\ldots \ldots \ldots \ldots$ & 0 & 0 & 0 & -1 & -2 & -2 & -2 \\
\hline Production Expenses - Total ...... & 0 & -151 & -350 & -557 & -618 & -681 & -832 \\
\hline Nonproduction Expenses ......... & 0 & 0 & 0 & 0 & 0 & 0 & 0 \\
\hline Book Depreciation ............. & 0 & 0 & 0 & 0 & 0 & 0 & 0 \\
\hline Depreciation of Regulatory Asset ... & 0 & 0 & 0 & 0 & 0 & 0 & 0 \\
\hline Revenue Sensitive Taxes . . . . . . . & 0 & -42 & -92 & -145 & -159 & -173 & -187 \\
\hline Property Taxes & 0 & 0 & 0 & 0 & 0 & 0 & 0 \\
\hline Federal Income Taxes - Current ... & 0 & -92 & -191 & -300 & -325 & -352 & -340 \\
\hline Federal Income Taxes - Deferred .. & 0 & 0 & 0 & 0 & 0 & 0 & 0 \\
\hline Expenses - Total . . . . . . . . . . & 0 & -284 & -634 & $-1,003$ & $-1,103$ & $-1,206$ & $-1,359$ \\
\hline Interest Expense & 0 & 0 & 0 & 0 & 0 & 0 & 0 \\
\hline Net Income $\ldots . .$. & 0 & -137 & -287 & -451 & -488 & -527 & -510 \\
\hline \multicolumn{8}{|l|}{ BALANCE SHEET } \\
\hline Assets & 0 & 0 & 0 & 0 & 0 & 0 & 0 \\
\hline Equity . & 0 & 0 & 0 & 0 & 0 & 0 & 0 \\
\hline
\end{tabular}

Note: The numbers in each column are derived by subtracting the "Base Case Utility Projections" from projections of the base case with assumptions regarding wheeling.

Source: Oak Ridge National Laboratory, Strategies to Address Transition Costs in the Electricity Industry, ORNLCON-431 (Oak Ridge, TN, July 1996). 


\begin{tabular}{|c|c|c|c|}
\hline Cost Variable & Base Case Value & Industry Average & $\begin{array}{c}\text { Performance } \\
\text { Benchmark }\end{array}$ \\
\hline Administrative \& General (dollars/customer) & 231 & 156 & 96 \\
\hline Customer Service (dollars/customer) & 92 & 63 & 45 \\
\hline \multicolumn{4}{|l|}{ Administrative \& General, Customer Service } \\
\hline Combined (dollars/customer) & 323 & 219 & 154 \\
\hline Transmission Operations and Maintenance (dollars/kW-yr) & 8 & 4 & 2 \\
\hline Distribution Operations and Maintenance (dollars $/ \mathrm{kW}-\mathrm{yr}$ ) & 20 & 12 & 8 \\
\hline \multicolumn{4}{|l|}{ Plant Operations and Maintenance } \\
\hline \multicolumn{4}{|l|}{ Nuclear } \\
\hline Fixed (dollars/kW-yr) & 125 & 91 & 61 \\
\hline Variable (cents $/ \mathrm{kWh}) \ldots \ldots \ldots \ldots$ & 0.06 & 0.04 & 0.03 \\
\hline \multicolumn{4}{|l|}{ Coal } \\
\hline Fixed (dollars/kW-yr) & 23 & 26 & 12 \\
\hline Variable (cents/kWh) & 0.16 & 0.18 & 0.08 \\
\hline \multicolumn{4}{|l|}{ Natural Gas 1} \\
\hline Fixed (dollars/kW-yr) & 22 & 24 & 8 \\
\hline Variable (cents $/ \mathrm{kWh}) \ldots \ldots \ldots \ldots \ldots$ & 0.09 & 0.10 & 0.03 \\
\hline \multicolumn{4}{|l|}{ Oil } \\
\hline Fixed $($ dollars $/ k w-y r) \ldots \ldots \ldots \ldots \ldots \ldots \ldots \ldots$ & 6 & 7 & 2 \\
\hline Variable $($ cents $/ k W h) \ldots \ldots \ldots \ldots \ldots \ldots \ldots \ldots \ldots$ & 0.11 & 0.13 & 0.03 \\
\hline \multicolumn{4}{|l|}{ Hydro } \\
\hline Fixed (dollars/kW-yr) & 4 & 12 & 3 \\
\hline Variable (cents/kWh) & 0.08 & 0.24 & 0.06 \\
\hline
\end{tabular}

$\mathrm{kW}=$ Kilowatt.

$k W h=$ Kilowatthour

Source: Oak Ridge National Laboratory, Strategies to Address Transition Costs in the Electricity Industry, ORNLCON-431 (Oak Ridge, TN, July 1996). 

Appendix F

Selected Provisions of the Energy Policy Act of 1992

(Public Law 102-486),

Title VII-Electricity 


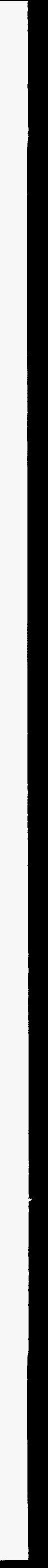




\title{
Selected Provisions of the Energy Policy Act of 1992 (Public Law 102-486), Title VII-Electricity
}

\author{
Subtitle A-Exempt Wholesale Generators
}

15 USC 79, $79 z-6$.

15 USC 79z-5a.

Regulations

\section{SEC. 711. PUBLIC UTILITY HOLDING COMPANY ACT REFORM.}

The Public Utility Holding Company Act of 1935 (15 U.S.C. 79 and following) is amended by redesignating sections 32 and 33 as sections 34 and 35 respectively and by adding the following new section after section 31 :

"SEC. 32. EXEMPT WHOLESALE GENERATORS.

“(a) DEFINITIONS.-For purposes of this section-

“(1) EXEMPT WHOLESALE GENERATOR.-The term 'exempt wholesale generator' means any person determined by the Federal Energy Regulatory Commission to be engaged directly, or indirectly through one or more affiliates as defined in section 2(a)(11)(b), and exclusively in the business of owning or operating, or both owning and operating, all or part of one or more eligible facilities and selling electric energy at wholesale. No person shall be deemed to be an exempt wholesale generator under this section unless such person has applied to the Federal Energy Regulatory Commission for a determination under this paragraph. A person applying in good faith for such a determination shall be deemed an exempt wholesale generator under this section, with all of the exemptions provided by this section, until the Federal Energy Regulatory Commission makes such determination. The Federal Energy Regulatory Commission shali make such determination within 60 days of its receipt of such application and shall notify the Commission whenever a determination is made under this paragraph that any person is an exempt wholesale generator. Not later than 12 months after the date of enactment of this section, the Federal Energy Regulatory Commission shall promulgate rules implementing the provisions of this paragraph. Applications for determination filed after the effective date of such rules shall be subject thereto.

"(2) ELIGIBLE FACILITY.-The term 'eligible facility' means a facility, wherever located, which is either-

"(A) used for the generation of electric energy exclusively for sale at wholesale, or

"(B) used for the generation of electric energy and leased to one or more public utility companies; Provided, That any such lease shall be treated as a sale of electric energy at wholesale for purposes of sections 205 and 206 of the Federal Power Act.

Such term shall not include any facility for which consent is required under subsection (c) if such consent has not been obtained. Such term includes interconnecting transmission facilities necessary to effect a sale of electric energy at wholesale. For purposes of this paragraph the term 'facility' may include a portion of a facility subject to the limitations of subsection (d) and shall include a facility the construction of which has not been commenced or completed.

“(3) SALE OF ELECTRIC ENERGY AT WHOLESALE.-The term 'sale of electric energy at wholesale' shall have the same meaning as provided in section 201(d) of the Federal Power Act (16 U.S.C. 824(d)). 
“(4) RETAIL RATES AND CHARGES.-The term 'retail rates and charges' means rates and charges for the sale of electric energy directly to consumers.

“(b) FOREIGN RETAIL SALES.-Notwithstanding paragraphs (1) and (2) of subsection (a), retail sales of electric energy produced by a facility located in a foreign country shall not prevent such facility from being an eligible facility, or prevent a person owning or operating, or both owning and operating, such facility from being an exempt wholesale generator if none of the electric energy generated by such facility is sold to consumers in the United States.

“(c) STATE CONSENT FOR EXISTING RATE-BASED FACILITIES.- If a rate or charge for, or in connection with, the construction of a facility, or for electric energy produced by a facility (other than any portion of a rate or charge which represents recovery of the cost of a wholesale rate or charge) was in effect under the laws of any State as of the date of enactment of this section, in order for the facility to be considered an eligible facility, every State commission having jurisdiction over any such rate or charge must make a specific determination that allowing such facility to be an eligible facility (1) will benefit consumers, (2) is in the public interest, and (3) does not violate State law; Provided, That in the case of such a rate or charge which is a rate or charge of an affiliate of a registered holding company:

"(A) such determination with respect to the facility in question shall be required from every State commission having jurisdiction over the retail rates and charges of the affiliates of such registered holding company; and

“(B) the approval of the Commission under this Act shall not be required for the transfer of the facility to an exempt wholesale generator.

"(d) HYBRIDS.-(1) No exempt wholesale generator may own or operate a portion of any facility if any other portion of the facility is owned or operated by an electric utility company that is an affiliate or associate company of such exempt wholesale generator.

“(2) ELIGIBLE FACILITY.-Notwithstanding paragraph (1), an exempt wholesale generator may own or operate a portion of a facility identified in paragraph (1) if such portion has become an eligible facility as a result of the operation of subsection (c).

“(e) EXEMPTION OF EWGS.-An exempt wholesale generator shall not be considered an electric utility company under section 2(a)(3) of this Act and, whether or not a subsidiary company, an affiliate, or an associate company of a holding company, an exempt wholesale generator shall be exempt from all provisions of this Act.

"(f) OWNERSHIP OF EWGS BY EXEMPT HOLDING COMPANIES.- Notwithstanding any provision of this Act, a holding company that is exempt under section 3 of this Act shall be permitted, without condition or limitation under this Act, to acquire and maintain an interest in the business of one or more exempt wholesale generators.

“(g) OWNERSHIP OF EWGS BY REGISTERED HOLDING COMPANIES.- Notwithstanding any provision of this Act and the Commission's jurisdiction as provided under subsection (h) of this section, a registered holding company shall be permitted (without the need to apply for, or receive, approval from the Commission, and otherwise without condition under this Act) to acquire and hold the securities, or an interest in the business, of one or more exempt wholesale generators.

“(h) FINANCING AND OTHER RELATIONSHIPS BETWEEN EWGS AND REGISTERED HOLDING COMPANIES.-The issuance of securities by a registered holding company for purposes of financing the acquisition of an exempt wholesale generator, the guarantee of securities of an exempt wholesale generator by a registered holding company, the entering into service, sales or construction contracts, and the creation or maintenance of any other relationship in addition to that described in subsection (g) between an exempt wholesale generator and a registered holding company, its affiliates and associate companies, shall remain subject to the jurisdiction of the Commission under this Act: Provided, That-

"(1) section 11 of this Act shall not prohibit the ownership of an interest in the business of one or more exempt wholesale generators by a registered holding company (regardless of where facilities owned or operated by such exempt wholesale generators are located), and such ownership by a registered holding company shall be deemed consistent with the operation of an integrated public utility system; 
"(2) the ownership of an interest in the business of one or more exempt wholesale generators by a registered holding company (regardless of where facilities owned or operated by such exempt wholesale generators are located) shall be considered as reasonably incidental, or economically necessary or appropriate, to the operations of an integrated public utility system;

"(3) in determining whether to approve (A) the issue or sale of a security by a registered holding company for purposes of financing the acquisition of an exempt wholesale generator, or (B) the guarantee of a security of an exempt wholesale generator by a registered holding company, the Commission shall not make a finding that such security is not reasonably adapted to the earning power of such company or to the security structure of such company and other companies in the same holding company system, or that the circumstances are such as to constitute the making of such guarantee an improper risk for such company, unless the Commission first finds that the issue or sale of such security, or the making of the guarantee, would have a substantial adverse impact on the financial integrity of the registered holding company system;

" $(4)$ in determining whether to approve (A) the issue or sale of a security by a registered holding company for purposes other than the acquisition of an exempt wholesale generator or (B) other transactions by such registered holding company or by its subsidiaries other than with respect to exempt wholesale generators, the Commission shall not consider the effect of the capitalization or earnings of any subsidiary which is an exempt wholesale generator upon the registered holding company system, unless the approval of the issue or sale or other transaction, together with the effect of such capitalization and earnings, would have a substantial adverse impact on the financial integrity of the registered holding company system;

"(5) the Commission shall make its decision under paragraph (3) to approve or disapprove the issue or sale of a security or the guarantee of a security within 120 days of the filing of a declaration concerning such issue, sale or guarantee; and

"(6) the Commission shall promulgate regulations with respect to the actions which would be considered, for purposes of this subsection, to have a substantial adverse impact on the financial integrity of the registered holding company system; such regulations shall ensure that the action has no adverse impact on any utility subsidiary or its customers, or on the ability of State commissions to protect such subsidiary or customers, and shall take into account the amount and type of capital invested in exempt wholesale generators, the ratio of such capital to the total capital invested in utility operations, the availability of books and records, and the financial and operating experience of the registered holding company and the exempt wholesale generator; the Commission shall promulgate such regulations within 6 months after the enactment of this section, after such 6-month period the Commission shall not approve any actions under paragraph (3), (4) or (5) except in accordance with such issued regulations.

“(I) APPLICATION OF ACT TO OTHER ELIGIBLE FACILITIES.-In the case of any person engaged directly and exclusively in the business of owning or operating (or both owning and operating) all or part of one or more eligible facilities, an advisory letter issued by the Commission staff under this Act after the date of enactment of this section, or an order issued by the Commission under this Act after the date of enactment of this section, shall not be required for the purpose, or have the effect, of exempting such person from treatment as an electric utility company under section 2(a)(3) or exempting such person from any provision of this Act.

"(j) OWNERSHIP OF EXEMPT WHOLESALE GENERATORS AND QUALIFYING FACILITIES.-The ownership by a person of one or more exempt wholesale generators shall not result in such person being considered as being primarily engaged in the generation or sale of electric power within the meaning of sections 3(17)(C)(ii) and 3(18)(B)(ii) of the Federal Power Act (16 U.S.C. 796(17)(C)(ii) and 796(18)(B)(ii)).

"(k) PROTECTION AGAINST ABUSIVE AFFILIATE TRANSACTIONS.-

PROHIBITION.-After the date of enactment of this section, an electric utility company may not enter into a contract to purchase electric energy at wholesale from an exempt wholesale generator if the exempt wholesale generator is an affiliate or associate company of the electric utility company.

“(2) STATE AUTHORITY TO EXEMPT FROM PROHIBITION.-Notwithstanding paragraph (1), an electric utility company may enter into a contract to purchase electric energy at wholesale from an exempt wholesale generator that is an affiliate or associate company of the electric utility company-

"(A) if every State commission having jurisdiction over the retail rates of such electric utility company makes each of the following specific determinations in advance of the electric utility company entering into such contract:

"(i) A determination that such commission has sufficient regulatory authority, resources and access to books and records of the electric utility company and any relevant associate, affiliate or subsidiary company to exercise its duties under this subparagraph. 
“(ii) A determination that the transaction-

"(I) will benefit consumers,

"(II) does not violate any State law (including where applicable, least cost planning),

"(III) would not provide the exempt wholesale generator any unfair competitive advantage by virtue of its affiliation or association with the electric utility company, and

"(IV) is in the public interest; or

"(B) if such electric utility company is not subject to State commission retail rate regulation and the purchased electric energy:

"(i) would not be resold to any affiliate or associate company, or

"(ii) the purchased electric energy would be resold to an affiliate or associate company and every State commission having jurisdiction over the retail rates of such affiliate or associate company makes each of the determinations provided under subparagraph (A), including the determination concerning a State commission's duties.

“(1) RECIPROCAL ARRANGEMENTS PROHIBITED.-Reciprocal arrangements among companies that are not affiliates or associate companies of each other that are entered into in order to avoid the provisions of this section are prohibited.".

\section{SEC. 712. STATE CONSIDERATION OF THE EFFECTS OF POWER PURCHASES ON UTILITY COST OF CAPITAL; CONSIDERATION OF THE EFFECTS OF LEVERAGED CAPITAL STRUCTURES ON THE RELIABILITY OF WHOLESALE POWER SELLERS; AND CONSIDERATION OF ADEQUATE FUEL SUPPLIES.}

Section 111 of the Public Utility Regulatory Policies Act of 1978 (16 U.S.C. 2601 and following) is amended by inserting the following new paragraph after paragraph (9):

"(10) CONSIDERATION OF THE EFFECTS OF WHOLESALE POWER PURCHASES ON UTILITY COST OF CAPITAL; EFFECTS OF LEVERAGED CAPITAL STRUCTURES ON THE RELIABILITY OF WHOLESALE POWER SELLERS; AND ASSURANCE OF ADEQUATE FUEL SUPPLIES.-(A) To the extent that a State regulatory authority requires or allows electric utilities for which it has ratemaking authority to consider the purchase of long-term wholesale power supplies as a means of meeting electric demand, such authority shall perform a general evaluation of:

"(i) the potential for increases or decreases in the costs of capital for such utilities, and any resulting increases or decreases in the retail rates paid by electric consumers, that may result from purchases of long-term wholesale power supplies in lieu of the construction of new generation facilities by such utilities;

"(ii) whether the use by exempt wholesale generators (as defined in section 32 of the Public Utility Holding Company Act of 1935) of capital structures which employ proportionally greater amounts of debt than the capital structures of such utilities 
15 USC 79k note.

16 USC 824.

threatens reliability or provides an unfair advantage for exempt wholesale generators over such utilities;

"(iii) whether to implement procedures for the advance approval or disapproval of the purchase of a particular long-term wholesale power supply; and

"(iv) whether to require as a condition for the approval of the purchase of power that there be reasonable assurances of fuel supply adequacy.

"(B) For purposes of implementing the provisions of this paragraph, any reference contained in this section to the date of enactment of the Public Utility Regulatory Policies Act of 1978 shall be deemed to be a reference to the date of enactment of this paragraph.

"(C) Notwithstanding any other provision of Federal law, nothing in this paragraph shall prevent a State regulatory authority from taking such action, including action with respect to the allowable capital structure of exempt wholesale generators, as such State regulatory authority may determine to be in the public interest as a result of performing evaluations under the standards of subparagraph (A).

"(D) Notwithstanding section 124 and paragraphs (1) and (2) of section 112(a), each State regulatory authority shall consider and make a determination concerning the standards of subparagraph $(\mathrm{A})$ in accordance with the requirements of subsections (a) and (b) of this section, without regard to any proceedings commenced prior to the enactment of this paragraph.

"(E) Notwithstanding subsections (b) and (c) of section 112, each State regulatory authority shall consider and make a determination concerning whether it is appropriate to implement the standards set out in subparagraph (A) not later than one year after the date of enactment of this paragraph.".

\section{SEC. 713. PUBLIC UTILITY HOLDING COMPANIES TO OWN INTERESTS IN COGENERATION FACILITIES.}

Public Law 99-186 (99 Stat. 1180, as amended by Public Law 99-553, 100 Stat. 3087), is amended to read as follows:

"SECTION 1. Notwithstanding section 11(b)(1) of the Public Utility Holding Company Act of 1935, a company registered under said Act, or a subsidiary company of such registered company, may acquire or retain, in any geographic area, an interest in any qualifying cogeneration facilities and qualifying small power production facilities as defined pursuant to the Public Utility Regulatory Policies Act of 1978, and shall qualify for any exemption relating to the Public Utility Holding Company Act of 1935 prescribed pursuant to section 210 of the Public Utility Regulatory Policies Act of 1978.

"SEC. 2. Nothing herein shall be construed to affect the applicability of section 3(17)(C) or section 3(18)(B) of the Federal Power Act or any provision of the Public Utility Holding Company Act of 1935, other than section $11(b)(1)$, to the acquisition or retention of any such interest by any such company.".

\section{SEC. 714. BOOKS AND RECORDS.} thereof:

Section 201 of the Federal Power Act is amended by adding the following new subsection at the end

"(g) BOOKS AND RECORDS.-(1) Upon written order of a State commission, a State commission may examine the books, accounts, memoranda, contracts, and records of-

"(A) an electric utility company subject to its regulatory authority under State law,

"(B) any exempt wholesale generator selling energy at wholesale to such electric utility, and

"(C) any electric utility company, or holding company thereof, which is an associate company or affiliate of an exempt wholesale generator which sells electric energy to an electric utility company referred to in subparagraph (A), wherever located, if such examination is required for the effective discharge of the State commission's regulatory responsibilities affecting the provision of electric service. 
"(2) Where a State commission issues an order pursuant to paragraph (1), the State commission shall not publicly disclose trade secrets or sensitive commercial information.

"(3) Any United States district court located in the State in which the State commission referred to in paragraph (1) is located shall have jurisdiction to enforce compliance with this subsection.

"(4) Nothing in this section shall-

"(A) preempt applicable State law concerning the provision of records and other information; or

"(B) in any way limit rights to obtain records and other information under Federal law, contracts, or otherwise.

"(5) As used in this subsection the terms 'affiliate,' 'associate company', 'electric utility company', 'holding company', 'subsidiary company', and 'exempt wholesale generator' shall have the same meaning as when used in the Public Utility Holding Company Act of 1935.".

\section{SEC. 715. INVESTMENT IN FOREIGN UTILITIES.}

The Public Utility Holding Company Act of 1935 (15 U.S.C. 79 et seq.) is amended by inserting after section 32 the following new section:

\section{"SEC. 33. TREATMENT OF FOREIGN UTILITIES.}

\section{"(a) EXEMPTIONS FOR FOREIGN UTILITY COMPANIES.-}

"(1) IN GENERAL.-A foreign utility company shall be exempt from all of the provisions of this Act, except as otherwise provided under this section, and shall not, for any purpose under this Act, be deemed to be a public utility company under section 2(a)(5), notwithstanding that the foreign utility company may be a subsidiary company, an affiliate, or an associate company of a holding company or of a public utility company.

"(2) STATE COMMISSION CERTIFICATION.-Section (a)(1) shall not apply or be effective unless every State commission having jurisdiction over the retail electric or gas rates of a public utility company that is an associate company or an affiliate of a company otherwise exempted under section (a)(1) (other than a public utility company that is an associate company or an affiliate of a registered holding company) has certified to the Commission that it has the authority and resources to protect ratepayers subject to its jurisdiction and that it intends to exercise its authority. Such certification, upon the filing of a notice by such State commission, may be revised or withdrawn by the State commission prospectively as to any future acquisition. The requirement of State certification shall be deemed satisfied if the relevant State commission had, prior to the date of enactment of this section, on the basis of prescribed conditions of general applicability, determined that ratepayers of a public utility company are adequately insulated from the effects of diversification and the diversification would not impair the ability of the State commission to regulate effectively the operations of such company.

"(3) DEFINITION.-For purposes of this section, the term 'foreign utility company' means any company that-

"(A) owns or operates facilities that are not located in any State and that are used for the generation, transmission, or distribution of electric energy for sale or the distribution at retail of natural or manufactured gas for heat, light, or power, if such company-

"(i) derives no part of its income, directly or indirectly, from the generation, transmission, or distribution of electric energy for sale or the distribution at retail of natural or manufactured gas for heat, light, or power, within the United States; and 
"(ii) neither the company nor any of its subsidiary companies is a public utility company operating in the United States; and

"(B) provides notice to the Commission, in such form as the Commission may prescribe, that such company is a foreign utility company.

"(b) OWNERSHIP OF FOREIGN UTILITY COMPANIES BY EXEMPT HOLDING COMPANIES.-Notwithstanding any provision of this Act except as provided under this section, a holding company that is exempt under section 3 of the Act shall be permitted without condition or limitation under the Act to acquire and maintain an interest in the business of one or more foreign utility companies.

"(c) REGISTERED HOLDING COMPANIES.-

"(1) OWNERSHIP OF FOREIGN UTILITY COMPANIES BY REGISTERED HOLDING COMPANIES.-Notwithstanding any provision of this Act except as otherwise provided under this section, a registered holding company shall be permitted as of the date of enactment of this section (without the need to apply for or receive approval from the Commission) to acquire and hold the securities or an interest in the business, of one or more foreign utility companies. The Commission shall promulgate rules or regulations regarding registered holding companies' acquisition of interests in foreign utility companies which shall provide for the protection of the customers of a public utility company which is an associate company of a foreign utility company and the maintenance of the financial integrity of the registered holding company system.

"(2) ISSUANCE OF SECURITIES.-The issuance of securities by a registered holding company for purposes of financing the acquisition of a foreign utility company, the guarantee of securities of a foreign utility company by a registered holding company, the entering into service, sales, or construction contracts, and the creation or maintenance of any other relationship between a foreign utility company and a registered holding company, its affiliates and associate companies, shall remain subject to the jurisdiction of the Commission under this Act (unless otherwise exempted under this Act, in the case of a transaction with an affiliate or associate company located outside of the United States). Any State commission with jurisdiction over the retail rates of a public utility company which is part of a registered holding company system may make such recommendations to the Commission regarding the registered holding company's relationship to a foreign utility company, and the Commission shall reasonably and fully consider such State recommendation.

"(3) CONSTRUCTION.-Any interest in the business of 1 or more foreign utility companies, or 1 or more companies organized exclusively to own, directly or indirectly, the securities or other interest in a foreign utility company, shall for all purposes of this Act, be considered to be-

"(A) consistent with the operation of a single integrated public utility system, within the meaning of section 11; and

"(B) reasonably incidental, or economically necessary or appropriate, to the operations of an integrated public utility system, within the meaning of section 11 .

"(d) EFFECT ON EXISTING LAW; NO STATE PREEMPTION.-Nothing in this section shall-

"(1) preclude any person from qualifying for or maintaining any exemption otherwise provided for under this Act or the rules, regulations, or orders promulgated or issued under this Act; or

"(2) be deemed or construed to limit the authority of any State (including any State regulatory authority) with respect to-

"(A) any public utility company or holding company subject to such State's jurisdiction; or

"(B) any transaction between any foreign utility company (or any affiliate or associate company thereof) and any public utility company or holding company subject to such State's jurisdiction. 
“(e) REPORTING REQUIREMENTS.-

"(1) FILING OF REPORTS.-A public utility company that is an associate company of a foreign utility company shall file with the Commission such reports (with respect to such foreign utility company) as the Commission may by rules, regulations, or order prescribe as necessary or appropriate in the public interest or for the protection of investors or consumers.

"(2) NOTICE OF ACQUISITIONS.-Not later than 30 days after the consummation of the acquisition of an interest in a foreign utility company by an associate company of a public utility company that is subject to the jurisdiction of a State commission with respect to its retail electric or gas rates or by such public utility company, such associate company or such public utility company, shall provide notice of such acquisition to every State commission having jurisdiction over the retail electric or gas rates of such public utility company, in such form as may be prescribed by the State commission.

" $(f)$ PROHIBITION ON ASSUMPTION OF LIABILITIES.-

"(1) IN GENERAL.-No public utility company that is subject to the jurisdiction of a State commission with respect to its retail electric or gas rates shall issue any security for the purpose of financing the acquisition, or for the purposes of financing the ownership or operation, of a foreign utility company, nor shall any such public utility company assume any obligation or liability as guarantor, endorser, surety, or otherwise in respect of any security of a foreign utility company.

"(2) EXCEPTION FOR HOLDING COMPANIES WHICH ARE PREDOMINANTLY PUBLIC UTILITY COMPANIES.-Subsection $(f)(1)$ shall not apply if:

"(A) the public utility company that is subject to the jurisdiction of a State commission with respect to its retail electric or gas rates is a holding company and is not an affiliate under section 2(a)(11)(B) of another holding company or is not subject to regulation as a holding company and has no affiliate as defined in section 2(a)(11)(A) that is a public utility company subject to the jurisdiction of a State commission with respect to its retail electric or gas rates; and

"(B) each State commission having jurisdiction with respect to the retail electric and gas rates of such public utility company expressly permits such public utility to engage in a transaction otherwise prohibited under section $(f)(1)$; and

"(C) the transaction (aggregated with all other then outstanding transactions exempted under this subsection) does not exceed 5 per centum of the then- outstanding total capitalization of the public utility.

“(g) PROHIBITION ON PLEDGING OR ENCUMBERING UTILITY ASSETS.-No public utility company that is subject to the jurisdiction of a State commission with respect to its retail electric or gas rates shall pledge or encumber any utility assets or utility assets of any subsidiary thereof for the benefit of an associate foreign utility company.".

\section{Subtitle B - Federal Power Act; Interstate Commerce in Electricity}

\section{SEC. 721. AMENDMENTS TO SECTION 211 OF FEDERAL POWER ACT.}

Section 211 of the Federal Power Act (16 U.S.C. 824j) is amended as follows:

(1) The first sentence of subsection (a) is amended to read as follows: "Any electric utility, Federal power marketing agency, or any other person generating electric energy for sale for resale, may apply to the Commission for an order under this subsection requiring a transmitting utility to provide transmission services (including any enlargement of transmission capacity necessary to provide such services) to the applicant.".

(2) In the second sentence of subsection (a), strike "the Commission may" and all that follows and insert "the Commission may issue such order if it finds that such order meets 
the requirements of section 212 , and would otherwise be in the public interest. No order may be issued under this subsection unless the applicant has made a request for transmission services to the transmitting utility that would be the subject of such order at least 60 days prior to its filing of an application for such order.".

(3) Amend subsection (b) to read as follows:

"(b) RELIABILITY OF ELECTRIC SERVICE.-No order may be issued under this section or section 210 if, after giving consideration to consistently applied regional or national reliability standards, guidelines, or criteria, the Commission finds that such order would unreasonably impair the continued reliability of electric systems affected by the order.".

(4) In subsection (c)-

(A) Strike out paragraph (1).

(B) In paragraph (2) strike "which requires the electric" and insert "which requires the transmitting".

(C) Strike out paragraphs (3) and (4).

(5) In subsection (d)-

(A) In the first sentence of paragraph (1), strike "electric" and insert "transmitting" in each place it appears.

(B) In the second sentence of paragraph (1) before "and each affected electric utility," insert "each affected transmitting utility,".

(C) In paragraph (3), strike "electric" and insert "transmitting".

(D) Strike the period in subparagraph (B) of paragraph (1) and insert ", or" and after subparagraph (B) insert the following new subparagraph:

"(C) the ordered transmission services require enlargement of transmission capacity and the transmitting utility subject to the order has failed, after making a good faith effort, to obtain the necessary approvals or property rights under applicable Federal, State, and local laws.".

\section{SEC. 722. TRANSMISSION SERVICES.}

Section 212 of the Federal Power Act is amended as follows:

(1) Strike subsections (a) and (b) and insert the following:

16 USC 824k.

"(a) RATES, CHARGES, TERMS, AND CONDITIONS FOR WHOLESALE TRANSMISSION SERVICES.-An order under section 211 shall require the transmitting utility subject to the order to provide wholesale transmission services at rates, charges, terms, and conditions which permit the recovery by such utility of all the costs incurred in connection with the transmission services and necessary associated services, including, but not limited to, an appropriate share, if any, of legitimate, verifiable and economic costs, including taking into account any benefits to the transmission system of providing the transmission service, and the costs of any enlargement of transmission facilities. Such rates, charges, terms, and conditions shall promote the economically efficient transmission and generation of electricity and shall be just and reasonable, and not unduly discriminatory or preferential. Rates, charges, terms, and conditions for transmission services provided pursuant to an order under section 211 shall ensure that to the extent practicable, costs incurred in providing the wholesale transmission services, and properly allocable to the provision of such services, are recovered from the applicant for such order and not from a transmitting utility's existing wholesale, retail, and transmission customers.".

(2) Subsection (e) is amended to read as follows:

"(e) SAVINGS PROVISIONS.--(1) No provision of section $210,211,214$, or this section shall be treated as requiring any person to utilize the authority of any such section in lieu of any other authority of law. Except as provided in section $210,211,214$, or this section, such sections shall not be construed as limiting or impairing any authority of the Commission under any other provision of law.

"(2) Sections $210,211,213,214$, and this section, shall not be construed to modify, impair, or supersede the antitrust laws. For purposes of this section, the term 'antitrust laws' has the 
meaning given in subsection (a) of the first sentence of the Clayton Act, except that such term includes section 5 of the Federal Trade Commission Act to the extent that such section relates to unfair methods of competition.".

(3) Add the following new subsections at the end thereof:

"(g) PROHIBITION ON ORDERS INCONSISTENT WITH RETAIL MARKETING AREAS.-No order may be issued under this Act which is inconsistent with any State law which governs the retail marketing areas of electric utilities.

"(h) PROHIBITION ON MANDATORY RETAIL WHEELING AND SHAM WHOLESALE TRANSACTIONS.-No order issued under this Act shall be conditioned upon or require the transmission of electric energy:

"(1) directly to an ultimate consumer, or

"(2) to, or for the benefit of, an entity if such electric energy would be sold by such entity directly to an ultimate consumer, unless:

"(A) such entity is a Federal power marketing agency; the Tennessee Valley Authority; a State or any political subdivision of a State (or an agency, authority, or instrumentality of a State or a political subdivision); a corporation or association that has ever received a loan for the purposes of providing electric service from the Administrator of the Rural Electrification Administration under the Rural Electrification Act of 1936; a person having an obligation arising under State or local law (exclusive of an obligation arising solely from a contract entered into by such person) to provide electric service to the public; or any corporation or association which is wholly owned directly or indirectly, by any one or more of the foregoing; and

"(B) such entity was providing electric service to such ultimate consumer on the date of enactment of this subsection or would utilize transmission or distribution facilities that it owns or controls to deliver all such electric energy to such electric consumer.

Nothing in this subsection shall affect any authority of any State or local government under State law concerning the transmission of electric energy directly to an ultimate consumer.".

"(i) LAWS APPLICABLE TO FEDERAL COLUMBIA RIVER TRANSMISSION SYSTEM.-(1) The Commission shall have authority pursuant to section 210 , section 211 , this section, and section 213 to (A) order the Administrator of the Bonneville Power Administration to provide transmission service and (B) establish the terms and conditions of such service. In applying such sections to the Federal Columbia River Transmission System, the Commission shall assure that-

"(i) the provisions of otherwise applicable Federal laws shall continue in full force and effect and shall continue to be applicable to the system; and

"(ii) the rates for the transmission of electric power on the system shall be governed only by such otherwise applicable provisions of law and not by any provision of section 210 , section 211 , this section, or section 213 , except that no rate for the transmission of power on the system shall be unjust unreasonable, or unduly discriminatory or preferential, as determined by the Commission.

"(2) Notwithstanding any other provision of this Act with respect to the procedures for the determination of terms and conditions for transmission service-

"(A) when the Administrator of the Bonneville Power Administration either (i) in response to a written request for specific transmission service terms and conditions does not offer the requested terms and conditions, or (ii) proposes to establish terms and conditions of general applicability for transmission service on the Federal Columbia River Transmission System, then the Administrator may provide opportunity for a hearing and, in so doing, shall-

"(I) give notice in the Federal Register and state in such notice the written explanation of the reasons why the specific terms and conditions for transmission services are not being offered or are being proposed;

"(II) adhere to the procedural requirements of Paragraphs (1) through (3) of section 7(i) of the Pacific Northwest Electric Power Planning and Conservation Act (16 U.S.C. 839(i) (1) through (3)), except that the hearing officer shall, unless the hearing officer becomes unavailable to the agency, make a recommended decision to the Administrator 
that states the hearing officer's findings and conclusions, and the reasons or basis thereof, on all material issues of fact, law, or discretion presented on the record; and

"(III) make a determination, setting forth the reasons for reaching any findings and conclusions which may differ from those of the hearing officer, based on the hearing record, consideration of the hearing officer's recommended decision, section 211 and this section, as amended by the Energy Policy Act of 1992, and the provisions of law as preserved in this section; and

"(B) if application is made to the Commission under section 211 for transmission service under terms and conditions different than those offered by the Administrator, or following the denial of a request for transmission service by the Administrator, and such application is filed within 60 days of the Administrator's final determination and in accordance with Commission procedures, the Commission shall-

"(i) in the event the Administrator has conducted a hearing as herein provided for (I) accord parties to the Administrator's hearing the opportunity to offer for the Commission record materials excluded by the Administrator from the hearing record, (II) accord such parties the opportunity to submit for the Commission record comments on appropriate terms and conditions, (III) afford those parties the opportunity for a hearing if and to the extent that the Commission finds the Administrator's hearing record to be inadequate to support a decision by the Commission, and (IV) establish terms and conditions for or deny transmission service based on the Administrator's hearing record, the Commission record, section 211 and this section, as amended by the Energy Policy Act of 1992, and the provisions of law as preserved in this section, or

"(ii) in the event the Administrator has not conducted a hearing as herein provided for, determine whether to issue an order for transmission service in accordance with section 211 and this section, including providing the opportunity for a hearing.

"(3) Notwithstanding those provisions of section 313(b) of this Act (16 U.S.C. 8251) which designate the court in which review may be obtained, any party to a proceeding concerning transmission service sought to be furnished by the Administrator of the Bonneville Power Administration seeking review of an order issued by the Commission in such proceeding shall obtain a review of such order in the United States Court of Appeals for the Pacific Northwest, as that region is defined by section 3(14) of the Pacific Northwest Electric Power Planning and Conservation Act (16 U.S.C. 839a( 14)).

"(4) To the extent the Administrator of the Bonneville Power Administration cannot be required under section 211, as a result of the Administrator's other statutory mandates, either to (A) provide transmission service to an applicant which the Commission would otherwise order, or (B) provide such service under rates, terms, and conditions which the Commission would otherwise require, the applicant shall not be required to provide similar transmission services to the Administrator or to provide such services under similar rates, terms and conditions.

"(5) The Commission shall not issue any order under section 210 , section 211 , this section, or section 213 requiring the Administrator of the Bonneville Power Administration to provide transmission service if such an order would impair the Administrator's ability to provide such transmission service to the Administrator's power and transmission customers in the Pacific Northwest, as that region is defined in section 3(14) of the Pacific Northwest Electric Power Planning and Conservation Act (16 U.S.C. 839a(14)), as is needed to assure adequate and reliable service to loads in that region.

“(j) EQUTTABILITY WITHIN TERRITORY RESTRICTED ELECTRIC SYSTEMS.-With respect to an electric utility which is prohibited by Federal law from being a source of power supply, either directly or through a distributor of its electric energy, outside an area set forth in such law, no order issued under section 211 may require such electric utility (or a distributor of such electric utility) to provide transmission services to another entity if the electric energy to be transmitted will be consumed within the area set forth in such Federal law, unless the order is in furtherance of a sale of electric energy to that electric utility: Provided, however, That the foregoing provision shall not apply to any area served at retail by an electric transmission system which was such a distributor on the date of enactment of this subsection and which before October 1, 1991, gave its notice of termination under its power supply contract with such electric utility. 
"(k) ERCOT UTILITIES.-

"(1) RATES.-Any order under section 211 requiring provision of transmission services in whole or in part within ERCOT shall provide that any ERCOT utility which is not a public utility and the transmission facilities of which are actually used for such transmission service is entitled to receive compensation based, insofar as practicable and consistent with subsection (a), on the transmission ratemaking methodology used by the Public Utility Commission of Texas.

"(2) DEFINITIONS.-For purposes of this subsection-

"(A) the term 'ERCOT" means the Electric Reliability Council of Texas; and

"(B) the term 'ERCOT utility' means a transmitting utility which is a member of ERCOT.".

“SEC. 723. INFORMATION REQUIREMENTS.

Part II of the Federal Power Act is amended by adding the following new section after section 212:

\section{“SEC. 213. INFORMATION REQUIREMENTS.}

“(a) REQUESTS FOR WHOLESALE TRANSMISSION SERVICES.- Whenever any electric utility, Federal power marketing agency, or any other person generating electric energy for sale for resale makes a good faith request to a transmitting utility to provide wholesale transmission services and requests specific rates and charges, and other terms and conditions, unless the transmitting utility agrees to provide such services at rates, charges, terms and conditions acceptable to such person, the transmitting utility shall, within 60 days of its receipt of the request, or other mutually agreed upon period, provide such person with a detailed written explanation, with specific reference to the facts and circumstances of the request, stating (1) the transmitting utility's basis for the proposed rates, charges, terms and conditions for such services and (2) its analysis of any physical or other constraints affecting the provision of such services.

“(b) TRANSMISSION CAPACITY AND CONSTRUCTS.-Not later than 1 year after the enactment of this section, the Commission shall promulgate a rule requiring that information be submitted annually to the Commission by transmitting utilities which is adequate to inform potential transmission customers, State regulatory authorities, and the public of potentially available transmission capacity and known constraints.".

\section{SEC. 724. SALES BY EXEMPT WHOLESALE GENERATORS.}

Part II of the Federal Power Act is amended by adding the following new section after section 213:

Regulations.

\section{“SEC. 214. SALES BY EXEMPT WHOLESALE GENERATORS.}

"No rate or charge received by an exempt wholesale generator for the sale of electric energy shall be lawful under section $\mathbf{2 0 5}$ if, after notice and opportunity for hearing, the Commission finds that such rate or charge results from the receipt of any undue preference or advantage from an electric utility which is an associate company or an affiliate of the exempt wholesale generator. For purposes of this section, the terms 'associate company' and 'affiliate' shall have the same meaning as provided in section 2(a) of the Public Utility Holding Company Act of 1935.".

16 USC $824 \mathrm{~m}$.

SEC. 725. PENALTIES.

(a) EXISTING PENALTIES NOT APPLICABLE TO TRANSMISSION PROVISIONS.-Sections 315 and 316 of the Federal Power Act are each amended by adding the

16 USC 825n, 
16 USC 8250-1.

16 USC 796.

15 USC 79 note. following at the end thereof:

"(c) This subsection shall not apply in the case of any provision of section $211,212,213$, or 214 or any rule or order issued under any such provision.".

(b) PENALTIES APPLICABLE TO TRANSMISSION PROVISIONS.-Title III of the Federal Power Act is amended by inserting the following new section after section 316 :

“SEC. 316A. ENFORCEMENT OF CERTAIN PROVISIONS.

“(a) VIOLATIONS.-It shall be unlawful for any person to violate any provision of section 211, 212, 213 , or 214 or any rule or order issued under any such provision.

"(b) CIVIL PENALTIES.-Any person who violates any provision of section 211, 212, 213, or 214 or any provision of any rule or order thereunder shall be subject to a civil penalty of not more than $\$ 10,000$ for each day that such violation continues. Such penalty shall be assessed by the Commission, after notice and opportunity for public hearing, in accordance with the same provisions as are applicable under section 31(d) in the case of civil penalties assessed under section 31. In determining the amount of a proposed penalty, the Commission shall take into consideration the seriousness of the violation and the efforts of such person to remedy the violation in a timely manner.".

\section{SEC. 726. DEFINITIONS.}

(a) ADDITIONAL DEFINITIONS.-Section 3 of the Federal Power Act is amended by adding the following at the end thereof:

"(23) TRANSMITTING UTILITY.-The term 'transmitting utility' means any electric utility, qualifying cogeneration facility, qualifying small power production facility, or Federal power marketing agency which owns or operates electric power transmission facilities which are used for the sale of electric energy at wholesale.

"(24) WHOLESALE TRANSMISSION SERVICES.-The term 'wholesale transmission services' means the transmission of electric energy sold, or to be sold, at wholesale in interstate commerce.

“(25) EXEMPT WHOLESALE GENERATOR.-The term 'exempt wholesale generator' shall have the meaning provided by section 32 of the Public Utility Holding Company Act of 1935.".

(b) CLARIFICATION OF TERMS.-Section 3(22) of the Federal Power Act is amended by inserting "(including any municipality)" after "State agency".

\section{Subtitle C-State and Local Authorities}

\section{SEC. 731. STATE AUTHORITIES.}

Nothing in this title or in any amendment made by this title shall be construed as affecting or intending to affect, or in any way to interfere with, the authority of any State or local government relating to environmental protection or the siting of facilities. 

Appendix G

Selected Provisions of the Federal Power Act Referenced in the FERC Mega-NOPR 



\section{Appendix G}

\section{Selected Provisions of the Federal Power Act Referenced in the FERC Mega-NOPR}

\section{RATE AND CHARGES; SCHEDULES; SUSPENSION OF NEW RATES}

SEC. 205. (a) All rates and charges made, demanded, or received by any public utility for or in connection with the transmission or sale of electric energy subject to the jurisdiction of the Commission, and all rules and regulations affecting or pertaining to such rates or charges shall be just and reasonable, and any such rate or charge that is not just and reasonable is hereby declared to be unlawful.

(b) No public utility shall, with respect to any transmission or sale subject to the jurisdiction of the Commission, (1) make or grant any undue preference or advantage to any person or subject any person to any undue prejudice or disadvantage, or (2) maintain any unreasonable difference in rates, charges, service, facilities, or in any other respect, either as between localities or as between classes of service.

(c) Under such rules and regulations as the Commission may prescribe, every public utility shall file with the Commission, within such time and in such form as the Commission may designate, and shall keep open in convenient form and place for public inspection schedules showing all rates and charges for any transmission or sale subject to the jurisdiction of the Commission, and the classification, practices, and regulations affecting such rates and charges, together with all contracts which in any manner affect or relate to such rates, charges, classifications, and services.

(d) Unless the Commission otherwise orders, no change shall be made by any public utility in any such rates, charges, classification, or service, or in any rule, regulation, or contract relating thereto, except after sixty days' notice to the Commission and to the public. Such notice shall be given by filing with the Commission and keeping open for public inspection new schedules stating plainly the change or changes to be made in the schedule or schedules then in force and the time when the change or changes will go into effect. The Commission, for good cause shown, may allow changes to take effect without requiring the sixty days' notice herein provided for by an order specifying the changes so to be made and the time when they shall take effect and the manner in which they shall be filed and published.

(e) Whenever any such new schedule is filed the Commission shall have authority, either upon complaint or upon its own initiative without complaint at once, and, if it so orders, without answer or formal pleading by the public utility, but upon reasonable notice to enter upon a hearing concerning the lawfulness of such rate, charge, classification, or service; and, pending such hearing and the decision thereon the Commission, upon filing with such schedules and delivering to the public utility affected thereby a statement in writing of its reasons for such suspension, may suspend the operation of such schedule and defer the use of such rate, charge, classification, or service, but not for a longer period than five months beyond the time when it would otherwise go into effect; and after full hearings, either completed before or after the rate, charge, classification, or service goes into effect, the Commission may make such orders with reference thereto as would be proper in a proceeding initiated after it had become effective. If the proceeding has not been concluded and an order made at the expiration of such five months, the proposed change of rate, charge, classification, or service shall go into effect at the end of such period, but in case of a proposed increased rate or charge, the Commission may by order require the interested public utility or public utilities to keep accurate account in detail of all amounts received by reason of such increase, specifying by whom and in whose behalf such amounts are paid, and upon completion of the hearing and decision may by further order require such public utility or public utilities to refund with interest, to the persons in whose behalf such amounts were paid, such portion of such increased rates or charges as by its decision shall be found not justified. At any hearing involving a rate or charge sought to be increased, the burden of proof to show that the increased rate or charge is just and reasonable shall be upon the public utility, and the Commission shall give to the hearing and decision of such questions preference over other questions pending before it and decide the same as speedily as possible.

(f)(1) Not later than 2 years after the date of the enactment of this subsection and not less often than every 4 years thereafter the Commission shall make a thorough review of automatic adjustment clauses in public utility rate schedules to examine-

(A) whether or not each such clause effectively provides incentives for efficient use of resources (including economical purchase and use of fuel and electric energy), and

(B) whether any such clause reflects any costs other than costs which are-

(i) subject to periodic fluctuations, and

(ii) not susceptible to precise determinations in rate cases prior to the time such costs are incurred.

Such review may take place in individual rate proceedings or in generic or other separate proceedings applicable to one or more utilities. 
(2) Not less frequently than every 2 years, in rate proceedings or in generic or other separate proceedings, the Commission shall review, with respect to each public utility, practices under any automatic adjustment clauses of such utility to insure efficient use of resources (including economical purchase and use of fuel and electric energy) under such clauses.

(3) The Commission may, on its own motion or upon complaint, after an opportunity for an evidentiary hearing, order a public utility to-

(A) modify the terms and provisions of any automatic adjustment clause, or

(B) cease any practice in connection with the clause, if such clause or practice does not result in the economical purchase and use of fuel, electric energy, or other items, the cost of which is included in any rate schedule under an automatic adjustment clause.

(4) As used in this subsection, the term "automatic adjustment clause" means a provision of a rate schedule which provides for increases or decreases (or both), without prior hearing, in rates reflecting increases or decreases (or both) in costs incurred by an electric utility. Such term does not include any rate which takes effect subject to refund and subject to a later determination of the appropriate amount of such rate.

(16 U.S.C. $824 \mathrm{~d}$ )

\section{FIXING RATES AND CHARGES; DETERMINATION OF COST OF PRODUCTION OR TRANSPORTATION}

SEC. 206. (a) Whenever the Commission, after a hearing had upon its own motion or upon complaint, shall find that any rate, charges, or classification demanded, observed, charged, or collected by any public utility for any transmission or sale subject to the jurisdiction of the Commission, or that any rule, regulation, practice, or contract affecting such rate, charge, or classification is unjust, unreasonable, unduly discriminatory or preferential, the Commission shall determine the just and reasonable rate, charge, classification, rule, regulation, practice, or contract to be thereafter observed and in force, and shall fix the same by order.

(b) Whenever the Commission institutes a proceeding under this section, the Commission shall establish a refund effective date. In the case of a proceeding instituted on complaint, the refund effective date shall not be earlier than the date 60 days after the filing of such complaint nor later than 5 months after the expiration of such 60-day period. In the case of a proceeding instituted by the Commission on its own motion, the refund effective date shall not be earlier than the date 60 days after the publication by the Commission of notice of its intention to initiate such proceeding nor later than 5 months after the expiration of such 60 -day period. Upon institution of a proceeding under this section, the Commission shall give to the decision of such proceeding the same preference as provided under section 205 of this Act and otherwise act as speedily as possible. If no final decision is rendered by the refund effective date or by the conclusion of the 180-day period commencing upon initiation of a proceeding pursuant to this section, whichever is earlier, the Commission shall state the reasons why it has failed to do so and shall state its best estimate as to when it reasonably expects to make such decision. In any proceeding under this section, the burden of proof to show that any rate, charge, classification, rule, regulation, practice, or contract is unjust, unreasonable, unduly discriminatory, or preferential shall be upon the Commission or the complainant. At the conclusion of any proceeding under this section, the Commission may order the public utility to make refunds of any amounts paid, for the period subsequent to the refund effective date through a date fifteen months after such refund effective date, in excess of those which would have been paid under the just and reasonable rate, charge, classification, rule, regulation, practice, or contract which the Commission orders to be thereafter observed and in force: Provided, That if the proceeding is not concluded within fifteen months after the refund effective date and if the Commission determines at the conclusion of the proceeding that the proceeding was not resolved within the fifteen-month period primarily because of dilatory behavior by the public utility, the Commission may order refunds of any or all amounts paid for the period subsequent to the refund effective date and prior to the conclusion of the proceeding. The refunds shall be made, with interest, to those persons who have paid those rates or charges which are the subject of the proceeding.

(c) Notwithstanding subsection (b), in a proceeding commenced under this section involving two or more electric utility companies of a registered holding company, refunds which might otherwise be payable under subsection (b) shall not be ordered to the extent that such refunds would result from any portion of a Commission order that (1) requires a decrease in system production or transmission costs to be paid by one or more of such electric companies; and (2) is based upon a determination that the amount of such decrease should be paid through an increase in the costs to be paid by other electric utility companies of such registered holding company: Provided, That refunds, in whole or in part, may be ordered by the Commission if it determines that the registered holding company would not experience any reduction in revenues which results from an inability of an electric utility company of the holding company to recover such increase in costs for the period between the refund effective date and the effective date of the Commission's order. For purposes of this subsection, the terms "electric utility companies" and "registered holding company" shall have the same meanings as provided in the Public Utility Holding Company Act of 1935, as amended.

(d) The Commission upon its own motion, or upon the request of any State commission whenever it can do so without prejudice to the efficient and proper conduct of its affairs, may investigate and determine the cost of the production or transmission of electric energy by means of facilities under the jurisdiction of the Commission in cases where the Commission has no authority to establish a rate governing the sale of such energy.

(16 U.S.C. $824 \mathrm{i}$ ) 


\section{CERTAIN WHEELING AUTHORITY}

SEC. 211. (a) Any electric utility, Federal power marketing agency, or any other person generating electric energy for sale for resale, may apply to the Commission for an order under this subsection requiring a transmitting utility to provide transmission services (including any enlargement of transmission capacity necessary to provide such services) to the applicant. Upon receipt of such application, after public notice and notice to each affected State regulatory authority, each affected electric utility, and each affected Federal power marketing agency, and after affording an opportunity for an evidentiary hearing, the Commission may issue such order if it finds that such order meets the requirements of section 212, and would otherwise be in the public interest. No order may be issued under this subsection unless the applicant has made a request for transmission services to the transmitting utility that would be the subject of such order at least 60 days prior to its filing of an application for such order.

(b) RELIABILITY OF ELECTRIC SERVICE.-No order may be issued under this section or section 210 if, after giving consideration to consistently applied regional or national reliability standards, guidelines, or criteria, the Commission finds that such order would unreasonably impair the continued reliability of electric systems affected by the order.

(c) (2) ${ }^{285}$ No order may be issued under subsection (a) or (b) which requires the transmitting utility subject to the order to transmit, during any period, an amount of electric energy which replaces any amount of electric energy-

(A) required to be provided to such applicant pursuant to a contract during such period, or

(B) currently provided to the applicant by the utility subject to the order pursuant to a rate schedule on file during such period with the Commission: Provided, That nothing in this subparagraph shall prevent an application for an order hereunder to be filed prior to termination of modification of an existing rate schedule: Provided, That such order shall not become effective until termination of such rate schedule or the modification becomes effective.

(d)(1) Any transmitting utility ordered under subsection (a) or (b) to provide transmission services may apply to the Commission for an order permitting such transmitting utility to cease providing all, or any portion of, such services. After public notice, notice to each affected State regulatory authority, each affected Federal power marketing agency, each affected transmitting utility, and each affected electric utility, and after an opportunity for an evidentiary hearing, the Commission shall issue an order terminating or modifying the order issued under subsection (a) or (b), if the electric utility providing such transmission services has demonstrated, and the Commission has found, that-

(A) due to changed circumstances, the requirements applicable, under this section and section 212 , to the issuance of an order under subsection (a) or (b) are no longer met, or

(B) any transmission capacity of the utility providing transmission services under such order which was, at the time such order was issued, in excess of the capacity necessary to serve its own customers is no longer in excess of the capacity necessary for such purposes, or

(C) the ordered transmission services require enlargement of transmission capacity and the transmitting utility subject to the order has failed, after making a good faith effort, to obtain the necessary approvals or property rights under applicable Federal, State, and local laws.

No order shall be issued under this subsection pursuant to a finding under subparagraph $(A)$ unless the Commission finds that such order is in the public interest.

(2) Any order issued under this subsection terminating or modifying an order issued under subsection (a) or (b) shall-

(A) provide for any appropriate compensation, and

(B) provide the affected electric utilities adequate opportunity and time to-

(i) make suitable alternative arrangements for any transmission services terminated or modified, and

(ii) insure that the interests of ratepayers of such utilities are adequately protected.

(3) No order may be issued under this subsection terminating or modifying any order issued under subsection (a) or (b) if the order under subsection (a) or (b) includes terms and conditions agreed among by the parties which-

(A) fix a period during which transmission services are to be provided under the order under subsection (a) or (b), or

(B) otherwise provide procedures or methods for terminating or modifying such order (including, if appropriate, the return of the transmission capacity when necessary to take into account an increase, after the issuance of such order, in the needs of the transmitting utility subject to such order for transmission capacity).

(e) As used in this section, the term "facilities" means only facilities used for the generation or transmission of electric energy. (16 U.S.C. 824j)

\section{PROVISIONS REGARDING CERTAIN ORDERS REQUIRING INTERCONNECTION OR WHEELING}

SEC. 212. (a) RATES, CHARGES, TERMS, AND CONDITIONS FOR WHOLESALE TRANSMISSION SERVICES.-An order under section 211 shall require the transmitting utility subject to the order to provide wholesale transmission services at rates, charges, terms, and conditions which permit the recovery by such utility of all the costs incurred in connection with the transmission services and necessary associated services, including, but not limited to, an appropriate share, if any, of legitimate, verifiable and economic costs, including taking into account any benefits to the transmission system of providing the transmission service, and the costs of any

${ }^{285}$ Section 721(4) of P.L. 102-486 struck paragraphs (1), (3), and (4) without redesgnating paragraph (2). 
enlargement of transmission facilities. Such rates, charges, terms, and conditions shall promote the economically efficient transmission and generation of electricity and shall be just and reasonable, and not unduly discriminatory or preferential. Rates, charges, terms, and conditions for transmission services provided pursuant to an order under section 211 shall ensure that, to the extent practicable, costs incurred in providing the wholesale transmission services, and properly allocable to the provision of such services, are recovered from the applicant for such order and not from a transmitting utility's existing wholesale, retail, and transmission customers. [Subsection (b) repealed]

(c)(1) Before issuing an order under section 210 of subsection (a) or (b) of section 211, the Commission shall issue a proposed order and set a reasonable time for parties to the proposed interconnection or transmission order to agree to terms and conditions under which such order is to be carried out, including the apportionment of costs between them and the compensation or reimbursement reasonably due to any of them. Such proposed order shall not be reviewable or enforceable in any court. The time set for such parties to agree to such terms and conditions may be shortened if the Commission determines that delay would jeopardize the attainment of the purposes of any proposed order. Any terms and conditions agreed to by the parties shall be subject to the approval of the Commission.

(2)(A) If the parties agree as provided in paragraph (1) within the time set by the Commission and the Commission approves such agreement, the terms and conditions shall be included in the final order. In the case of an order under section 210 , if the parties fail to agree within the time set by the Commission or if the Commission does not approve any such agreement, the Commission shall prescribe such terms and conditions and include such terms and conditions in the final order.

(B) In the case of any order applied for under section 211, if the parties fail to agree within the time set by the Commission, the Commission shall prescribe such terms and conditions in the final order.

(d) If the Commission does not issue any order applied for under section 210 or 211, the Commission shall, by order, deny such application and state the reasons for such denial.

(e) SAVINGS PROVISIONS.-(1) No provision of section 210,211, 214, or this section shall be treated as requiring any person to utilize the authority of any such section in lieu of any other authority of law. Except as provided in section $210,211,214$, or this section, such sections shall not be construed as limiting or impairing any authority of the Commission under any other provision of law.

(2) Sections 210,211,213,214, and this section, shall not be construed to modify, impair, or supersede the antitrust laws. For purposes of this section, the term "antitrust laws" has the meaning given in subsection (a) of the first sentence of the Clayton Act, except that such term includes section 5 of the Federal Trade Commission Act to the extent that such section relates to unfair methods of competition.

(f)(1) No order under section 210 or 211 requiring the Tennessee Valley Authority (hereinafter in this subsection referred to as the "TVA") to take any action shall take effect for 60 days following the date of issuance of the order. Within 60 days following the issuance by the Commission of any order under section 210 or of section 211 requiring the TVA to enter into any contract for the sale or delivery of power, the Commission may on its own motion initiate, or upon petition of any aggrieved person shall initiate, an evidentiary hearing to determine whether or not such sale or delivery would result in violation of the third sentence of section $15 \mathrm{~d}(\mathrm{a})$ of the Tennessee Valley Authority Act of 1933 (16 U.S.C. 831n -4), hereinafter in this subsection referred to as the TVA Act.

(2) Upon initiation of any evidentiary hearing under paragraph (1), the Commission shall give notice thereof to any applicant who applied for and obtained the order from the Commission, to any electric utility or other entity subject to such order, and to the public, and shall promptly make the determination referred to in paragraph (1). Upon initiation of such hearing, the Commission shall stay the effectiveness of the order under section 210 or 211 until whichever of the following dates is applicable-

(A) the date on which there is a final determination (including any judicial review thereof under paragraph (3)) that

no such violation would result from such order, or

(B) the date on which a specific authorization of the Congress (within the meaning of the third sentence of section $15 \mathrm{~d}(\mathrm{a})$ of the TVA Act) takes effect.

(3) Any determination under paragraph (1) shall be reviewable only in the appropriate court of the United States upon petition filed by any aggrieved person or municipality within 60 days after such determination, and such court shall have jurisdiction to grant appropriate relief. Any applicant who applied for and obtained the order under section 210 or 211 , and any electric utility or other entity subject to such order shall have the right to intervene in and such proceeding in such court. Except for review by such court (and any appeal or other review by an appellate court of the United States), no court shall have jurisdiction to consider any action brought by any person to enjoin the carrying out of any order of the Commission under section 210 or section 211 requiring the TVA to take any action on the grounds that such action requires a specific authorization of the Congress pursuant to the third sentence of section $15 \mathrm{~d}(\mathrm{a})$ of the TVA Act.

(g) PROHIBITION ON ORDERS INCONSISTENT WITH RETAIL MARKETING AREAS.-No order may be issued under this Act which is inconsistent with any State law which governs the retail marketing areas of electric utilities.

(h) PROHIBITION ON MANDATORY RETAIL WHEELING AND SHAM WHOLESALE TRANSACTIONS.-No order issued under this Act shall be conditioned upon or require the transmission of electric energy:

(1) directly to an ultimate consumer, or

(2) to, or for the benefit of, an entity if such electric energy would be sold by such entity directly to an ultimate consumer, unless:

(A) such entity is a Federal power marketing agency; the Tennessee Valley Authority; a State or any political subdivision of a State (or an agency, authority, or instrumentality of a State or a political subdivision); a corporation or association that has ever received a loan for the purposes of providing electric service from the Administrator of the Rural Electrification Administration under the Rural Electrification Act of 1936; a person having an obligation arising 
under State or local law (exclusive of an obligation arising solely from a contract entered into by such person) to provide electric service to the public; or any corporation or association which is wholly owned, directly or indirectly, by any one or more of the foregoing; and

(B) such entity was providing electric service to such ultimate consumer on the date of enactment of this subsection or would utilize transmission or distribution facilities that it owns or controls to deliver all such electric energy to such electric consumer.

Nothing in this subsection shall affect any authority of any State or local government under State law concerning the transmission of electric energy directly to an ultimate consumer.

(i) LAWS APPLICABLE TO FEDERAL COLUMBIA RIVER TRANSMISSION SYSTEM.-(41) The Commission shall have authority pursuant to section 210, section 211, this section, and section 213 to (A) order the Administrator of the Bonneville Power Administration to provide transmission service and (B) establish the terms and conditions of such service. In applying such sections to the Federal Columbia River Transmission System, the Commission shall assure that-

(i) the provisions of otherwise applicable Federal laws shall continue in full force and effect and shall continue to be applicable to the system; and

(ii) the rates for the transmission of electric power on the system shall be governed only by such otherwise applicable provisions of law and not by any provision of section 210 , section 211 , this section, or section 213 , except that no rate for the transmission of power on the system shall be unjust, unreasonable, or unduly discriminatory or preferential, as determined by the Commission.

(2) Notwithstanding any other provision of this Act with respect to the procedures for the determination of terms and conditions for transmission service-

(A) when the Administrator of the Bonneville Power Administration either (i) in response to a written request for specific transmission service terms and conditions does not offer the requested terms and conditions, or (ii) proposes to establish terms and conditions of general applicability for transmission service on the Federal Columbia River Transmission System, then the Administrator may provide opportunity for a hearing and, in so doing, shall-

(I) give notice in the Federal Register and state in such notice the written explanation of the reasons why the specific terms and conditions for transmission services are not being offered or are being proposed;

(II) adhere to the procedural requirements of paragraphs (1) through (3) of section 7(i) of the Pacific Northwest Electric Power Planning and Conservation Act (16 U.S.C. 839(i) (1) through (3)), except that the hearing officer shall, unless the hearing officer becomes unavailable to the agency, make a recommended decision to the Administrator that states the hearing officer's findings and conclusions, and the reasons or basis thereof, on all material issues of fact, law, or discretion presented on the record; and

(III) make a determination, setting forth the reasons for reaching any findings and conclusions which may differ from those of the hearing officer, based on the hearing record, consideration of the hearing officer's recommended decision, section 211 and this section, as amended by the Energy Policy Act of 1992, and the provisions of law as preserved in this section; and

(B) if application is made to the Commission under section 211 for transmission service under terms and conditions different than those offered by the Administrator, or following the denial of a request for transmission service by the Administrator, and such application is filed within 60 days of the Administrator's final determination and in accordance with Commission procedures, the Commission shall-

(i) in the event the Administrator has conducted a hearing as herein provided for (I) accord parties to the Administrator's hearing the opportunity to offer for the Commission record materials excluded by the Administrator from the hearing record, (II) accord such parties the opportunity to submit for the Commission record comments on appropriate terms and conditions, (III) afford those parties the opportunity for a hearing if and to the extent that the Commission finds the Administrator's hearing record to be inadequate to support a decision by the Commission, and (IV) establish terms and conditions for or deny transmission service based on the Administrator's hearing record, the Commission record, section 211 and this section, as amended by the Energy Policy Act of 1992, and the provisions of law as preserved in this section, or

(ii) in the event the Administrator has not conducted a hearing as herein provided for, determine whether to issue an order for transmission service in accordance with section 211 and this section, including providing the opportunity for a hearing.

(3) Notwithstanding those provisions of section 313(b) of this Act (16 U.S.C. 825I) which designate the court in which review may be obtained, any party to a proceeding concerning transmission service sought to be furnished by the Administrator of the Bonneville Power Administration seeking review of an order issued by the Commission in such proceeding shall obtain a review of such order in the United States Court of Appeals for the Pacific Northwest, as that region is defined by section 3(14) of the Pacific Northwest Electric Power Planning and Conservation Act (16 U.S.C. 839a(14)).

(4) To the extent the Administrator of the Bonneville Power Administration cannot be required under section 211, as a result of the Administrator's other statutory mandates, either to (A) provide transmission service to an applicant which the Commission would otherwise order, or (B) provide such service under rates, terms, and conditions which the Commission would otherwise require, the applicant shall not be required to provide similar transmission services to the Administrator or to provide such services under similar rates, terms, and conditions.

(5) The Commission shall not issue any order under section 210, section 211, this section, or section 213 requiring the Administrator of the Bonneville Power Administration to provide transmission service if such an order would impair the 
Administrator's ability to provide such transmission service to the Administrator's power and transmission customers in the Pacific Northwest, as that region is defined in section 3(14) of the Pacific Northwest Electric Power Planning and Conservation Act (16 U.S.C. $839 \mathrm{a}(14))$, as is needed to assure adequate and reliable service to loads in that region.

(j) EQUITABILITY WITHIN TERRITORY RESTRICTED ELECTRIC SYSTEMS.-With respect to an electric utility which is prohibited by Federal law from being a source of power supply, either directly or through a distributor of its electric energy, outside an area set forth in such law, no order issued under section 211 may require such electric utility (or a distributor of such electric utility) to provide transmission services to another entity if the electric energy to be transmitted will be consumed within the area set forth in such Federal law, unless the order is in furtherance of a sale of electric energy to that electric utility: Provided, however, That the foregoing provision shall not apply to any area served at retail by an electric transmission system which was such a distributor on the date of enactment of this subsection and which before October 1, 1991, gave its notice of termination under its power supply contract with such electric utility.

(k) ERCOT UTILITIES.-

(1) RATES.-Any order under section 211 requiring provision of transmission services in whole or in part within ERCOT shall provide that any ERCOT utility which is not a public utility and the transmission facilities of which are actually used for such transmission service is entitled to receive compensation based, insofar as practicable and consistent with subsection (a), on the transmission ratemaking methodology used by the Public Utility Commission of Texas.

(2) DEFINITIONS.-For purposes of this subsection-

(16 U.S.C. $824 k$ )

(A) the term "ERCOT" means the Electric Reliability Council of Texas; and

(B) the term "ERCOT utility" means a transmitting utility which is a member of ERCOT. 